Prepared in cooperation with the U.S. Fish and Wildlife Service

Hydrologic and Landscape Database for the Cache and White River National Wildlife Refuges and Contributing Watersheds in Arkansas, Missouri, and Oklahoma
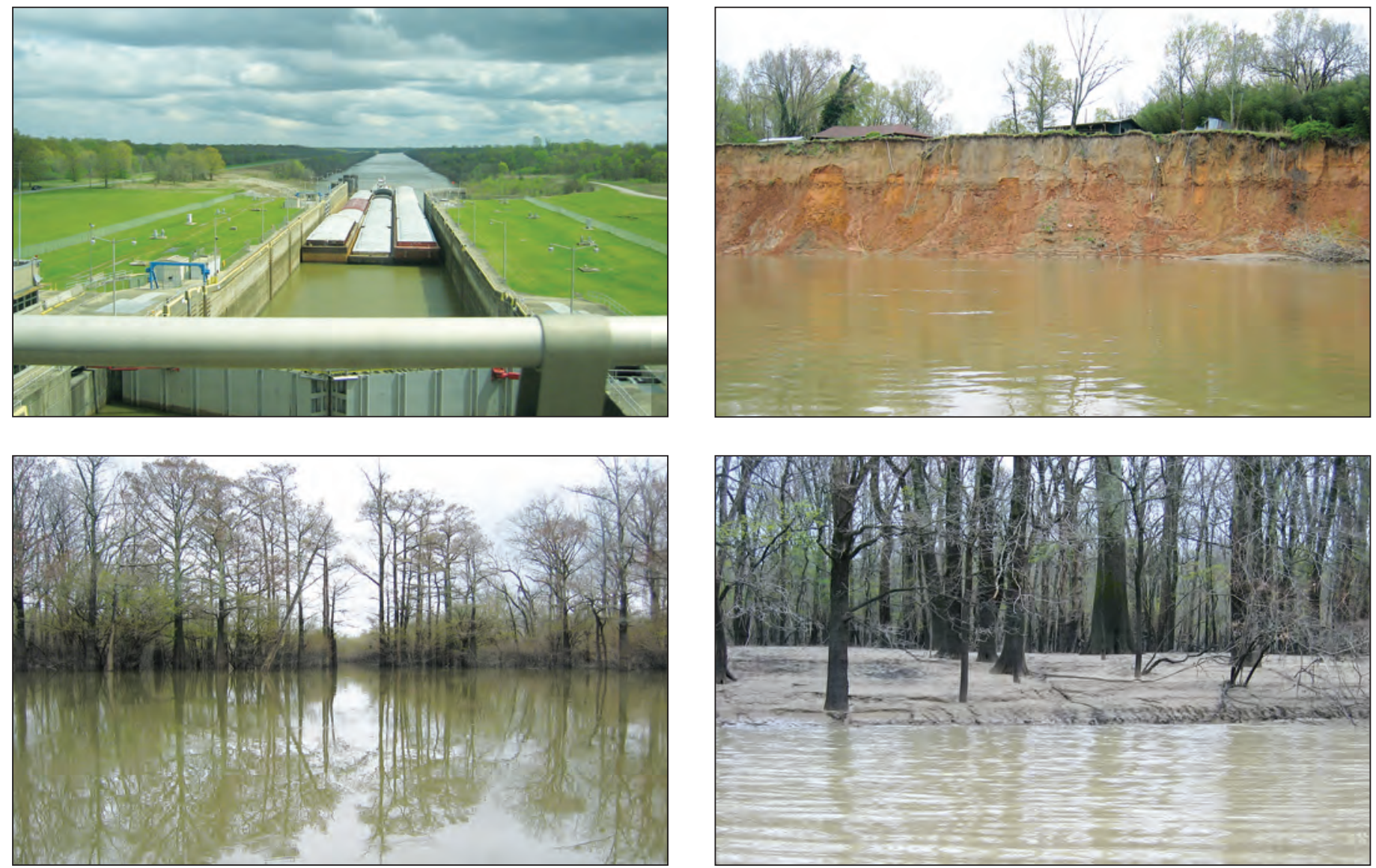

Open-File Report 2012-1026 


\section{Cover photographs, taken March 25, 2009.}

Upper left—Navigation locks on the McClellan-Kerr Arkansas Post Canal, connecting the lower Arkansas and lower White Rivers.

Upper right—Eroding bank margin, lower White River.

Lower left-Bald cypress, White River National Wildlife Refuge.

Lower right—Overbank sand deposits from seasonal flooding, lower White River, White River National Wildlife Refuge. 


\section{Hydrologic and Landscape Database for the Cache and White River National Wildlife Refuges and Contributing Watersheds in Arkansas, Missouri, and Oklahoma}

By Gary R. Buell, Loren L. Wehmeyer, and Daniel L. Calhoun

Prepared in cooperation with the U.S. Fish and Wildlife Service

Open-File Report 2012-1026 


\section{U.S. Department of the Interior \\ KEN SALAZAR, Secretary \\ U.S. Geological Survey \\ Marcia K. McNutt, Director}

\section{U.S. Geological Survey, Reston, Virginia: 2012}

For more information on the USGS - the Federal source for science about the Earth, its natural and living resources, natural hazards, and the environment, visit http://www.usgs.gov or call 1-888-ASK-USGS

For an overview of USGS information products, including maps, imagery, and publications, visit $h$ ttp://www.usgs.gov/pubprod

To order this and other USGS information products, visit http://store.usgs.gov

Any use of trade, product, or firm names is for descriptive purposes only and does not imply endorsement by the U.S. Government.

Although this report is in the public domain, permission must be secured from the individual copyright owners to reproduce any copyrighted materials contained within this report.

Suggested citation:

Buell, G.R., Wehmeyer, L.L., and Calhoun, D.L., 2012, Hydrologic and landscape database for the Cache and White River National Wildlife Refuges and contributing watersheds in Arkansas, Missouri, and Oklahoma: U.S. Geological Survey Open-File Report 2012-1026, 79 p., available online at http://pubs.usgs.gov/of/2012/1026/. 


\section{Contents}

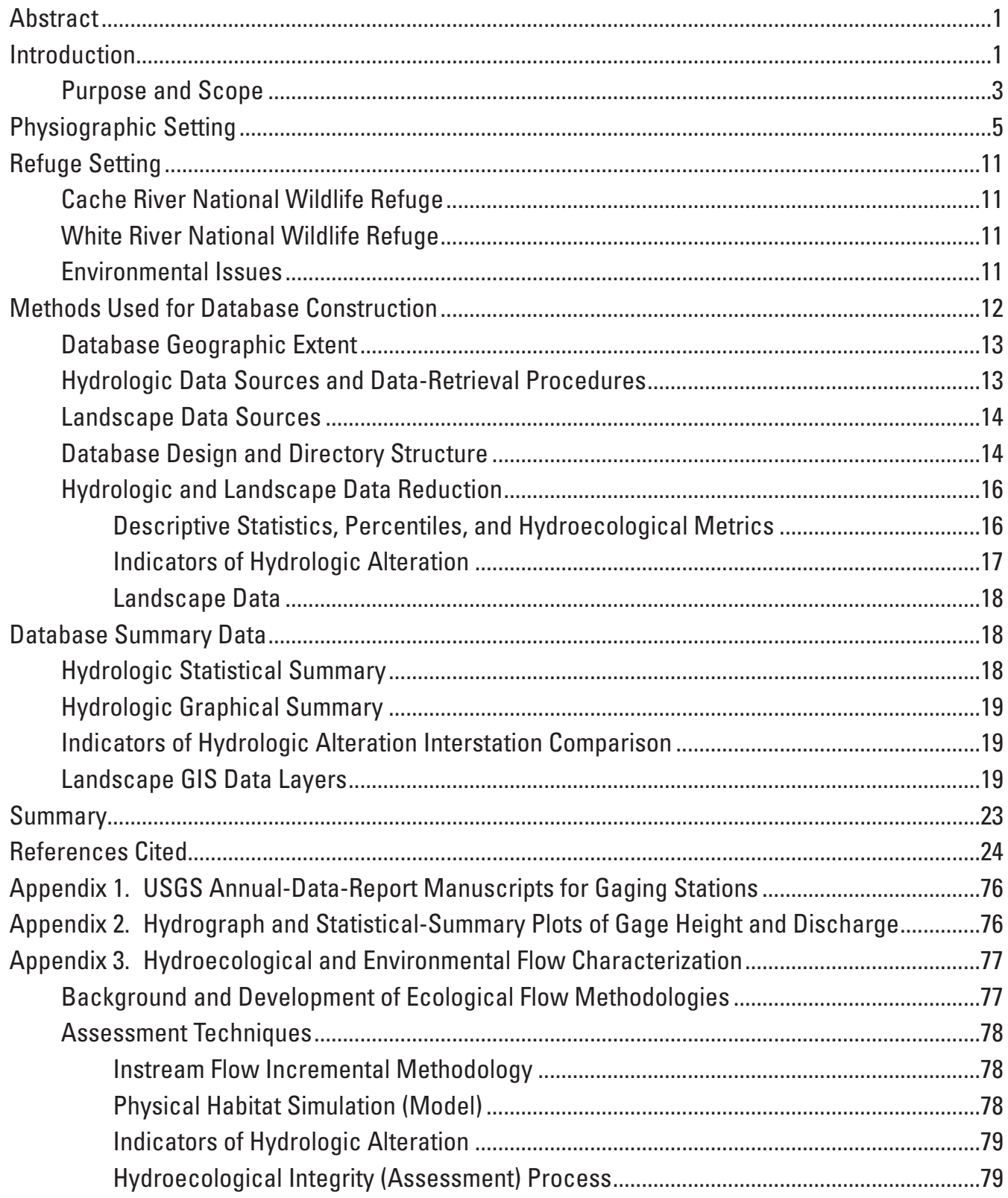




\section{Figures}

1. Maps showing location of the Cache and White River National Wildlife Refuges and vicinity with major contributing watersheds, waterways, gaging stations, the Cache and Grand Prairie Critical Groundwater Areas, Crowleys Ridge (Bluff Hills Level IV ecoregion), and Grand Prairie Level IV ecoregion.

2. Map showing location of Cache and White River National Wildlife Refuges, Lower Mississippi-St. Francis (0802), Upper White (1101), and Lower Arkansas (1111) hydrologic subregions and cataloguing units, lines of equal mean-annual runoff for the period 1951-1980, and U.S. Environmental Protection Agency Level III ecoregions

$3 A-3 D$. Maps showing percentages of U.S. Department of Agriculture hydrologic soil group (HSG) shown by hydrologic cataloging unit in the Lower MississippiSt. Francis (0802), Upper White (1101), and Lower Arkansas (1111) hydrologic subregions-

3A. HSG A; soils in HSG A have low runoff potential: water is freely transmitted through the soil.

3B. HSG B; soils in HSG B have moderately-low runoff potential: water transmission through the soil is unimpeded.

3C. HSG C; soils in HSG C have moderately-high runoff potential: water transmission through the soil is somewhat restricted

3D. HSG D; soils in HSG D have high runoff potential: water transmission through the soil is restricted or very restricted.

4. Graph showing periods of record for mean-daily gage-height data used in Indicators of Hydrologic Alteration analyses for gaging stations in the contributing watersheds and vicinity of the Cache and White River National Wildlife Refuges, Arkansas, Missouri, and Oklahoma

5. Graph showing periods of record for mean-daily discharge data used in Indicators of Hydrologic Alteration analyses for gaging stations in the contributing watersheds and vicinity of the Cache and White River National Wildlife Refuges, Arkansas, Missouri, and Oklahoma...

6. Map showing land cover for 1992 for the Lower Mississippi-St. Francis (0802), Upper White (1101), and Lower Arkansas (1111) hydrologic subregions and cataloging units.

7. Map showing land cover for 2001 for the Lower Mississippi-St. Francis (0802), Upper White (1101), and Lower Arkansas (1111) hydrologic subregions and cataloging units

8. Map showing land-cover-change for the period from 1992 to 2001 for the Lower Mississippi-St. Francis (0802), Upper White (1101), and Lower Arkansas (1111) hydrologic subregions and cataloging units. 


\section{Tables}

1. Management priorities and environmental issues for the Cache and White River National Wildlife Refuges, Lower Mississippi-St Francis (0802) subregion, Arkansas

2A. Station characteristics for gaging stations in the contributing watersheds of the Cache and White River National Wildlife Refuges (NWRs) and vicinity, Arkansas, Missouri, and Oklahoma.

$2 B$. Hydrologic data periods of record for gaging stations in the contributing watersheds of the Cache and White River National Wildlife Refuges and vicinity, Arkansas, Missouri, and Oklahoma.....

3. Annotated list of GIS feature classes, tables, and raster datasets in the geodatabase catalogue for the Cache and White River National Wildlife Refuges and contributing watersheds and vicinity, Arkansas, Missouri, and Oklahoma .....

4A. Database files, tables/worksheets, and table/worksheet descriptions for the hydrologic and landscape database for the Cache and White River National Wildlife Refuges contributing watersheds and vicinity, Arkansas, Missouri, and Oklahoma....... 36

$4 B$. Database field names, field types, and field definitions for the hydrologic and landscape database for the Cache and White River National Wildlife Refuges contributing watersheds and vicinity, Arkansas, Missouri, and Oklahoma.

5. Indicators of Hydrologic Alteration (IHA) hydrologic-parameter groups, environmental-flow-component groups, and parameter and component definitions used in the Cache and White River National Wildlife Refuge IHA analysis

$6 A$. Summary descriptive statistics and percentiles for gage height by water year for gaging stations in the contributing watersheds of the Cache and White River National Wildlife Refuges and vicinity, Arkansas, Missouri, and Oklahoma.

6B. Summary descriptive statistics and percentiles for gage height by calendar year for gaging stations in the contributing watersheds of the Cache and White River National Wildlife Refuges and vicinity, Arkansas, Missouri, and Oklahoma..

7A. Summary descriptive statistics and percentiles for discharge by water year for gaging stations in the contributing watersheds of the Cache and White River National Wildlife Refuges and vicinity, Arkansas, Missouri, and Oklahoma.

7B. Summary descriptive statistics and percentiles for discharge by calendar year for gaging stations in the contributing watersheds of the Cache and White River National Wildlife Refuges and vicinity, Arkansas, Missouri, and Oklahoma.

$8 A$. Selected hydrologic metrics for gage height by water year for gaging stations in the contributing watersheds of the Cache and White River National Wildlife Refuges and vicinity, Arkansas, Missouri, and Oklahoma.

$8 B$. Selected hydrologic metrics for gage height by calendar year for gaging stations in the contributing watersheds of the Cache and White River National Wildlife Refuges and vicinity, Arkansas, Missouri, and Oklahoma.

$9 A$. Selected hydrologic metrics for discharge by water year for gaging stations in the contributing watersheds of the Cache and White River National Wildlife Refuges and vicinity, Arkansas, Missouri, and Oklahoma.

$9 B$. Selected hydrologic metrics for discharge by calendar year for gaging stations in the contributing watersheds of the Cache and White River National Wildlife Refuges and vicinity, Arkansas, Missouri, and Oklahoma.. 
10. Graphical summary files for plots of gage height and discharge data collected at gaging stations in the contributing watersheds of the Cache and White River National Wildlife Refuges and vicinity, Arkansas, Missouri, and Oklahoma

11. Land-cover percentages for the Cache and White River National Wildlife Refuges contributing watersheds and vicinity, Arkansas, Missouri, and Oklahoma, based on the 1992 National Land Cover Database...

12. Land-cover percentages for the Cache and White River National Wildlife Refuges contributing watersheds and vicinity, Arkansas, Missouri, and Oklahoma, based on the 2001 National Land Cover Database .

13. Land-cover-change percentages for the Cache and White River National Wildlife Refuges contributing watersheds and vicinity, Arkansas, Missouri, and Oklahoma, from 1992 to 2001, based on the 1992-2001 National Land Cover Database-Land Cover Change Retrofit product.

\section{Conversion Factors and Datums}

\begin{tabular}{lcl}
\hline \multicolumn{1}{c}{ Multiply } & By & \multicolumn{1}{c}{ To obtain } \\
\hline foot $(\mathrm{ft})$ & Length & \\
mile (mi) & 0.3048 & meter $(\mathrm{m})$ \\
& 1.609 & kilometer $(\mathrm{km})$ \\
\hline acre $(\mathrm{ac})$ & Area & \\
square mile $\left(\mathrm{mi}^{2}\right)$ & 0.4047 & hectare (ha) \\
\hline & 2.590 & square kilometer $\left(\mathrm{km}^{2}\right)$ \\
\hline cubic foot per second $\left(\mathrm{ft}^{3} / \mathrm{s}\right)$ & Flow rate & \\
inch per year (in/yr) & 0.02832 & cubic meter per second $\left(\mathrm{m}^{3} / \mathrm{s}\right)$ \\
\hline
\end{tabular}

Vertical coordinate information is referenced to the National Geodetic Vertical Datum of 1929 (NGVD 29).

Horizontal coordinate information is referenced to North American Datum of 1983 (NAD 83), except where indicated. 


\section{Abbreviations}

$\begin{array}{ll}\text { ADR } & \text { annual data report } \\ \text { ANRC } & \text { Arkansas Natural Resources Commission } \\ \text { ASCI } & \text { American Standard Code for Information Interchange } \\ \text { CGWA } & \text { Critical Ground Water Area } \\ \text { EFC } & \text { Environmental Flow Component } \\ \text { ESRI } & \text { Environmental Systems Research Institute } \\ \text { FIPS } & \text { Federal Information Processing Standards } \\ \text { FAER } & \text { Fisheries: Aquatic and Endangered Resources (Program) } \\ \text { GIS } & \text { geographic information system } \\ \text { HAT } & \text { Hydrologic Assessment Tool } \\ \text { HIP } & \text { Hydroecological Integrity (Assessment) Process } \\ \text { HIT } & \text { Hydrologic Index Tool } \\ \text { HSG } & \text { hydrologic soil group } \\ \text { HUC } & \text { hydrologic unit code } \\ \text { HUC4 } & \text { 4-digit hydrologic-unit code } \\ \text { HUC12 } & \text { 12-digit hydrologic-unit code } \\ \text { IFIM } & \text { Instream Flow Incremental Methodology } \\ \text { IHA } & \text { Indicators of Hydrologic Alteration } \\ \text { LCCR } & \text { Land Cover Change Retrofit (product) } \\ \text { LCV5 } & \text { log base-ten percentiles, coefficient of variation of the set of } \\ \text { PHABSIM } & \text { every 5th percentile (n=19) } \\ \text { MAF } & \text { master address file } \\ \text { MRLC } & \text { Multi-Resolution Land Characteristics Consortium } \\ \text { NATHAT } & \text { National Hydrologic Assessment Tool } \\ \text { NHD } & \text { National Hydrography Dataset } \\ \text { NJHAT } & \text { New Jersey Hydrologic Assessment Tool } \\ \text { NJSCT } & \text { New Jersey Stream Classification Tool } \\ \text { NLCD } & \text { National Land Cover Database } \\ \text { NOAA } & \text { National Oceanographic and Atmospheric Administration } \\ \text { NWIS } & \text { Poter Inforion (Model) } \\ \text { NWhormation System }\end{array}$




$\begin{array}{ll}\text { RBFI } & \text { Richards-Baker Flashiness Index } \\ \text { RDB } & \text { relational database (system) } \\ \text { S\&T } & \text { Status and Trends (Program) } \\ \text { SAS } & \text { Statistical Analysis System } \\ \text { SCT } & \text { Stream Classification Tool } \\ \text { STATSGO } & \text { State Soil Geographic (Database) } \\ \text { TIGER } & \text { Topologically Intergrated Geographic Encoding and Referencing (database) } \\ \text { USACE } & \text { U.S. Army Corps of Engineers } \\ \text { USFWS } & \text { U.S. Fish and Wildlife Service } \\ \text { USGS } & \text { U.S. Geological Survey } \\ \text { WBD } & \text { Watershed Boundary Dataset } \\ \text { WUA } & \text { Weighted Usable Area }\end{array}$




\title{
Hydrologic and Landscape Database for the Cache and White River National Wildlife Refuges and Contributing Watersheds in Arkansas, Missouri, and Oklahoma
}

\author{
By Gary R. Buell, Loren L. Wehmeyer, and Daniel L. Calhoun
}

\section{Abstract}

A hydrologic and landscape database was developed by the U.S. Geological Survey, in cooperation with the U.S. Fish and Wildlife Service, for the Cache River and White River National Wildlife Refuges and their contributing watersheds in Arkansas, Missouri, and Oklahoma. The database is composed of a set of ASCII files, Microsoft Access ${ }^{\circledR}$ files, Microsoft Excel ${ }^{\circledR}$ files, an Environmental Systems Research Institute (ESRI) ArcGIS ${ }$ geodatabase, ESRI ArcGRID ${ }^{\circledR}$ raster datasets, and an ESRI ArcReader ${ }^{\circledR}$ published map. The database was developed as an assessment and evaluation tool to use in examining refugespecific hydrologic patterns and trends as related to water availability for refuge ecosystems, habitats, and target species; and includes hydrologic time-series data, statistics, and hydroecological metrics that can be used to assess refuge hydrologic conditions and the availability of aquatic and riparian habitat. Landscape data that describe the refuge physiographic setting and the locations of hydrologic-data collection stations are also included in the database. Categories of landscape data include land cover, soil hydrologic characteristics, physiographic features, geographic and hydrographic boundaries, hydrographic features, regional runoff estimates, and gaging-station locations. The database geographic extent covers three hydrologic subregions - the Lower Mississippi-St Francis (0802), the Upper White (1101), and the Lower Arkansas (1111) — within which human activities, climatic variation, and hydrologic processes can potentially affect the hydrologic regime of the refuges and adjacent areas. Database construction has been automated to facilitate periodic updates with new data.

The database report (1) serves as a user guide for the database, (2) describes the data-collection, data-reduction, and data-analysis methods used to construct the database, (3) provides a statistical and graphical description of the database, and (4) provides detailed information on the development of analytical techniques designed to assess water availability for ecological needs.

\section{Introduction}

Historically, little emphasis has been placed on the characterization of southeastern National Wildlife Refuge (NWR) hydrologic environments because of a plentiful water supply and lack of perceived stress on refuge aquatic resources. Recently severe droughts and floods, and the increased competition for a limited water supply have changed this picture. The U.S. Fish and Wildlife Service (USFWS) has prioritized southeastern NWRs based on the need for hydrologic characterization (quantity, timing, duration, and diversion of flows) as a management tool for NWR ecological assessment and resource management. Baseline hydrologic characterization and the relation of the present hydrologic regime to reference conditions are requirements for identifying refuge hydrologic stressors and providing the framework for modeling the potential effects of changes in the hydrologic regime on aquatic biota (Buell and others, 2009). Hydrologic data, statistical reductions of these data, and hydrologic metrics that provide information on the magnitude, frequency, duration, timing, and rate of change of hydrologic events can provide useful management tools for meeting refuge objectives. These data are essential for monitoring changes in the hydrologic regime that could place refuge resources at risk. To this end, the Cache and White River NWRs hydrologic and landscape database was developed to provide a framework for hydrologic and landscape characterization and assessment.

Refuge-management objectives for the Cache River NWR (table 1; U.S. Fish and Wildlife Service, 2011a) include protection, preservation, and restoration of wetland habitat and migratory waterfowl; relinkage of fragmented bottomland hardwood and swamp forest habitat; protection of threatened and endangered species; wildlife management for ecosystem integrity; and recreation. Agricultural water use and flow alteration related to upstream channelization are the primary hydrologic stresses for this refuge. 
Table 1. Management priorities and environmental issues for the Cache and White River National Wildlife Refuges, Lower Mississippi-St Francis (0802) subregion, Arkansas.

[NWR, National Wildlife Refuge; U.S. Geological Survey (USGS) hydrologic subregion (and subregion code) shown in figure 1]

\begin{tabular}{|c|c|c|c|c|}
\hline $\begin{array}{l}\text { National } \\
\text { Wildlife } \\
\text { Refuge }\end{array}$ & $\begin{array}{c}\text { Year } \\
\text { established }\end{array}$ & $\begin{array}{l}\text { Refuge area, } \\
\text { in acres }\end{array}$ & Refuge management priorities ${ }^{b}$ & Environmental issues $^{c}$ \\
\hline Cache River & 1986 & $\begin{array}{l}174,800 \\
(67,500)\end{array}$ & $\begin{array}{l}\text { Protection, preservation, and restoration } \\
\text { of wetland habitat } \\
\text { Migratory waterfowl protection } \\
\text { Relinkage of fragmented bottomland } \\
\text { hardwood and swamp forest habitat } \\
\text { through reforestation/afforestation } \\
\text { Protection of endangered species, wild- } \\
\text { life management, and recreation }\end{array}$ & $\begin{array}{l}\text { Agricultural effects on the } \\
\text { hydrologic regime }^{\mathrm{d}} \\
\text { Extensive channelization and } \\
\text { ditching upstream of the refuge } \\
(1920 \text { s and 1930s })\end{array}$ \\
\hline White River & 1935 & $\begin{array}{c}175,200 \\
(160,000)\end{array}$ & $\begin{array}{l}\text { Migratory waterfowl protection } \\
\text { Preservation of one of the largest } \\
\text { remaining bottomland hardwood- } \\
\text { forest ecosystems in the Lower } \\
\text { Mississippi Valley } \\
\text { Forest thinning } \\
\text { Water-level management for protection, } \\
\text { preservation, and restoration of } \\
\text { wetland habitat } \\
\text { Managed wildlife harvesting } \\
\text { Cooperation with other public and } \\
\text { private resource-management } \\
\text { agencies in supporting White River } \\
\text { basin management } \\
\text { Preservation of selected refuge areas and } \\
\text { environments for scientific study }\end{array}$ & $\begin{array}{l}\text { Agricultural effects on the } \\
\text { hydrologic regime } \\
\text { Reservoir operation } \\
\text { Diversion of White River discharge to } \\
\text { agricultural aqueducts upstream of } \\
\text { Cache and White River NWRs for } \\
\text { recharge of the Mississippi River } \\
\text { Valley alluvial aquifer } \\
\text { Dredging and channel maintenance } \\
\text { for navigation } \\
\text { Plans to prevent the Arkansas and } \\
\text { White Rivers from merging } \\
\text { downstream of White River NWR } \\
\text { (levee construction) }^{\mathrm{f}} \\
\text { Backwater from flooding in the lower } \\
\text { section of White River NWR }\end{array}$ \\
\hline
\end{tabular}

${ }^{\text {a }}$ The first number given is acreage within the acquisition boundary. Acreage numbers in parentheses are for land presently acquired (U.S. Fish and Wildlife Service, 2011a,b). Refuge-aquisition boundaries shown in figure 1.

${ }^{b}$ U.S. Fish and Wildlife Service, 2011a,b.

'Steven Earsom, U.S. Fish and Wildlife Service, written commun., August 17, 2007, and William Starkel, U.S. Fish and Wildlife Service, written commun., August 17, 2007; U.S. Fish and Wildlife Service, 2011a,b.

${ }^{\mathrm{d}}$ Arkansas Soil and Water Conservation Commission, 2000; Reed, 2003; Schrader, 2009, 2010; Czarnecki, 2010; Arkansas Natural Resources Commission, 2011.

e U.S. Army Corps of Engineers, 1999, 2011b; U.S. Department of Agriculture, 2011c.

${ }^{\mathrm{f}}$ U.S. Army Corps of Engineers, 2003, 2009, 2011c. 
Refuge-management objectives for the White River NWR (table 1; U.S. Fish and Wildlife Service, 2011b) also include the objectives listed for the Cache River NWR and, additionally, meeting the Mississippi Flyway objectives (Flyways.us, 2011), maintaining the natural diversity of the White River bottomland hardwood ecosystem, cooperating with other public and private resource-management agencies in supporting the holistic management of the White River Basin, and preserving selected refuge areas and environments for scientific study and public enjoyment. Agricultural water use, flow alteration and channel modification related to upstream reservoir operation, and channel modification related to dredging are the primary hydrologic stresses for the White River NWR.

To address NWR water-availability issues, the U.S. Geological Survey (USGS), in cooperation with the USFWS, developed hydrologic and landscape databases for selected southeastern refuges to be used for hydrologic characterization and ecological assessment. Eight NWRs in the USFWS Region 4 area of the southeastern United States were selected for detailed hydrologic characterization as a pilot study and possible prototype for national-scale assessment of water availability for NWRs: (1) Cache River and (2) White River NWRs, Arkansas; (3) Cahaba River NWR, Alabama; (4) Lower Suwannee, (5) Caloosahatchee, and (6) J.N. "Ding" Darling NWRs, Florida; (7) Okefenokee NWR, Florida and Georgia; and (8) Clarks River NWR, Kentucky. This report describes and documents the development, use, and context of these hydrologic and landscape databases, and describes the database for the first two refuges, the Cache River and White River NWRs. This database was developed as an assessment and evaluation tool to use in examining refuge-specific hydrologic patterns and trends as related to water availability for refuge ecosystems, habitats, and target species.

In 2010, the USFWS began a comprehensive national inventory of refuge water resources for all 553 refuges in the NWR System with the goal of providing a database of water quantity and quality, legal water rights, infrastructure, and water-related needs information. The water-resource inventory is expected to take a minimum of 5 years and should provide resource managers a baseline from which to assess the effects of population growth and climate change on the availability of water resources needed to meet refuge management and preservation goals (U.S. Fish and Wildlife Service, 2011c).
Although the USFWS NWR hydrologic and landscape database products are not included in the USFWS waterresource inventory program, the database design, content, and intent for use are consistent with and support the goals of the inventory program, and could provide useful contributions to the program.

The hydrologic and landscape database products for NWRs support the goals of two program areas of the USGS ecosystems science strategy: (1) Fisheries: Aquatic and Endangered Resources (FAER) Program and (2) Status and Trends (S\&T) Program (U.S. Geological Survey 2007a,b). Hydrologic characterization and assessment of NWR aquatic environments provides a baseline for the FAER program goals of understanding the habitat requirements of aquatic biota and developing a framework for the management, conservation, and restoration of aquatic resources. The NWR hydrologic baseline is also a critical component of the S\&T goal of long-term ecosystem monitoring, in this case, the status of the forestedwetland ecosystems in the Cache and White River NWRs.

\section{Purpose and Scope}

This report describes and documents the development, use, and context of a hydrologic and landscape database for the Cache River and White River NWRs and contributing watersheds in Arkansas, Missouri, and Oklahoma (fig. 1). The database was developed as an assessment and evaluation tool for the refuge managers and USFWS scientific and technical staff to use in examining refuge-specific hydrologic patterns and trends as related to water availability for refuge ecosystems, habitats, and target species. The report (1) serves as a user guide for the database, (2) describes the datacollection, data-reduction, and data-analysis methods used to construct the database, (3) provides a statistical and graphical description of the database, and (4) provides detailed information on the development of analytical techniques designed to assess water availability for ecological needs.

The database includes hydrologic time-series data, statistics, and hydroecological metrics that can be used to assess refuge hydrologic conditions and the availability of aquatic and riparian habitat. Landscape spatial data that describe the refuge environmental setting and the locations of hydrologicdata collection stations are also included in the database. 


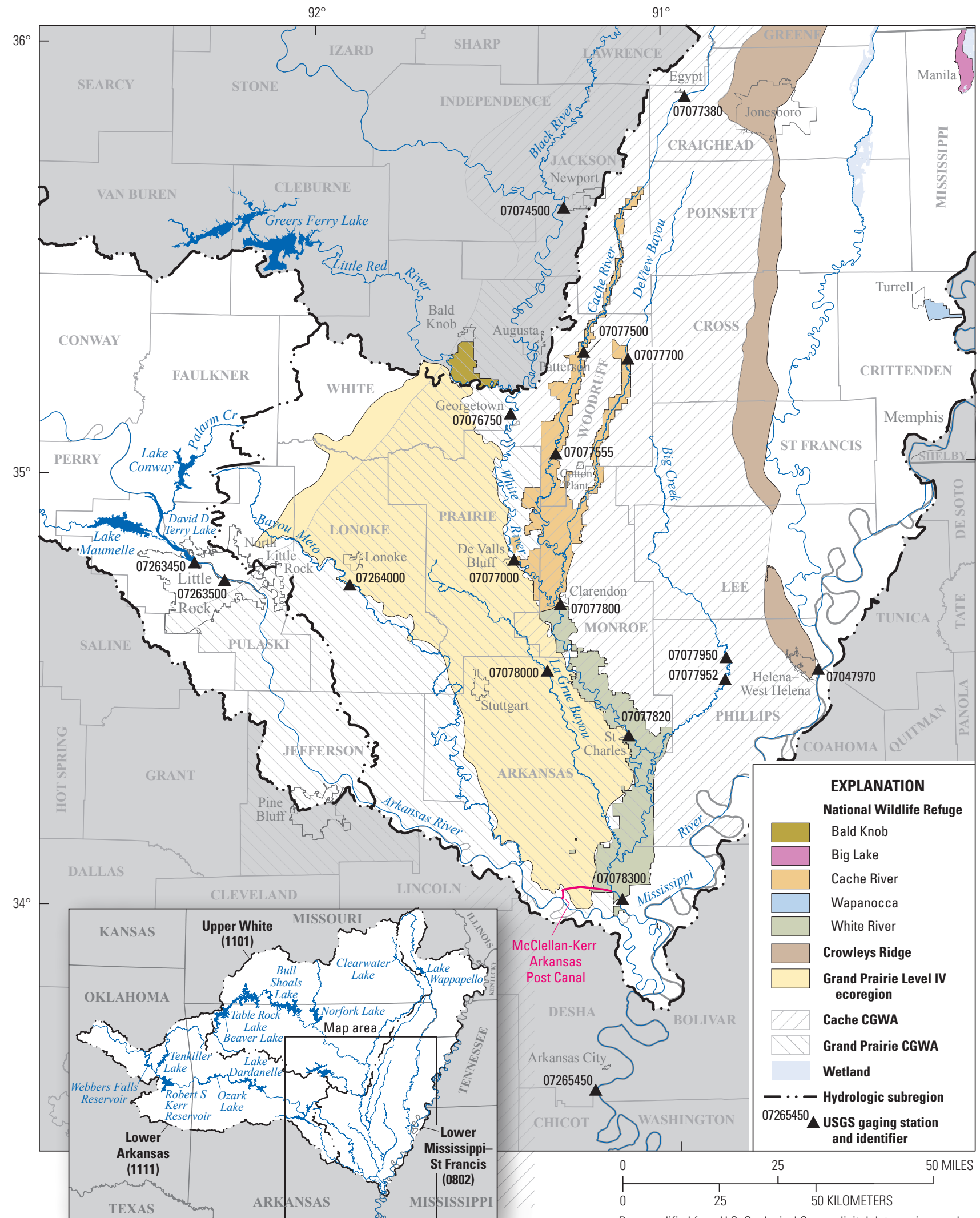

Base modified from U.S. Geological Survey digital data, various scales. See table 3 for details

Figure 1. Location of the Cache and White River National Wildlife Refuges (NWRs) and vicinity with major contributing watersheds, waterways, gaging stations, the Cache and Grand Prairie Critical Groundwater Areas (CGWAs), Crowleys Ridge (Bluff Hills Level IV ecoregion), and Grand Prairie Level IV ecoregion. Map inset, lower left, shows the hydrologic subregions (4-digit hydrologic units) that define the contributing watershed area for the Cache and White River NWRs: 0802, Lower Mississippi-St Francis; 1101, Upper White; and 1111, Lower Arkansas; and locations of major rivers and reservoirs. Individual wetland areas less than 20 square kilometers not shown. 


\section{Physiographic Setting}

The contributing watersheds of the Cache and White River NWRs, as defined in this report, include three hydrologic subregions with the following 4-digit hydrologic-unit codes (and extents) (HUC4s; Seaber and others, 1994; U.S. Department of Agriculture, 2011a):0802, Lower MississippiSt Francis, drainage area, 16,840 square miles $\left(\mathrm{mi}^{2}\right) ; 1101$, Upper White, drainage area, 22,350 $\mathrm{mi}^{2}$; and 1111 , Lower Arkansas, drainage area, $15,830 \mathrm{mi}^{2}$ (fig. 1). These subregions include the refuge-acquisition areas and hydrologic features that have direct and measurable influence on refuge hydrology as well as features that have little or no hydrologic connection. The contributing area, operationally defined for this and subsequent databases, is the smallest set of contiguous HUCs, at the relevant HUC scale - in this case, HUC4s (hydrologic subregions) - that include the refuge-acquisition area(s) and relevant hydrologic and landscape features. Contributing HUCs are not split below the relevant scale, so there may be sections of one or more contributing HUCs that are not hydrologically connected to the refuges. The Lower Arkansas hydrologic subregion, for example, has little direct hydrologic connection to the refuges; however, it was included in this report because hydrologic conditions in this subregion can affect hydrologic conditions within lower White River NWR (for example, through backwater flooding). Although the refuge-proximal areas within each subregion likely are more hydrologically connected than peripheral subregion areas, activities throughout these subregions, particularly reservoir operations, discharges, withdrawals, diversions, and dredging, all have the potential to either directly or indirectly affect the refuges.

The refuges are located within the lower part of the Lower Mississippi-St Francis subregion, most of which is in the Mississippi Alluvial Plain Level III ecoregion (figs. 1 and 2; U.S. Environmental Protection Agency, 2011). The Mississippi Valley Loess Plain occupies much of the divide, known as Crowleys Ridge, between the lower part of the St. Francis River and the Cache River (fig. 1). Small upland sections of the Lower Mississippi-St Francis subregion are located in the Ozark Highlands to the north and in the Arkansas Valley and Ouachita Mountains to the south. Most of the Upper White subregion is in the Ozark Highlands with small sections along the southern and eastern divides located in the Boston Mountains, the Arkansas Valley, and the Mississippi Alluvial Plain. The Lower Arkansas subregion is split between the Arkansas Valley in the center, the Boston Mountains to the north, and the Ouachita Mountains to the south (fig. 2). Mean-annual precipitation for the contributingwatershed area ranges from 39 to 47 inches per year (in/yr) in the Missouri and Oklahoma parts of the contributing watersheds to 47 to $53 \mathrm{in} / \mathrm{yr}$ in the Arkansas part, based on 1961-90 climate normals (Gibson and others, 2002; Daly, 2002). Mean-annual runoff for the period 1951-80 (Gebert and others, 1987) ranges from a low of 5 to $10 \mathrm{in} / \mathrm{yr}$ in the western part of the Lower Arkansas subregion to a high of 18 to $22 \mathrm{in} / \mathrm{yr}$ in the eastern part of this subregion, with intermediate ranges for the Lower Mississippi-St Francis and Upper White subregions. Mean-annual runoff ranges between 12 to $20 \mathrm{in} / \mathrm{yr}$ in the Upper White subregion and between 16 to $20 \mathrm{in} / \mathrm{yr}$ in the Lower Mississippi-St Francis subregion.

Figures $3 A-D$ show the distribution of the hydrologic soil groups (HSGs) A through D for the 38 hydrologic cataloging units in the contributing-watershed area as areal percentages of each HUC. The HSGs used in this analysis are State Soil Geographic (STATSGO) Database attributes (U.S. Department of Agriculture, 1994; Soil Survey Staff, 2011) that have been aggregated to the soil map unit and provided in raster format at 100-meter $(\mathrm{m})$ resolution. The 100-m dataset is a finer-resolution version of the 1-kilometer STATSGO grid developed by Wolock (1997). The HSG data are only included in the 100-m dataset. Hydrologic soil groups typically are used together with land use, land-management practices, and hydrologic conditions to calculate runoff-curve numbers that can be used to model rainfall-runoff relations (U.S. Department of Agriculture, 2009, 2011b). Hydrologic soil groups A through $\mathrm{D}$ follow a progression from low to high runoff potential or, conversely, high to low infiltration capacity. 


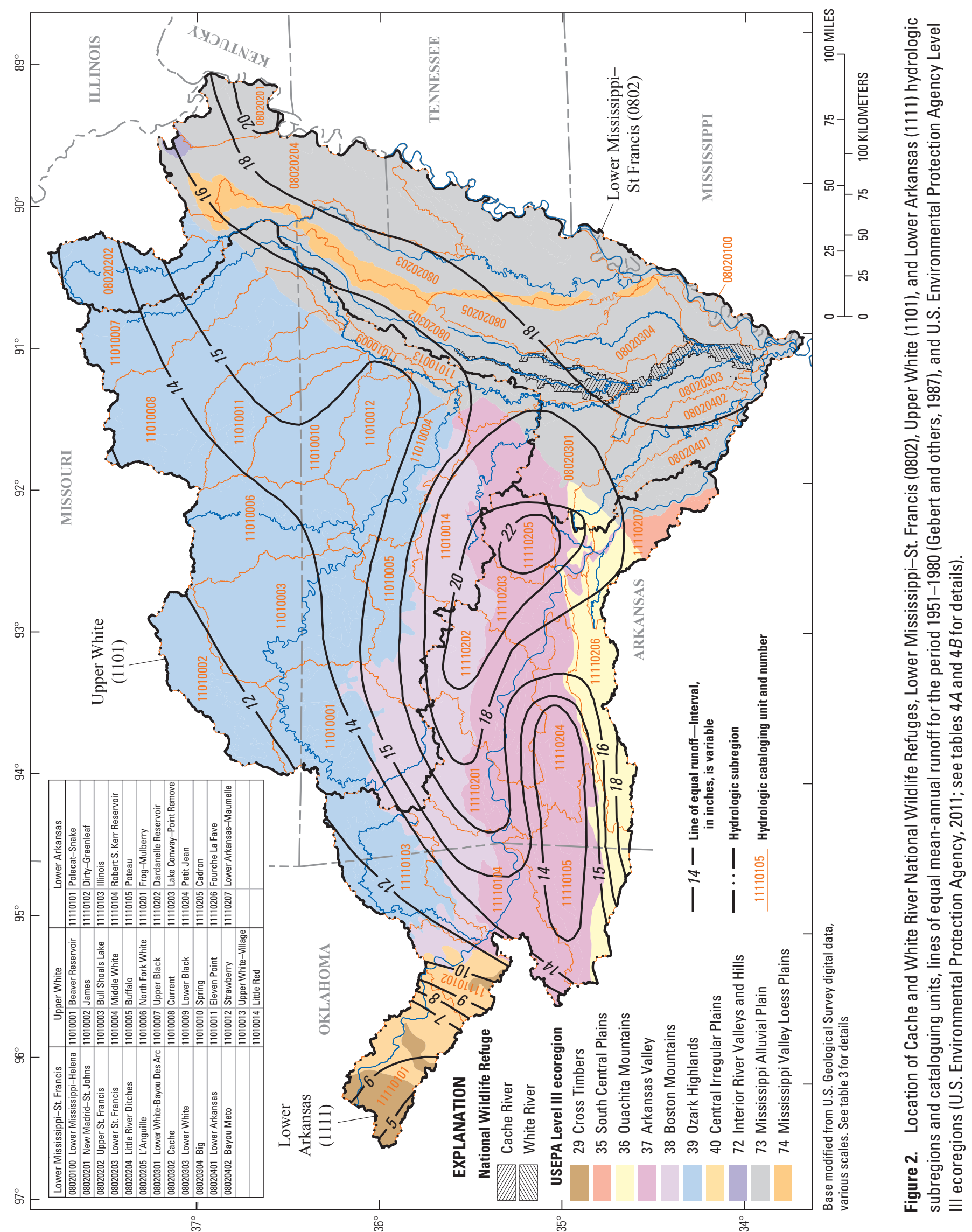




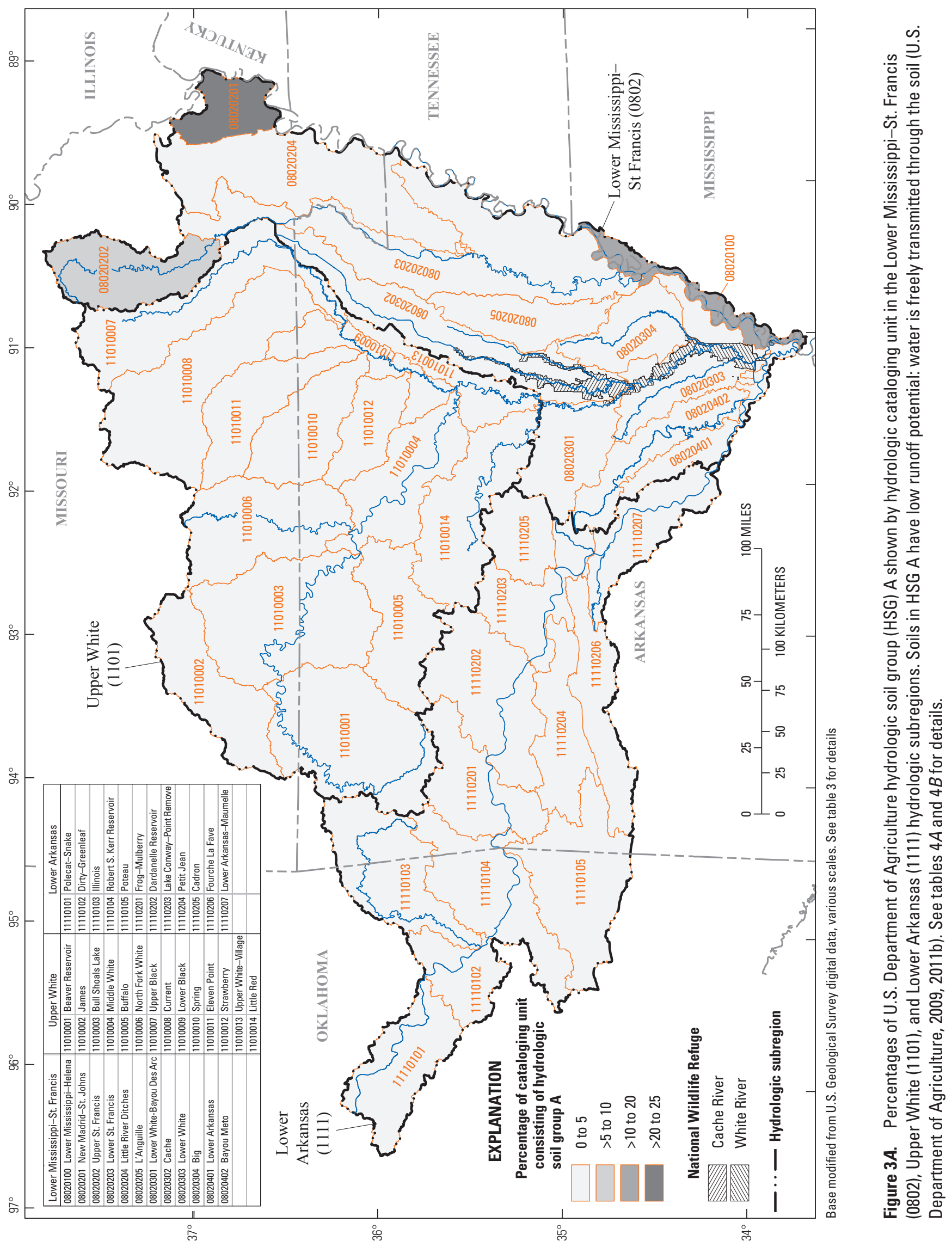




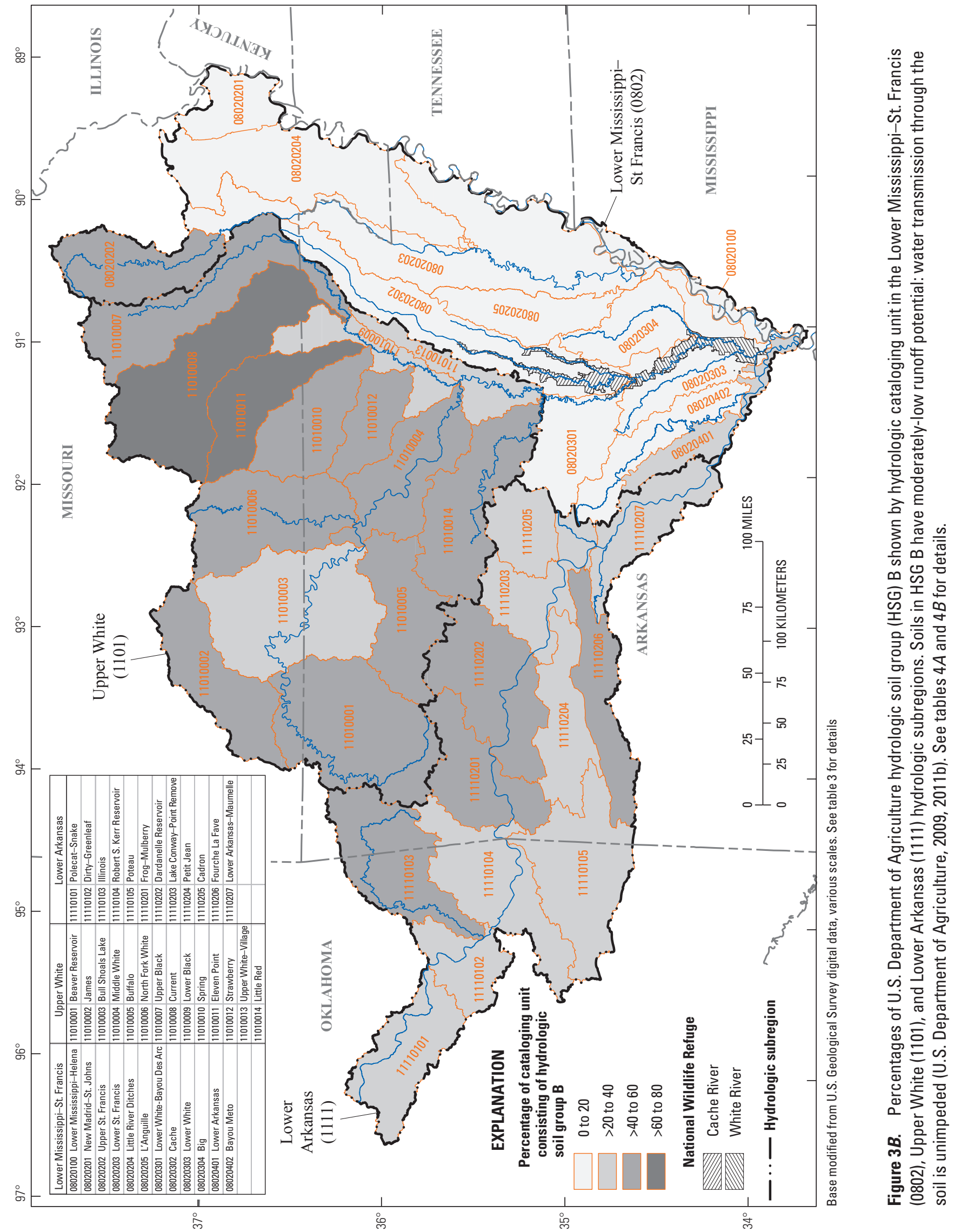




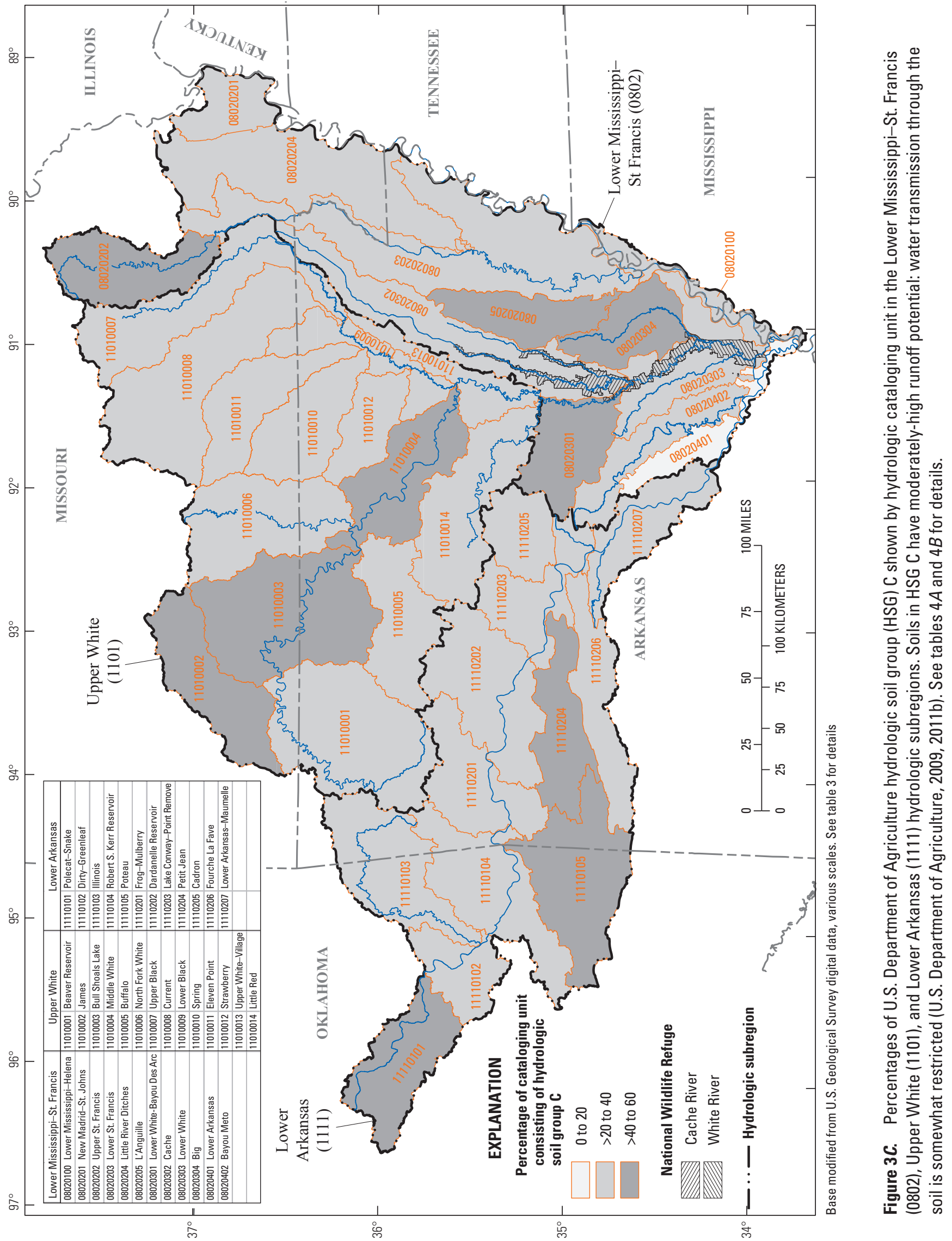




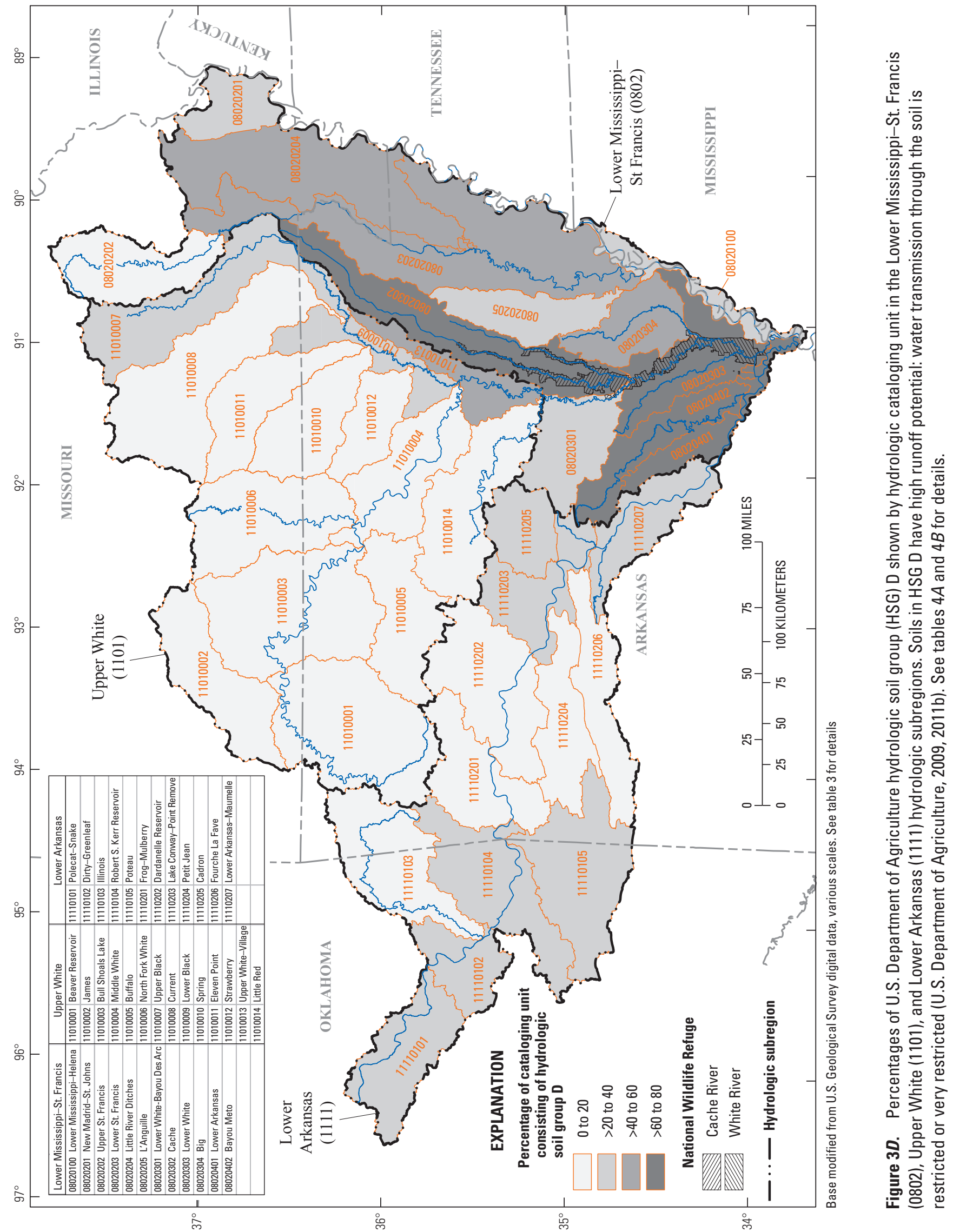




\section{Refuge Setting}

The NWR System was established in 1903 when then President Theodore Roosevelt designated Pelican Island in Florida as the Nation's first wildlife refuge. The NWR System presently has 553 NWRs, 38 wetland-management districts, and other designated units, covering more than 150 million acres. The primary goal of the NWR System is the conservation, management, and restoration of fish, wildlife, and plant resources and habitats; additional goals include support for wildlife-management-related research and recreational uses that include hunting, fishing, wildlife observation, photography, environmental education, and interpretation (U.S. Fish and Wildlife Service, 2011d). This section of the report discusses the establishment of the Cache and White River NWRs, summarizes the refuge-management objectives, and discusses activities and hydrologic processes within the contributing watersheds that potentially could affect the NWR hydrologic environments.

\section{Cache River National Wildlife Refuge}

The Cache River NWR was established in 1986 primarily to provide habitat for migratory birds, as well as native fish and other wildlife species, and to conserve and restore native bottomland hardwood forest in the lower Mississippi Valley (U.S. Fish and Wildlife Service, 2011a). Other management objectives include relinkage of fragmented bottomland hardwood and swamp forest habitat; protection of threatened and endangered species; wildlife management for ecosystem integrity; and recreation (U.S. Fish and Wildlife Service, 2011a). The refuge presently includes 67,500 acres in the floodplains of the Cache and White Rivers and Bayou DeView in parts of Jackson, Monroe, Prairie, and Woodruff Counties in east-central Arkansas (approximately the lower half of the Cache River, fig. 1). The Cache River NWR is managed as part of the Central Arkansas Refuges Complex, which also includes Bald Knob NWR, Bald Knob, Ark.; Big Lake NWR, Manila, Ark.; and Wapanocca NWR, Turrell, Ark. The approved refugeacquisition boundary area is approximately 175,000 acres. Much of the refuge habitat is forested wetland that is protected as a Ramsar "Wetland of International Importance" (Ramsar, 2011). The Cache River refuge wetlands are a primary wintering area for mallard ducks in the continental United States.

\section{White River National Wildlife Refuge}

The White River NWR was established in 1935, primarily for the protection of migratory birds, but also for the protection of one of the largest remaining bottomland hardwood forests in the lower Mississippi Valley (U.S. Fish and Wildlife Service, 2011b). The refuge presently includes 160,000 acres of floodplain located along a 90-mi reach of the lower White River and along a 3-mi section of the McClellan-Kerr Arkansas Post Canal (U.S. Army Corps of Engineers, 2011a) in parts of Arkansas, Desha, Monroe, and
Phillips Counties in east-central Arkansas (fig. 1). The refuge habitat resources are managed in a manner consistent with the objectives of the Mississippi Flyway Council to provide optimal migratory-bird habitat (Flyways.us, 2011). Combined, the Cache and White River NWRs have the largest concentration of wintering mallard ducks in the Mississippi Flyway (U.S. Fish and Wildlife Service, 2011b).

\section{Environmental Issues}

Potential hydrologic stresses on the Cache and White River NWRs include the effects of hydropower regulation; channelization and ditching; agricultural, municipal, and industrial water use, both surface-water and groundwater withdrawal (Arkansas Soil and Water Conservation Commission, 2000; Arkansas Natural Resources Commission, 2007, 2009, 2011; U.S. Army Corps of Engineers, 1999, 2011b); dredging for navigation-channel maintenance (table 1; URS, 2004; U.S. Army Corps of Engineers, 2003, 2009, 2011a,c); changes in land cover and land use; water-quality effects of various land uses; and climate variability. Water-quality issues typically relate to land application of fertilizers and pesticides, erosion and deposition of sediment, and municipal and industrial wastewater discharge. Although some of these topics are addressed in this section, a thorough presentation and discussion is beyond the scope of this report.

Three major reservoirs are located on the upper White River (Beaver Lake, dam closure, 1966; Table Rock, 1959; and Bull Shoals, 1951) and three are located on major tributaries of the upper White River - one each on the North Fork River (Norfolk Lake, 1944), the Black River (Clearwater Lake, 1948), and the Little Red River (Greers Ferry Lake, 1964) (shown on location inset, fig. 1). These reservoirs were constructed by the U.S. Army Corps of Engineers, primarily for flood control and hydropower generation, but also for public water supply, recreation, and the ecological needs of fish and wildlife, under the authorization of various flood-control acts (U.S. Army Corps of Engineers, 2011d) and partly in response to the catastrophic floods of 1915, 1927, and 1937 (Arkansas Studies Institute, 2011). The combined storage capacity of these reservoirs reserved for flood control is approximately 29 percent of the mean-annual discharge for one year at the White River Clarendon streamgage (USGS 07077800, fig. 1), based on 53 water years from 1929 to 1993; and approximately 33 percent at the White River DeValls Bluff streamgage (USGS 07077000, fig. 1), based on 41 water years from 1950 to 2009 . The combined storage capacity reserved for hydropower generation is 25 and 27 percent respectively, based on the same criteria. Thus, there is a large potential range in alteration of downstream flow regimes, depending on reservoir operations and release patterns. The Cache River contains no reservoirs, but much of the upper half of the Cache River was extensively channelized during the 1920s and 1930s. However, the reach within the Cache River NWR land-acquisition area has not been channelized (Arkansas Studies Institute, 2011). 
Most of the water use in the lower White River Basin is agricultural, primarily in the form of irrigation withdrawals from either the Grand Prairie or Cache sections of the Mississippi River Valley alluvial aquifer (hereafter referred to as the alluvial aquifer) for rice, soybeans, cotton, and, recently, aquaculture (Arkansas Soil and Water Conservation Commission, 2000; Reed, 2003; Czarnecki, 2010; Schrader, 2010). The Grand Prairie section of the alluvial aquifer is situated between the lower Arkansas and the lower White Rivers (fig. 1). This section of the alluvial aquifer is largely coincident with the Grand Prairie Level IV ecoregion. The Grand Prairie Area Demonstration Project, currently under construction, will divert water from the lower White River at DeValls Bluff, Arkansas to alleviate aquifer depletion (U.S.

Army Corps of Engineers, 1999, 2011b; U.S. Department of Agriculture, 2011c). The Cache section of the alluvial aquifer is situated between Crowleys Ridge to the east and the Cache River and DeView Bayou to the west. There is also substantial pumpage from the Sparta-Memphis aquifer in the Mississippi Embayment aquifer system for agricultural, municipal, and industrial water use (Schrader, 2009).

The increased demand for water from all sectors (municipal, industrial, and agricultural) is underscored by population trends in the decadal census data for the 107 counties that are wholly or partly within the contributing watershed area for the Cache and White River NWRs (fig. 1). The population of this 107-county area increased from 2.89 million in 1930 to 3.19 million in 1970, an 11-percent increase, and then to 5.12 million in 2010, a 61-percent increase from 1970 (U.S. Census Bureau, 2011a).

In 1998, Arkansas, Jefferson, Prairie, most of Lonoke, and the southeastern sections of Pulaski and White Counties, Ark., were designated as the Grand Prairie Critical Ground Water Area (CGWA, fig. 1) by the Arkansas Natural Resources Commission (ANRC) because of substantial and continuing declines in groundwater levels in the alluvial and Sparta-Memphis aquifers (Arkansas Natural Resources Commission, 2011). In 2009, the parts of Clay, Craighead, Cross, Greene, Lee, Poinsett, and St. Francis Counties, Ark., on the western side of Crowleys Ridge were designated as the Cache CWGA by the ANRC because groundwater levels had dropped below half the saturated thickness of the alluvial aquifer (Arkansas Natural Resources Commission, 2011; Czarnecki, 2010; Schrader, 2010). Regional-scale hydrologic connections between the major rivers and tributaries and the alluvial aquifer in the Lower Arkansas River and Lower White River Basins allow water transfer between the streams and the alluvial aquifer (Reed, 2003). Prior to substantial groundwater withdrawal, the alluvial aquifer typically sustained dry-season base-flows. Hydraulic gradients have been reversed, however, by extensive agricultural groundwater withdrawals in much of the lower White River Basin. This is particularly the case in the ANRC CGWAs and the rivers now typically recharge the alluvial aquifer (Reed, 2003).

A 244-mi long navigable channel is maintained in the lower White River from Newport, Ark., (river mile 254) to the
McClellan-Kerr Arkansas Post Canal (subsequently referred to as the Arkansas Post Canal, river mile 10) at a dredged depth of 4.5 feet (ft) from Newport to Augusta and $8 \mathrm{ft}$ from Augusta to the canal. The current authorization is for a channel $4.5 \mathrm{ft}$ deep and $100 \mathrm{ft}$ wide for the Newport-to-Augusta reach at river stages equivalent to or exceeding $12 \mathrm{ft}$ at the Clarendon streamgage (USGS 07077800), and $8 \mathrm{ft}$ deep and $125 \mathrm{ft}$ wide for the Augusta-to-Arkansas Post Canal reach (U.S. Army Corps of Engineers, 2003, 2009, 2011c; fig. 1). Engineering studies recommended that the Newport-to-Arkansas Post Canal reach be dredged to a depth of 9 feet and a width of $125 \mathrm{ft}$. This recommendation is the focus of a project review plan of the White River Navigation Improvement Project, originally authorized in 1986, de-authorized in 1988, and re-authorized in 1996 under the Water Resources Development Act (U.S. Army Corps of Engineers, 2009, 2011c).

\section{Methods Used for Database Construction}

The hydrologic and landscape database for the Cache and White River NWRs and contributing watersheds was constructed from multiple Federal and State data sources. The hydrologic data — gage height and discharge — primarily are from the USGS National Water Information System (NWIS) database (U.S. Geological Survey, 2011a), but also from U.S. Army Corps of Engineers (USACE) digital files (U.S. Army Corps of Engineers, 2011e). Sources of the tabular and spatial geographic information system (GIS) landscape data are listed in table 3. Categories of landscape data include land cover, soil hydrologic characteristics, physiography, geographic and hydrographic boundaries, hydrographic features, regional runoff, and gaging-station locations. The database also includes statistics and metrics of the hydrologic data, copies of the USGS annual-data-report (ADR) manuscripts for the active gaging stations, and plots of the hydrologic data and selected derivative statistics and metrics. All data retrievals were Web based.

Hydrologic-data processing, statistical reduction of hydrologic data, most table generation, and plot generation were done with custom Statistical Analysis System (SAS) computer programs (SAS Institute Inc., 2011). Spatial GISdata processing, statistical reduction and spatial analysis of GIS data, and most figure generation were done with ESRI ArcGIS ${ }^{\circledR}$ software (ESRI, 2008, 2011a,c). Database tabular data are provided in ASCII, Microsoft Access ${ }^{\circledR}$, and Microsoft Excel ${ }^{\circledR}$ formats. Database spatial data are provided in ESRI ArcGIS ${ }^{\circledR}$ file-geodatabase (ESRI, 2008) and ArcGRID® raster (ESRI, 2011a) formats. Data accessibility requires Microsoft Office ${ }^{\circledR}$ software for full use of the Microsoft Access ${ }^{\circledR}$ and Excel ${ }^{\circledR}$ files, and ESRI ArcGIS ${ }^{\circledR}$ software for full use of the ESRI filegeodatabase and raster files. Read access to the Microsoft Excel ${ }^{\circledR}$ files is provided by the free Microsoft Excel Viewer software (Microsoft, 2011). Read access to the ESRI file-geodatabase and raster files in published-map format (ESRI, 2008) is provided by the free ESRI ArcReader ${ }^{\circledR}$ software (ESRI, 2011b). The database is available online at $h t t p: / / p u b s . u s g s . g o v / o f / 2012 / 1026 /$. 


\section{Database Geographic Extent}

The database geographic extent is based on the concept of contributing watersheds, defined by the 12-digit USGS hydrologic units (HUC12s) as the spatial framework (Seaber and others, 1994; U.S. Department of Agriculture, 2011a). The scale-appropriate contributing-watershed area for this database is the contiguous set of hydrologic subregions (4-digit hydrologic units, HUC4s) in which the Cache and White River NWRs and hydrologically-relevant features and sreamgaging stations are located. This areal extent includes three subregions, the Upper White (1101), the Lower MississippiSt. Francis (0802), and the Lower Arkansas (1111) (fig. 1). Although subareas of the Lower Mississippi-St. Francis and Lower Arkansas subregions are not hydrologically connected to the Cache and White River NWRs, contributing HUCs are not subdivided when defining the geographic extent.

\section{Hydrologic Data Sources and Data-Retrieval Procedures}

Gaging stations were selected within the geographic extent and limited to those stations that were close enough to the refuges, either upstream, downstream, within the refuge boundary, or along nearby streams and rivers that are hydrologically connected, to provide hydrologically relevant data. Hydrologic data, namely, gage height and discharge, collected at 18 gaging stations met these criteria and are included in the database (fig. 1, tables $2 A-B$; tables $2-13$ are shown at the back of the report).

Continuous-record water-level data are being collected at a number of wells in the Mississippi River Valley alluvial aquifer in the vicinity of the Cache and White River NWRs; however, these data are not included in this report, nor in the database. The inclusion of continuous-record water-level data and summary descriptive statistics and hydrologic metrics derived from these data will be considered as a possible addition if database revisions are released.

No continuous-record water-quality data have been collected at the gage locations listed in table $2 A$ (for example, daily values for water temperature, dissolved oxygen, specific conductance, $\mathrm{pH}$, and turbidity frequently are collected at many USGS gaging stations). Although considerable periodic water-quality data have been collected as part of routine monitoring operations and topical investigations, these data are not included in this report, nor in the database. Continuous-record water-quality data are within the scope of the report and database and would have been included if these data had been collected. The inclusion of periodic water-quality data or an inventory and summary of these data will be considered as a possible addition if database revisions are released.

Mean-daily values for gage height ( $\mathrm{ft}$ above or below NGVD 29) and discharge (cubic feet per second, $\mathrm{ft}^{3} / \mathrm{s}$ ) were retrieved from digital files of the USGS NWIS database
(U.S. Geological Survey, 2011a) through the public Web interface (NWISWeb: http://waterdata.usgs.gov/usa/nwis/nwis; U.S. Geological Survey, 2002, 2011b,c). Additional data for four gaging stations were obtained either by written request and (or) from digital files of the USACE (U.S. Army Corps of Engineers, 2011e). Data were retrieved in tab-delimited ASCII files formatted as relational database (RDB) tables, an ASCII relational-database structure used by the USGS as a standard data-export format from the NWIS and NWISWeb databases (Hobbs, 2011).

Station characteristics are presented in table $2 A$ and station periods of record for gage height and discharge are presented in table $2 B$. Twelve of the 18 stations have daily record for gage height, 16 stations have daily record for discharge, and 10 stations have daily record for both gage height and discharge; gaging-station locations are shown in figure 1 . In table $2 B$, the period of record, number of complete years, number of partial years, and record-completeness fraction are given for both water-year and calendar-year periods. The fraction-of-total-record-length calculation is based on complete beginning and ending water or calendar years as well as complete intervening years. Therefore, the fraction-of-total-record-length numbers may be different for water years when compared to calendar years. The period of record may, in some cases, be longer than the number of complete plus incomplete years, indicating that there are intervening years with no record.

The USGS has published the basic-data records for gaging stations in a series of annual or multiple-year water-data reports since 1888, when a systematic study of the surface waters of the United States was started by the then hydrographic branch (presently the Water Mission Area) of the USGS (Hoyt and Wood, 1905). These data were published through the 1961 water year, primarily in water-supply and irrigation papers ("water-supply papers" in later years), but also in annual reports to the Director of the USGS, bulletins, and circulars. Commencing with the 1962 water year, the water-data report series was established as the publication format for basicdata dissemination (U.S. Geological Survey, 2011d). These reports were State-based through the 2005 water year and beginning with the 2006 water year, a national-report series was established (Annual Data Reports [ADRs]) that is digital and available online (http://wdr.water.usgs.gov/). Most of the continuous-record (daily values) and periodic data collected at USGS gaging stations are published in these reports and are available online through NWISWeb (U.S. Geological Survey, 2011b). Each ADR manuscript contains a description of the gaging-station installation and location, a station history, and periods of record for all data collected at the station. The station history includes information on the conditions that define the flow regime at that location, and, therefore, is a useful reference in hydrologic analysis. The ADR manuscripts for active gaging stations listed in table $2 A$ are included in appendix 1 as Adobe Portable Document Format (PDF) files (adr_pdf directory). 


\section{Landscape Data Sources}

Landscape spatial data that describe the refuge environmental setting and the locations of hydrologic-data collection stations are also included in the database. Categories of landscape data include GIS layers for land cover and land use, county-level population data, soil hydrologic characteristics, physiography, geographic and hydrographic boundaries, hydrographic features, regional runoff estimates, and gaging station locations (tables 3, $4 A-B$ ).

Land-cover data were retrieved from the National Land Cover Database (NLCD) and include the 1992 and 2001 NLCDs (U.S. Geological Survey, 2008a; Multi-Resolution Land Characteristics Consortium [MRLC], 2011a) and the NLCD 1992-2001 Land Cover Change Retrofit product (1992-2001 NLCD-LCCR; Multi-Resolution Land Characteristics Consortium [MRLC], 2011b; Fry and others, 2008).

Soil characteristics included in the database are STATSGO-derived taxonomic soil order, hydric classification, and hydrologic soil groups (U.S. Department of Agriculture, 1994, 2009, 2011b; Soil Survey Staff, 2011; Wolock, 1997). The STATSGO database is an archived digital version of the U.S. General Soil Map published in 1994 by the U.S. Department of Agriculture. STATSGO spatial and tabular data were revised and updated in 2006 and published online as STATSGO2 (U.S. Department of Agriculture, 2011d).

U.S. Environmental Protection Agency Level III and Level IV ecoregions provide the physiographic framework for the database (U.S. Environmental Protection Agency, 2011). Level III and Level IV ecoregions are hierarchical subdivisions of the Level I and Level II ecoregions of the United States derived from Omernik (1987) and subsequent revisions of Omernik's ecoregions to provide a spatial framework for ecosystem research and monitoring.

Refuge boundaries are the land-acquisition boundaries approved by the U.S. Fish and Wildlife Service when each refuge was established (U.S. Fish and Wildlife Service, 2011e). County boundaries are a feature set in the highresolution 2010 Topologically Integrated Geographic Encoding and Referencing (TIGER)/Line Shapefiles in the U.S. Census Bureau's master address file (MAF)/TIGER database (U.S. Census Bureau, 2011). State boundaries are dissolved from the county boundaries, and both datasets are clipped to the National Oceanic and Atmospheric Administration (NOAA) medium-resolution shoreline (National Oceanic and Atmospheric Administration, 2011). The digital-vector shoreline was digitized from NOAA National Ocean Survey navigation charts for the conterminous United States coastline. These charts range in scale from 1:10,000 to $1: 600,000$, and the finished product/dataset was produced at a scale of 1:80,000. This dataset was used to clip the county/state boundaries because the original datasets have the administrative boundaries which, for coastal counties/ states, include open ocean and obscure the actual coastline.
The basin-boundary datasets include the HUC12 boundaries in the Watershed Boundary Dataset (WBD; U.S. Department of Agriculture, 2011a) and the 4-, 8-, and 10-digit derivatives of the HUC12s-USGS subregions, cataloging units, and 10-digit HUCs (Seaber and others, 1994).

Hydrography layers include the flowline and waterbody features of the the high-resolution National Hydrography Dataset (NHD; U.S. Geological Survey, 2011e). The highresolution NHD features are those streams and water bodies digitized from the delineated features on the USGS 1:24,000scale topographic quadrangles. The NHD is a digital vector dataset with an embedded flow network designed to be used in mapping applications and analysis of surface-water systems.

Regional runoff numbers are derived from a digitized version of the average annual runoff map for the United States for 1951-80 (Gebert and others, 1987). Runoff was determined from streamflow data collected at 5,951 USGS gaging stations during 1951-80. Gaging stations were selected to represent the geographical distribution of runoff from tributary streams rather than major rivers in order to more accurately represent runoff conditions at local-to-regional scales (Gebert and others, 1987).

Gaging-station locations and station-description data for the 18 USGS gaging stations included in this report/ database were retrieved from the USGS NWISWeb database (U.S. Geological Survey, 2002, 2011b,c). Detailed station descriptions are also included in the USGS ADR manuscripts available online (U.S. Geological Survey, 2011d; appendix 1).

\section{Database Design and Directory Structure}

The hydrologic and landscape database includes all tabular data in a set of Microsoft Access ${ }^{\circledR} 2007$ files and(or) Microsoft Excel ${ }^{\circledR} 2007$ files (tables $4 A-B$, and 5). All data contained in the Microsoft Access ${ }^{\circledR}$ files are also contained in the Microsoft Excel® files. Spatial vector data are included as an ESRI ArcGIS ${ }^{\circledR}$ file geodatabase (ESRI, 2008), and spatial raster data are included as ESRI ArcGRID ${ }^{\circledR}$ raster datasets (ESRI, 2011a; table 3). All spatial vector and raster data are also packaged in an ESRI ArcReader ${ }^{\circledR}$ published map project (ESRI, 2011b). The raw tabular hydrologic data are also provided as ASCII RDB tables (Hobbs, 2011) in the original file format as retrieved from the USGS NWISWeb database (U.S. Geological Survey, 2011b). Users without access to Microsoft Office ${ }^{\circledR} 2007+$ can download and install the Microsoft Excel Viewer ${ }^{\circledR}$ that allows the user to read, view, print, and export Microsoft Excel ${ }^{\circledR}$ 97+ workbooks (Microsoft, 2011). Microsoft does not provide a reader for Microsoft Access ${ }^{\circledR}$. However, the free office-productivity suite OpenOffice.org ${ }^{\mathrm{TM}}$ provides read and write access to Microsoft Access ${ }^{\circledR}$ and Microsoft Excel ${ }^{\circledR}$ files (OpenOffice. $\left.\operatorname{org}^{\mathrm{TM}}, 2011\right)$. Users without access to ESRI ArcGIS ${ }^{\circledR}$ Desktop $10+$ can download and install the free ESRI ArcReader ${ }^{\circledR} 10$ software that allows read, view, print, and identify access to 
ArcGIS $®$ feature and raster datasets that have been packaged in an ESRI ArcReader ${ }^{\circledR}$ published map project (ESRI, 2011b). The identity function allows the user to interrogate the attribute table of a feature or raster dataset, one record at a time. However, to use the spatial data in GIS applications requires either ESRI ArcGIS ${ }^{\circledR}$ software or an equivalent software product that can import ESRI ArcGIS ${ }^{\circledR}$ files.

The tabular hydrologic data include the raw daily-values data for gage height and discharge, statistical-summary data, selected hydrologic metrics, and the Indicators of Hydrologic Alteration (IHA) parameters and Environmental Flow Components (EFCs; The Nature Conservancy, 2007, 2009). The tabular GIS landscape data include zonal summaries of land cover, soil-hydrologic characteristics, and physiography. The raw hydrologic data are aggregated by calendar year (Jan. 1 through Dec. 31) and water year (Oct. 1 through Sept. 30) for annual summaries, and also by calendar decade, by calendar year and month, by calendar month over the period of record, and by Julian day over the period of record for both calendar and water years. The long-term (period of record) monthly and daily summary data are for complete years only. The longterm monthly summary data are based on both mean-daily values and monthly mean values. There are three Microsoft Access ${ }^{\circledR}$ files, the first of which is for raw hydrologic data (cwt_tabular_hydrostats_raw.accdb), the second for the hydrologic statistical-summary data (cwt_tabular_hydrostats. $\mathrm{accdb}$ ), and the third for the hydrologic metrics (cwt tabular hydmetrics.accdb). All Microsoft Access ${ }^{\circledR}$ tables, the IHA output, and the tabular GIS landscape data are available as Microsoft Excel ${ }^{\circledR}$ worksheets. The hydrologic raw-data and hydrologic statistical-summary-data worksheets are bundled into separate workbooks, one for each parameter (gage height, cwt_tabular_hydrostats_gmn.xlsx; discharge, cwt_tabular_ hydrostats_qmn.xlsx). The hydrologic-metrics and IHA-output worksheets are bundled into separate workbooks, one for the hydrologic metrics (cwt_tabular_hydmetrics.xlsx) and one for each station and parameter combination for the IHA output (gage height, sSSSSSSSS iha gmn.xlsx; discharge, sSSSSSSSS iha qmn.xlsx; where SSSSSSSS is the USGS station identification number). An IHA summary workbook is also included that contains the data for six stations that have at least 20 years of discharge record (regional_iha_cwt.xlsx). The IHA output and tabular GIS landscape data are not provided in Microsoft Access ${ }^{\circledR}$ because the structure of the output is report-formatted and therefore not compatible with the strict column-and-row format of Microsoft Access ${ }^{\circledR}$ tables. A list of the database files, tables and worksheets, and table and worksheet descriptions is included in table $4 A$. Database field names, field types, and field definitions are listed in table $4 B$. In tables $4 A-B$, table references are specific to Microsoft Access ${ }^{\circledR}$ and worksheet references are specific to Microsoft Excel ${ }^{\circledR}$. Field names and field definitions for the IHA analyses are listed in table 5, and periods of record for the IHA analyses are shown in figures 4 and 5 .
The report and database are available online at http://pubs.usgs.gov/of/2012/1026/ and is organized in the following directories and subdirectories:

$a d r \_p d f \quad$ USGS annual data-report manuscripts for active gaging stations, Adobe PDF files (referenced as appendix 1 in this report)

data all tabular data except IHA output

access $\quad$ Microsoft Access ${ }^{\circledR}$ data base files

ascii raw NWISWeb data files

excel Microsoft Excel ${ }^{\circledR}$ workbook files

geodatabase all spatial data, feature (vector) and raster datasets

cache_white_nwrs.gdb ESRI ArcGIS ${ }^{\circ}$ file geodatabase

map_package ESRI ArcReader ${ }^{\circledR}$ published map

raster ESRI ArcGRID ${ }^{\circledR}$ raster datasets

iha IHA analysis, Microsoft Excel ${ }^{\circledR}$ workbook files

plot_pdf hydrologic data plots, ADOBE PDF files (referenced as appendix 2 in this report)

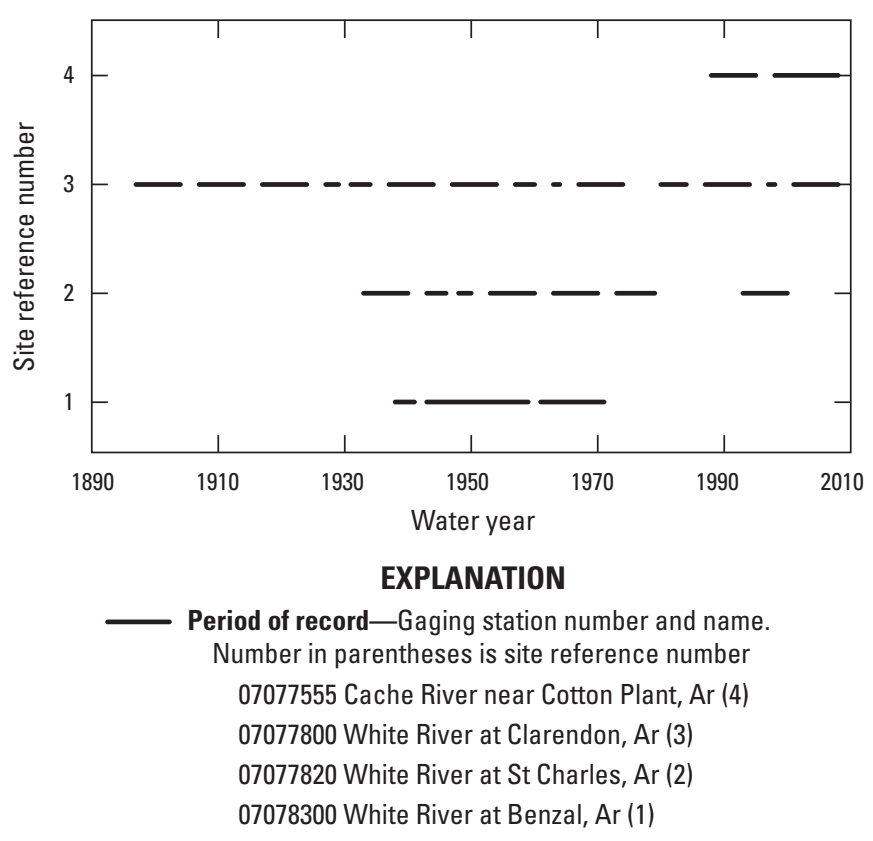

Figure 4. Periods of record for mean-daily gage-height data used in Indicators of Hydrologic Alteration analyses for gaging stations in the contributing watersheds and vicinity of the Cache and White River National Wildlife Refuges, Arkansas, Missouri, and Oklahoma. Locations of gaging stations shown in figure 1 . 


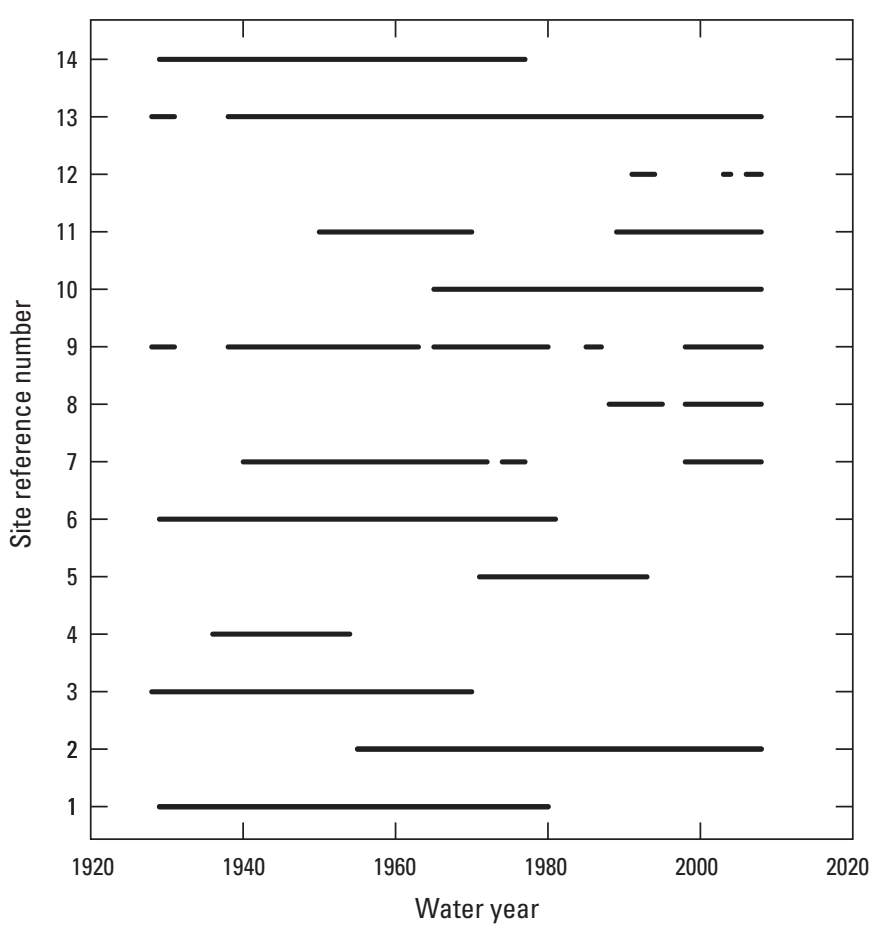

EXPLANATION

Period of record-Gaging station number and name. Number in parentheses is site reference number 07047970 Mississippi River at Helena, $\operatorname{Ar}$ (14) 07074500 White River at Newport, Ar (13) 07076750 White River at Georgetown, $\operatorname{Ar}$ (12) 07077000 White River at Devalls Bluff, $\operatorname{Ar}(11)$ 07077380 Cache River at Egypt, Ar (10) 07077500 Cache River at Patterson, Ar (9) 07077555 Cache River near Cotton Plant, Ar (8) 07077700 Bayou Deview near Morton, Ar (7) 07077800 White River at Clarendon, Ar (6) 07077950 Big Creek at Poplar Grove, Ar (5) 07078000 Lagrue Bayou near Stuttgart, $\operatorname{Ar}(4)$ 07263500 Arkansas River at Little Rock, Ar (3)

07264000 Bayou Meto near Lonoke, Ar (2) 07265450 Mississippi River near Arkansas City, Ar (1)

Figure 5. Periods of record for mean-daily discharge data used in Indicators of Hydrologic Alteration analyses for gaging stations in the contributing watersheds and vicinity of the Cache and White River National Wildlife Refuges, Arkansas, Missouri, and Oklahoma. Locations of gaging stations shown in figure 1 .

\section{Hydrologic and Landscape Data Reduction}

Hydrologic- and landscape-data reduction were done with a suite of SAS programs (SAS Institute, Inc., 2011), IHA software (The Nature Conservancy, 2009), Microsoft Access ${ }^{\circledR}$, Microsoft Excel ${ }^{\circledR}$, and ESRI ArcGIS ${ }^{\circledR}$ (ESRI, 2008). The hydrologic-data derivatives include statistical-summary data and hydrologic metrics, both based on the mean-daily values of gage height and discharge, and the IHA parameters and EFCs (Richter and others, 1996; The Nature Conservancy, 2007). The landscape-data derivatives include zonal summaries of USEPA Level III and IV ecoregions (U.S. Environmental Protection Agency, 2011), STATSGO HSGs (U.S. Department of Agriculture, 1994, 2009, 2011d), and NLCD land-cover (U.S. Geological Survey, 2008f; MultiResolution Land Characteristics Consortium [MRLC], 2011a) and land-cover-change data (Multi-Resolution Land Characteristics Consortium [MRLC], 2011b). Zonal summation was done by hydrologic subregion, hydrologic cataloging unit, and NWR land-acquisition area.

\section{Descriptive Statistics, Percentiles, and Hydroecological Metrics}

The statistical-summary tables include the basic univariate descriptive statistics, percentiles, spread and ratio measures based on the 10th, 20th, 25th, 50th, 75th, 80th, and 90th percentiles (Richards, 1989), and the coefficient of variation of the set of every 5 th log base-ten percentile (5th, 10th, 15th, ..., 85th, 90th, 95th percentiles [ $\mathrm{n}=19]$; Richards, 1989). This statistic is, along with the mean, standard deviation, and coefficient of skew of these same percentiles, also part of the statistical characterization of the standard duration curve for gage height or discharge (U.S. Geological Survey, 2011f, p. 240). Each table also includes the fraction of the summary time interval represented by daily-values data; for example, in the annual-summary tables, a value of 0.85 means that 85 percent of that year has daily values. The data-completeness measures are used to determine how much data are used in some of the statistical analyses and summary plots. The hydrologic-metrics tables include raw and normalized percentiles (normalized by the median value), measures of low-flow and high-flow duration and frequency, measures of hydrologic-event magnitude, frequency, and rateof-change, and a hydrograph flashiness index (Richards-Baker flashiness index [RBFI], field rb_flash, table 4B; McMahon and others, 2003; Baker and others, 2004). The RBFI is the absolute-value sum of the y-component of the hydrograph (absolute-value total change in gage height or discharge) normalized to the area under the hydrograph (sum gage height or discharge) and is dimensionless. The "flashier" or more responsive the hydrograph on a short time scale, the larger the numerator, and therefore, the RBFI value. The descriptive 
statistics, percentiles, and hydrologic metrics included in the database are listed and defined in table $4 B$.

There are six summary modes for the hydrologic metrics: period-of record, annual, and index period, and each of these by water year and calendar year. The period-of-record summaries are for complete years only, with the departure measures indexed to the complete-year period. The annual summaries include all years, both complete and partial record, with the departure measures indexed to each year's record. The indexperiod summaries are annual summaries with the departure measures indexed to the complete-year period. The raw-data processing, statistical reduction, calculation of hydrologic metrics, and graphical presentation were done with a suite of SAS programs (SAS Institute, Inc., 2011). The source code for these programs will be included in an appendix as a revision.

\section{Indicators of Hydrologic Alteration}

The IHA software package was developed by Richter and others (1996) and The Nature Conservancy $(2007,2009)$ to provide a tool for calculating the characteristics of natural and altered hydrologic regimes. Any type of daily hydrologic data can be used as input data for the software, typically stream discharge and gage height, but also groundwater levels, water temperature, specific conductance, dissolved oxygen, $\mathrm{pH}$, or turbidity. The application of the IHA software is explained in detail in this section of this report, as IHA was used to compute many of the statistics in the Cache and White River NWRs database. The hydroecological-flow characterization process, background and development of ecological-flow methodologies, and commonly used assessment techniques, including IHA, are discussed in detail in appendix 3.

The IHA workbooks each include six worksheets:

1. ann-median values by water year for IHA variables in IHA parameter groups 1 through 5 and EFC groups 1 through 5 (table 5);

2. sco-IHA scorecard: median values and the coefficient of dispersion (interquartile spread) for IHA parameter groups 1 through 5 and the EFC groups 1 through 5 (table 5);

3. $l s q$-linear regression models for each IHA parameter and EFC with water year;

4. pct-percentiles and the interquartile spread for IHA parameter groups 1 through 5 and EFC groups 1 through 5;

5. daily efcs - mean-daily values for the analysis period categorized by EFC group; and

6. msg-informational and(or) error messages about the IHA run. The worksheets and their contents are documented in the IHA user's manual (The Nature Conservancy, 2009).
The IHA analysis generates two groups of variables, the IHA parameter groups 1 through 5, and the EFC groups 1 through 5 (Richter and others, 1996; The Nature Conservancy, 2009; table 5). The IHA parameter groups are organized by types of statistics that provide data on the magnitude, frequency, duration, and timing of hydrologic events and data on the rate and frequency of change in hydrologic conditions. Each parameter group focuses on specific ecosystem influences that affect the availability and quality of riparian and aquatic habitat (Richter and others, 1996; The Nature Conservancy, 2009). The IHA parameter groups include the following categories: (1) magnitude of monthly water conditions, (2) magnitude and duration of annual extreme water conditions, (3) timing of annual extreme water conditions, (4) frequency and duration of high and low pulses, and (5) rate and frequency of water condition changes. There are also five EFC groups that relate hydrologic patterns to ecological function: low flows, extreme low flows, high-flow pulses, small floods, and large floods.

The IHA analysis for this database was done on complete standard water years grouped into one time period. The water year can be defined as any contiguous 12-month period but was left as the default, October 1 through September 30, for this analysis. An alternative scenario is to use two time periods if there was an abrupt alteration in the hydrologic regime such as an upstream dam closure, change in reservoir operation, or major diversion. The two periods could then be statistically compared. Either parametric (mean and standard deviation) or non-parametric (percentiles) statistics can be used to calculate the IHA parameters. The analysis for this report and database was done using non-parametric statistics.

Flow separation by EFC group can be done by either the one-parameter method or the four-parameter method. The oneparameter method classifies mean-daily values as high values if they are greater than the low-flow threshold (default value, 50th percentile) and as low values otherwise. In this analysis, the four-parameter method was used. The four-parameter method uses three passes through the data to classify meandaily values based on four thresholds: (1) high-flow threshold, default value, 75th percentile; (2) low-flow threshold, default value, 50th percentile; (3) high-flow start-rate threshold, default value, increase greater than 25 percent of the preceeding value when values are between the high-flow and low-flow thresholds; and (4) high-flow end-rate threshold, decrease greater than 10 percent of the preceeding value when values are between the high-flow and low-flow thresholds. High values are then further classified into from one-to-three high-flow classes based on two parameters, the 2-year and 10-year recurrence intervals: (1) small-flood, peak flow values greater than the 2-year recurrence interval (default value) are assigned to the small-flood class; (2) large-flood, peak flow values greater than the 10-year recurrence interval (default 
value) are assigned to the large-flood class; and (3) high-flow values that are not assigned to either of the first two classes are classified as high-flow pulses. Low-flow values less than the extreme-low-flow threshold, default value, 10th percentile of the low flows, are classified as extreme low flows. All defaultthreshold values were used for this analysis.

Although the terminology used here and elsewhere in the literature typically refers to "flow" values, the IHA analysis was done for both mean-daily gage height and mean-daily discharge record. The IHA concept could logically be extended to include the analysis of any mean-daily time series, for example, water temperature, specific conductance, or dissolved oxygen. However, the specifics of the ecological effects of the IHA parameter groups and EFC groups would change.

\section{Landscape Data}

The land-cover raster data are 30-m resolution, ESRI ArcGRID ${ }^{\circledR}$ format raster datasets (ESRI, 2011a) in the NLCD. Each of the three datasets, NLCD 1992, NLCD 2001, and 1992-2001 NLCD-LCCR, was clipped to the defined geographic extent (figs. 6-8). Zonal summations by NLCD land-cover category (U.S. Geological Survey, 2008a; Multi-Resolution Land Characteristics Consortium [MRLC], 2011a) and land-cover-change category (Fry and others, 2008) were done using the tabulate-area tool in ESRI's ArcGIS ${ }^{\circledR}$ Spatial Analyst extension (ESRI, 2011c) with hydrologic subregions (HUC4s; U.S. Department of Agriculture, 2011a), hydrologic cataloging units (8-digit HUCs; U.S. Department of Agriculture, 2011a), and refuge-acquisition boundaries (U.S. Fish and Wildlife Service, 2011e) as the zone features. Landcover-category zonal-area tabulations are provided as ESRI geodatabase tables (ESRI, 2008; table 3) and landcovercategory percentages are provided as Microsoft Excel ${ }^{\circledR}$ files (file and field descriptions in tables $4 A-B$ ).

Hydrologic soil groups A-D percentages were calculated for the hydrologic subregions and cataloging units by zonal summation of the 100-m resolution STATSGO raster dataset (U.S. Department of Agriculture, 1994, 2009, 2011b; Wolock, 1997) and reported as areal percentages of each HUC. The zonal-area tabulations are provided in ESRI geodatabase tables (table 3 ) and zonal percentages are provided in Microsoft Excel ${ }^{\circledR}$ files (tables $4 A-B$ ) and shown in figures $3 A-D$.

Percentages of the U.S. Environmental Protection Agency Level III and Level IV ecoregions (U.S. Environmental Protection Agency, 2011) were calculated for the hydrologic subregions and cataloging units by intersecting the ecoregion feature dataset with the 4-digit and 8-digit HUC boundaries. The ecoregion data summarized by subregion and cataloging unit are provided in Microsoft Excel ${ }^{\circledR}$ files (tables $4 A-B$ ).

\section{Database Summary Data}

This report includes statistical and graphical summaries of the hydrologic data, IHA summary data for gaging stations with at least 20 years of record, and zonal summaries of the NLCD land-cover and land-cover-change data. The databasesummary data serve as metadata for the database, provide a context for hydrologic analysis, and can help database users determine which data are suitable for answering specific NWR hydrologic questions.

\section{Hydrologic Statistical Summary}

A station-level summary of the hydrologic data by both water year and calendar year is presented in tables 6-9. The primary purpose of these summary tables is to provide database users with information on the quantity and quality of available data, facilitate comparisons between stations, and provide a benchmark for evaluating current hydrologic conditions within the context of the long-term record. Tables $6 A$ (water-year) and $6 B$ (calendar-year) summarize the mean-annual and mean-daily gage-height values for each gaging station. The mean, minimum, and maximum values, and the 5th, 10th, 25th, 50th, 75th, 90th, and 95th percentiles are given for mean-annual gage height; and the minimum and maximum and the same percentiles are also given for meandaily gage height. The water or calendar year is indicated for the minimum and maximum values for mean-annual and mean-daily discharge - the driest and wettest years on record for each station. Percentiles are not given if there are insufficient data. Data requirements for percentiles are as follows: 50th, $>1$ observation; 25th, 75th, $>4$ observations; 10th, 90th, $>10$ observations; and 5th, 95 th, $>20$ observations; in this case, observations represent the number of complete years of record. Tables $7 A$ (water-year) and $7 B$ (calendar-year) present the same data for discharge, with the addition of long-term yield. Tables $8 A$ (water-year) and $8 B$ (calendar-year) summarize selected hydrologic metrics for mean-daily gage-height values for each gaging station. Period-of-record median and mean values are given for (1) the coefficient of variation of the set of every 5 th $\log$ base-ten percentile of discharge (LCV5), (2) the 75th-25th (7525), 80th-20th (8020), and 90th-10th (9010) spread and ratio measures (Richards, 1989; table 4), (3) five flow-magnitude/flow-duration metrics: cum_50, rise 50, risedur_50, fall_50, and falldur_50-(tables $4 A-B$; McMahon and others, 2003), and (4) the Richards-Baker flashiness index (RBFI) (tables $4 A-B$; Baker and others, 2004). Tables $9 A$ (water-year) and $9 B$ (calendar-year) present the same data for discharge. 
When comparing data across stations, either for a regional analysis or for the purpose of characterizing downstream changes in hydrologic patterns, attention must be given to ensuring that there are sufficient coincident data to validate the analysis. It is suggested that interpretation be restricted to stations and time periods that include at least 90 percent coincident data. However, it is recognized that the completeness criteria used in hydrologic analysis are operationally defined, and therefore both the level of potential error in analysis and interpretation of results are affected by the overall quantity and spatiotemporal distribution of missing data.

\section{Hydrologic Graphical Summary}

Table 10 lists the plots available for each gaging station with links to downloadable Adobe PDF files in appendix 2 (the plot_pdf directory of the database) available online at http://pubs.usgs.gov/of/2012/1026. For the links in table 10 to be active, the plot_pdf zip archive needs to be downloaded and expanded to the same folder or directory with the report PDF. Up to eight possible plots for each station-parameter combination (gage height or discharge) are shown, depending on how much data are available, with plots A1-A4 on page one and plots A5-A8 on page two of each plot file. Meandaily values for gage height and discharge are plotted in both arithmetic and log-10 space if all the values are positive. If a station record has zero and(or) negative values, only arithmetic plots are presented. Arithmetic plots and log-10 plots are provided in separate files. Plot A1 is the mean-daily-values hydrograph for the period-of record. Plot A2 is a boxplot interpolation (box-and-whisker plot) of the mean-daily values on a calendar-year annual timestep for greater-than-90-percent complete years. The data-completeness requirement can be adjusted downward, however, depending on the acceptable level of error and the degree to which the partial year represents a complete year. This adjustment potentially would generate more plots and provide a more complete temporal record. Plot A3 is a boxplot interpolation on a calendar-year decadal timestep for greater-than-90-percent complete decades. Plot A4 is a boxplot interpolation on a period-ofrecord monthly timestep for complete years and, therefore, is a summary of the long-term monthly seasonality. Plot A5 shows the 75-25, 80-20, and 90-10 spread measures, plot A6 shows the $75 / 25,80 / 20$, and 90/10 ratio measures, and plot $A 7$ shows the LCV5 and RBFI values. Plots A5-A7 each use a calendar-year annual timestep for complete years. Plot A8 is a line plot of the 10th, 25th, 50th, 75th, and 90th percentiles on a period-of-record daily timestep for complete calendar years and, therefore, is a summary of the long-term daily seasonality. Plot A8 is generated for stations that have at least two complete years of record with percentiles plotted based on the number of complete years of record: 50th percentile, $>1$ year; 25 th and 75th percentiles, $>4$ years; and 10th and 90th percentiles, $>10$ complete years of record. For cross-reference with the data, each plot lists the database table(s) that contain(s) the data being displayed and database field(s) being plotted.
An explanation file that documents the terminology, symbols, and abbreviations used in the plots is available as a downloadable Adobe PDF file (the plot_pdf directory of the database) available online at $h t t p: / / p u b s . u s g s . g o v / o f / 2012 / 1026$.

\section{Indicators of Hydrologic Alteration Interstation Comparison}

The IHA summary data for six stations in close proximity to both refuges and with at least 20 years of discharge record are included in a separate Microsoft Excel ${ }^{\circledR}$ workbook as a regional analysis where the data are presented in downstream order (tables $4 A$ and 5; file, regional_iha_cwt.xlsx). These stations are 07077000 (White R at Devalls Bluff, AR), 07077380 (Cache River at Egypt, AR), 07077500 (Cache River at Patterson, AR), 07077555 (Cache River near Cotton Plant, AR), 07077700 (Bayou DeView near Morton, AR), and 07077800 (White River at Clarendon, AR) (fig. 1, table $2 A$ ). The IHA output has been reorganized in this workbook to facilitate interstation comparisons. The regional IHA workbook contains the following worksheets: 5 each for the 1-, 3-, 7-, 30-, and 90-day-mean minimum and maximum values, 1 with the baseflow-index values, 1 with a plot of the 75th-25th percentile spread measure, a summary worksheet, and 1 for each station with the complete IHA analysis for that station included (tables $4 A$ and 5).

\section{Landscape GIS Data Layers}

Figures 6-8 and tables 11-13 present the land-cover and land-use data for the geographic extent based on the 1992 NLCD, 2001 NLCD, and 1992-2001 NLCD-LCCR datasets (U.S. Geological Survey, 2008a; Multi-Resolution Land Characteristics Consortium [MRLC], 2011a, b). These datasets are 30-m resolution raster data. The classification models used for the 1992 and 2001 datasets changed for some of the categories, so direct comparisons of the datasets cannot be made without incurring some level of error at large map scales. For this reason, the 1992-2001 NLCD-LCCR dataset was developed to facilitate more accurate comparison at a modified Anderson-level-1 classification developed for the 2001 NLCD (Anderson and others, 1976; Multi-Resolution Land Characteristics Consortium [MRLC], 2011a): 1, water; 2, urban; 3, barren; 4, forest; 5 , grassland; 6 , agriculture; and 7, wetland. The 1992-2001 NLCD-LCCR has 48 change categories, 7 with stable land cover (no change), and 42 potential categories indicating land-cover change from each category to one of the other 6 categories (Fry and others, 2008). Errors generated by direct comparison are reduced at smaller map scales (broader areas). Land-cover and land-use percentages derived from the 1992 NLCD and 2001 NLCD data are summarized by hydrologic subregion and hydrologic cataloging unit in tables 11 and 12 . The land-cover change percentages derived from 1992-2001 NLCD-LCCR are presented in table 13 . 


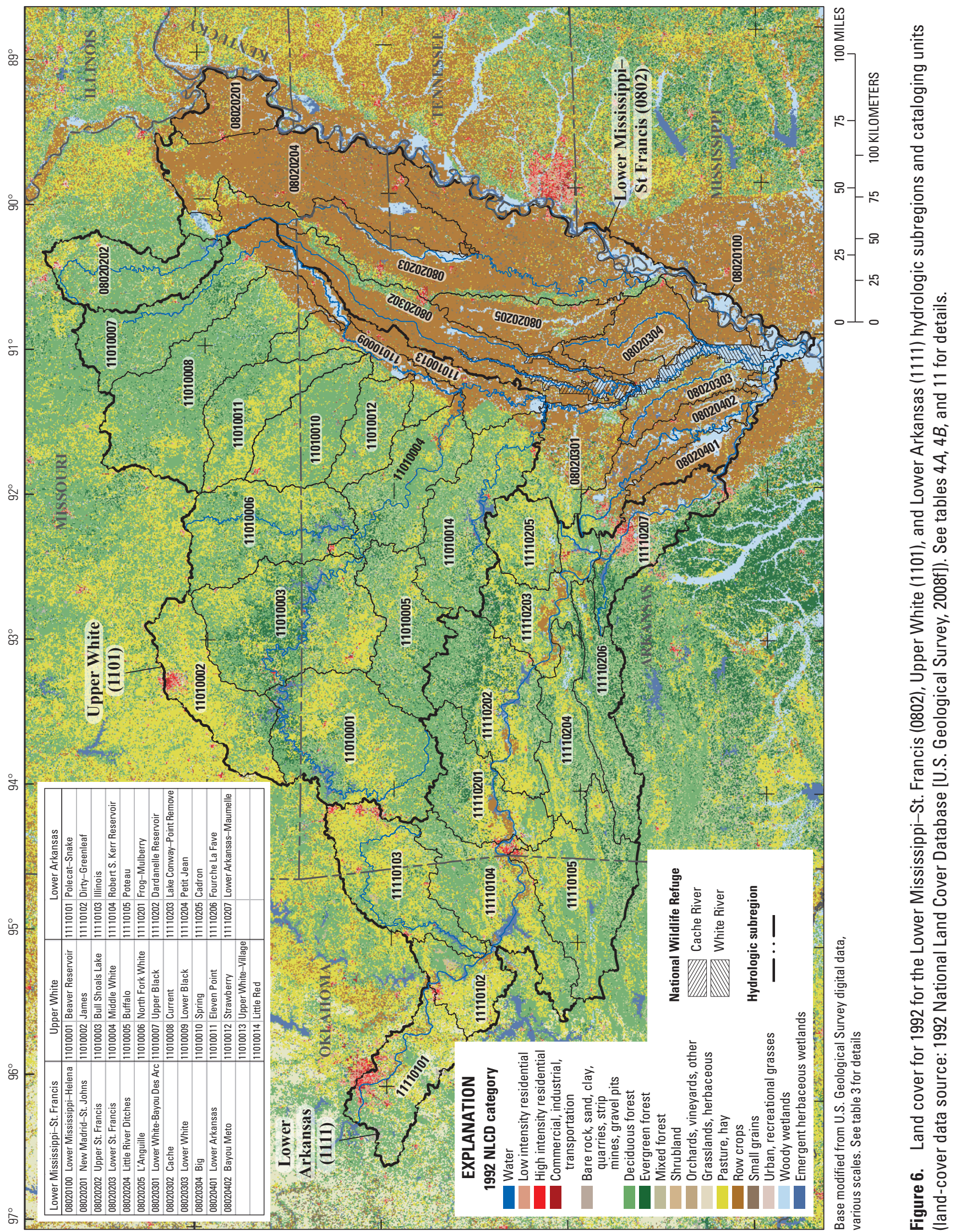




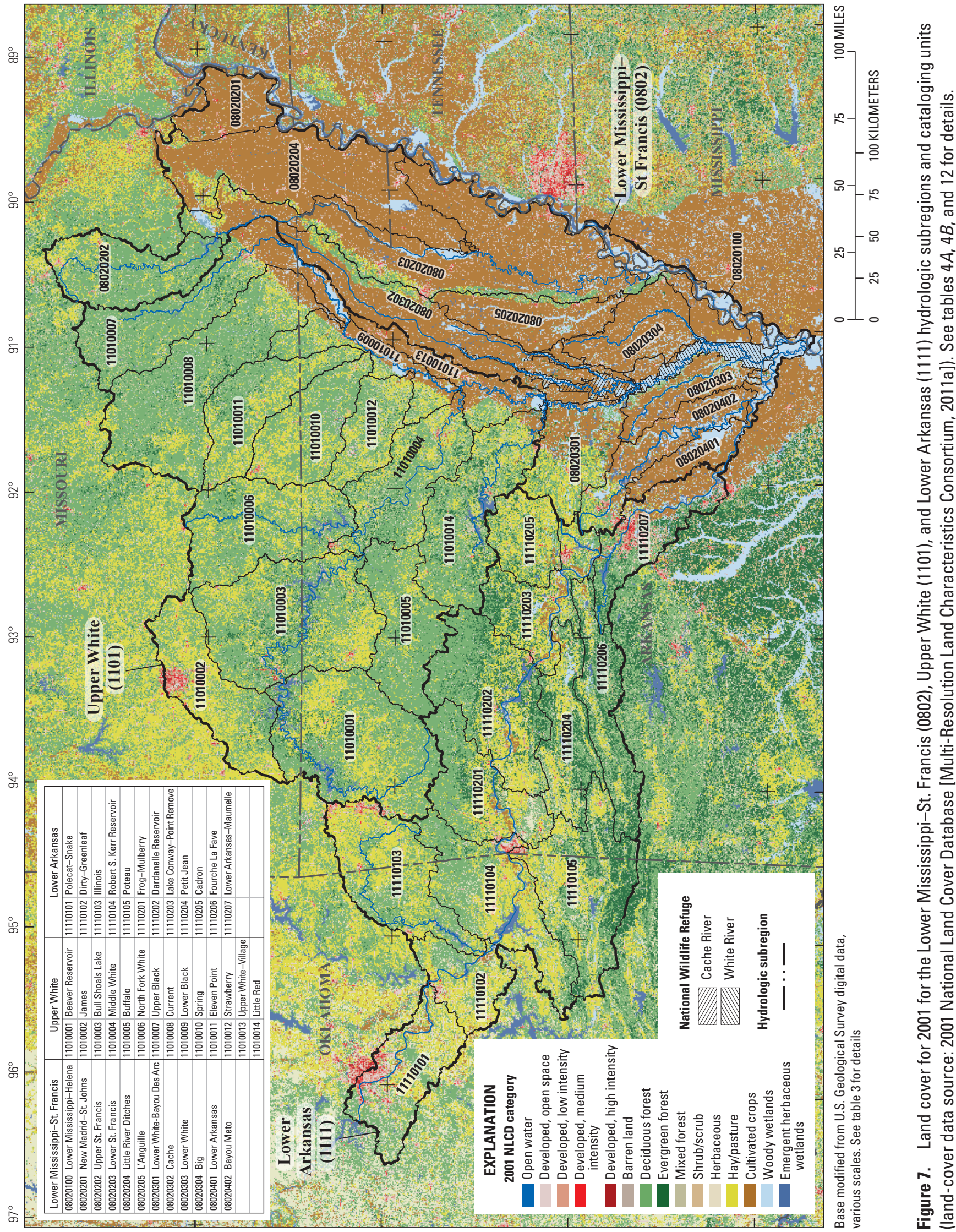




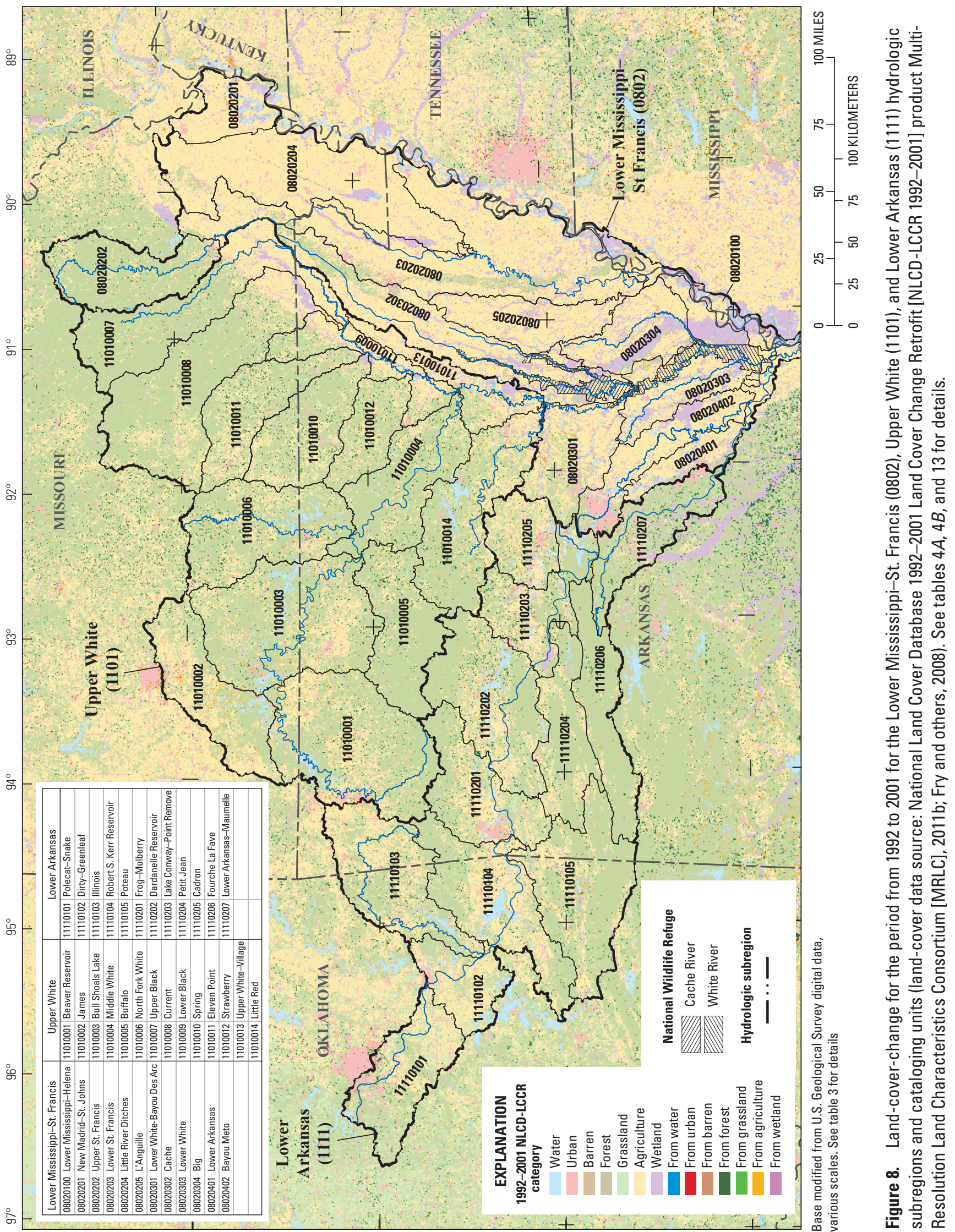




\section{Summary}

This open-file report documents the development, use, and context of a hydrologic and landscape database for the Cache River and White River National Wildlife Refuges (NWRs) and their contributing watersheds in Arkansas, Missouri, and Oklahoma. The contributing watersheds of the Cache and White River NWRs, as defined in this report, include three hydrologic subregions: Lower MississippiSt Francis $\left(16,840\right.$ square miles $\left.\left[\mathrm{mi}^{2}\right]\right)$, Upper White $\left(22,350 \mathrm{mi}^{2}\right)$, and Lower Arkansas $\left(15,830 \mathrm{mi}^{2}\right)$. Activities throughout these subregions, particularly reservoir operations, discharges, withdrawals, diversions, and dredging, all have the potential to either directly or indirectly impact the refuges. The refuges are located in the lower part of the Lower MississippiSt Francis subregion, most of which is in the Mississippi Alluvial Plain Level III ecoregion.

The hydrologic and landscape database for the Cache and White River NWRs was developed by the U.S. Geological Survey (USGS) in cooperation with the U.S. Fish and Wildlife Service (USFWS) to provide an assessment and evaluation tool for the refuge manager and USFWS scientific and technical staff to use in examining refuge-specific hydrologic patterns and trends as related to water availability for refuge ecosystems, habitats, and target species. For example, the database and this report should provide an important source of information to support water resources inventories currently underway (for White River NWR) or planned (for Cache River NWR) as part of a comprehensive national inventory and assessment of water resources at all 550-plus refuges in the NWR system initiated by USFWS in 2010. The database includes hydrologic time-series data, statistics, and hydroecological metrics that can be used to assess refuge hydrologic conditions and the availability of aquatic and riparian habitat, as well as landscape spatial data that describe the refuge environmental setting and the locations of hydrologic-datacollection stations. The procedures used to retrieve, manage, and analyze the hydrologic data, and construct and package the hydrologic and landscape database, have been automated to facilitate periodic database updates.

The hydrologic and landscape database for the Cache and White River NWRs was developed from hydrologic data retrieved from the USGS NWISWeb database and U.S. Army Corps of Engineers (USACE) digital files and landscape geographic information system (GIS) data from multiple sources. Gaging stations were selected within the geographic extent and limited to those stations that were close enough to the refuges, either upstream, downstream, or within the refuge boundary, or on nearby streams and rivers that are hydrologically connected, to provide hydrologically relevant data. Hydrologic data collected at 18 gaging stations are included in the database. Data management and data reduction were done with a suite of Statistical Analysis System programs, Indicators of Hydrologic Alteration (IHA) software, Microsoft Access ${ }^{\circledR}$, Microsoft Excel ${ }^{\circledR}$, and Environmental Systems Research Institute ArcGIS $\AA$. The tabular data include the raw daily-values data for gage height and discharge, statisticalsummary data, selected hydrologic metrics, and the IHA parameters and Environmental Flow Components (EFCs). Landscape data include GIS layers for land cover, soil hydrologic characteristics, physipographic features, geographic and hydrographic boundaries, hydrographic features, regional runoff estimates, and gaging-station locations.

A station-level summary of the hydrologic data by both water year and calendar year is included with the database to provide database users with information on the quantity and quality of available data, facilitate comparisons between stations, and provide a benchmark for evaluating current hydrologic conditions within the context of the long-term record.

The primary purpose of this report and database is for hydrologic characterization and analysis to support refuge management of riparian and instream resources. Additionally, the data can also be used as input to any of the numerous software packages available for hydrologic characterization, instream-flow assessment, and the development of environmental-flow criteria. Example applications include: (1) IHA analyses could be run with different criteria than those used for the IHA parameters and EFCs included in this database; (2) the mean-daily values - gage height and(or) discharge - could be used as input to the hydrologic characterization for an Instream Flow Incremental Methodology (IFIM) study (phases II and III, study planning, study implementation); and (3) the mean-daily discharge values and peak-flow values could be used as input to the development of a Hydroecological Integrity (Assessment) Process model. 


\section{References Cited}

Anderson, J.R., Hardy, E.E., Roach, J.T., and Witmer, R.E., 1976, A land use and land cover classification system for use with remote sensor data: U.S. Geological Survey Professional Paper 964, 28 p.

Annear, T.C. and Dey, P.D., 2006, Water management 5-year plan-2006 to 2010: Fish Division Administrative Report AW-SW-EP1-540, Wyoming Game and Fish Department, accessed November 17, 2008, at http://gf.state.wy.us/ downloads/pdf/Fish/5yearplan2006.pdf.

Arkansas Highway and Transportation Department, 2011, Arkansas cities: Accessed April 19, 2011, at http://www. geostor.arkansas.gov/G6/Home.html?id=1e4ac0a30bf74bbf c90af81180b36265.

Arkansas Natural Resources Commission, 2007, White River allocation plan, Technical analysis, Supplemental report (draft), $13 \mathrm{p}$.

Arkansas Natural Resources Commission, 2009, White River minimum streamflow, Supplemental report and staff recommendations, $7 \mathrm{p}$.

Arkansas Natural Resources Commission, 2011, Arkansas ground-water protection and management report for 2010: Accessed March 23, 2011, at http://www.anrc.arkansas. gov/groundwater/2010_gw_report.pdf.

Arkansas Soil and Water Conservation Commission, 2000, White River allocation, Bull Shoals Dam to the Mississippi River, Technical analysis (draft), 109 p.

Arkansas Studies Institute, 2011, The encyclopedia of Arkansas history and culture: Accessed June 22, 2011, at http://encyclopediaofarkansas.net/.

Armstrong, D.S., Parker, G.W., and Richards, T.A., 2008, Characteristics and classification of least altered streamflows in Massachusetts: U.S. Geological Survey Scientific Investigations Report 2007-5291, 113 p., plus CD-ROM.

Baker, D.B., Richards, Peter, Loftus, T.T., and Kramer, J.W., 2004, A new flashiness index: characteristics and applications to midwestern rivers and streams: Journal of the American Water Resources Association, v. 40, p. 503-522.

Bovee, K.D, 1982, A guide to stream habitat analysis using the instream flow incremental methodology: U.S. Fish and Wildlife Service Instream Flow Information Paper No. 12., FWS/OBS-82/26, Washington, D.C.

Bovee, K.D., Lamb, B.L., Bartholow, J.M., Stalnaker, C.B., Taylor, Jonathan, and Henriksen, Jim, 1998, Stream habitat analysis using the Instream Flow Incremental Methodology: U.S. Geological Survey Information and Technology Report 1998-2004, 139 p., accessed March 24, 2011, at http://www. fort.usgs.gov/Products/Publications/3910/3910.pdf.
Buell, G.R., Calhoun, D.L., and Wehmeyer, L.L., 2009, Hydrologic and land-use/land-cover metrics used in ecological assessments of six U.S. Fish and Wildlife Service National Wildlife Refuges in the southeastern USA, in Proceedings of the 2009 Georgia Water Resources Conference, April 27-29, 2009, Athens, Georgia, 8 p., accessed April 4, 2011, at http://www.gwri.gatech.edu/conferences/ previous-gwrc-conferences/gwrc-2009.html.

Czarnecki, J.B., 2010, Groundwater-flow assessment of the Mississippi River Valley alluvial aquifer of northeastern Arkansas: U.S. Geological Survey Scientific Investigations Report 2010-5210, 33 p.

Daly, C., 2002, Climate division normals derived from topographicallysensitive climate grids, in Proceedings of the 13th AMS Conference on Applied Climatology, American Meteorological Society, Portland, OR, May 13-16, 2002, p. $177-180$.

Dey, P.D. and Annear, T.C., 2006, Rock Creek, tributary to Medicine Bow River, instream flow studies: Fish Division Administrative Report AW-LE-5UM-511, Wyoming Game and Fish Department, accessed November 17, 2008, at http://gf.state.wy.us/downloads/pdf/Fish/RockCk2.pdf.

ESRI, 2008, ArcGIS 9-What is ArcGIS 9.3?: ArcGIS Resource Center, ESRI Software 9.3 LibraryWhat is ArcGIS?, 131 p., accessed March 2, 2011, at http://resources.arcgis.com/content/productdocumentation $?$ fa $=$ viewDoc\& $P I D=43 \&$ MetaID $=1405$.

ESRI, 2011a, ESRI Grid format: ArcGIS Resource Center, Desktop 10: Accessed March 2, 2011, at http://help.arcgis. com/en/arcgisdesktop/10.0/help/index.html\#/ESRI_Grid_ format/009t0000000w000000/.

ESRI, 2011b, Documentation for ArcReader: Accessed July 5, 2011, at http://support.esri.com/en/knowledgebase/ product-documentation/list/productid/18.

ESRI, 2011c, Documentation for ArcGIS spatial analyst: Accessed February 16, 2011 at http://resources.arcgis.com/ content/product-documentation? fa $=$ listDocs \& $P I D=47$.

Falcone, J.A., Carlisle, D.M., Wolock, D.M., and Meador, M.R., 2010, GAGES - A stream gage database for evaluating natural and altered flow conditions in the conterminous United States: Ecology v. 91, p. 621; Data Paper in Ecological Archives E091-045-D1; available online at http://esapubs.org/Archive/ecol/E091/045/default.htm.

Flyways.us, 2011, The Mississippi flyway council: A collaborative effort of waterfowl managers across the continent, accessed February 7, 2011, at http://mississippi.flyways.us/.

Fry, J.A., Coan, M.J., Homer, C.G., Meyer, D.K., and Wickham, J.D., 2008, Completion of the National Land Cover Database (NLCD) 1992-2001 land cover change retrofit product: U.S. Geological Survey Open-File Report 2008-1379, 24 p., available online at http://pubs. usgs.gov/of/2008/1379/. 
Gebert, W.A., Graczyk, D.J., and Krug, W.R., 1987, Average annual runoff in the United States, 1951-80: U.S. Geological Survey Hydrologic Investigations Atlas HA-710, scale 1:7,500,000, accessed March 21, 2011, at http://water.usgs. gov/GIS/metadata/usgswrd/XML/runoff.xml\#stdorder.

Gibson, W.P., Daly, C., Kittel, T., Nychka, D., Johns, C., Rosenbloom, N., McNab, A., and Taylor, G., 2002, Development of a 103-year high-resolution climate data set for the conterminous United States, in Proceedings of the 13th AMS Conference on Applied Climatology, American Meteorological Society, Portland, OR, May 13-16, 2002, p. 181-183, accessed March 21, 2011, at http://www1.ncdc. noaa.gov/pub/data/prism100/.

Gillilan, D. and Brown, T., 1997, Instream flow protectionSeeking a balance in western water use: Washington, D.C., Island Press, $427 \mathrm{p}$.

Henriksen, J.A, Heasley, J., Kennen, J.G., and Nieswand, S., 2006, Users' manual for the hydroecological integrity assessment process software (including the New Jersey assessment tools): U.S. Geological Survey Open-File Report 2006-1093, 71 p., accessed November 18, 2008, at http://www.fort.usgs.gov/Products/Publications/pub_ abstract.asp? PubID $=21598$.

Hobbs, Walter V., 2011, RDB-A relational database management system: Accessed April 5, 2011, at http://compbio.soe. ucsc.edu/rdb/.

Hoyt, J.C. and Wood, B.D., 1905, Index to the hydrographic progress reports of the United States Geological Survey, 1888 to 1903: U.S. Geological Survey Water-Supply and Irrigation Paper No. 119, Washington, D.C., 111 p.

Kennen, J.G., Henriksen, J.A., and Nieswand, S.P., 2007, Development of the hydroecological integrity assessment process for determining environmental flows for New Jersey streams: U.S. Geological Survey Scientific Investigations Report 2007-5206, 55 p., accessed March 25, 2011, at http://pubs.usgs.gov/sir/2007/5206/.

Kiesling, Richard L., 2003, Applying indicators of hydrologic alteration to Texas streams-Overview of methods with examples from the Trinity River Basin: U.S. Geological Survey Fact Sheet 128-03, accessed March 11, 2011, at http://pubs.usgs.gov/fs/fs12803/.

McMahon, G., Bales, J.D., Coles, J.F., Giddings, E.M.P. and Zappia, H., 2003, Use of stage data to characterize hydrologic conditions in an urbanizing environment: Journal of the American Water Resource Association, v. 39 , p. $1529-1546$.

Microsoft, 2011, Microsoft Download Center: Excel Viewer: Accessed July 5, 2011, at http://www.microsoft.com/ download/en/details.aspx?id $=10$.
Milhous, R.T., Updike, M.A., and Schneider, D.M., 1989, Physical habitat simulation reference manual-Version II: U.S. Fish and Wildlife Service Biological Report 89(16) (Instream Flow Information Paper No. 26), Washington D.C., 403 p., accessed March 25, 2011, at http://www.fort.usgs. gov/Products/Publications/3912/3912.pdf.

Multi-Resolution Land Characteristics Consortium (MRLC), 2011a, National Land Cover Database 2001 (NLCD 2001): Accessed February 14, 2011, at http://www.mrlc.gov/nlcd.php.

Multi-Resolution Land Characteristics Consortium (MRLC), 2011b, National Land Cover Database 1992-2001 Land Cover Change Retrofit (NLCD-LCCR 1992-2001) product: Accessed February 14, 2011, at http://www.mrlc.gov/ changeproduct.php.

National Oceanic and Atmospheric Administration, 2011, NOAA's coastal geospatial data project: GIS filesDownload: Accessed February 14, 2011, at http://coastal geospatial.noaa.gov/data_gis.html.

Olden, J.D. and Poff, N.L., 2003, Redundancy and the choice of hydrologic indices for characterizing streamflow regimes: River Research and Applications, v. 19, p. 101-121.

Omernik, J.M., 1987, Ecoregions of the conterminous United States-Map, scale 1:7,500,000: Annals of the Association of American Geographers, v. 77, p. 118-125.

OpenOffice.org ${ }^{\mathrm{TM}}, 2011$, OpenOffice.org ${ }^{\mathrm{TM}}$ - The free and open productivity suite: Accessed July 5, 2011, at http://www.openoffice.org/.

Poff, N.L., 1996, A hydrogeography of unregulated streams in the United States and an examination of scaledependence in some hydrological descriptors: Freshwater Biology, v. 36, p. 71-91.

Ramsar, 2011, The Ramsar Convention on Wetlands: Convention on wetlands of international importance especially as waterfowl habitat, accessed February 4, 2011, at http://www.ramsar.org/.

Reed, T.B., 2003, Recalibration of a ground-water flow model of the Mississippi River Valley Alluvial Aquifer of northeastern Arkansas, 1918-1998, with simulations of water levels caused by projected ground-water withdrawals through 2049: U.S. Geological Survey Water-Resources Investigations Report 03-4109, 63 p.

Richards, R.P., 1989, Measures of flow variability for Great Lakes tributaries: Environmental Monitoring and Assessment, v. 12, p. 361-377.

Richter, B.D., Baumgartner, J.V., Powell, J., and Braun, D.P., 1996, A method for assessing hydrologic alteration within ecosystems: Conservation Biology, v. 10, p. 1163-1174. 
SAS Institute Inc., 2011, SAS product documentation, Cary, NC: SAS Institute Inc., accessed February 15, 2011, at http://support.sas.com/documentation/index.html.

Schrader, T.P., 2009, Water levels and selected water-quality conditions in the Spart-Memphis aquifer (Middle Claiborne aquifer) in Arkansas, spring-summer 2007: U.S. Geological Survey Scientific Investigations Report 2009-5207, 50 p., available online at http://pubs.usgs.gov/sir/2009/5207/.

Schrader, T.P., 2010, Water levels and selected water-quality conditions in the Mississippi River Valley alluvial aquifer in eastern Arkansas, 2008: U.S. Geological Survey Scientific Investigations Report 2010-5140, 71 p., 2 plates, available online at http://pubs.usgs.gov/sir/2010/5140/.

Seaber, P.R., Kapinos, F.P., and Knapp, G.L., 1994, Hydrologic unit maps: U.S. Geological Survey Water-Supply Paper 2294, 66 p.

Smith, P., 1998, Setting instream flows in Washington State: Publication \#98-1813-WR, Washington State Department of Ecology, accessed November 17, 2008, at http://www.ecy. wa.gov/biblio/981813wr.html.

Soil Survey Staff, 2011, U.S. general soil map (STATSGO2): U.S. Department of Agriculture, Natural Resources Conservation Service, accessed March 1, 2011, at http://soils.usda. gov/survey/geography/statsgo/.

Tennessee Spatial Data Server, 2011, Frequently-accessed data layers-City limits: Accessed April 19, 2011, at http://www. tngis.org/frequently_accessed_data.html.

The Nature Conservancy, 2007, Indicators of hydrologic alteration-IHA software: Accessed February 11, 2011, at http://conserveonline.org/workspaces/iha/.

The Nature Conservancy, 2009, Indicators of hydrologic alteration, Version 7.1, User's manual: The Nature Conservancy with rPurview LLC-Ted Rybicki, Totten Software Design, Smythe Scientific Software, 81 p., accessed March 10, 2011, at http://conserveonline.org/ workspaces/iha/documents/download/view.html.

URS, 2004, Phase 1 repor-White River navigation improvement project: Recreation benefits study: Prepared for U.S. Army Corps of Engineers, Memphis District: Gaithersburg, Maryland and Metarie, Louisiana, URS Group, Inc., Contract Number DACW66-01-D-0005, 103 p.

U.S. Army Corps of Engineers, 1999, Eastern Arkansas region comprehensive study; Grand Prairie region and Bayou Meto Basin; Grand Prairie area demonstration project; general re-evaluation report: Volume 1-Main report and final environmental impact statement (FEIS): U.S. Army Corps of Engineers, Memphis District, Mississippi River Commission, $427 \mathrm{p}$.
U.S. Army Corps of Engineers, 2003, Summary report of the preliminary draft White River navigation general reevaluation report: U.S. Army Corps of Engineers, Memphis District, $79 \mathrm{p}$.

U.S. Army Corps of Engineers, 2009, Project review planWhite River navigation improvement project from the Arkansas Post Canal to Newport, Arkansas section 363, general re-evaluation: U.S. Army Corps of Engineers, Memphis District, 16 p.

U.S. Army Corps of Engineers, 2011a, McClellan-Kerr Arkansas River Navigation System (MKARNS): Accessed February 7, 2011, at http://www.swl.usace.army.mil/ navigation/mckarns.html.

U.S. Army Corps of Engineers, 2011b, Grand Prairie Area Demonstration Project: Accessed February 8, 2011, at http://www.mvm.usace.army.mil/grandprairie/.

U.S. Army Corps of Engineers, 2011c, White River fact sheet: Accessed February 10, 2011, at http://www.mvm.usace. army.mil/whiteriver/FactSheet/WRNavApr01\%20.htm.

U.S. Army Corps of Engineers, 2011d, Corps Lakes Gateway: Accessed June 22, 2011, at http://corpslakes.usace.army. mil/visitors/visitors.cfm.

U.S. Army Corps of Engineers, 2011e, Rivergages.comWater levels of rivers and lakes, accessed February 14, 2011, at http://www2.mvr.usace.army.mil/WaterControl/new/ layout.cfm.

U.S. Census Bureau, 2011a, USA Counties ${ }^{\mathrm{TM}}$ : Accessed June 24, 2011, at http://censtats.census.gov/usa/usa.shtml.

U.S. Census Bureau, 2011b, 2010 Census TIGER/Line Shapefiles: Accessed February 14, 2011, at http://www.census. gov/geo/www/tiger/tgrshp2010/tgrshp2010.html.

U.S. Department of Agriculture, 1994, State soil geographic (STATSGO) data base--Data use information: Natural Resources Conservation Service, National Soil Survey Center, Miscellaneous Publication Number 1492, 113 p., accessed March 1, 2011, at http://www.nrcs.usda.gov/ technical/techtools/statsgo_db.pdf.

U.S. Department of Agriculture, 2009, Hydrologic soil groups, Chapter 7 in National Engineering Handbook, Part 630, Hydrology: Natural Resources Conservation Service, 210-VI-NEH, 13 p., accessed February 28, 2011, at http://policy.nrcs.usda.gov/.

U.S. Department of Agriculture, 2011a, Watershed boundary dataset (WBD): Natural Resources Conservation Service, accessed February 11, 2011, at http://www.nrcs.usda. gov/wps/portal/nrcs/detail/national/water/watersheds/. 
U.S. Department of Agriculture, 2011b, eDirectives-Electronic directives system: Natural Resources Conservation Service,

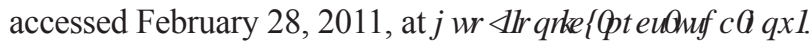

U.S. Department of Agriculture, 2011c, Grand Prairie Irrigation Project: Accessed April 21, 2011, at http://www.ar.nrcs. usda.gov/programs/grand_prairie.html.

U.S. Department of Agriculture, 2011d, U.S. General Soil Map (STATSGO2): Accessed July 19, 2011, at http://soils. usda.gov/survey/geography/statsgo/.

U.S. Environmental Protection Agency, 2011, Level III and Level IV ecoregions of the continental United States: Western Ecology Division, accessed March 1, 2011, at http://www.epa.gov/wed/pages/ecoregions/level_iii_iv. htm \#LevelIV.

U.S. Fish and Wildlife Service, 2011a, Cache River National Wildlife Refuge: Accessed February 4, 2011, at $h t t p: / / w w w . f w s . g o v / c a c h e r i v e r /$.

U.S. Fish and Wildlife Service, 2011b, White River National Wildlife Refuge: Accessed February 4, 2011, at $h t t p: / / w w w . f w s . g o v / w h i t e r i v e r /$.

U.S. Fish and Wildlife Service, 2011c, Water resources survey gets underway: Refuge Update, January/February 2011, v. 8, no. 1, 24 p., accessed March 24, 2011, at http://www.fws. gov/refuges/RefugeUpdate/pdfs/refUp_JanFeb_2011.pdf.

U.S. Fish and Wildlife Service, 2011d, National Wildlife Refuge system: Accessed September 30, 2011, at http://www.fws.gov/refuges/.

U.S. Fish and Wildlife Service, 2011e, USFWS national cadastral data-National Wildlife Refuge and Hatchery boundaries: Geospatial Services, Information Resources and Technology Management, Cadastral Data Working Group, accessed March 1, 2011, at http://www.fws.gov/GIS/data/ CadastralDB/index.htm.

U.S. Geological Survey, 2002, NWISWeb-New site for the Nation's water data: U.S. Geological Survey Fact Sheet FS-128-02, 2 p.

U.S. Geological Survey, 2007a, Facing tomorrow's challengesU.S. Geological Survey science in the decade 2007-2017: U.S. Geological Survey Circular 1309, 81 p., accessed September 27, 2011, at http://pubs.usgs.gov/circ/2007/1309/.

U.S. Geological Survey, 2007b, Facing tomorrow's challengesU.S. Geological Survey science in the decade 2007-2017: Understanding ecosystems and predicting ecosystem change: U.S. Geological Survey Fact Sheet 2007-3107, 2 p., accessed September 27, 2011, at http://pubs.usgs.gov/ $f_{s} / 2007 / 3107 /$.

U.S. Geological Survey, 2008a, National Land Cover Database 1992 (NLCD 1992): Accessed November 19, 2008, at http://landcover.usgs.gov/natllandcover.php.
U.S. Geological Survey, 2008b, Historical backdrop to IFIM: Accessed November 17, 2008, at http://www.fort.usgs.gov/ Products/Software/ifim/history.asp.

U.S. Geological Survey, 2008c, The five phases of IFIM: Accessed November 17, 2008, at http://www.fort.usgs.gov/ Products/Software/ifim/5phases.asp.

U.S. Geological Survey, 2008d, Physical habitat simulation (PHABSIM) software: Accessed November 17, 2008 at http://www.fort.usgs.gov/Products/Software/PHABSIM.

U.S. Geological Survey, 2008e, National hydrologic assessment tool (NATHAT): Accessed November 18, 2008, at http://www.fort.usgs.gov/Products/Software/NATHAT/.

U.S. Geological Survey, 2008f, "HIP" new software-The hydroloecological integrity assessment process: Accessed November 18, 2008, at http://www.fort.usgs.gov/Resources/ research_briefs/HIP.asp.

U.S. Geological Survey, 2011a, National Water Information System (NWIS): Accessed February 11, 2011, at http://pubs.usgs.gov/fs/FS-027-98/.

U.S. Geological Survey, 2011b, USGS water data for the Nation-National Water Information System: Web interface (NWISWeb), accessed February 11, 2011, at $h t t p: / / w a t e r d a t a . u s g s . g o v / u s a / n w i s / n w i s$.

U.S. Geological Survey, 2011c, NWISWeb-New site for the Nation's water data: Accessed February 11, 2011, at http://pubs.usgs.gov/fs/fs-128-02/.

U.S. Geological Survey, 2011d, Water-data reports: Accessed July 7, 2011, at http://pubs.usgs.gov/wdr/.

U.S. Geological Survey, 2011e, National hydrography dataset: Accessed February 14, 2011, at http://nhd.usgs.gov/.

U.S. Geological Survey, 2011f, User's manual for the National Water Information System of the United States Geological Survey: Automated data processing system (ADAPS), version 4.10, p. 487, accessed September 12, 2011, at http://nwis.usgs.gov/nwisdocs4_10/adaps/adaps.book.html.

U.S. Geological Survey, 2011g, New Jersey hydrologic tools (NJHAT and NJSCT): Accessed March 30, 2011, at http:// www.fort.usgs.gov/Products/Software/NJHAT/Default.asp.

Waddle, T.J. ed., 2001, PHABSIM for Windows-Users' manual and exercises: U.S. Geological Survey Open-File Report 2001-340, 288 p., accessed November 18, 2008, at $h t t p: / / w w w . f o r t . u s g s . g o v / P r o d u c t s / P u b l i c a t i o n s / p u b$ abstract.asp? PubId $=15000$.

Wolock, D.M., 1997, STATSGO soil characteristics for the conterminous United States: U.S. Geological Survey OpenFile Report 97-656, accessed March 1, 2011, at http://water. usgs.gov/GIS/metadata/usgswrd/XML/muid.xml. 

Tables 2-13 
Table 2A. Station characteristics for gaging stations in the contributing watersheds of the Cache and White River National Wildlife Refuges (NWRs) and vicinity, Arkansas, Missouri, and Oklahoma.

[Major drainage boundaries and locations of U.S. Geological Survey (USGS) gaging stations shown in figure 1; dms, latitude and longitude coordinates in degrees, minutes, and seconds; $\mathrm{mi}^{2}$, square mile; gage location in relation to the refuge property: us, upstream; usds, upstream and downstream (on refuge property); ds, downstream; adj, on an adjacent hydrologically connected river or stream; gage location referenced to: c, Cache River NWR; w, White River NWR; cw, Cache and White River NWRs]

\begin{tabular}{|c|c|c|c|c|c|c|c|}
\hline $\begin{array}{l}\text { USGS } \\
\text { station } \\
\text { number }\end{array}$ & Station name & $\begin{array}{c}\text { County } \\
\text { and } \\
\text { State }\end{array}$ & $\begin{array}{l}\text { Latitude and } \\
\text { longitude } \\
\text { (dms) }\end{array}$ & $\begin{array}{l}\text { Hydrologic } \\
\text { unit }^{b}\end{array}$ & $\begin{array}{c}\text { Drainage } \\
\text { areac }^{c} \\
\left(\mathrm{mi}^{2}\right)\end{array}$ & $\begin{array}{l}\text { Datum } \\
\text { of gage }^{d} \\
\text { (ft) }\end{array}$ & $\begin{array}{c}\text { Gage } \\
\text { location }\end{array}$ \\
\hline \multicolumn{8}{|c|}{ Upper White (1101) } \\
\hline 07074500 & White River at Newport, AR & Jackson, AR & $353618 \mathrm{~N}, 0911719 \mathrm{~W}$ & 11010013 & 19,900 & 194.09 & us-cw \\
\hline \multicolumn{8}{|c|}{ Lower Mississippi-St Francis (0802) } \\
\hline 07077000 & White River at DeValls Bluff, AR & Prairie, AR & $344725 \mathrm{~N}, 0912645 \mathrm{~W}$ & 08020301 & 23,400 & 152.93 & $\begin{array}{l}\text { usds-c } \\
\text { us-w }\end{array}$ \\
\hline 07077380 & Cache River at Egypt, AR & Craighead, AR & $355128 \mathrm{~N}, 0905600 \mathrm{~W}$ & 08020302 & 701 & 222.99 & us-cw \\
\hline 07077500 & Cache River at Patterson, AR & Woodruff, AR & $351611 N, 0911411 \mathrm{~W}$ & 08020302 & 1,040 & 182.96 & $\begin{array}{l}\text { usds-c } \\
\text { us-w }\end{array}$ \\
\hline 07077800 & White River at Clarendon, AR & Monroe, AR & $344108 \mathrm{~N}, 0911855 \mathrm{~W}$ & 08020303 & 25,555 & 139.91 & $\begin{array}{l}\text { ds-c } \\
\text { us-w }\end{array}$ \\
\hline $07077820^{\mathrm{e}}$ & White River at St Charles, AR & Arkansas, AR & $342242 \mathrm{~N}, 0910736 \mathrm{~W}$ & 08020303 & 25,732 & 129.95 & $\begin{array}{l}\text { ds-c } \\
\text { usds-w }\end{array}$ \\
\hline $07077950^{\mathrm{e}}$ & Big Creek at Poplar Grove, AR & Phillips, AR & $343320 \mathrm{~N}, 0905044 \mathrm{~W}$ & 08020304 & 448 & 143.00 & $\begin{array}{l}\text { adj-c } \\
\text { us-w }\end{array}$ \\
\hline $07077952^{\mathrm{e}}$ & Big Creek near Poplar Grove, AR & Phillips, AR & $343017 \mathrm{~N}, 0905059 \mathrm{~W}$ & 08020304 & 459 & 143.00 & $\begin{array}{l}\text { adj-c } \\
\text { us-w }\end{array}$ \\
\hline $07078000^{\mathrm{e}}$ & LaGrue Bayou near Stuttgart, AR & Arkansas, AR & $343155 \mathrm{~N}, 0912120 \mathrm{~W}$ & 08020402 & 175 & 175.14 & $\begin{array}{l}\text { adj-c } \\
\text { us-w }\end{array}$ \\
\hline 07263500 & $\begin{array}{l}\text { Arkansas River at Little Rock, } \\
\text { AR }\end{array}$ & Pulaski, AR & $344500 \mathrm{~N}, 0921625 \mathrm{~W}$ & 11110207 & $\begin{array}{c}158,090 \\
(135,849)\end{array}$ & 223.61 & $\begin{array}{l}\text { adj-c } \\
\text { us-w }\end{array}$ \\
\hline \multicolumn{8}{|c|}{ Lower Mississippi-Yazoo (0803) } \\
\hline 07265450 & $\begin{array}{l}\text { Mississippi River near Arkansas } \\
\text { City, AR }\end{array}$ & Desha, AR & $333327 \mathrm{~N}, 0911415 \mathrm{~W}$ & 08030100 & $1,130,600$ & 96.66 & adj-cw \\
\hline
\end{tabular}

${ }^{a}$ Latitude and longitude coordinates in normal font are referenced to the NAD 27, those in italicized font are referenced to NAD 83.

${ }^{\mathrm{b}}$ The 8-digit hydrologic units were developed by the USGS as a standardized set of hydrologic boundaries and numerical codes for the river-basin units of the United States (Seaber and others, 1994). The 8-digit hydrologic unit code encompasses four levels of subdivision: region (2-digit), subregion (4-digit), accounting unit (6-digit), and cataloging unit (8-digit).

${ }^{c}$ Drainage area in parentheses is shown when the contributing drainage area is less than the actual drainage area. Drainage areas in italicized font are from records of the U.S. Army Corps of Engineers.

${ }^{\mathrm{d}}$ Datum-of-gage values in normal font are from records of the USGS, those in italicized font are from records of the U.S. Army Corps of Engineers. All datum-of-gage values are referenced to NGVD 29.

${ }^{\mathrm{e}}$ Inactive station. 
Table 2B. Hydrologic data periods of record for gaging stations in the contributing watersheds of the Cache and White River National Wildlife Refuges and vicinity, Arkansas, Missouri, and Oklahoma.

[Major drainage boundaries and locations of U.S. Geological Survey (USGS) gaging stations shown in figure 1; USGS hydrologic subregions (and subregion codes) listed as subheadings and also shown in figure 1; water year, October 1, preceding calendar year, through September 30, current calendar year; calendar year, January 1 through December 31]

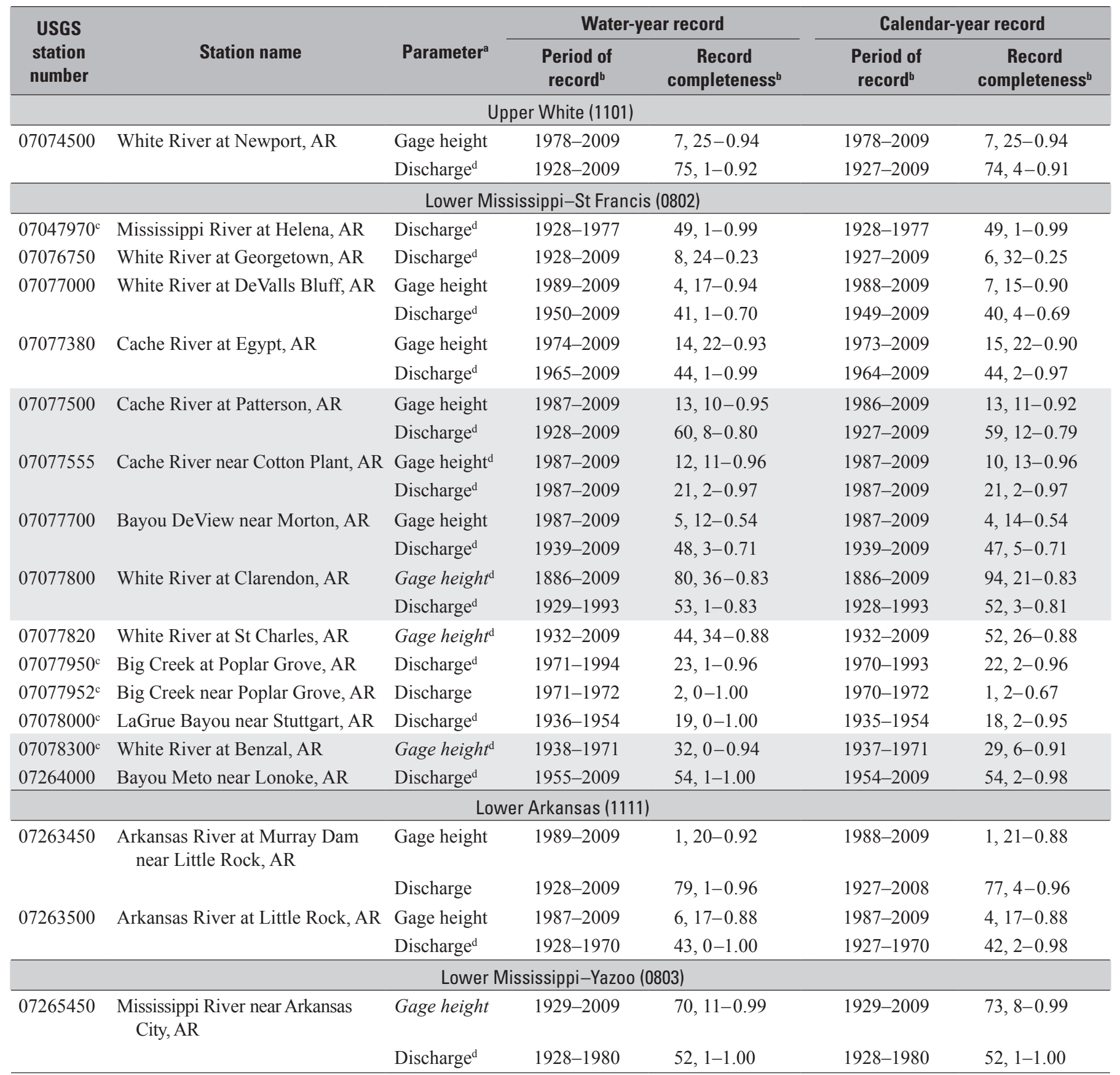

a Parameter designations in normal font indicate data from records of the USGS, designations in italicized font indicate data from records of the U.S. Army Corps of Engineers.

${ }^{b}$ Period shown is for indicated type of year and includes gaps if data collection was discontinuous. Record completeness: number of complete water or calendar years, number of partial-record water or calendar years-fraction of total record length with mean-daily values. The fraction-of-total-record-length calculation is based on complete beginning and ending water or calendar years as well as complete intervening years. Therefore, the fraction-of-total-recordlength numbers may be different for water years when compared to calendar years.

${ }^{\mathrm{c}}$ Inactive station.

${ }^{\mathrm{d}}$ Indicators of Hydrologic Alteration (IHA) analysis was performed for these parameters. Periods of record for IHA analyses shown in figure 4 (gage height) and figure 5 (discharge). 
Table 3. Annotated list of GIS feature classes, tables, and raster datasets in the geodatabase catalogue for the Cache and White River National Wildlife Refuges and contributing watersheds and vicinity, Arkansas, Missouri, and Oklahoma.

[TIGER, Topologically Integrated Geographic Encoding and Referencing; NWR, National Wildlife Refuge; NOAA, National Oceanographic and Atmospheric Administration; USEPA, U.S. Environmental Protection Agency; NHD, National Hydrography Dataset; USGS, U.S. Geological Survey; USACOE, U.S. Army Corps of Engineers; NLCD, National Land Cover Database; STATSGO, State Soil Geographic [Database]; na, not applicable]

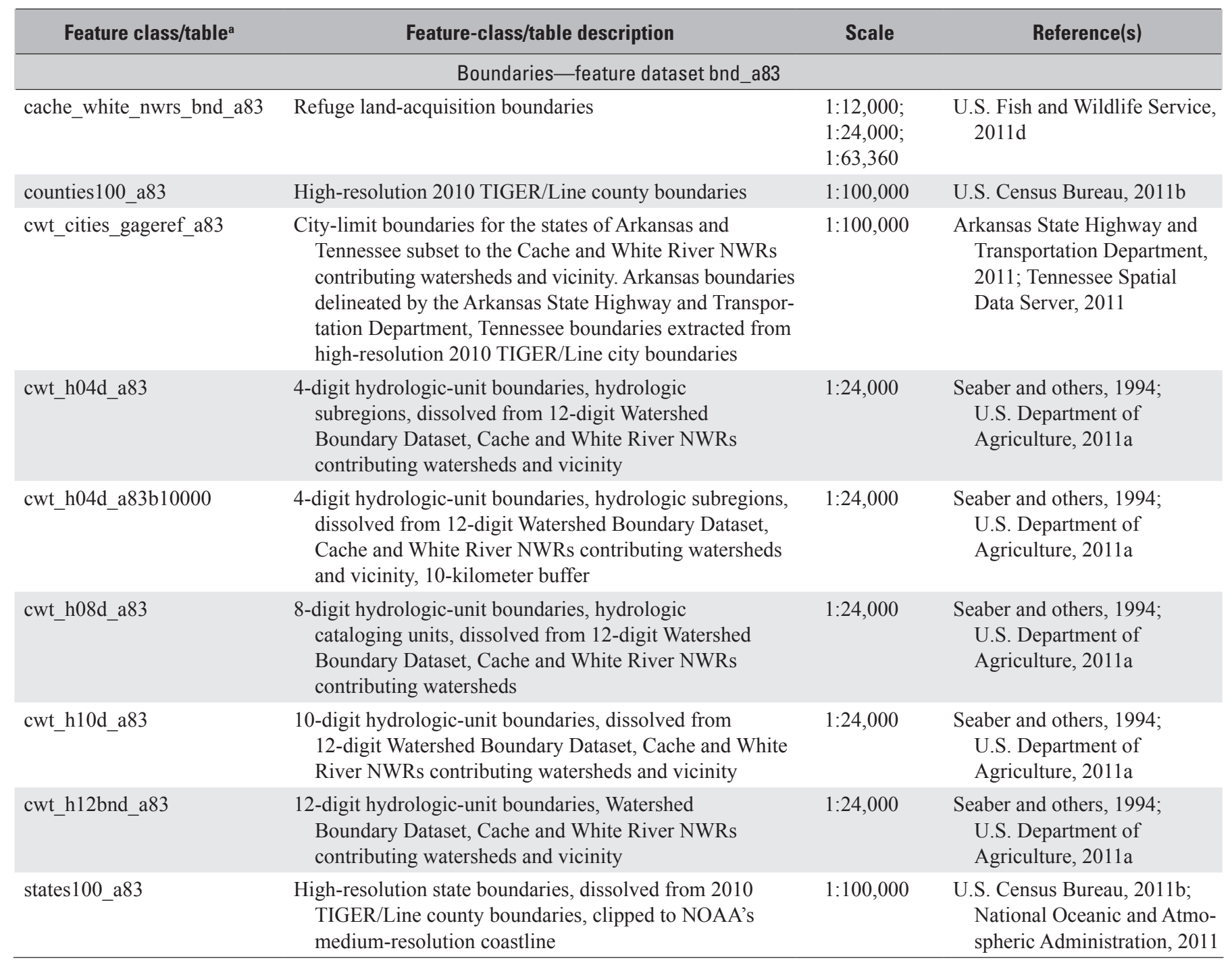


Table 3. Annotated list of GIS feature classes, tables, and raster datasets in the geodatabase catalogue for the Cache and White River National Wildlife Refuges and contributing watersheds and vicinity, Arkansas, Missouri, and Oklahoma.-Continued

[TIGER, Topologically Integrated Geographic Encoding and Referencing; NWR, National Wildlife Refuge; NOAA, National Oceanographic and Atmospheric Administration; USEPA, U.S. Environmental Protection Agency; NHD, National Hydrography Dataset; USGS, U.S. Geological Survey; USACOE, U.S. Army Corps of Engineers; NLCD, National Land Cover Database; STATSGO, State Soil Geographic [Database]; na, not applicable]

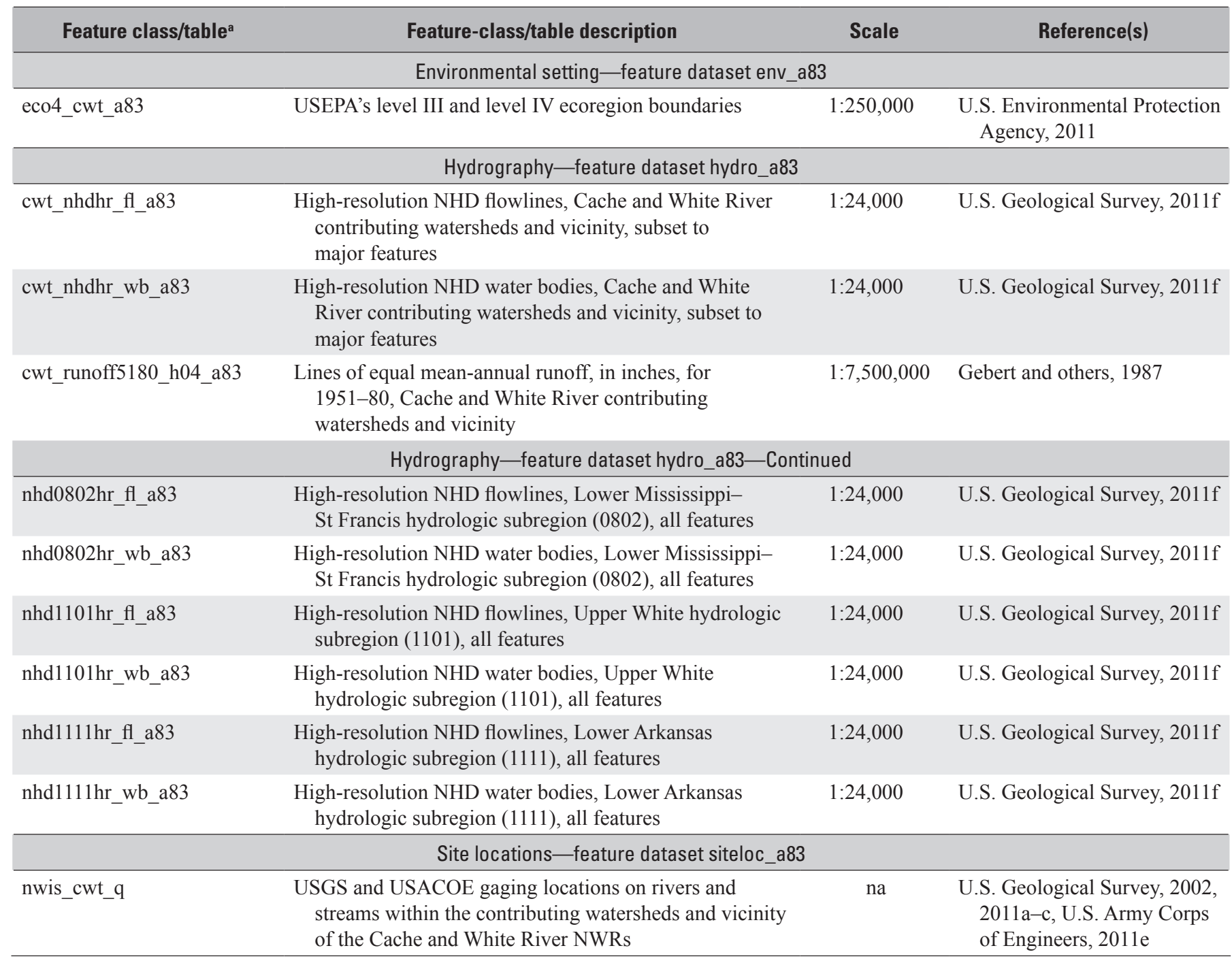


Table 3. Annotated list of GIS feature classes, tables, and raster datasets in the geodatabase catalogue for the Cache and White River National Wildlife Refuges and contributing watersheds and vicinity, Arkansas, Missouri, and Oklahoma.-Continued

[TIGER, Topologically Integrated Geographic Encoding and Referencing; NWR, National Wildlife Refuge; NOAA, National Oceanographic and Atmospheric Administration; USEPA, U.S. Environmental Protection Agency; NHD, National Hydrography Dataset; USGS, U.S. Geological Survey; USACOE, U.S. Army Corps of Engineers; NLCD, National Land Cover Database; STATSGO, State Soil Geographic [Database]; na, not applicable]

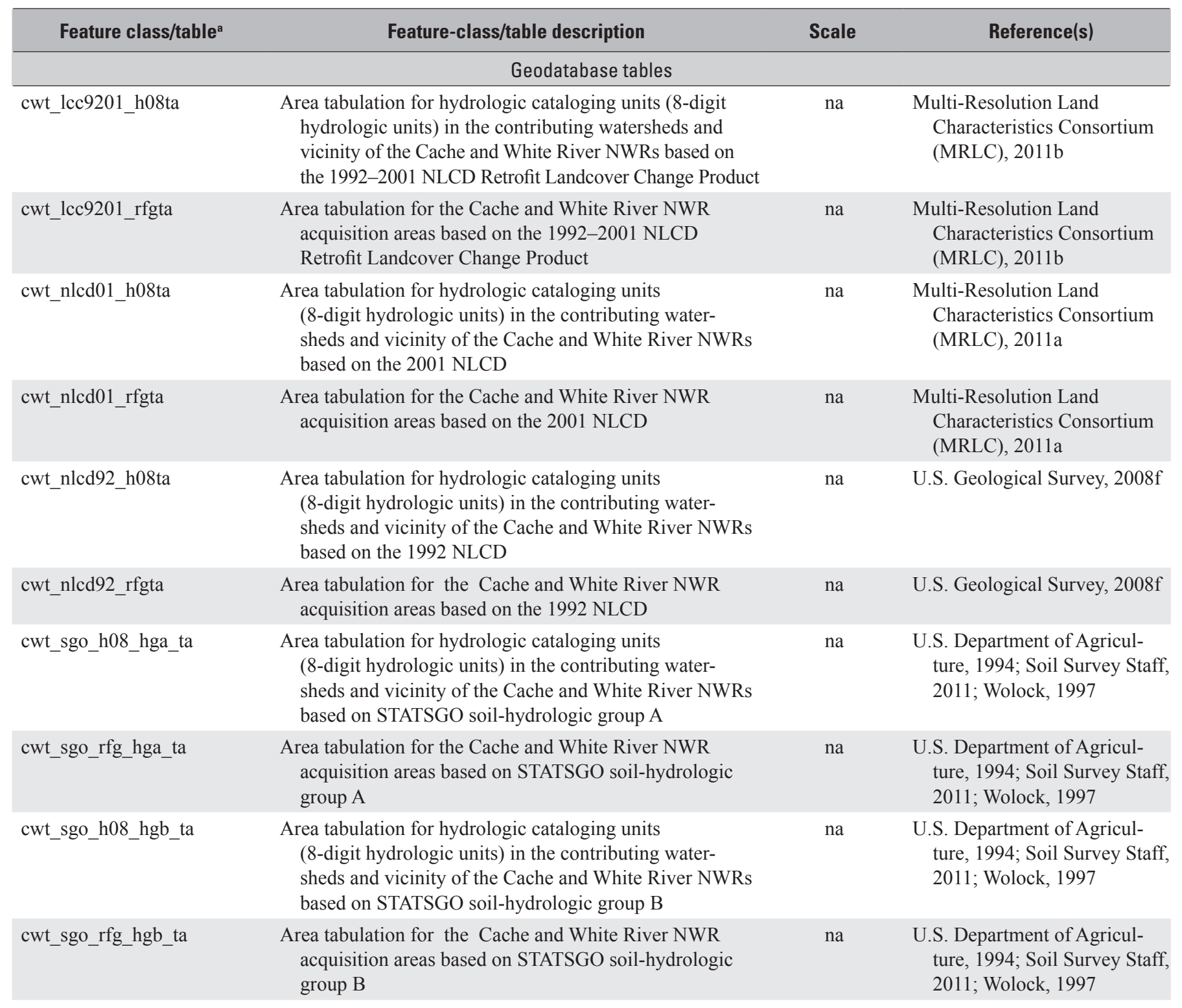


Table 3. Annotated list of GIS feature classes, tables, and raster datasets in the geodatabase catalogue for the Cache and White River National Wildlife Refuges and contributing watersheds and vicinity, Arkansas, Missouri, and Oklahoma.-Continued

[TIGER, Topologically Integrated Geographic Encoding and Referencing; NWR, National Wildlife Refuge; NOAA, National Oceanographic and Atmospheric Administration; USEPA, U.S. Environmental Protection Agency; NHD, National Hydrography Dataset; USGS, U.S. Geological Survey; USACOE, U.S. Army Corps of Engineers; NLCD, National Land Cover Database; STATSGO, State Soil Geographic [Database]; na, not applicable]

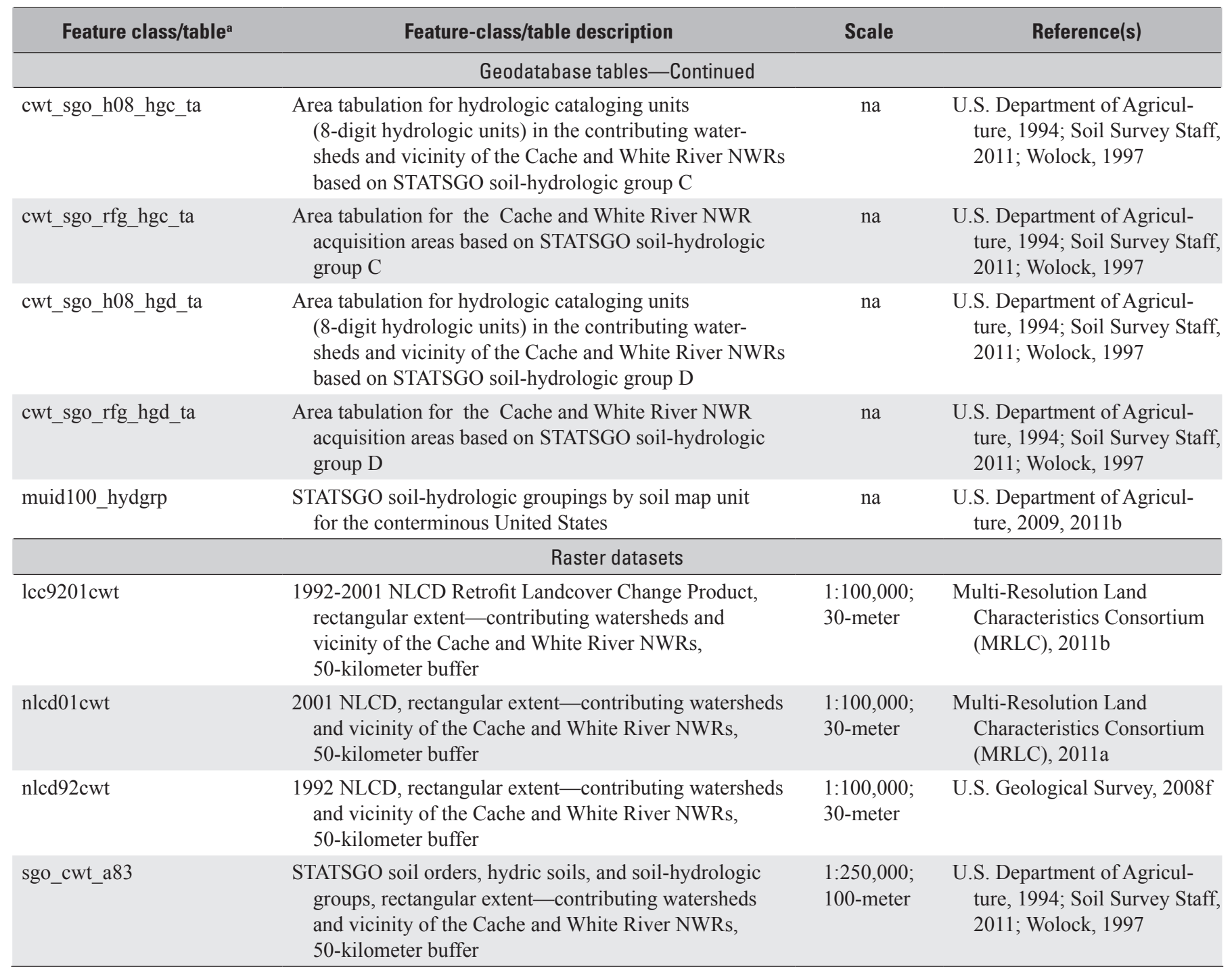

${ }^{a}$ All feature classes and raster datasets projected to USA contiguous Albers equal-area conic projection, central meridian — 96 degrees west, linear unit - meter, horizontal datum_-D_North_American_1983; vector data are stored in ESRI ArcGIS ${ }^{\circledR}$ file geodatabase feature datasets and feature classes (ESRI, 2008); raster data are stored in ESRI ArcINFO ${ }^{\circledR}$ GRID format (ESRI, 2011b); tabular data are stored in ESRI ArcGIS® geodatabase tables (ESRI, 2008). 
Table 4A. Database files, tables/worksheets, and table/worksheet descriptions for the hydrologic and landscape database for the Cache and White River National Wildlife Refuges contributing watersheds and vicinity, Arkansas, Missouri, and Oklahoma.

[NWR, National Wildlife Refuge; gmn, mean-daily gage height, in feet; qmn, mean-daily discharge, in cubic feet per second; calendar year, January 1 through December 31; water year, October 1, preceding calendar year, through September 30, current calendar year; calendar decade, 10-year period beginning on January 1 of year zero and ending on December 31 of year nine; IHA, Indicators of Hydrologic Alteration; EFC, environmental-flow component; USGS, U.S. Geological Survey; USEPA, U.S. Environmental Protection Agency; NLCD, National Land Cover Database; NLCD-LCCR, National Land Cover Database-Land Cover Change Retrofit product; STATSGO, State Soil Geographic [Database]; HSG, hydrologic soil group]

\begin{tabular}{ccc}
\hline File name $^{\mathrm{a}}$ & Table/worksheet name $^{\mathrm{a}}$ & Table/worksheet description $^{\mathrm{a}}$ \\
\hline Raw data $^{\mathrm{b}}$ & \\
\hline
\end{tabular}

cwt tabular hydrostats raw.accdb; cwt001 cwt tabular hydrostats raw.xlsx

Raw data - mean-daily values for gage height and discharge; sum-daily values for precipitation, for gaging stations in the contributing watersheds of the Cache and White River NWRs

Descriptive statistics, spread measures, and ratio measures ${ }^{b}$

\begin{tabular}{|c|c|c|}
\hline $\begin{array}{l}\text { cwt_tabular_hydrostats.accdb; } \\
\text { cwt_tabular_hydrostats_gmn.xlsx; } \\
\text { cwt_tabular_hydrostats_qmn.xlsx }\end{array}$ & cwt $[g m n, q m n] 01$ & Mean-daily gage height $(g m n)$, discharge ( $q m n)$, daily values \\
\hline $\begin{array}{l}\text { cwt_tabular_hydrostats.accdb; } \\
\text { cwt_tabular_hydrostats_gmn.xlsx; } \\
\text { cwt_tabular_hydrostats_qmn.xlsx }\end{array}$ & cwt $[g m n, q m n]$ cy02 & $\begin{array}{l}\text { Calendar-year statistics for gage height }(g m n) \text { and } \\
\text { discharge }(q m n)\end{array}$ \\
\hline $\begin{array}{l}\text { cwt_tabular_hydrostats.accdb; } \\
\text { cwt_tabular_hydrostats_gmn.xlsx; } \\
\text { cwt_tabular_hydrostats_qmn.xlsx }\end{array}$ & $\operatorname{cwt}[g m n, q m n] \mathrm{cd} 02$ & $\begin{array}{l}\text { Calendar-decade statistics for gage height }(g m n) \text { and } \\
\text { discharge }(q m n)\end{array}$ \\
\hline $\begin{array}{l}\text { cwt_tabular_hydrostats.accdb; } \\
\text { cwt_tabular_hydrostats_gmn.xlsx; } \\
\text { cwt_tabular_hydrostats_qmn.xlsx }\end{array}$ & cwt $[g m n, q m n]$ cym02 & $\begin{array}{l}\text { Calendar-year-month statistics for gage height }(g m n) \\
\text { and discharge }(q m n)\end{array}$ \\
\hline $\begin{array}{l}\text { cwt_tabular_hydrostats.accdb; } \\
\text { cwt_tabular_hydrostats_gmn.xlsx; } \\
\text { cwt_tabular_hydrostats_qmn.xlsx }\end{array}$ & $\mathrm{cwt}[g m n, q m n] \mathrm{wy} 02$ & $\begin{array}{l}\text { Water-year statistics for gage height }(g m n) \text { and } \\
\text { discharge }(q m n)\end{array}$ \\
\hline $\begin{array}{l}\text { cwt_tabular_hydrostats.accdb; } \\
\text { cwt_tabular_hydrostats_gmn.xlsx; } \\
\text { cwt_tabular_hydrostats_qmn.xlsx }\end{array}$ & $\mathrm{cwt}[g m n, q m n] \mathrm{mom} 02$ & $\begin{array}{l}\text { Period-of-record monthly statistics metrics, based on annual } \\
\text { monthly means of mean-daily values, for gage height ( } g m n) \\
\text { and discharge }(q m n) \text {, complete calendar years }\end{array}$ \\
\hline $\begin{array}{l}\text { cwt_tabular_hydrostats.accdb; } \\
\text { cwt_tabular_hydrostats_gmn.xlsx; } \\
\text { cwt_tabular_hydrostats_qmn.xlsx }\end{array}$ & $\mathrm{cwt}[g m n, q m n] \mathrm{jc} 02$ & $\begin{array}{l}\text { Period-of-record calendar-year-julian-day statistics, based on } \\
\text { mean-daily values, for gage height }(g m n) \text { and discharge } \\
(q m n) \text {, complete calendar years }\end{array}$ \\
\hline $\begin{array}{l}\text { cwt_tabular_hydrostats.accdb; } \\
\text { cwt_tabular_hydrostats_gmn.xlsx; } \\
\text { cwt_tabular_hydrostats_qmn.xlsx }\end{array}$ & $\mathrm{cwt}[g m n, q m n] \mathrm{jw} 02$ & $\begin{array}{l}\text { Period-of-record water-year-julian-day statistics, based on } \\
\text { mean-daily values, for gage height }(\mathrm{gmn}) \text { and discharge } \\
(q m n), \text { complete calendar years }\end{array}$ \\
\hline
\end{tabular}
Hydrologic metrics ${ }^{b}$

cwt tabular hydmetrics.accdb; cwt_tabular_hydmetrics.xlsx

cwt_tabular_hydmetrics.accdb; cwt_tabular_hydmetrics.xlsx

cwt_tabular_hydmetrics.accdb; cwt_tabular_hydmetrics.xlsx hydmetrics_cwt_wyear_ [gmn,qmn]_por

hydmetrics_cwt_cyear_ $[g m n, q m n]$ ap
Period-of-record hydrologic metrics, based on mean-daily values, for gage height ( $g m n)$ and discharge ( $q m n)$, complete calendar years; departure metrics indexed to the period of record for complete calendar years

Period-of-record hydrologic metrics, based on mean-daily values, for gage height ( $\mathrm{gmn}$ ) and discharge ( $q m n$ ), complete water years; departure metrics indexed to the period of record for complete water years

Calendar-year hydrologic metrics, based on mean-daily values, for gage height ( $g m n$ ) and discharge ( $q m n$ ), complete and partial calendar years; departure metrics indexed to each calendar year 
Table 4A. Database files, tables/worksheets, and table/worksheet descriptions for the hydrologic and landscape database for the Cache and White River National Wildlife Refuges contributing watersheds and vicinity, Arkansas, Missouri, and Oklahoma.-Continued

[NWR, National Wildlife Refuge; gmn, mean-daily gage height, in feet; qmn, mean-daily discharge, in cubic feet per second; calendar year, January 1 through December 31; water year, October 1, preceding calendar year, through September 30, current calendar year; calendar decade, 10-year period beginning on January 1 of year zero and ending on December 31 of year nine; IHA, Indicators of Hydrologic Alteration; EFC, environmental-flow component; USGS, U.S. Geological Survey; USEPA, U.S. Environmental Protection Agency; NLCD, National Land Cover Database; NLCD-LCCR, National Land Cover Database-Land Cover Change Retrofit product; STATSGO, State Soil Geographic [Database]; HSG, hydrologic soil group]

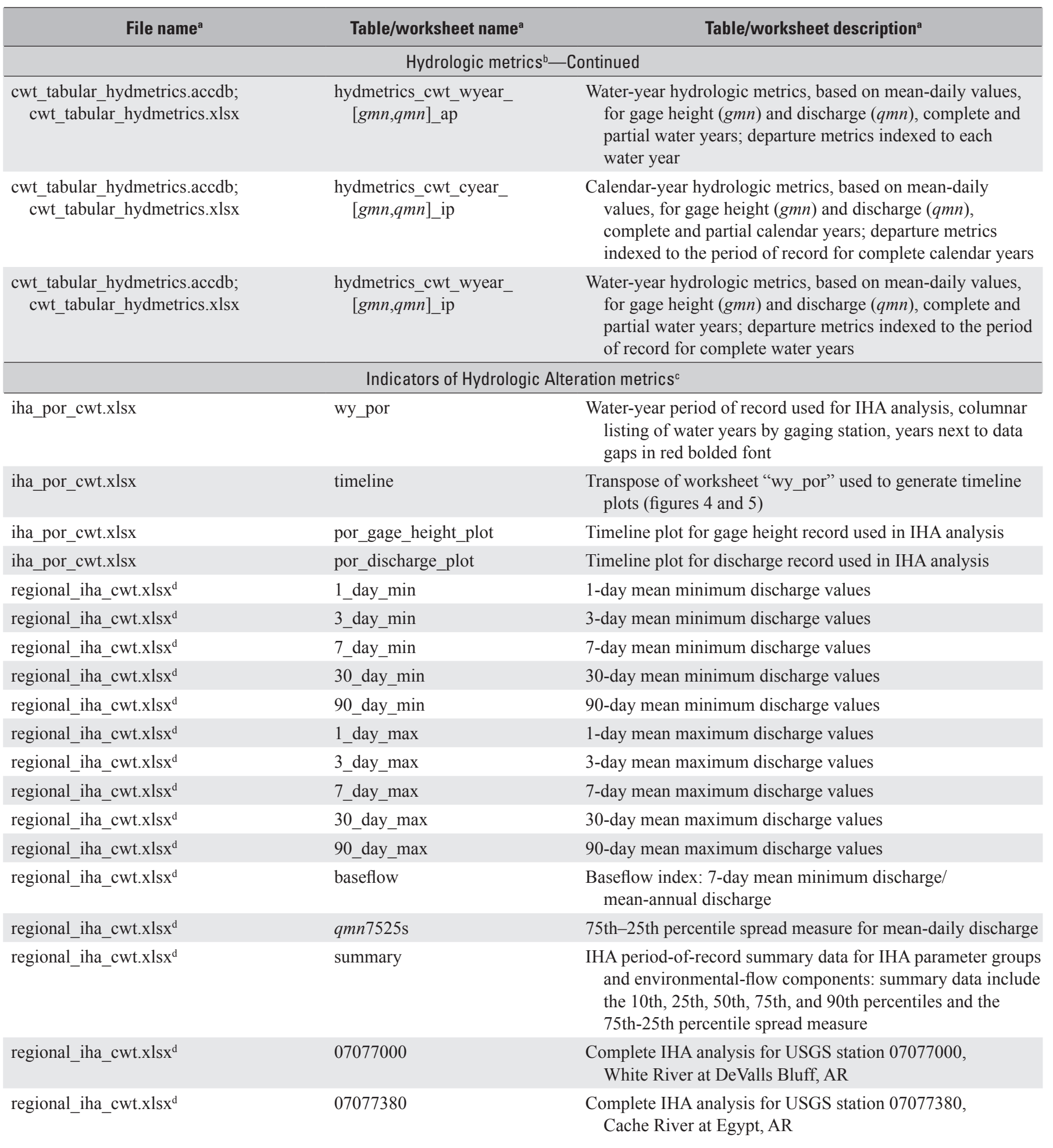


Table 4A. Database files, tables/worksheets, and table/worksheet descriptions for the hydrologic and landscape database for the Cache and White River National Wildlife Refuges contributing watersheds and vicinity, Arkansas, Missouri, and Oklahoma.-Continued

[NWR, National Wildlife Refuge; gmn, mean-daily gage height, in feet; qmn, mean-daily discharge, in cubic feet per second; calendar year, January 1 through December 31; water year, October 1, preceding calendar year, through September 30, current calendar year; calendar decade, 10-year period beginning on January 1 of year zero and ending on December 31 of year nine; IHA, Indicators of Hydrologic Alteration; EFC, environmental-flow component; USGS, U.S. Geological Survey; USEPA, U.S. Environmental Protection Agency; NLCD, National Land Cover Database; NLCD-LCCR, National Land Cover Database-Land Cover Change Retrofit product; STATSGO, State Soil Geographic [Database]; HSG, hydrologic soil group]

\begin{tabular}{|c|c|c|}
\hline File name ${ }^{a}$ & Table/worksheet name ${ }^{a}$ & Table/worksheet description ${ }^{a}$ \\
\hline \multicolumn{3}{|c|}{ Indicators of Hydrologic Alteration metrics ${ }^{c}$ - Continued } \\
\hline regional_iha_cwt.xlsx ${ }^{\mathrm{d}}$ & 07077500 & $\begin{array}{l}\text { Complete IHA analysis for USGS station } 07077500 \text {, } \\
\text { Cache River at Patterson, AR }\end{array}$ \\
\hline regional_iha_cwt.xlsx ${ }^{\mathrm{d}}$ & 07077555 & $\begin{array}{l}\text { Complete IHA analysis for USGS station } 07077555 \text {, } \\
\text { Cache River near Cotton Plant, AR }\end{array}$ \\
\hline regional_iha_cwt.xlsx ${ }^{d}$ & 07077800 & $\begin{array}{l}\text { Complete IHA analysis for USGS station } 07077800 \text {, } \\
\text { White River at Clarendon, AR }\end{array}$ \\
\hline sSSSSSSSS_iha_[gmn,qmn].xlsx & ann & $\begin{array}{l}\text { Water-year annual values for all IHA parameter groups and } \\
\text { EFC groups, gage height (gmn), discharge (qmn), gaging } \\
\text { station SSSSSSSS (parameter definitions given in table 5) }\end{array}$ \\
\hline sSSSSSSSS_iha_[gmn,qmn].xlsx & lsq & $\begin{array}{l}\text { Linear-regression models for IHA parameter groups and EFC } \\
\text { groups with water year, gage height (gmn), discharge (qmn), } \\
\text { gaging station } S S S S S S S^{e}\end{array}$ \\
\hline sSSSSSSSS_iha_[gmn,qmn].xlsx & pet & $\begin{array}{l}\text { IHA period-of-record summary data for IHA parameter groups } \\
\text { and EFC groups: summary data include the 10th, 25th, } \\
\text { 50th, 75th, and 90th percentiles and the 75th-25th percen- } \\
\text { tile spread measure, gage height (gmn), discharge (qmn), } \\
\text { gaging station SSSSSSSS }\end{array}$ \\
\hline sSSSSSSSS_iha_[gmn,qmn].xlsx & daily_efcs & $\begin{array}{l}\text { Mean-daily values coded with IHA EFC groups, period of } \\
\text { record, gage height }(g m n) \text {, discharge }(q m n) \text {, gaging station } \\
\text { SSSSSSSS }\end{array}$ \\
\hline cwt_nlcd.xlsx & cwt_nlcd01_h0408rfg_pct & $\begin{array}{l}\text { Land-cover percentages for hydrologic subregions and } \\
\text { cataloging units (contributing-watershed area and vicinity } \\
\text { for the Cache and White River NWRs) and refuge } \\
\text { acquisition areas based on } 2001 \text { NLCD level } 2 \text { categories } \\
\text { (Multi-Resolution Land Characteristics Consortium } \\
\text { [MRLC], 2011a) }\end{array}$ \\
\hline
\end{tabular}


Table 4A. Database files, tables/worksheets, and table/worksheet descriptions for the hydrologic and landscape database for the Cache and White River National Wildlife Refuges contributing watersheds and vicinity, Arkansas, Missouri, and Oklahoma.-Continued

[NWR, National Wildlife Refuge; gmn, mean-daily gage height, in feet; qmn, mean-daily discharge, in cubic feet per second; calendar year, January 1 through December 31; water year, October 1, preceding calendar year, through September 30, current calendar year; calendar decade, 10-year period beginning on January 1 of year zero and ending on December 31 of year nine; IHA, Indicators of Hydrologic Alteration; EFC, environmental-flow component; USGS, U.S. Geological Survey; USEPA, U.S. Environmental Protection Agency; NLCD, National Land Cover Database; NLCD-LCCR, National Land Cover Database-Land Cover Change Retrofit product; STATSGO, State Soil Geographic [Database]; HSG, hydrologic soil group]

\begin{tabular}{ccc}
\hline File name $^{\mathrm{a}}$ & Table/worksheet name $^{\mathrm{a}}$ & Table/worksheet description $^{\mathrm{a}}$ \\
\hline \multicolumn{2}{c}{ Geospatial data summaries_Continued } \\
\hline
\end{tabular}

cwt_nlcd.xlsx cwt_lcc9201_h0408rfg_pct Land-cover-change percentages for hydrologic subregions
and cataloging units (contributing-watershed area and vicinity for the Cache and White River NWRs) and refuge acquisition areas based on 1992-2001 NLCD-LCCR Anderson Level 1 categories (Multi-Resolution Land Characteristics Consortium (MRLC), 2011b; Fry and others, 2008; Anderson and others, 1976)

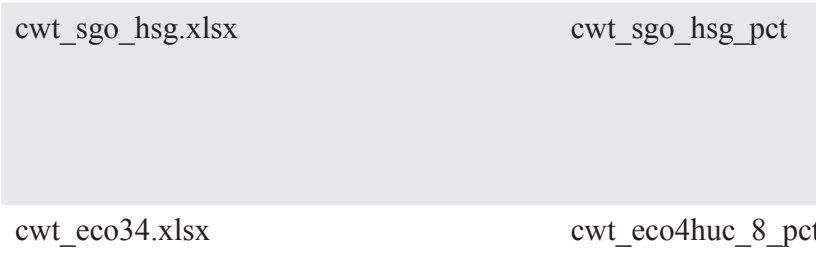

cwt eco34.xlsx

cwt_eco3huc_8_pct

cwt_eco34.xlsx

cwt_eco4huc_4_pct

STATSGO database HSGs A through D percentages for hydrologic subregions and cataloging units (contributingwatershed area and vicinity for the Cache and White River NWRs) and refuge acquisition areas (U.S. Department of Agriculture, 1994, 2009, 2011b; Wolock, 1997)

USEPA Level IV ecoregion percentages for hydrologic subregions (contributing-watershed area and vicinity for the Cache and White River NWRs) (U.S. Environmental Protection Agency, 2011)

USEPA Level III ecoregion percentages for hydrologic subregions (contributing-watershed area and vicinity for the Cache and White River NWRs) (U.S. Environmental Protection Agency, 2011)

USEPA Level IV ecoregion percentages for hydrologic cataloging units (contributing-watershed area and vicinity for the Cache and White River NWRs) (U.S. Environmental Protection Agency, 2011)

USEPA Level III ecoregion percentages for hydrologic cataloging units (contributing-watershed area and vicinity for the Cache and White River NWRs) (U.S. Environmental Protection Agency, 2011)

cwt_pop_census.xlsx tblCwtPop01

cwt_pop_census.xlsx pop_pct_chg

U.S. Census Bureau county-level population data, 1930-2010 (U.S. Census Bureau, 2011a)

Descriptive statistics for percent population change, 1930-1970, and 1970-2010

\footnotetext{
${ }^{a}$ Tables refer to Microsoft Access ${ }^{\circledR}$ files, worksheets refer to Microsoft Excel ${ }^{\circledR}$ files.

${ }^{\mathrm{b}}$ Field names, field types, and field definitions listed in table $4 B$; gmn, mean-daily gage height, in feet; qmn, mean-daily discharge, in cubic feet per second.

${ }^{c}$ IHA parameter-groups, EFC groups, EFCs, and parameter definitions listed in table 5 (Richter and others, 1996; The Nature Conservancy, 2007, 2009).

${ }^{\mathrm{d}}$ IHA regional analysis restricted to USGS gaging stations 07077000, 07077380, 07077500, 07077555, 07077700, and 07077800. Gaging-station information presented in tables $2 A$ and $2 B$.
}

${ }^{e}$ IHA analysis of mean-daily gage-height record for USGS gaging stations $07077555,07077800,07077820,07078300$; IHA analysis of mean-daily discharge record for USGS gaging stations 07047970, 07074500, 07076750, 07077000, 07077380, 07077500, 07077555, 07077700, 07077800, 07077950, 07078000, 07263500, 07264000, and 07265450. Gaging-station characteristics, parameters, and periods of record listed in tables $2 A$ and $2 B$. 
Table 4B. Database field names, field types, and field definitions for the hydrologic and landscape database for the Cache and White River National Wildlife Refuges contributing watersheds and vicinity, Arkansas, Missouri, and Oklahoma.

[USGS, U.S. Geological Survey; NAD 83, North American Datum of 1983; NGVD 29, National Geodetic Vertical Datum of 1929; FIPS, Federal Information Processing Standards; NLCD, National Land Cover Database; HSG, hydrologic soil group (U.S. Department of Agriculture, 2009, 2011b); calendar year, January 1 through December 31; water year,October 1, preceding calendar year, through September 30, current calendar year; calendar decade, 10-year period beginning on January 1 of year zero and ending on December 31 of year nine; $\mathrm{ft}^{3} \mathrm{~s}^{-1}$, cubic foot per second; $\mathrm{ft}^{3} \mathrm{~s}^{-1} \mathrm{mi}^{-2}$, cubic foot per second per square mile; $\mathrm{ft}$, foot; in, inch; $\mathrm{mi}^{2}$, square mile; gmn, mean-daily gage height, in ft; qmn, mean-daily discharge, in $\mathrm{ft}^{3} \mathrm{~s}^{-1} ; \mathrm{p} 90,90$ th percentile; $\mathrm{p} 75,75$ th percentile; $\mathrm{p} 50$, 50th percentile (median); p25, 25th percentile; p10, 10th percentile; specified period of analysis: por, period of record; cy, calendar year; wy, water year]

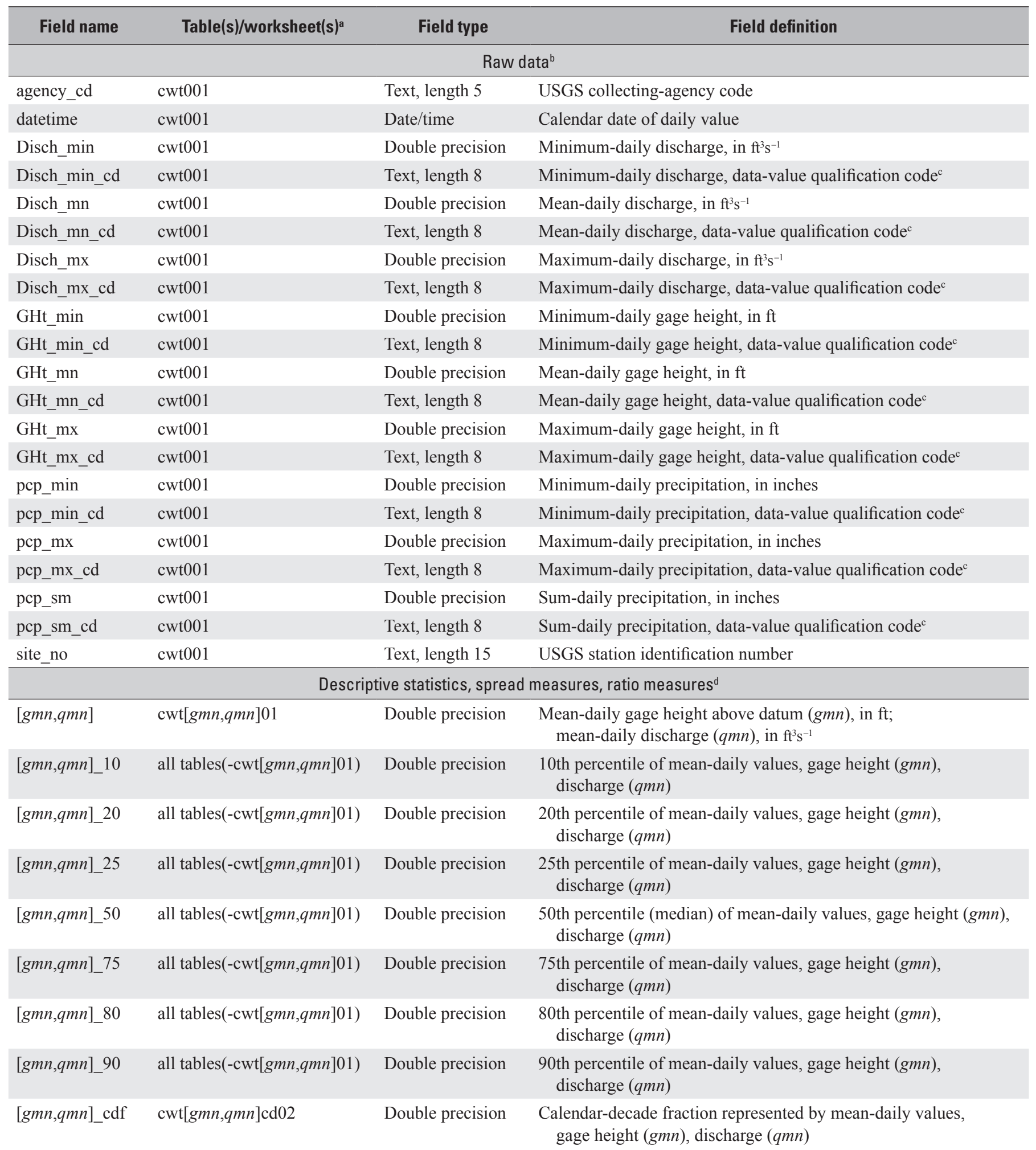


Table 4B. Database field names, field types, and field definitions for the hydrologic and landscape database for the Cache and White River National Wildlife Refuges contributing watersheds and vicinity, Arkansas, Missouri, and Oklahoma.-Continued

[USGS, U.S. Geological Survey; NAD 83, North American Datum of 1983; NGVD 29, National Geodetic Vertical Datum of 1929; FIPS, Federal Information Processing Standards; NLCD, National Land Cover Database; HSG, hydrologic soil group (U.S. Department of Agriculture, 2009, 2011b); calendar year, January 1 through December 31; water year,October 1, preceding calendar year, through September 30, current calendar year; calendar decade, 10-year period beginning on January 1 of year zero and ending on December 31 of year nine; $\mathrm{ft}^{3} \mathrm{~s}^{-1}$, cubic foot per second; $\mathrm{ft}^{3} \mathrm{~s}^{-1} \mathrm{mi}^{-2}$, cubic foot per second per square mile; $\mathrm{ft}$, foot; in, inch; $\mathrm{mi}^{2}$, square mile; gmn, mean-daily gage height, in ft; qmn, mean-daily discharge, in $\mathrm{ft}^{3} \mathrm{~s}^{-1} ; \mathrm{p} 90,90$ th percentile; $\mathrm{p} 75,75$ th percentile; $\mathrm{p} 50$, 50th percentile (median); p25, 25th percentile; p10, 10th percentile; specified period of analysis: por, period of record; cy, calendar year; wy, water year]

\begin{tabular}{|c|c|c|c|}
\hline Field name & Table(s)/worksheet(s) ${ }^{a}$ & Field type & Field definition \\
\hline$[g m n, q m n] \_c m f$ & cwt $[g m n, q m n] \operatorname{cym} 02$ & Double precision & $\begin{array}{l}\text { Calendar-month fraction represented by mean-daily values, gage } \\
\text { height }(g m n) \text {, discharge }(q m n)\end{array}$ \\
\hline$[g m n, q m n] \_c v$ & all tables(-cwt $[g m n, q m n] 01)$ & Double precision & $\begin{array}{l}\text { Coefficient of variation of mean-daily values, gage height }(\mathrm{gmn}) \text {, } \\
\text { discharge }(q m n)\end{array}$ \\
\hline [gmn,qmn]_cyf & $\begin{array}{l}\mathrm{cwt}[\mathrm{gmn}, q m n] \mathrm{cy} 02 ; \\
\mathrm{cwt}[\mathrm{gmn}, q m n] \mathrm{cym} 02\end{array}$ & Double precision & $\begin{array}{l}\text { Calendar-year fraction represented by mean-daily values, gage } \\
\text { height }(g m n) \text {, discharge }(q m n)\end{array}$ \\
\hline$[g m n, q m n] \_m i$ & all tables(-cwt $[g m n, q m n] 01)$ & Double precision & Minimum of mean-daily values, gage height $(\mathrm{gmn})$, discharge $(q m n)$ \\
\hline$[g m n, q m n] \_m n$ & all tables(-cwt $[g m n, q m n] 01)$ & Double precision & Mean of mean-daily values, gage height $(\mathrm{gmn})$, discharge $(\mathrm{qmn})$ \\
\hline$[g m n, q m n] \_n y$ & $\mathrm{cwt}[g m n, q m n] \mathrm{cd} 02$ & Double precision & $\begin{array}{l}\text { Number of calendar years in each calendar decade, including frac- } \\
\text { tional years, represented by mean-daily values, gage height }(g m n) \text {, } \\
\text { discharge }(q m n)\end{array}$ \\
\hline$[g m n, q m n] \_s d$ & all tables(-cwt $[g m n, q m n] 01)$ & Double precision & $\begin{array}{l}\text { Standard deviation of mean-daily values, gage height }(g m n) \text {, } \\
\text { discharge }(q m n)\end{array}$ \\
\hline$[g m n, q m n] \_$va & all tables(-cwt $[g m n, q m n] 01)$ & Double precision & Variance of mean-daily values, gage height $(g m n)$, discharge ( $q m n)$ \\
\hline$[g m n, q m n] \_w y f$ & $\mathrm{cwt}[g m n, q m n] \mathrm{wy} 02$ & Double precision & $\begin{array}{l}\text { Water-year fraction represented by mean-daily values, } \\
\text { gage height }(g m n) \text {, discharge }(q m n)\end{array}$ \\
\hline$[g m n, q m n] 7525 \mathrm{r}$ & all tables(-cwt $[g m n, q m n] 01)$ & Double precision & $\begin{array}{l}\text { 75th-25th percentile ratio measure of mean-daily values, } \\
\text { gage height }(g m n) \text {, discharge }(q m n): \text { p } 75 / \text { p } 25\end{array}$ \\
\hline$[g m n, q m n] 9010 \mathrm{r}$ & all tables(-cwt $[g m n, q m n] 01)$ & Double precision & $\begin{array}{l}\text { 90th-10th percentile ratio measure of mean-daily values, } \\
\text { gage height }(g m n) \text {, discharge }(q m n): \text { p } 90 / \text { p } 10\end{array}$ \\
\hline$[g m n, q m n] 9010 \mathrm{~s}$ & all tables(-cwt $[g m n, q m n] 01)$ & Double precision & $\begin{array}{l}\text { 90th-10th percentile spread measure of mean-daily values, } \\
\text { gage height }(g m n) \text {, discharge }(q m n):(\mathrm{p} 90-\mathrm{p} 10) / \mathrm{p} 50\end{array}$ \\
\hline cnty & $\operatorname{cwt}[g m n, q m n] 01$ & Not applicable & FIPS county code \\
\hline da & all tables & Double precision & Drainage area of gaged watershed, in $\mathrm{mi}^{2}$ \\
\hline date & $\mathrm{cwt}[\mathrm{gmn}, q m n] 01$ & Date/time & Date, $\mathrm{mm} / \mathrm{dd} /$ yyyy format \\
\hline day & cwt $[g m n, q m n] 01$ & Long integer & Calendar day \\
\hline decade & $\begin{array}{l}\operatorname{cwt}[g m n, q m n] 01 \\
\quad \operatorname{cwt}[g m n, q m n] \operatorname{cd} 02\end{array}$ & Long integer & Calendar decade \\
\hline jday_c & $\begin{array}{l}\operatorname{cwt}[g m n, q m n] 01 \\
\quad \operatorname{cwt}[g m n, q m n] \mathrm{jc} 02\end{array}$ & Long integer & Calendar-year Julian day \\
\hline
\end{tabular}


Table 4B. Database field names, field types, and field definitions for the hydrologic and landscape database for the Cache and White River National Wildlife Refuges contributing watersheds and vicinity, Arkansas, Missouri, and Oklahoma.-Continued

[USGS, U.S. Geological Survey; NAD 83, North American Datum of 1983; NGVD 29, National Geodetic Vertical Datum of 1929; FIPS, Federal Information Processing Standards; NLCD, National Land Cover Database; HSG, hydrologic soil group (U.S. Department of Agriculture, 2009, 2011b); calendar year, January 1 through December 31; water year,October 1, preceding calendar year, through September 30, current calendar year; calendar decade, 10-year period beginning on January 1 of year zero and ending on December 31 of year nine; $\mathrm{ft}^{3} \mathrm{~s}^{-1}$, cubic foot per second; $\mathrm{ft}^{3} \mathrm{~s}^{-1} \mathrm{mi}^{-2}$, cubic foot per second per square mile; $\mathrm{ft}$, foot; in, inch; $\mathrm{mi}^{2}$, square mile; gmn, mean-daily gage height, in ft; qmn, mean-daily discharge, in $\mathrm{ft}^{3} \mathrm{~s}^{-1} ; \mathrm{p} 90,90$ th percentile; $\mathrm{p} 75,75$ th percentile; $\mathrm{p} 50$, 50th percentile (median); p25, 25th percentile; p10, 10th percentile; specified period of analysis: por, period of record; cy, calendar year; wy, water year]

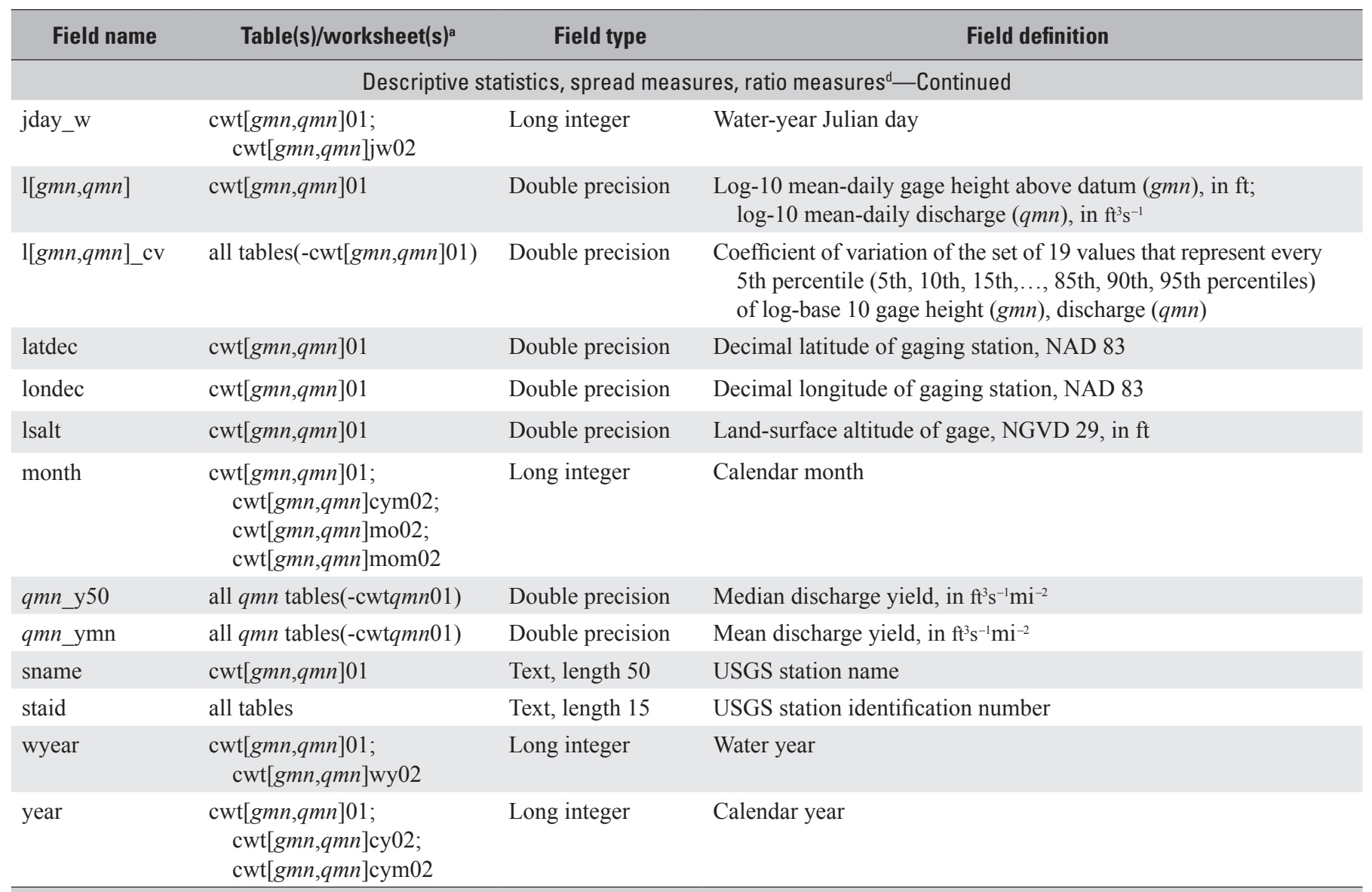

\begin{tabular}{|c|c|c|c|}
\hline \multicolumn{4}{|c|}{ Hydrologic metrics ${ }^{\mathrm{e}}$} \\
\hline$[g m n, q m n] \_\mathrm{cv}$ & all tables & Double precision & $\begin{array}{l}\text { Coefficient of varaiation of mean-daily gage height }(\mathrm{gmn}), \\
\text { discharge }(q m n) \text {, specified period of analysis (por, cy, wy) }\end{array}$ \\
\hline [gmn,qmn]_sk & all tables & Double precision & $\begin{array}{l}\text { Skewness of mean-daily gage height }(g m n) \text {, discharge }(q m n) \text {, } \\
\text { specified period of analysis (por, cy, wy) }\end{array}$ \\
\hline cum_50 & all tables & Double precision & $\begin{array}{l}\text { Sum incremental change in gage height }(\mathrm{gmn}) \text {, discharge }(\mathrm{qmn}) \text {, } \\
\text { absolute value, specified period of analysis (por, cy, wy), } \\
\text { normalized to the median incremental change }\end{array}$ \\
\hline cy_mi & $\begin{array}{l}\text { hydmetrics_cwt_cyear_- } \\
\text { [gmn,qmn]_por }\end{array}$ & Long integer & $\begin{array}{l}\text { Calendar-year begin-year of record, complete calendar years only, } \\
\text { gage height }(g m n) \text {, discharge }(q m n)\end{array}$ \\
\hline
\end{tabular}


Table 4B. Database field names, field types, and field definitions for the hydrologic and landscape database for the Cache and White River National Wildlife Refuges contributing watersheds and vicinity, Arkansas, Missouri, and Oklahoma.-Continued

[USGS, U.S. Geological Survey; NAD 83, North American Datum of 1983; NGVD 29, National Geodetic Vertical Datum of 1929; FIPS, Federal Information Processing Standards; NLCD, National Land Cover Database; HSG, hydrologic soil group (U.S. Department of Agriculture, 2009, 2011b); calendar year, January 1 through December 31; water year,October 1, preceding calendar year, through September 30, current calendar year; calendar decade, 10-year period beginning on January 1 of year zero and ending on December 31 of year nine; $\mathrm{ft}^{3} \mathrm{~s}^{-1}$, cubic foot per second; $\mathrm{ft}^{3} \mathrm{~s}^{-1} \mathrm{mi}^{-2}$, cubic foot per second per square mile; $\mathrm{ft}$, foot; in, inch; $\mathrm{mi}^{2}$, square mile; gmn, mean-daily gage height, in ft; qmn, mean-daily discharge, in $\mathrm{ft}^{3} \mathrm{~s}^{-1} ; \mathrm{p} 90,90$ th percentile; $\mathrm{p} 75,75$ th percentile; $\mathrm{p} 50$, 50th percentile (median); p25, 25th percentile; p10, 10th percentile; specified period of analysis: por, period of record; cy, calendar year; wy, water year]

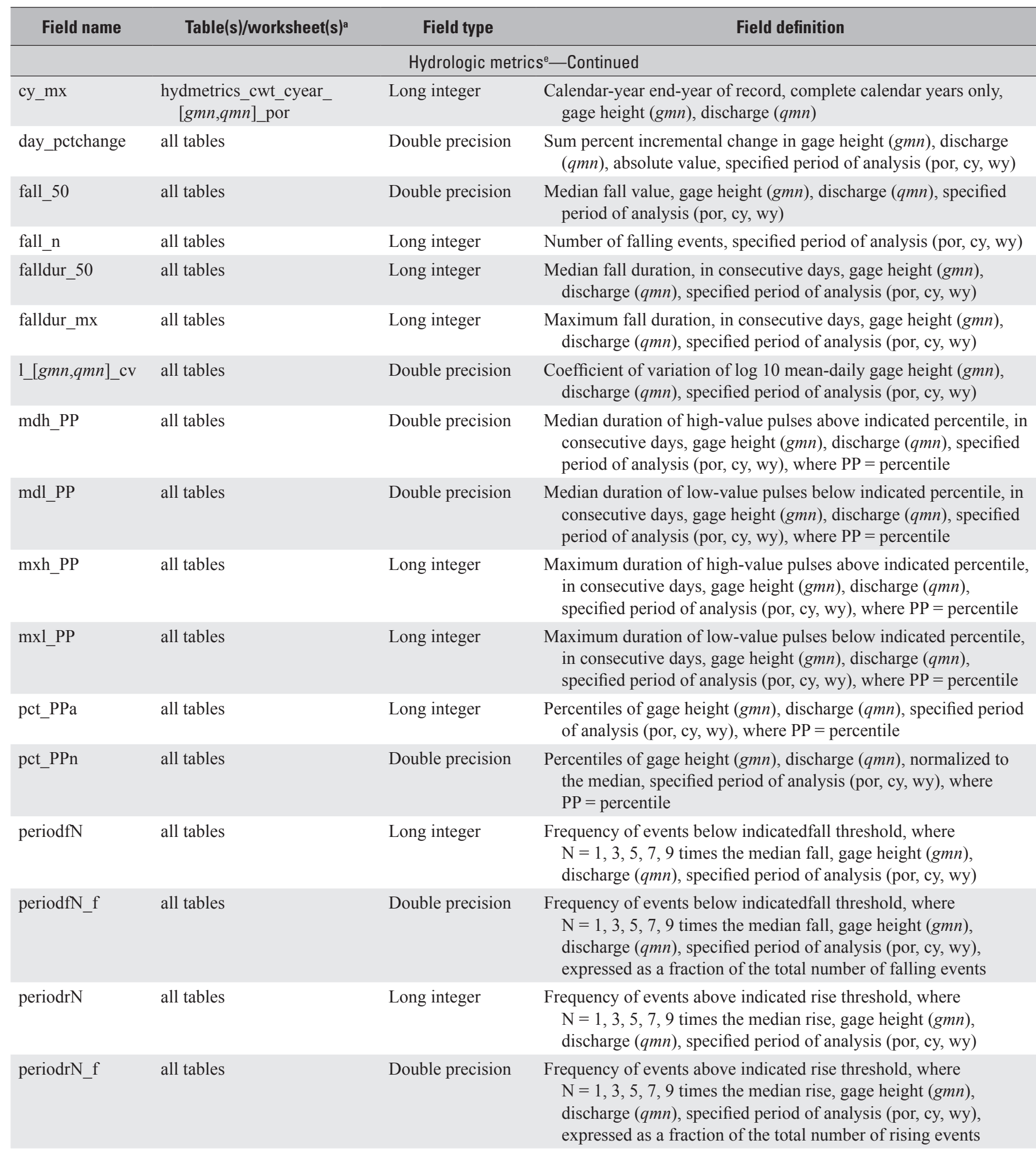


Table 4B. Database field names, field types, and field definitions for the hydrologic and landscape database for the Cache and White River National Wildlife Refuges contributing watersheds and vicinity, Arkansas, Missouri, and Oklahoma.-Continued

[USGS, U.S. Geological Survey; NAD 83, North American Datum of 1983; NGVD 29, National Geodetic Vertical Datum of 1929; FIPS, Federal Information Processing Standards; NLCD, National Land Cover Database; HSG, hydrologic soil group (U.S. Department of Agriculture, 2009, 2011b); calendar year, January 1 through December 31; water year,October 1, preceding calendar year, through September 30, current calendar year; calendar decade, 10-year period beginning on January 1 of year zero and ending on December 31 of year nine; $\mathrm{ft}^{3} \mathrm{~s}^{-1}$, cubic foot per second; $\mathrm{ft}^{3} \mathrm{~s}^{-1} \mathrm{mi}^{-2}$, cubic foot per second per square mile; $\mathrm{ft}$, foot; in, inch; $\mathrm{mi}^{2}$, square mile; gmn, mean-daily gage height, in ft; qmn, mean-daily discharge, in $\mathrm{ft}^{3} \mathrm{~s}^{-1} ; \mathrm{p} 90,90$ th percentile; $\mathrm{p} 75,75$ th percentile; $\mathrm{p} 50$, 50th percentile (median); p25, 25th percentile; p10, 10th percentile; specified period of analysis: por, period of record; cy, calendar year; wy, water year]

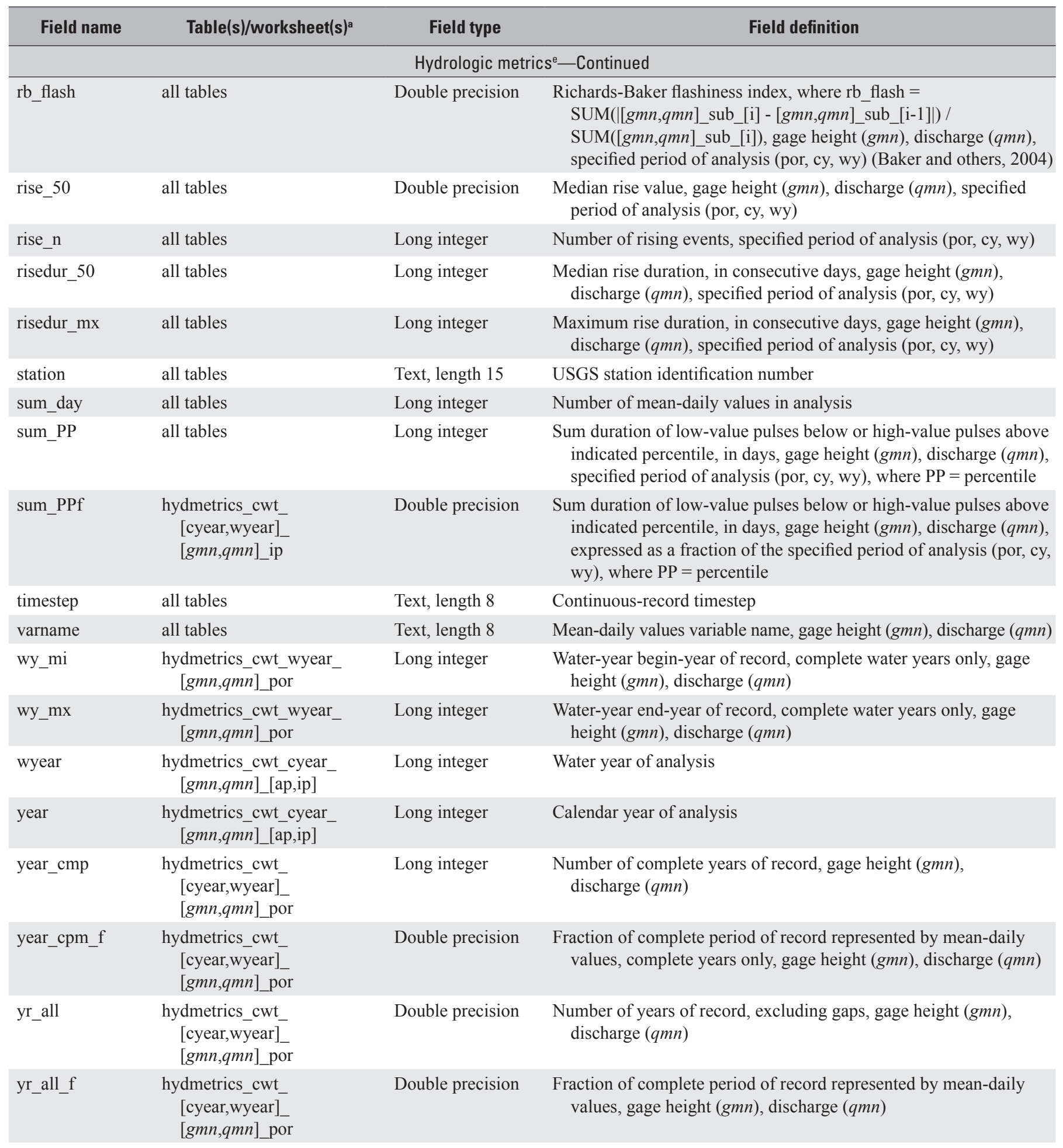


Table 4B. Database field names, field types, and field definitions for the hydrologic and landscape database for the Cache and White River National Wildlife Refuges contributing watersheds and vicinity, Arkansas, Missouri, and Oklahoma.-Continued

[USGS, U.S. Geological Survey; NAD 83, North American Datum of 1983; NGVD 29, National Geodetic Vertical Datum of 1929; FIPS, Federal Information Processing Standards; NLCD, National Land Cover Database; HSG, hydrologic soil group (U.S. Department of Agriculture, 2009, 2011b); calendar year, January 1 through December 31; water year,October 1, preceding calendar year, through September 30, current calendar year; calendar decade, 10-year period beginning on January 1 of year zero and ending on December 31 of year nine; $\mathrm{ft}^{3} \mathrm{~s}^{-1}$, cubic foot per second; $\mathrm{ft}^{3} \mathrm{~s}^{-1} \mathrm{mi}^{-2}$, cubic foot per second per square mile; $\mathrm{ft}$, foot; in, inch; $\mathrm{mi}^{2}$, square mile; gmn, mean-daily gage height, in ft; qmn, mean-daily discharge, in $\mathrm{ft}^{3} \mathrm{~s}^{-1} ; \mathrm{p} 90,90$ th percentile; $\mathrm{p} 75,75$ th percentile; $\mathrm{p} 50$, 50th percentile (median); p25, 25th percentile; p10, 10th percentile; specified period of analysis: por, period of record; cy, calendar year; wy, water year]

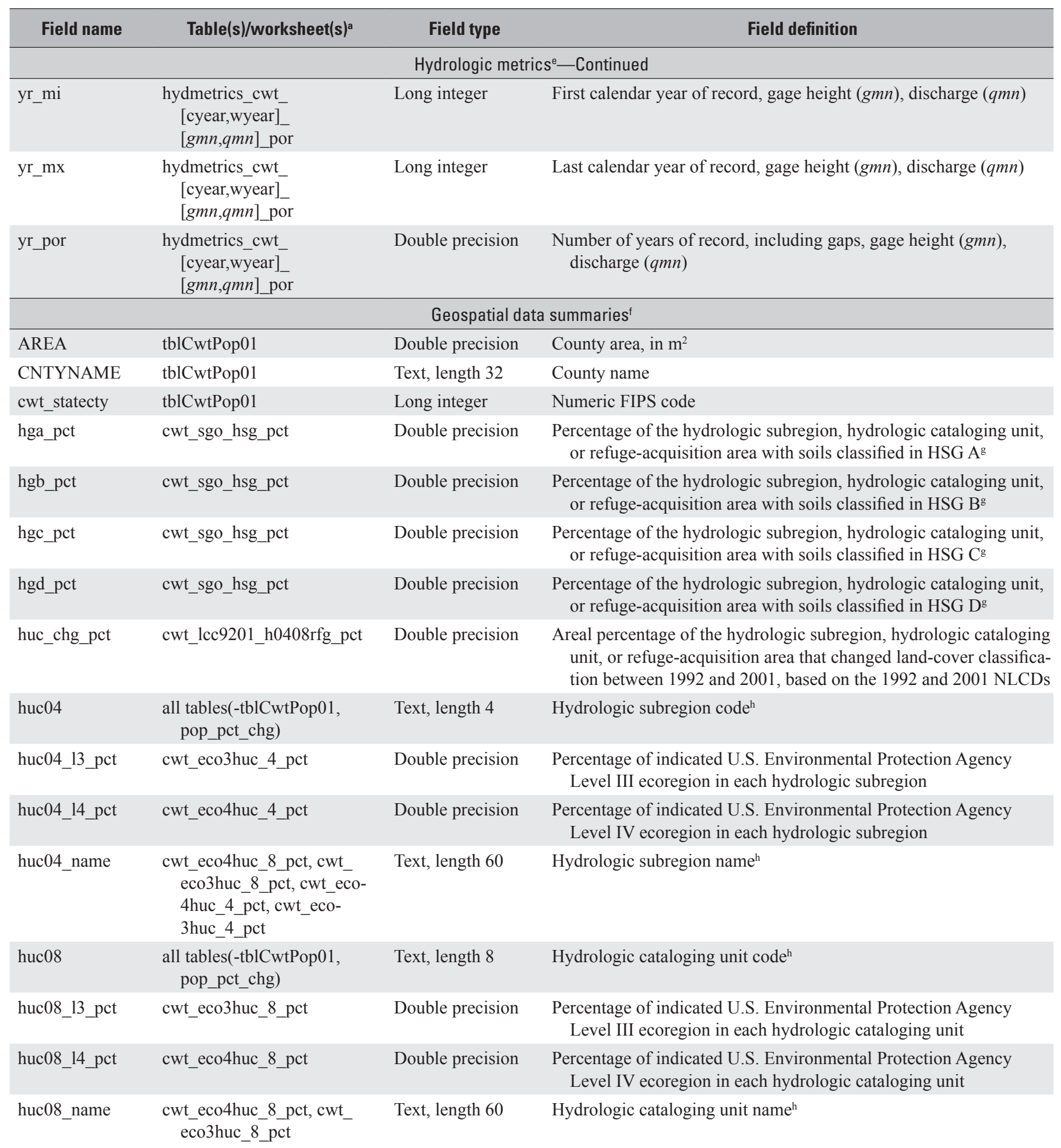


Table 4B. Database field names, field types, and field definitions for the hydrologic and landscape database for the Cache and White River National Wildlife Refuges contributing watersheds and vicinity, Arkansas, Missouri, and Oklahoma.-Continued

[USGS, U.S. Geological Survey; NAD 83, North American Datum of 1983; NGVD 29, National Geodetic Vertical Datum of 1929; FIPS, Federal Information Processing Standards; NLCD, National Land Cover Database; HSG, hydrologic soil group (U.S. Department of Agriculture, 2009, 2011b); calendar year, January 1 through December 31; water year,October 1, preceding calendar year, through September 30, current calendar year; calendar decade, 10 -year period beginning on January 1 of year zero and ending on December 31 of year nine; $\mathrm{ft}^{3} \mathrm{~s}^{-1}$, cubic foot per second; $\mathrm{ft}^{3} \mathrm{~s}^{-1} \mathrm{mi}^{-2}$, cubic foot per second per square mile; $\mathrm{ft}$, foot; in, inch; $\mathrm{mi}^{2}$, square mile; gmn, mean-daily gage height, in ft; qmn, mean-daily discharge, in $\mathrm{ft}^{3} \mathrm{~s}^{-1} ; \mathrm{p} 90,90$ th percentile; $\mathrm{p} 75,75$ th percentile; $\mathrm{p} 50$, 50th percentile (median); p25, 25th percentile; p10, 10th percentile; specified period of analysis: por, period of record; cy, calendar year; wy, water year]

\begin{tabular}{cccc}
\hline Field name & Table(s)/worksheet(s) ${ }^{\text {a }}$ & Field type & Field definition \\
\hline & Geospatial data summaries - Continued \\
\hline
\end{tabular}

mass_bal_cwt_lcc9201_h0408rfg_pct Double precision Sum-check for land-cover change net gain/loss percentages

\begin{tabular}{|c|c|c|c|}
\hline net_1 & cwt_lcc9201_h0408rfg_pct & Double precision & $\begin{array}{l}\text { Net percentage gain or loss of water within the area of the hydro- } \\
\text { logic subregion, hydrologic cataloging unit, or refuge- } \\
\text { acquisition area that changed land-cover classification between } \\
1992 \text { and 2001, based on the } 1992 \text { and } 2001 \text { NLCDs }\end{array}$ \\
\hline net_2 & cwt_lcc9201_h0408rfg_pct & Double precision & $\begin{array}{l}\text { Net percentage gain or loss of urban land within the area of the } \\
\text { hydrologic subregion, hydrologic cataloging unit, or refuge- } \\
\text { acquisition area that changed land-cover classification between } \\
1992 \text { and 2001, based on the } 1992 \text { and } 2001 \text { NLCDs }\end{array}$ \\
\hline
\end{tabular}

net_3 cwt_lcc9201_h0408rfg_pct Double precision $\quad \begin{array}{r}\text { Net percentage gain or loss of barren land within the area of the } \\ \text { hydrologic subregion, hydrologic cataloging unit, or refuge-a } \\ \text { cquisition area that changed land-cover classification between } \\ 1992 \text { and 2001, based on the 1992 and 2001 NLCDs }\end{array}$

net_4 cwt_lcc9201_h0408rfg_pct Double precision

Net percentage gain or loss of forest within the area of the hydrologic subregion, hydrologic cataloging unit, or refugeacquisition area that changed land-cover classification between 1992 and 2001, based on the 1992 and 2001 NLCDs

$\begin{array}{lll}\text { net_5 } & \text { cwt_lcc9201_h0408rfg_pct } & \text { Double precision } \\ \text { net_6 } & \text { cwt_lcc9201_h0408rfg_pct } & \text { Double precision }\end{array}$

\begin{tabular}{|c|c|c|}
\hline net_7 & cwt_lcc9201_h0408rfg_pct & Double precision \\
\hline nwr & $\begin{array}{l}\text { cwt_nlcd92_h0408rfg_pct, } \\
\text { cwt_nlcd01_h0408rfg_pct, } \\
\text { cwt_lcc9201_h0408rfg_ } \\
\text { pct, cwt_sgo_hsg_pct }\end{array}$ & Text, length 60 \\
\hline pct_11 & $\begin{array}{l}\text { cwt_nlcd92_h0408rfg_pct, } \\
\text { cwt_nlcd01_h0408rfg_pct }\end{array}$ & Double precision \\
\hline pct_21 & $\begin{array}{l}\text { cwt_nlcd92_h0408rfg_pct, } \\
\text { cwt_nlcd01_h0408rfg_pct }\end{array}$ & Double precision \\
\hline
\end{tabular}

Net percentage gain or loss of grassland within the area of the hydrologic subregion, hydrologic cataloging unit, or refugeacquisition area that changed land-cover classification between 1992 and 2001, based on the 1992 and 2001 NLCDs

Net percentage gain or loss of agricultural land within the area of the hydrologic subregion, hydrologic cataloging unit, or refugeacquisition area that changed land-cover classification between 1992 and 2001, based on the 1992 and 2001 NLCDs

Net percentage gain or loss of wetland within the area of the hydrologic subregion, hydrologic cataloging unit, or refuge-acquisition area that changed land-cover classification between 1992 and 2001, based on the 1992 and 2001 NLCDs

U.S. Fish and Wildlife Service National Wildlife Refuge name

Percent open water-all areas of open water, generally with less than 25 percent cover of vegetation or soil $(1992,2001)^{\mathrm{i}, \mathrm{j}}$

Percent developed-low-intensity residential (1992)i developed, open space-includes areas with a mixture of some constructed materials, but mostly vegetation in the form of lawn grasses. Impervious surfaces account for less than 20 percent of total cover. These areas most commonly include large-lot single-family housing units, parks, golf courses, and vegetation planted in developed settings for recreation, erosion control, or aesthetic purposes $(2001)^{\mathrm{j}}$ 
Table 4B. Database field names, field types, and field definitions for the hydrologic and landscape database for the Cache and White River National Wildlife Refuges contributing watersheds and vicinity, Arkansas, Missouri, and Oklahoma.-Continued

[USGS, U.S. Geological Survey; NAD 83, North American Datum of 1983; NGVD 29, National Geodetic Vertical Datum of 1929; FIPS, Federal Information Processing Standards; NLCD, National Land Cover Database; HSG, hydrologic soil group (U.S. Department of Agriculture, 2009, 2011b); calendar year, January 1 through December 31; water year,October 1, preceding calendar year, through September 30, current calendar year; calendar decade, 10-year period beginning on January 1 of year zero and ending on December 31 of year nine; $\mathrm{ft}^{3} \mathrm{~s}^{-1}$, cubic foot per second; $\mathrm{ft}^{3} \mathrm{~s}^{-1} \mathrm{mi}^{-2}$, cubic foot per second per square mile; $\mathrm{ft}$, foot; in, inch; $\mathrm{mi}^{2}$, square mile; gmn, mean-daily gage height, in ft; qmn, mean-daily discharge, in $\mathrm{ft}^{3} \mathrm{~s}^{-1} ; \mathrm{p} 90,90$ th percentile; $\mathrm{p} 75,75$ th percentile; $\mathrm{p} 50$, 50th percentile (median); p25, 25th percentile; p10, 10th percentile; specified period of analysis: por, period of record; cy, calendar year; wy, water year]

\begin{tabular}{|c|c|c|c|}
\hline Field name & Table(s)/worksheet(s) & Field type & Field definition \\
\hline pct_22 & $\begin{array}{l}\text { cwt_nlcd92_h0408rfg_pct, } \\
\text { cwt_nlcd01_h0408rfg_pct }\end{array}$ & Double precision & $\begin{array}{l}\text { Percent developed-high-intensity residential }(1992)^{\mathrm{i}} \text {; developed, } \\
\text { low intensity-includes areas with a mixture of constructed } \\
\text { materials and vegetation. Impervious surfaces account for } \\
20-49 \text { percent of total cover. These areas most commonly } \\
\text { include single-family housing units }(2001)^{\mathrm{j}}\end{array}$ \\
\hline pct_24 & cwt_nlcd01_h0408rfg_pct & Double precision & $\begin{array}{l}\text { Developed, high intensity_-includes highly developed areas } \\
\text { where people reside or work in high numbers. Examples include } \\
\text { apartment complexes, row houses and commercial/industrial. } \\
\text { Impervious surfaces account for } 80 \text { to } 100 \text { percent of the } \\
\text { total cover }(2001)^{\mathrm{j}}\end{array}$ \\
\hline pct_31 & $\begin{array}{l}\text { cwt_nlcd92_h0408rfg_pct, } \\
\text { cwt_nlcd01_h0408rfg_pct }\end{array}$ & Double precision & $\begin{array}{l}\text { Barren-bare rock/sand/clay (1992)i; barren land (rock/sand/clay)- } \\
\text { barren areas of bedrock, desert pavement, scarps, talus, slides, } \\
\text { volcanic material, glacial debris, sand dunes, strip mines, gravel } \\
\text { pits and other accumulations of earthen material. Generally, } \\
\text { vegetation accounts for less than } 15 \text { percent of total cover }(2001)^{j} \text {. }\end{array}$ \\
\hline pct_32 & cwt_nlcd92_h0408rfg_pct & Double precision & $\begin{array}{l}\text { Barren-quarries/strip mines/gravel pits }(1992)^{\mathrm{i}} \text {; unconsolidated } \\
\text { shorek-unconsolidated material such as silt, sand, or gravel that } \\
\text { is subject to inundation and redistribution due to the action of } \\
\text { water. Characterized by substrates lacking vegetation except for } \\
\text { pioneering plants that become established during brief periods } \\
\text { when growing conditions are favorable. Erosion and deposition } \\
\text { by waves and currents produce a number of landforms represent- } \\
\text { ing this class }(2001)^{j}\end{array}$ \\
\hline pct_42 & $\begin{array}{l}\text { cwt_nlcd92_h0408rfg_pct, } \\
\text { cwt_nlcd01_h0408rfg_pct }\end{array}$ & Double precision & $\begin{array}{l}\text { Vegetated, natural forested upland-evergreen forest }(1992)^{i} \text {; } \\
\text { evergreen forest-areas dominated by trees generally greater than } \\
5 \text { meters tall, and greater than } 20 \text { percent of total vegetation cover. } \\
\text { More than } 75 \text { percent of the tree species maintain their leaves all } \\
\text { year. Canopy is never without green foliage }(2001)^{j}\end{array}$ \\
\hline pct_43 & $\begin{array}{l}\text { cwt_nlcd92_h0408rfg_pct, } \\
\text { cwt_nlcd01_h0408rfg_pct }\end{array}$ & Double precision & $\begin{array}{l}\text { Vegetated, natural forested upland-mixed forest }(1992)^{\mathrm{i}} \text {; mixed } \\
\text { forest—areas dominated by trees generally greater than } 5 \text { meters } \\
\text { tall, and greater than } 20 \text { percent of total vegetation cover. Neither } \\
\text { deciduous nor evergreen species are greater than } 75 \text { percent of } \\
\text { total tree cover }(2001)^{\mathrm{j}}\end{array}$ \\
\hline pct_51 & cwt_nlcd92_h0408rfg_pct & Double precision & Shrubland (1992) ${ }^{\mathrm{i}}$ \\
\hline
\end{tabular}


Table 4B. Database field names, field types, and field definitions for the hydrologic and landscape database for the Cache and White River National Wildlife Refuges contributing watersheds and vicinity, Arkansas, Missouri, and Oklahoma.-Continued

[USGS, U.S. Geological Survey; NAD 83, North American Datum of 1983; NGVD 29, National Geodetic Vertical Datum of 1929; FIPS, Federal Information Processing Standards; NLCD, National Land Cover Database; HSG, hydrologic soil group (U.S. Department of Agriculture, 2009, 2011b); calendar year, January 1 through December 31; water year,October 1, preceding calendar year, through September 30, current calendar year; calendar decade, 10-year period beginning on January 1 of year zero and ending on December 31 of year nine; $\mathrm{ft}^{3} \mathrm{~s}^{-1}$, cubic foot per second; $\mathrm{ft}^{3} \mathrm{~s}^{-1} \mathrm{mi}^{-2}$, cubic foot per second per square mile; $\mathrm{ft}$, foot; in, inch; $\mathrm{mi}^{2}$, square mile; gmn, mean-daily gage height, in ft; qmn, mean-daily discharge, in $\mathrm{ft}^{3} \mathrm{~s}^{-1} ; \mathrm{p} 90,90$ th percentile; $\mathrm{p} 75,75$ th percentile; $\mathrm{p} 50$, 50th percentile (median); p25, 25th percentile; p10, 10th percentile; specified period of analysis: por, period of record; cy, calendar year; wy, water year]

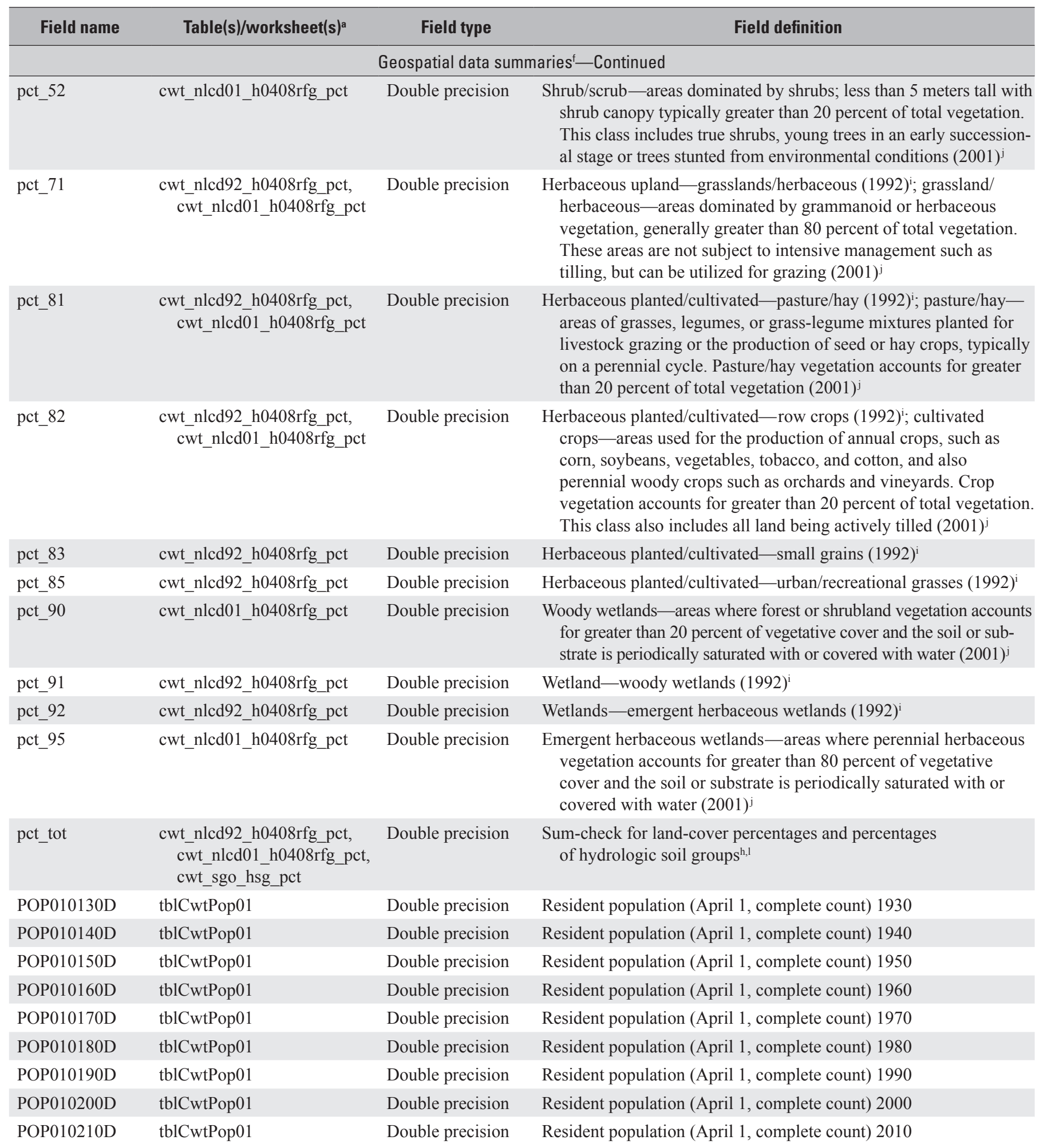


Table 4B. Database field names, field types, and field definitions for the hydrologic and landscape database for the Cache and White River National Wildlife Refuges contributing watersheds and vicinity, Arkansas, Missouri, and Oklahoma.-Continued

[USGS, U.S. Geological Survey; NAD 83, North American Datum of 1983; NGVD 29, National Geodetic Vertical Datum of 1929; FIPS, Federal Information Processing Standards; NLCD, National Land Cover Database; HSG, hydrologic soil group (U.S. Department of Agriculture, 2009, 2011b); calendar year, January 1 through December 31; water year,October 1, preceding calendar year, through September 30, current calendar year; calendar decade, 10-year period beginning on January 1 of year zero and ending on December 31 of year nine; $\mathrm{ft}^{3} \mathrm{~s}^{-1}$, cubic foot per second; $\mathrm{ft}^{3} \mathrm{~s}^{-1} \mathrm{mi}^{-2}$, cubic foot per second per square mile; $\mathrm{ft}$, foot; in, inch; $\mathrm{mi}^{2}$, square mile; gmn, mean-daily gage height, in ft; qmn, mean-daily discharge, in $\mathrm{ft}^{3} \mathrm{~s}^{-1} ; \mathrm{p} 90,90$ th percentile; $\mathrm{p} 75,75$ th percentile; $\mathrm{p} 50$, 50th percentile (median); p25, 25th percentile; p10, 10th percentile; specified period of analysis: por, period of record; cy, calendar year; wy, water year]

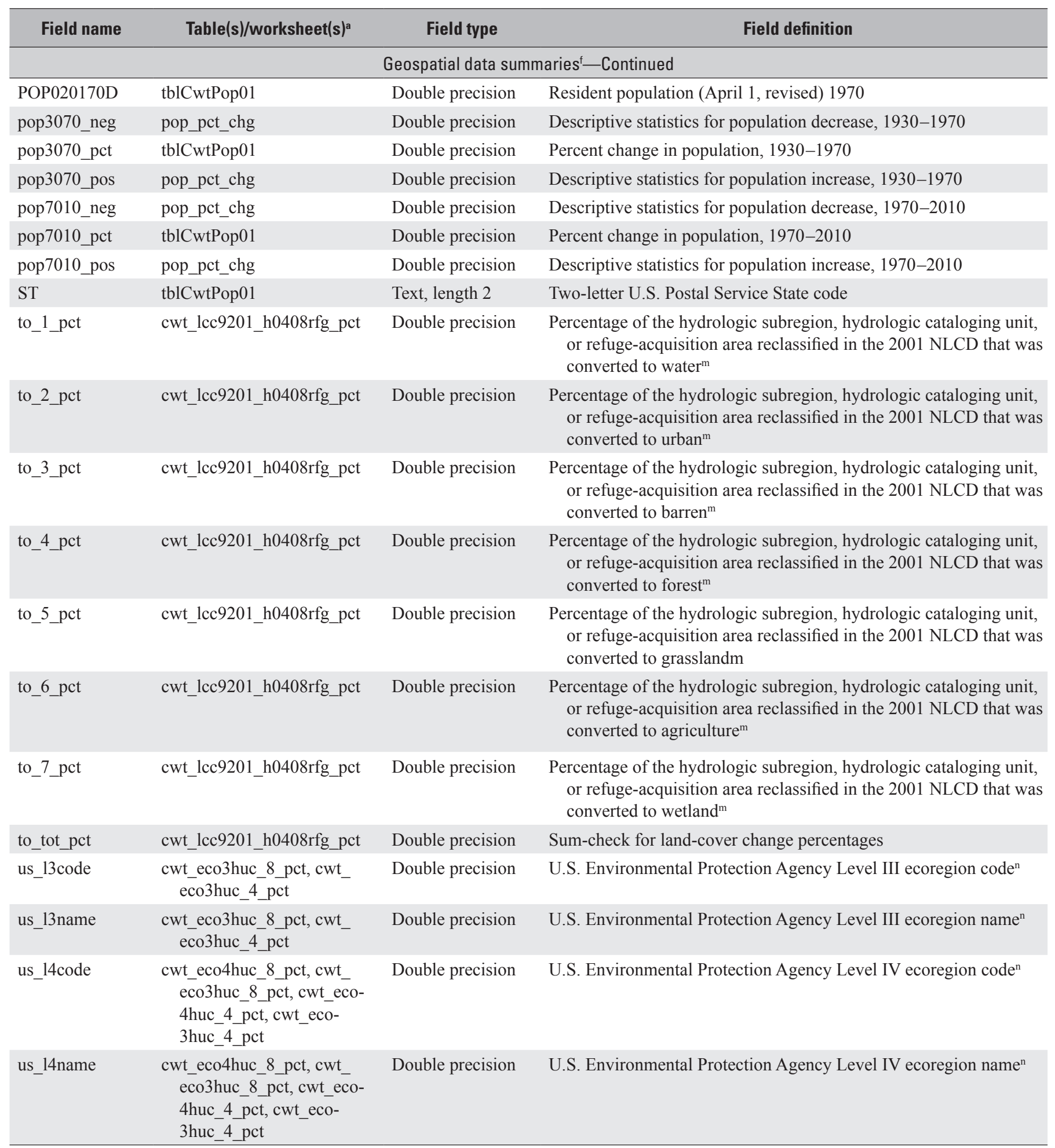


Table 4B. Database field names, field types, and field definitions for the hydrologic and landscape database for the Cache and White River National Wildlife Refuges contributing watersheds and vicinity, Arkansas, Missouri, and Oklahoma._-Continued

[USGS, U.S. Geological Survey; NAD 83, North American Datum of 1983; NGVD 29, National Geodetic Vertical Datum of 1929; FIPS, Federal Information Processing Standards; NLCD, National Land Cover Database; HSG, hydrologic soil group (U.S. Department of Agriculture, 2009, 2011b); calendar year, January 1 through December 31; water year,October 1, preceding calendar year, through September 30, current calendar year; calendar decade, 10-year period beginning on January 1 of year zero and ending on December 31 of year nine; $\mathrm{ft}^{3} \mathrm{~s}^{-1}$, cubic foot per second; $\mathrm{ft}^{3} \mathrm{~s}^{-1} \mathrm{mi}^{-2}$, cubic foot per second per square mile; $\mathrm{ft}$, foot; in, inch; $\mathrm{mi}^{2}$, square mile; gmn, mean-daily gage height, in ft; qmn, mean-daily discharge, in $\mathrm{ft}^{3} \mathrm{~s}^{-1} ; \mathrm{p} 90,90$ th percentile; $\mathrm{p} 75,75$ th percentile; $\mathrm{p} 50$, 50th percentile (median); p25, 25th percentile; p10, 10th percentile; specified period of analysis: por, period of record; cy, calendar year; wy, water year]

\section{$\begin{array}{llll}\text { Field name } & \text { Table(s)/worksheet(s) }{ }^{\text {a }} \quad \text { Field type } & \text { Field definition }\end{array}$}

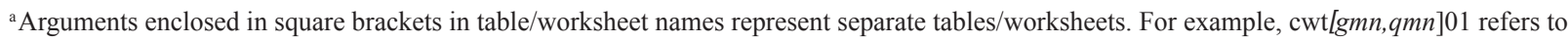
2 tables/worksheets: cwtgmn01 and cwtqmn01. "All tables" with one or more table/worksheet names in parentheses indicates that the table/worksheet reference(s) in parentheses is(are) excluded for the listed field. Tables refer to Microsoft Access ${ }^{\circledR}$ files, worksheets refer to Microsoft Excel ${ }^{\circledR}$ files.

${ }^{b}$ Raw-data files: cwt_tabular_hydrostats_raw.accdb (Microsoft Access $®$ ), cwt_tabular_hydrostats_raw.xlsx (Microsoft Excel $($ ) $)$.

${ }^{\text {c}}$ Data-value qualification codes, USGS NWISWeb database (U.S. Geological Survey, 2002, 2011b,c): Eqp — equipment malfunction, A—approved for publication-processing and review completed, $\mathrm{P}$ - provisional data subject to revision, 1 - daily value is write-protected without any remark code to be printed, e-value has been estimated.

${ }^{\mathrm{d}}$ Descriptive-statistics, spread-measures, and ratio-measures files: cwt_tabular_hydrostats.accdb (Microsoft Access $®$ ); cwt_tabular_hydrostats_[gmn,qmn]. xlsx (Microsoft Excel®).

${ }^{\mathrm{e}}$ Hydrologic-metrics files: cwt_tabular_hydmetrics.accdb (Microsoft Access $\left.{ }^{\circledR}\right)$, cwt_tabular_hydmetrics.xlsx (Microsoft Excel®).

${ }^{\mathrm{f}}$ Geospatial data summaries files: cwt_nlcd.xlsx, cwt_sgo_hsg.xlsx, cwt_eco34.xlsx, cwt_pop_census.xlsx (Microsoft Excel®).

g U.S. Department of Agriculture, 2009, 2011 b.

${ }^{\mathrm{h}}$ Seaber and others, 1994.

${ }^{\mathrm{i} U . S . ~ G e o l o g i c a l ~ S u r v e y, ~} 2008 \mathrm{f}$.

${ }^{j}$ Multi-Resolution Land Characteristics Consortium (MRLC), 2011a.

${ }^{\mathrm{k}}$ Coastal NLCD class only.

${ }^{1}$ Percentages of hydrologic soil groups A through D in hydrologic subregions and cataloging units do not necessarily add up to 100 percent because, in some cases, there are STATSGO soil map-unit classifications that include multiple hydrologic soil groups (U.S. Department of Agriculture, 2009, 2011b). Data for multiple-group map units are not included in the analysis.

${ }^{\mathrm{m}}$ Fry and others, 2008; Multi-Resolution Land Characteristics Consortium (MRLC), 2011b.

${ }^{\mathrm{n}}$ U.S. Environmental Protection Agency, 2011. 
Table 5. Indicators of Hydrologic Alteration (IHA) hydrologic-parameter groups, environmental-flow-component groups, and parameter and component definitions used in the Cache and White River National Wildlife Refuge IHA analysis (modified from Richter and others, 1996; The Nature Conservancy, 2007, 2009).

[IHA parameter-group definitions, environmental-flow-component group definitions, and parameter and component definitions listed in Richter and others (1996) and The Nature Conservancy (2009); parameter group 1, magnitude of monthly water conditions; parameter group 2, magnitude and duration of annual extreme water conditions; parameter group 3, timing of annual extreme water conditions; parameter group 4, frequency and duration of high and low pulses; parameter group 5, rate and frequency of water-condition changes; environmental-flow component (EFC) group 1, monthly low flows; EFC group 2, extreme low flows; EFC group 3, high-flow pulses; EFC group 4, small floods; EFC group 5, large floods; all analyses are done on a water-year basis (October 1, previous calendar year, through September 30, current calendar year)]

\begin{tabular}{|c|c|c|}
\hline $\begin{array}{l}\text { Parameter group/ } \\
\text { EFC group }\end{array}$ & Parameter/component name & Parameter/component definition \\
\hline \multicolumn{3}{|c|}{ Hydrologic Parameter groups } \\
\hline Parameter group 1 & November & Water-year annual monthly-median value for November \\
\hline Parameter group 1 & December & Water-year annual monthly-median value for December \\
\hline Parameter group 1 & February & Water-year annual monthly-median value for February \\
\hline Parameter group 1 & March & Water-year annual monthly-median value for March \\
\hline Parameter group 1 & April & Water-year annual monthly-median value for April \\
\hline Parameter group 1 & May & Water-year annual monthly-median value for May \\
\hline Parameter group 1 & September & Water-year annual monthly-median value for September \\
\hline Parameter group 2 & 1-day minimum & Water-year annual minimum 1-day mean value \\
\hline Parameter group 2 & 3-day minimum & Water-year annual minimum 3-day mean value \\
\hline Parameter group 2 & 7-day minimum & Water-year annual minimum 7-day mean value \\
\hline Parameter group 2 & 30-day minimum & Water-year annual minimum 30-day mean value \\
\hline Parameter group 2 & 90-day minimum & Water-year annual minimum 90-day mean value \\
\hline Parameter group 2 & 1-day maximum & Water-year annual maximum 1-day mean value \\
\hline Parameter group 2 & 3-day maximum & Water-year annual maximum 3-day mean value \\
\hline Parameter group 3 & Date of minimum & Julian date of water-year annual minimum 1-day mean value \\
\hline Parameter group 3 & Date of maximum & Julian date of water-year annual maximum 1-day mean value \\
\hline Parameter group $4^{\mathrm{a}}$ & Low-pulse count & Water-year annual number of low pulses \\
\hline Parameter group $4^{\mathrm{a}}$ & Low-pulse duration & Water-year annual median duration of low pulses \\
\hline Parameter group $4^{\mathrm{a}}$ & High-pulse count & Water-year annual number of high pulses \\
\hline Parameter group $4^{\mathrm{a}}$ & High-pulse duration & Water-year annual median duration of high pulses \\
\hline Parameter group 5 & Rise rate & Water-year annual median positive difference in mean-daily values \\
\hline Parameter group 5 & Fall rate & Water-year annual median negative difference in mean-daily values \\
\hline Parameter group 5 & Number of reversals & Water-year annual number of hydrologic reversals (hydrograph sign changes) \\
\hline
\end{tabular}


Table 5. Indicators of Hydrologic Alteration (IHA) hydrologic-parameter groups, environmental-flow-component groups, and parameter and component definitions used in the Cache and White River National Wildlife Refuge IHA analysis (modified from Richter and others, 1996; The Nature Conservancy, 2007, 2009).-Continued

[IHA parameter-group definitions, environmental-flow-component group definitions, and parameter and component definitions listed in Richter and others (1996) and The Nature Conservancy (2009); parameter group 1, magnitude of monthly water conditions; parameter group 2, magnitude and duration of annual extreme water conditions; parameter group 3, timing of annual extreme water conditions; parameter group 4, frequency and duration of high and low pulses; parameter group 5, rate and frequency of water-condition changes; environmental-flow component (EFC) group 1, monthly low flows; EFC group 2, extreme low flows; EFC group 3, high-flow pulses; EFC group 4, small floods; EFC group 5, large floods; all analyses are done on a water-year basis (October 1, previous calendar year, through September 30, current calendar year)]

\begin{tabular}{|c|c|c|}
\hline $\begin{array}{l}\text { Parameter group/ } \\
\text { EFC group }\end{array}$ & Parameter/component name & Parameter/component definition \\
\hline \multicolumn{3}{|c|}{ Environmental-flow component groups } \\
\hline EFC group $1^{\text {b }}$ & October low flow & Water-year annual median value of October low flows \\
\hline EFC group $1^{b}$ & November low flow & Water-year annual median value of November low flows \\
\hline EFC group $1^{b}$ & December low flow & Water-year annual median value of December low flows \\
\hline EFC group $1^{\mathrm{b}}$ & January low flow & Water-year annual median value of January low flows \\
\hline EFC group $1^{\mathrm{b}}$ & February low flow & Water-year annual median value of February low flows \\
\hline EFC group $1^{\mathrm{b}}$ & March low flow & Water-year annual median value of March low flows \\
\hline EFC group $1^{\mathrm{b}}$ & April low flow & Water-year annual median value of April low flows \\
\hline EFC group $1^{b}$ & May low flow & Water-year annual median value of May low flows \\
\hline EFC group $1^{\mathrm{b}}$ & June low flow & Water-year annual median value of June low flows \\
\hline EFC group $1^{\mathrm{b}}$ & July low flow & Water-year annual median value of July low flows \\
\hline EFC group $1^{\mathrm{b}}$ & August low Flow & Water-year annual median value of August low flows \\
\hline EFC group $1^{b}$ & September low flow & Water-year annual median value of September low flows \\
\hline EFC group $2^{\mathrm{c}}$ & Extreme low-flow duration & Water-year annual median duration of an extreme low-flow event \\
\hline EFC group $2^{c}$ & Extreme low-flow peak & Water-year annual median minimum value during an extreme low-flow event \\
\hline EFC group $2^{c}$ & Extreme low-flow timing & $\begin{array}{l}\text { Water-year annual median Julian date of minimum value during an extreme } \\
\text { low-flow event }\end{array}$ \\
\hline EFC group $2^{c}$ & Extreme low-flow frequency & Water-year annual number of extreme low-flow events \\
\hline EFC group $3^{\mathrm{d}}$ & High-flow pulse duration & Water-year annual median duration of a high-flow pulse event \\
\hline EFC group $3^{\mathrm{d}}$ & High-flow pulse peak & Water-year annual median minimum value during a high-flow pulse event \\
\hline EFC group $3^{d}$ & High-flow pulse timing & $\begin{array}{l}\text { Water-year annual median Julian date of minimum value during a high-flow } \\
\text { pulse event }\end{array}$ \\
\hline EFC group $3^{d}$ & High-flow pulse frequency & Water-year annual number of high-flow pulse events \\
\hline EFC group $3^{d}$ & high-flow pulse rise rate & $\begin{array}{l}\text { Water-year annual median rise rate of high-flow pulse events-median value } \\
\text { of the median positive difference in mean-daily values for each high-flow } \\
\text { pulse event }\end{array}$ \\
\hline EFC group $3^{d}$ & High-flow pulse fall rate & $\begin{array}{l}\text { Water-year annual median fall rate of high-flow pulse events-median value } \\
\text { of the median negative difference in mean-daily values for each high-flow } \\
\text { pulse event }\end{array}$ \\
\hline EFC group $4^{\mathrm{e}}$ & Small-flood duration & Water-year annual median duration of a small-flood event \\
\hline EFC group $4^{e}$ & Small-flood peak & Water-year annual median minimum value during a small-flood event \\
\hline EFC group $4^{e}$ & Small-flood timing & $\begin{array}{l}\text { Water-year annual median Julian date of minimum value during a } \\
\text { small-flood event }\end{array}$ \\
\hline EFC group $4^{e}$ & Small-flood frequency & Water-year annual number of small-flood events \\
\hline EFC group $4^{\mathrm{e}}$ & Small-flood rise rate & $\begin{array}{l}\text { Water-year annual median rise rate of small-flood events - median value of the } \\
\text { median positive difference in mean-daily values for each small-flood event }\end{array}$ \\
\hline EFC group $4^{e}$ & Small-flood fall rate & $\begin{array}{l}\text { Water-year annual median fall rate of small-flood events - median value of the } \\
\text { median negative difference in mean-daily values for each small-flood event }\end{array}$ \\
\hline
\end{tabular}


Table 5. Indicators of Hydrologic Alteration (IHA) hydrologic-parameter groups, environmental-flow-component groups, and parameter and component definitions used in the Cache and White River National Wildlife Refuge IHA analysis (modified from Richter and others, 1996; The Nature Conservancy, 2007, 2009).-Continued

[IHA parameter-group definitions, environmental-flow-component group definitions, and parameter and component definitions listed in Richter and others (1996) and The Nature Conservancy (2009); parameter group 1, magnitude of monthly water conditions; parameter group 2, magnitude and duration of annual extreme water conditions; parameter group 3, timing of annual extreme water conditions; parameter group 4, frequency and duration of high and low pulses; parameter group 5, rate and frequency of water-condition changes; environmental-flow component (EFC) group 1, monthly low flows; EFC group 2, extreme low flows; EFC group 3, high-flow pulses; EFC group 4, small floods; EFC group 5, large floods; all analyses are done on a water-year basis (October 1, previous calendar year, through September 30, current calendar year)]

\begin{tabular}{|c|c|c|}
\hline $\begin{array}{l}\text { Parameter group/ } \\
\text { EFC group }\end{array}$ & Parameter/component name & Parameter/component definition \\
\hline \multicolumn{3}{|c|}{ Environmental-flow component groups-Continued } \\
\hline EFC group $5^{\mathrm{f}}$ & Large-flood peak & Water-year annual median minimum value during a large-flood event \\
\hline EFC group $5^{\mathrm{f}}$ & Large-flood timing & $\begin{array}{l}\text { Water-year annual median Julian date of minimum value during a } \\
\text { large-flood event }\end{array}$ \\
\hline EFC group $5^{\mathrm{f}}$ & Large-flood rise rate & $\begin{array}{l}\text { Water-year annual median rise rate of large-flood events-median value of the } \\
\text { median positive difference in mean-daily values for each large-flood event }\end{array}$ \\
\hline EFC group $5^{\mathrm{f}}$ & Large-flood fall rate & $\begin{array}{l}\text { Water-year annual median fall rate of large-flood events - median value of the } \\
\text { median negative difference in mean-daily values for each large-flood event }\end{array}$ \\
\hline
\end{tabular}

${ }^{\text {a }}$ The low-pulse threshold is the 50th percentile of the mean-daily flows minus 25 percent. If the low-pulse threshold is zero, for any given day, the value for that day is reset to the 25 th percentile of the mean-daily flows. The high-pulse threshold is the 50th percentile of the mean-daily flows plus 25 percent.

${ }^{\mathrm{b}}$ The low-flow threshold is the median value (50th percentile) of the mean-daily flows. All values less than this threshold are classified as low flows. Additionally, mean-daily values between the 50th and 75th percentiles-low-flow and high-flow thresholds - are also classified as low flows if a daily value within this range does not meet the filtering criteria for a high-flow value (reference footnote $\mathrm{d}$ ).

${ }^{c}$ The extreme low-flow threshold is the 10th percentile of the mean-daily low flows. All values less than this threshold are classified as extreme low flows.

${ }^{d}$ High-flow pulses are mean-daily values that have been classified as high flows but not classified as either small floods or large floods. The initial high-flow classification is based on the high-flow threshold of the 75th percentile of the mean-daily flows. All values greater than this threshold value are classified as high flows. Additionally, mean-daily values between the 50th and 75th percentiles-low-flow and high-flow thresholds - are also classified as high flows if a daily value exceeds the high-flow start-rate threshold (more than 25 percent greater than the value for the preceding day), is on the ascending limb of a high-flow event (either greater than or equal to the high-flow value for the preceding day or above the high-flow end-rate threshold-less than 10 percent less than the value for the preceding day), or is on the descending limb of a high-flow event and has not exceeded the high-flow end-rate threshold (more than 10 percent less than the value for the preceding day).

${ }^{\mathrm{e}}$ Small floods are high-flow values that have a period-of-record recurrence interval greater than 2 years and less than or equal to 10 years.

${ }^{\mathrm{f}}$ Large floods are high-flow values that have a period-of-record recurrence interval greater than 10 years. 
Table 6A. Summary descriptive statistics and percentiles for gage height by water year for gaging stations in the contributing watersheds of the Cache and White River National Wildlife Refuges and vicinity, Arkansas, Missouri, and Oklahoma.

[Major drainage boundaries and locations of U.S. Geological Survey (USGS) gaging stations shown in figure 1; USGS hydrologic subregions, and subregion hydrologic-unit codes, listed as subheadings and also shown in figure 1; Min, minimum value; Max, maximum value; - , too few values to compute the indicated percentile; water year, October 1, preceding calendar year, through September 30, current calendar year]

\begin{tabular}{|c|c|c|c|c|c|c|c|c|c|c|c|c|c|c|}
\hline $\begin{array}{l}\text { USGS } \\
\text { station } \\
\text { number }\end{array}$ & $\begin{array}{l}\text { River } \\
\text { name }\end{array}$ & $\begin{array}{l}\text { Period } \\
\text { of } \\
\text { record }^{a}\end{array}$ & \multicolumn{3}{|c|}{$\begin{array}{l}\text { Mean-annual } \\
\text { gage height, } \\
\text { in feet }^{b}\end{array}$} & \multicolumn{2}{|c|}{$\begin{array}{l}\text { Mean-daily } \\
\text { gage height, } \\
\text { in feet }^{b}\end{array}$} & \multicolumn{7}{|c|}{$\begin{array}{l}\text { Percentiles of mean-annual gage height and } \\
\text { (mean-daily gage height), } \\
\text { in feet }{ }^{\mathrm{c}}\end{array}$} \\
\hline \multicolumn{15}{|c|}{ Upper White (1101) } \\
\hline 07074500 & $\begin{array}{l}\text { White } \\
\text { River }\end{array}$ & $\begin{array}{c}1978- \\
2009 \\
(7)\end{array}$ & 9.71 & $\begin{array}{c}3.68 \\
(2000)\end{array}$ & $\begin{array}{c}17.19 \\
(1985)\end{array}$ & $\begin{array}{c}-1.79 \\
(1988)\end{array}$ & $\begin{array}{c}33.31 \\
(1983)\end{array}$ & $\overline{(0.00)}$ & $\overline{(0.84)}$ & $\begin{array}{c}4.98 \\
(2.92)\end{array}$ & $\begin{array}{c}9.26 \\
(8.28)\end{array}$ & $\begin{array}{c}12.43 \\
(15.18)\end{array}$ & $-\overline{(25.12)}$ & $(24.12)$ \\
\hline \multicolumn{15}{|c|}{ Lower Mississippi-St Francis (0802) } \\
\hline 07077000 & $\begin{array}{l}\text { White } \\
\text { River }\end{array}$ & $\begin{array}{c}1989- \\
2009 \\
(4)\end{array}$ & 12.72 & $\begin{array}{c}5.90 \\
(2001)\end{array}$ & $\begin{array}{l}15.70 \\
(1997)\end{array}$ & $\begin{array}{c}-0.72 \\
(2001)\end{array}$ & $\begin{array}{l}25.35 \\
(1997)\end{array}$ & $\overline{(1.86)}$ & $(2.59)$ & $(\overline{5.75)}$ & $\begin{array}{c}14.65 \\
(13.07)\end{array}$ & $(\overline{20.32)}$ & $(22.31)$ & $(23.27)$ \\
\hline 07077380 & $\begin{array}{l}\text { Cache } \\
\text { River }\end{array}$ & $\begin{array}{c}1974- \\
2009 \\
(14)\end{array}$ & 8.32 & $\begin{array}{c}5.50 \\
(1981)\end{array}$ & $\begin{array}{c}10.90 \\
(1985)\end{array}$ & $\begin{array}{c}2.42 \\
(1981)\end{array}$ & $\begin{array}{c}21.18 \\
(1979)\end{array}$ & $\overline{(3.36)}$ & $\begin{array}{c}5.77 \\
(3.85)\end{array}$ & $\begin{array}{c}6.60 \\
(5.06)\end{array}$ & $\begin{array}{c}8.77 \\
(6.80)\end{array}$ & $\begin{array}{c}9.72 \\
(10.56)\end{array}$ & $\begin{array}{c}10.59 \\
(16.11)\end{array}$ & $\overline{(17.80)}$ \\
\hline 07077555 & $\begin{array}{l}\text { Cache } \\
\text { River }\end{array}$ & $\begin{array}{l}1987- \\
2009 \\
(12)\end{array}$ & 10.41 & $\begin{array}{c}8.50 \\
(2001)\end{array}$ & $\begin{array}{c}13.01 \\
(1989)\end{array}$ & $\begin{array}{c}3.07 \\
(2001)\end{array}$ & $\begin{array}{c}20.18 \\
(1988)\end{array}$ & $(\overline{4.20)}$ & $\begin{array}{c}9.26 \\
(4.79)\end{array}$ & $\begin{array}{c}9.81 \\
(6.24)\end{array}$ & $\begin{array}{l}10.13 \\
(9.49)\end{array}$ & $\begin{array}{c}11.07 \\
(14.34)\end{array}$ & $\begin{array}{c}11.81 \\
(17.48)\end{array}$ & $\begin{array}{c}13.01 \\
(18.57)\end{array}$ \\
\hline 07077700 & $\begin{array}{l}\text { Bayou } \\
\text { DeView }\end{array}$ & $\begin{array}{l}1987- \\
2009 \\
(5)\end{array}$ & 14.60 & $\begin{array}{c}13.84 \\
(2000)\end{array}$ & $\begin{array}{l}15.38 \\
(2002)\end{array}$ & $\begin{array}{c}9.51 \\
(1998)\end{array}$ & $\begin{array}{l}18.78 \\
(2002)\end{array}$ & $(12.22)$ & $\overline{(12.68)}$ & $\begin{array}{c}14.50 \\
(13.38)\end{array}$ & $\begin{array}{c}14.59 \\
(14.23)\end{array}$ & $\begin{array}{c}14.71 \\
(15.86)\end{array}$ & $\overline{(17.24)}$ & $\overline{-}(17.65)$ \\
\hline 07077800 & $\begin{array}{l}\text { White } \\
\text { River }\end{array}$ & $\begin{array}{c}1886- \\
2009 \\
(80)\end{array}$ & 17.77 & $\begin{array}{c}11.21 \\
(1902)\end{array}$ & $\begin{array}{l}25.42 \\
(1927)\end{array}$ & $\begin{array}{c}1.00 \\
(1998)\end{array}$ & $\begin{array}{l}43.30 \\
(1927)\end{array}$ & $\begin{array}{l}12.55 \\
(7.10)\end{array}$ & $\begin{array}{l}13.34 \\
(8.20)\end{array}$ & $\begin{array}{c}15.33 \\
(11.20)\end{array}$ & $\begin{array}{c}17.80 \\
(17.40)\end{array}$ & $\begin{array}{c}20.20 \\
(24.50)\end{array}$ & $\begin{array}{c}22.02 \\
(27.50)\end{array}$ & $\begin{array}{c}23.29 \\
(28.70)\end{array}$ \\
\hline 07077820 & $\begin{array}{l}\text { White } \\
\text { River }\end{array}$ & $\begin{array}{c}1932- \\
2009 \\
(44)\end{array}$ & 17.41 & $\begin{array}{c}11.03 \\
(2000)\end{array}$ & $\begin{array}{l}24.46 \\
(1973)\end{array}$ & $\begin{array}{c}1.00 \\
(1995)\end{array}$ & $\begin{array}{l}40.10 \\
(1937)\end{array}$ & $\begin{array}{l}11.63 \\
(7.50)\end{array}$ & $\begin{array}{l}12.92 \\
(8.50)\end{array}$ & $\begin{array}{c}14.77 \\
(11.00)\end{array}$ & $\begin{array}{c}17.88 \\
(17.10)\end{array}$ & $\begin{array}{c}19.81 \\
(23.80)\end{array}$ & $\begin{array}{c}21.40 \\
(26.00)\end{array}$ & $\begin{array}{c}21.90 \\
(28.00)\end{array}$ \\
\hline \multicolumn{15}{|c|}{ Lower Arkansas (1111) } \\
\hline 07263500 & $\begin{array}{c}\text { Akansas } \\
\text { River }\end{array}$ & $\begin{array}{l}1987- \\
2009 \\
(6)\end{array}$ & 8.40 & $\begin{array}{c}7.30 \\
(2006)\end{array}$ & $\begin{array}{c}9.57 \\
(1999)\end{array}$ & $\begin{array}{c}6.74 \\
(1999)\end{array}$ & $\begin{array}{c}18.52 \\
(1998)\end{array}$ & $(\overline{7.12})$ & $(\overline{7.25)}$ & $\begin{array}{c}7.92 \\
(7.45)\end{array}$ & $\begin{array}{c}8.43 \\
(7.62)\end{array}$ & $\begin{array}{c}8.76 \\
(8.20)\end{array}$ & $(11.54)$ & $(\overline{-})$ \\
\hline \multicolumn{15}{|c|}{ Lower Mississippi-Yazoo (0803) } \\
\hline 07265450 & $\begin{array}{l}\text { Mississippi } \\
\text { River }\end{array}$ & $\begin{array}{c}1929- \\
2009 \\
(70)\end{array}$ & 16.64 & $\begin{array}{c}6.33 \\
(1954)\end{array}$ & $\begin{array}{l}27.00 \\
(1935)\end{array}$ & $\begin{array}{c}-5.10 \\
(1936)\end{array}$ & $\begin{array}{c}53.90 \\
(1937)\end{array}$ & $\begin{array}{c}7.83 \\
(1.10)\end{array}$ & $\begin{array}{c}9.72 \\
(3.20)\end{array}$ & $\begin{array}{l}13.12 \\
(7.40)\end{array}$ & $\begin{array}{c}16.65 \\
(15.10)\end{array}$ & $\begin{array}{c}20.03 \\
(24.60)\end{array}$ & $\begin{array}{c}23.31 \\
(32.50)\end{array}$ & $\begin{array}{c}25.23 \\
(36.50)\end{array}$ \\
\hline
\end{tabular}

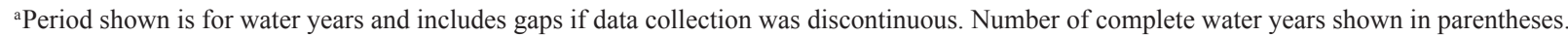

${ }^{\text {b}}$ Statistics listed for mean-annual and mean-daily gage height are based on complete water years. Year of minimum and maximum values for meanannual and mean-daily gage-height numbers shown in parentheses.

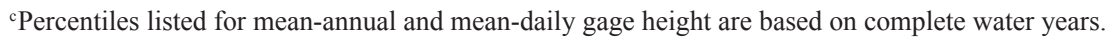

${ }^{\mathrm{d} I n a c t i v e ~ s t a t i o n . ~}$ 
Table 6B. Summary descriptive statistics and percentiles for gage height by calendar year for gaging stations in the contributing watersheds of the Cache and White River National Wildlife Refuges and vicinity, Arkansas, Missouri, and Oklahoma.

[Major drainage boundaries and locations of U.S. Geological Survey (USGS) gaging stations shown in figure 1; USGS hydrologic subregions, and subregion hydrologic-unit codes, listed as subheadings and also shown in figure 1; Min, minimum value; Max, maximum value; - , too few values to compute the indicated percentile; calendar year, January 1 through December 31]

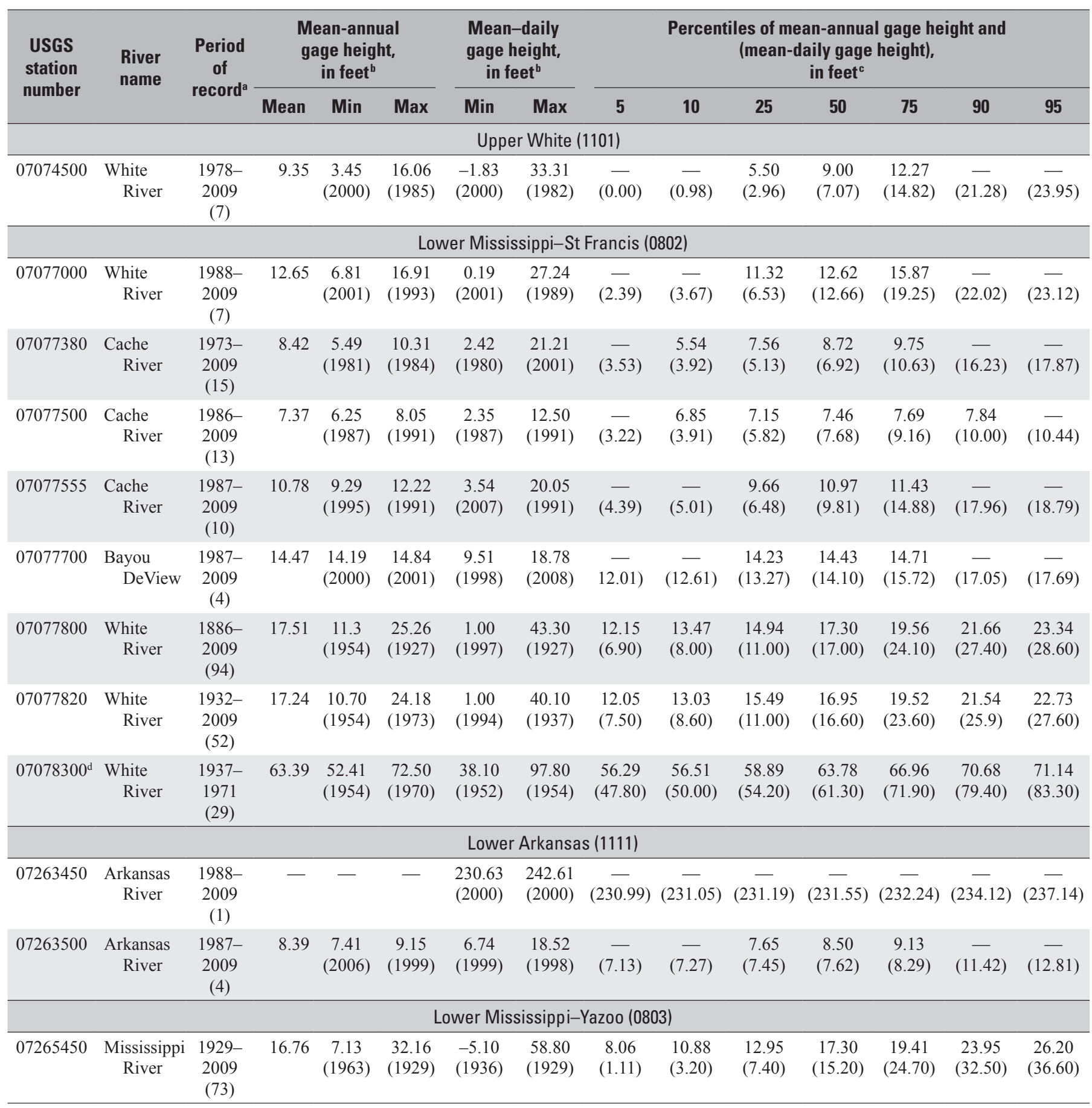

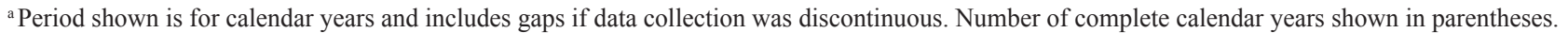

${ }^{\mathrm{b}}$ Statistics listed for mean-annual and mean-daily gage height are based on complete calendar years. Year of minimum and maximum values for meanannual and mean-daily gage-height numbers shown in parentheses.
}

${ }^{\mathrm{c}}$ Percentiles listed for mean-annual and mean-daily gage height are based on complete calendar years.

${ }^{\mathrm{d}}$ Inactive station. 
Table 7A. Summary descriptive statistics and percentiles for discharge by water year for gaging stations in the contributing watersheds of the Cache and White River National Wildlife Refuges and vicinity, Arkansas, Missouri, and Oklahoma.

[Major drainage boundaries and locations of U.S. Geological Survey (USGS) gaging stations shown in figure 1; USGS hydrologic subregions, and subregion hydrologic-unit codes, listed as subheadings and also shown in figure $1 ; \mathrm{mi}^{2}$, square mile; $\mathrm{ft}^{3} \mathrm{~s}^{-1}$, cubic feet per second; Min, minimum value; Max, maximum value; - , too few values to compute the indicated percentile; water year, October 1, preceding calendar year, through September 30, current calendar year]

\begin{tabular}{|c|c|c|c|c|c|c|c|c|c|c|c|c|c|c|}
\hline $\begin{array}{l}\text { USGS } \\
\text { station } \\
\text { number }\end{array}$ & $\begin{array}{l}\text { River } \\
\text { name }\end{array}$ & $\begin{array}{l}\text { Period } \\
\text { of } \\
\text { record }^{a}\end{array}$ & \multicolumn{3}{|c|}{$\begin{array}{l}\text { Mean-annual } \\
\text { discharge, } \\
\text { in } \mathrm{ft}^{3} \mathrm{~s}^{-1}\end{array}$} & \multicolumn{2}{|c|}{$\begin{array}{l}\text { Mean-daily } \\
\text { discharge, } \\
\text { in } \mathrm{ft}^{3} \mathrm{~s}^{-1}\end{array}$} & \multicolumn{7}{|c|}{$\begin{array}{l}\text { Percentiles of mean-annual discharge and } \\
\text { (mean-daily discharge),e } \\
\text { in } \mathrm{ft}^{3} \mathrm{~s}^{-1}\end{array}$} \\
\hline \multicolumn{15}{|c|}{ Upper White (1101) } \\
\hline 07074500 & $\begin{array}{l}\text { White } \\
\text { River }\end{array}$ & $\begin{array}{c}1928- \\
2009 \\
(75) \\
\end{array}$ & $\begin{array}{c}22,600 \\
(1.14)\end{array}$ & $\begin{array}{c}8,070 \\
(1981)\end{array}$ & $\begin{array}{l}46,300 \\
(1945)\end{array}$ & $\begin{array}{c}2,870 \\
(1954)\end{array}$ & $\begin{array}{c}340,000 \\
(1945)\end{array}$ & $\begin{array}{l}10,600 \\
(5,200)\end{array}$ & $\begin{array}{l}11,400 \\
(6,280)\end{array}$ & $\begin{array}{l}14,500 \\
(9,000)\end{array}$ & $\begin{array}{c}21,600 \\
(15,300)\end{array}$ & $\begin{array}{c}28,400 \\
(29,000)\end{array}$ & $\begin{array}{c}34,200 \\
(48,200)\end{array}$ & $\begin{array}{c}41,300 \\
(59,200)\end{array}$ \\
\hline \multicolumn{15}{|c|}{ Lower Mississippi-St Francis (0802) } \\
\hline 07047970 & $\begin{array}{l}\text { Mississippi } \\
\text { River }\end{array}$ & $\begin{array}{l}1928- \\
1977 \\
(49)\end{array}$ & $\begin{array}{c}481,000 \\
(0.51)\end{array}$ & $\begin{array}{c}241,000 \\
(1931)\end{array}$ & $\begin{array}{c}814,000 \\
(1973)\end{array}$ & $\begin{array}{l}48,000 \\
(1972)\end{array}$ & $\begin{array}{c}1,960,000 \\
(1937)\end{array}$ & $\begin{array}{c}258,000 \\
(139,000)\end{array}$ & $\begin{array}{c}286,000 \\
(168,000)\end{array}$ & $\begin{array}{c}397,000 \\
(234,000)\end{array}$ & $\begin{array}{c}469,000 \\
(376,000)\end{array}$ & $\begin{array}{c}549,000 \\
(653,000)\end{array}$ & $\begin{array}{c}672,000 \\
(952,000)\end{array}$ & $\begin{array}{c}711,000 \\
(1,120,000)\end{array}$ \\
\hline 07077380 & $\begin{array}{l}\text { Cache } \\
\text { River }\end{array}$ & $\begin{array}{c}1965- \\
2009 \\
(44)\end{array}$ & $\begin{array}{c}857 \\
(1.22)\end{array}$ & $\begin{array}{c}300 \\
(1972)\end{array}$ & $\begin{array}{c}1,760 \\
(1973)\end{array}$ & $\begin{array}{c}0 \\
(1983)\end{array}$ & $\begin{array}{c}7,940 \\
(1973)\end{array}$ & $\begin{array}{l}354 \\
(18)\end{array}$ & $\begin{array}{l}400 \\
(35)\end{array}$ & $\begin{array}{l}631 \\
(94)\end{array}$ & $\begin{array}{c}823 \\
(290)\end{array}$ & $\begin{array}{c}1,090 \\
(1,130)\end{array}$ & $\begin{array}{c}1,350 \\
(2,790)\end{array}$ & $\begin{array}{c}1,600 \\
(3,500)\end{array}$ \\
\hline 07077500 & $\begin{array}{l}\text { Cache } \\
\text { River }\end{array}$ & $\begin{array}{c}1928- \\
2009 \\
(60)\end{array}$ & $\begin{array}{l}1,230 \\
(1.18)\end{array}$ & $\begin{array}{c}308 \\
(1931)\end{array}$ & $\begin{array}{c}2,980 \\
(1950)\end{array}$ & $\begin{array}{c}0 \\
(1957)\end{array}$ & $\begin{array}{l}12,100 \\
(1928)\end{array}$ & $\begin{array}{l}400 \\
(46)\end{array}$ & $\begin{array}{l}462 \\
(66)\end{array}$ & $\begin{array}{c}720 \\
(156)\end{array}$ & $\begin{array}{l}1,170 \\
(450)\end{array}$ & $\begin{array}{c}1,550 \\
(1,730)\end{array}$ & $\begin{array}{c}2,080 \\
(3,590)\end{array}$ & $\begin{array}{c}2,510 \\
(4,680)\end{array}$ \\
\hline 07077555 & $\begin{array}{l}\text { Cache } \\
\text { River }\end{array}$ & $\begin{array}{c}1987- \\
2009 \\
(21)\end{array}$ & $\begin{array}{l}1,350 \\
(1.15)\end{array}$ & $\begin{array}{c}422 \\
(2006)\end{array}$ & $\begin{array}{c}2,360 \\
(1989)\end{array}$ & $\begin{array}{c}7.8 \\
(2001)\end{array}$ & $\begin{array}{c}9,770 \\
(1988)\end{array}$ & $\begin{array}{l}560 \\
(54)\end{array}$ & $\begin{array}{c}699 \\
(114)\end{array}$ & $\begin{array}{c}998 \\
(295)\end{array}$ & $\begin{array}{l}1,330 \\
(771)\end{array}$ & $\begin{array}{c}1,740 \\
(1,880)\end{array}$ & $\begin{array}{c}1,950 \\
(3,380)\end{array}$ & $\begin{array}{c}2,120 \\
(4,590)\end{array}$ \\
\hline $07077952^{\mathrm{f}}$ & Big Creek & $\begin{array}{l}1971- \\
1972 \\
(2)\end{array}$ & $\begin{array}{c}259 \\
(0.56)\end{array}$ & $\begin{array}{c}157 \\
(1972)\end{array}$ & $\begin{array}{c}360 \\
(1971)\end{array}$ & $\begin{array}{c}0 \\
(1972)\end{array}$ & $\begin{array}{c}1,130 \\
(1971)\end{array}$ & $-\overline{(2.1)}$ & $-\overline{(8.2)}$ & - & $\begin{array}{c}259 \\
(141)\end{array}$ & $(381)$ & - & - \\
\hline $07078000^{\mathrm{f}}$ & $\begin{array}{l}\text { LaGrue } \\
\text { Bayou }\end{array}$ & $\begin{array}{c}1936- \\
1954 \\
(19)\end{array}$ & $\begin{array}{c}226 \\
(1.29)\end{array}$ & $\begin{array}{c}54 \\
(1936)\end{array}$ & $\begin{array}{c}489 \\
(1950)\end{array}$ & $\begin{array}{c}0 \\
(1936)\end{array}$ & $\begin{array}{c}6,440 \\
(1937)\end{array}$ & $\overline{(0.2)}$ & $\begin{array}{c}86 \\
(1.1)\end{array}$ & $\begin{array}{c}107 \\
(7.2)\end{array}$ & $\begin{array}{l}204 \\
(37)\end{array}$ & $\begin{array}{c}306 \\
(228)\end{array}$ & $\begin{array}{c}455 \\
(627)\end{array}$ & $(\overline{-}, 070)$ \\
\hline 07264000 & $\begin{array}{l}\text { Bayou } \\
\text { Meto }\end{array}$ & $\begin{array}{c}1955- \\
2009 \\
(54)\end{array}$ & $\begin{array}{c}287 \\
(1.39)\end{array}$ & $\begin{array}{c}95 \\
(1963)\end{array}$ & $\begin{array}{c}550 \\
(1973)\end{array}$ & $\begin{array}{c}0 \\
(1955)\end{array}$ & $\begin{array}{c}5,570 \\
(1988)\end{array}$ & $\begin{array}{c}118 \\
(2.0)\end{array}$ & $\begin{array}{c}155 \\
(5.6)\end{array}$ & $\begin{array}{l}211 \\
(18)\end{array}$ & $\begin{array}{l}266 \\
(85)\end{array}$ & $\begin{array}{c}363 \\
(352)\end{array}$ & $\begin{array}{c}451 \\
(865)\end{array}$ & $\begin{array}{c}485 \\
(1,230)\end{array}$ \\
\hline
\end{tabular}


Table 7A. Summary descriptive statistics and percentiles for discharge by water year for gaging stations in the contributing watersheds of the Cache and White River National Wildlife Refuges and vicinity, Arkansas, Missouri, and Oklahoma.-Continued

[Major drainage boundaries and locations of U.S. Geological Survey (USGS) gaging stations shown in figure 1; USGS hydrologic subregions, and subregion hydrologic-unit codes, listed as subheadings and also shown in figure $1 ; \mathrm{mi}^{2}$, square mile; $\mathrm{ft}^{3} \mathrm{~s}^{-1}$, cubic feet per second; Min, minimum value; Max, maximum value; - , too few values to compute the indicated percentile; water year, October 1, preceding calendar year, through September 30, current calendar year]

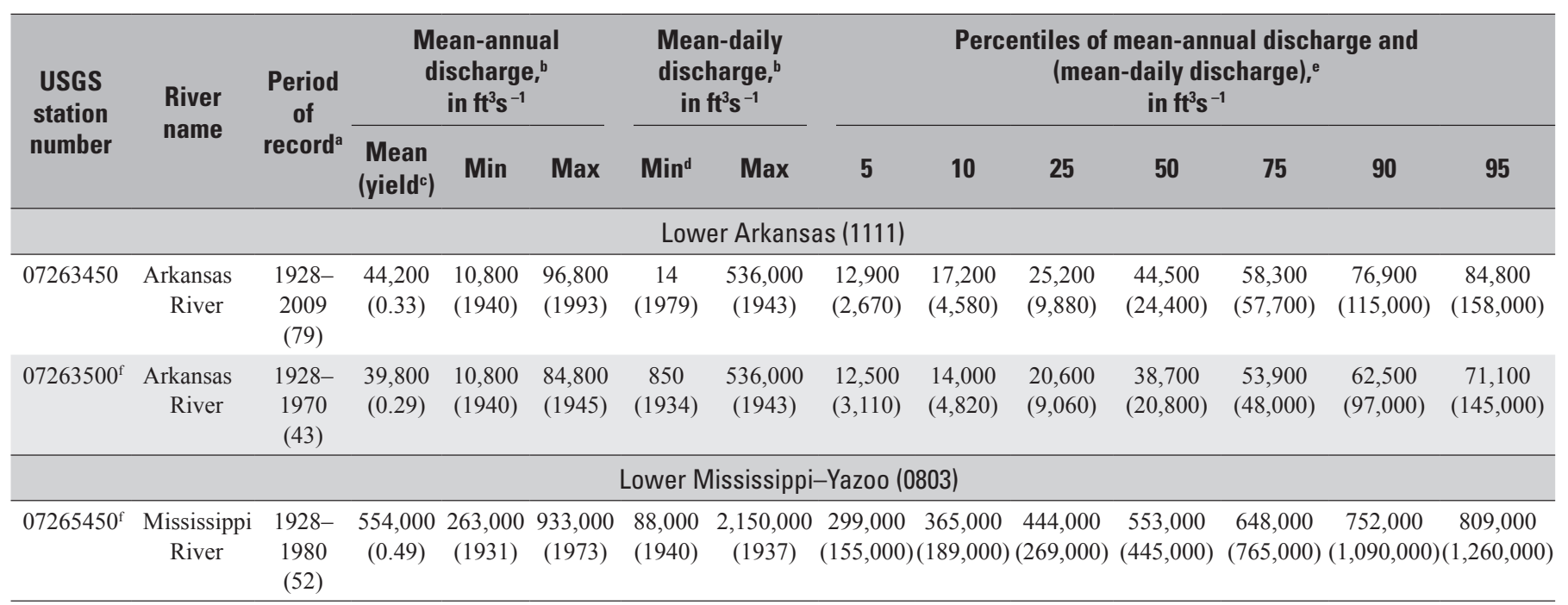

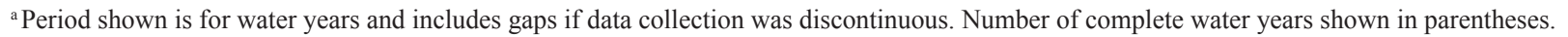

${ }^{\mathrm{b}}$ Statistics listed for mean-annual and mean-daily discharge are based on complete water years. Year of minimum and maximum values for mean-annual and mean-daily discharge numbers shown in parentheses.

${ }^{c}$ Yield units are cubic feet per second per square mile. Yields are based on contributing drainage areas where given.

${ }^{\mathrm{d}}$ Mean daily discharge of zero first occurred during the water year indicated but may subsequently have occurred in one or more years.

${ }^{\text {e }}$ Percentiles listed for mean-annual and mean-daily discharge are based on complete water years.

${ }^{\mathrm{f}}$ Inactive station. 
Table 7B. Summary descriptive statistics and percentiles for discharge by calendar year for gaging stations in the contributing watersheds of the Cache and White River National Wildlife Refuges and vicinity, Arkansas, Missouri, and Oklahoma.

[Major drainage boundaries and locations of U.S. Geological Survey (USGS) gaging stations shown in figure 1; USGS hydrologic subregions, and subregion hydrologic-unit codes, listed as subheadings and also shown in figure $1 ; \mathrm{mi}^{2}$, square mile; $\mathrm{ft}^{3} \mathrm{~s}^{-1}$, cubic feet per second; Min, minimum value; Max, maximum value; - , too few values to compute the indicated percentile; calendar year, January 1 through December 31]

\begin{tabular}{|c|c|c|c|c|c|c|c|c|c|c|c|c|c|c|}
\hline $\begin{array}{l}\text { USGS } \\
\text { station } \\
\text { number }\end{array}$ & $\begin{array}{l}\text { River } \\
\text { name }\end{array}$ & $\begin{array}{l}\text { Period } \\
\text { of } \\
\text { recorda }\end{array}$ & \multicolumn{3}{|c|}{$\begin{array}{l}\text { Mean-annual } \\
\text { discharge, } \\
\text { in } \mathrm{ft}^{3} \mathrm{~s}^{-1}\end{array}$} & \multicolumn{2}{|c|}{$\begin{array}{l}\text { Mean-daily } \\
\text { discharge, } \\
\text { in } \mathrm{ft}^{3} \mathrm{~s}^{-1}\end{array}$} & \multicolumn{7}{|c|}{$\begin{array}{l}\text { Percentiles of mean-annual discharge and } \\
\text { (mean-daily discharge), } \\
\text { in } \mathrm{ft}^{3} \mathrm{~s}^{-1}\end{array}$} \\
\hline \multicolumn{15}{|c|}{ Upper White (1101) } \\
\hline \multicolumn{15}{|c|}{ Lower Mississippi-St Francis (0802) } \\
\hline 07047970 & $\begin{array}{l}\text { Mississippi } \\
\text { River }\end{array}$ & $\begin{array}{c}1928- \\
1977 \\
(49)\end{array}$ & $\begin{array}{c}486,000 \\
(0.52)\end{array}$ & $\begin{array}{c}268,000 \\
(1934)\end{array}$ & $\begin{array}{c}780,000 \\
(1973)\end{array}$ & $\begin{array}{l}48,000 \\
(1971)\end{array}$ & $\begin{array}{c}1,960,000 \\
(1937)\end{array}$ & $\begin{array}{c}297,000 \\
(139,000)\end{array}$ & $\begin{array}{c}307,000 \\
(168,000)\end{array}$ & $\begin{array}{c}395,000 \\
(236,000)\end{array}$ & $\begin{array}{c}486,000 \\
(384,000)\end{array}$ & $\begin{array}{c}541,000 \\
(661,000)\end{array}$ & $\begin{array}{c}677,000 \\
(957,000)\end{array}$ & $\begin{array}{r}704,000 \\
1,120,000\end{array}$ \\
\hline 07077380 & $\begin{array}{l}\text { Cache } \\
\text { River }\end{array}$ & $\begin{array}{c}1964- \\
2009 \\
(44)\end{array}$ & $\begin{array}{c}854 \\
(1.22)\end{array}$ & $\begin{array}{c}326 \\
(1980)\end{array}$ & $\begin{array}{c}1,690 \\
(1973)\end{array}$ & $\begin{array}{c}0 \\
(1982)\end{array}$ & $\begin{array}{c}7,940 \\
(1973)\end{array}$ & $\begin{array}{l}361 \\
(18)\end{array}$ & $\begin{array}{l}545 \\
(34)\end{array}$ & $\begin{array}{l}685 \\
(93)\end{array}$ & $\begin{array}{c}811 \\
(287)\end{array}$ & $\begin{array}{c}1,060 \\
(1,120)\end{array}$ & $\begin{array}{c}1,140 \\
(2,790)\end{array}$ & $\begin{array}{c}1,360 \\
(3,500)\end{array}$ \\
\hline 07077500 & $\begin{array}{l}\text { Cache } \\
\text { River }\end{array}$ & $\begin{array}{c}1927- \\
2009 \\
(59)\end{array}$ & $\begin{array}{l}1,240 \\
(1.19)\end{array}$ & $\begin{array}{c}376 \\
(1941)\end{array}$ & $\begin{array}{l}2,780 \\
(1950)\end{array}$ & $\begin{array}{c}0 \\
(1956)\end{array}$ & $\begin{array}{l}12,100 \\
(1928)\end{array}$ & $\begin{array}{l}529 \\
(42)\end{array}$ & $\begin{array}{l}656 \\
(63)\end{array}$ & $\begin{array}{c}828 \\
(156)\end{array}$ & $\begin{array}{l}1,180 \\
(458)\end{array}$ & $\begin{array}{c}1,410 \\
(1,740)\end{array}$ & $\begin{array}{c}2,250 \\
(3,590)\end{array}$ & $\begin{array}{c}2,400 \\
(4,760)\end{array}$ \\
\hline 07077555 & $\begin{array}{l}\text { Cache } \\
\text { River }\end{array}$ & $\begin{array}{l}1987- \\
2009 \\
(21)\end{array}$ & $\begin{array}{l}1,340 \\
(1.15)\end{array}$ & $\begin{array}{c}807 \\
(2000)\end{array}$ & $\begin{array}{l}2,040 \\
(1991)\end{array}$ & $\begin{array}{c}7.8 \\
(2000)\end{array}$ & $\begin{array}{c}9,230 \\
(1997)\end{array}$ & $\begin{array}{l}876 \\
(53)\end{array}$ & $\begin{array}{c}889 \\
(113)\end{array}$ & $\begin{array}{c}988 \\
(291)\end{array}$ & $\begin{array}{l}1,430 \\
(760)\end{array}$ & $\begin{array}{c}1,530 \\
(1,870)\end{array}$ & $\begin{array}{c}1,700 \\
(3,370)\end{array}$ & $\begin{array}{c}1,730 \\
(4,560)\end{array}$ \\
\hline $07077952^{\mathrm{f}}$ & Big Creek & $\begin{array}{c}1970- \\
1972 \\
(1)\end{array}$ & $\begin{array}{c}330 \\
(0.72)\end{array}$ & $\begin{array}{c}330 \\
(1971)\end{array}$ & $\begin{array}{c}330 \\
(1971)\end{array}$ & $\begin{array}{c}1.3 \\
(1971)\end{array}$ & $\begin{array}{c}1,130 \\
(1971)\end{array}$ & $\overline{(2.0)}$ & - & $\frac{-}{(52)}$ & $\overline{(188)}$ & $\overline{(598)}$ & $\overline{(813)}$ & (928) \\
\hline $07078000^{\mathrm{f}}$ & $\begin{array}{l}\text { LaGrue } \\
\text { Bayou }\end{array}$ & $\begin{array}{c}1935- \\
1954 \\
(18)\end{array}$ & $\begin{array}{c}232 \\
(1.33)\end{array}$ & $\begin{array}{c}63 \\
(1936)\end{array}$ & $\begin{array}{c}456 \\
(1945)\end{array}$ & $\begin{array}{c}0 \\
(1936)\end{array}$ & $\begin{array}{c}6,440 \\
(1937)\end{array}$ & $\overline{(0.3)}$ & $\begin{array}{c}74 \\
(1.5)\end{array}$ & $\begin{array}{c}123 \\
(8.0)\end{array}$ & $\begin{array}{l}244 \\
(40)\end{array}$ & $\begin{array}{c}311 \\
(240)\end{array}$ & $\begin{array}{c}414 \\
(635)\end{array}$ & $\begin{array}{c}456 \\
(1,070)\end{array}$ \\
\hline 07264000 & $\begin{array}{l}\text { Bayou } \\
\text { Meto }\end{array}$ & $\begin{array}{c}1954- \\
2009 \\
(54)\end{array}$ & $\begin{array}{c}288 \\
(1.39)\end{array}$ & $\begin{array}{c}96 \\
(1963)\end{array}$ & $\begin{array}{c}633 \\
(1957)\end{array}$ & $\begin{array}{c}0 \\
(1955)\end{array}$ & $\begin{array}{c}5,570 \\
(1987)\end{array}$ & $\begin{array}{l}155 \\
(2.3)\end{array}$ & $\begin{array}{c}173 \\
(5.9)\end{array}$ & $\begin{array}{l}206 \\
(18)\end{array}$ & $\begin{array}{l}273 \\
(87)\end{array}$ & $\begin{array}{c}343 \\
(352)\end{array}$ & $\begin{array}{c}433 \\
(865)\end{array}$ & $\begin{array}{c}458 \\
(1,230)\end{array}$ \\
\hline
\end{tabular}


Table 7B. Summary descriptive statistics and percentiles for discharge by calendar year for gaging stations in the contributing watersheds of the Cache and White River National Wildlife Refuges and vicinity, Arkansas, Missouri, and Oklahoma.-Continued

[Major drainage boundaries and locations of U.S. Geological Survey (USGS) gaging stations shown in figure 1; USGS hydrologic subregions, and subregion hydrologic-unit codes, listed as subheadings and also shown in figure $1 ; \mathrm{mi}^{2}$, square mile; $\mathrm{ft}^{3} \mathrm{~s}^{-1}$, cubic feet per second; Min, minimum value; Max, maximum value; - , too few values to compute the indicated percentile; calendar year, January 1 through December 31]

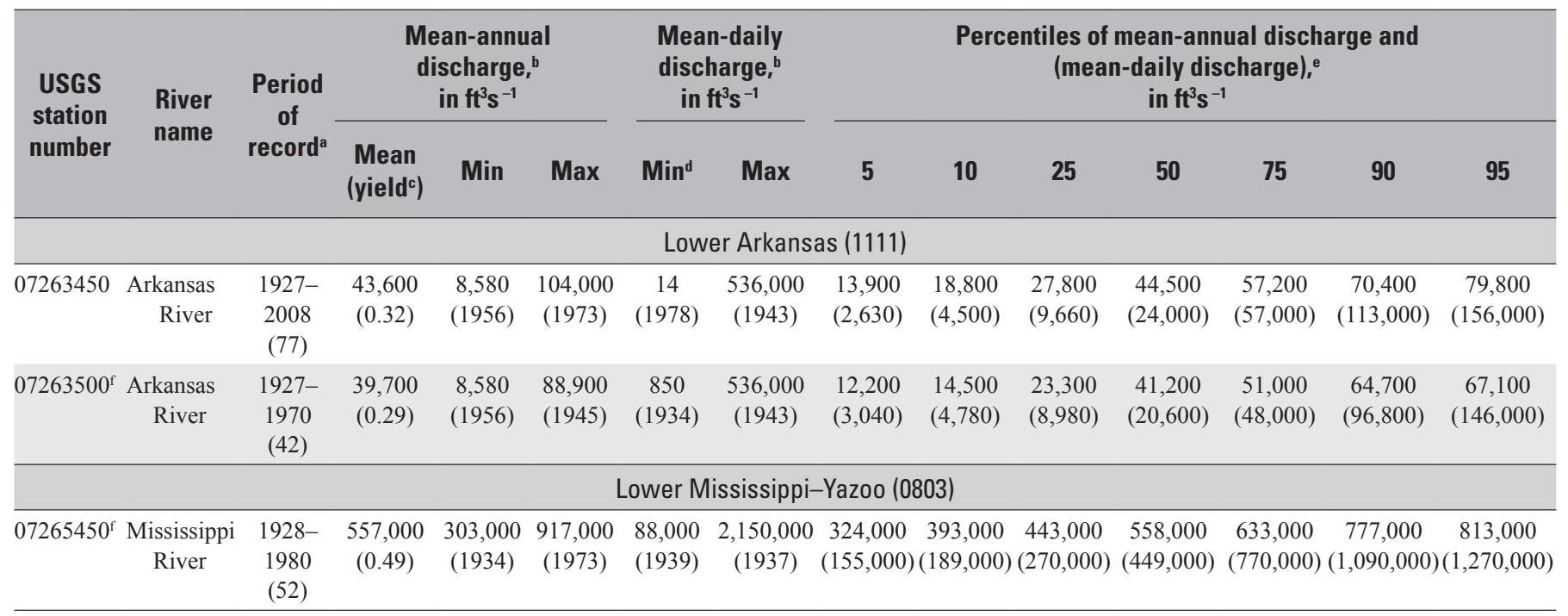

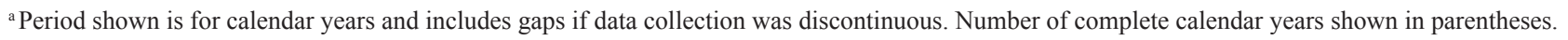

${ }^{\mathrm{b}}$ Statistics listed for mean-annual and mean-daily discharge are based on complete calendar years. Year of minimum and maximum values for mean-annual and mean-daily discharge numbers shown in parentheses.

${ }^{c}$ Yield units are cfsm, cubic feet per second per square mile. Yields are based on contributing drainage areas where given.

${ }^{\mathrm{d}}$ Mean daily discharge of zero first occurred during the calendar year indicated but may subsequently have occurred in one or more years.

${ }^{e}$ Percentiles listed for mean-annual and mean-daily discharge are based on complete calendar years.

${ }^{\mathrm{f}}$ Inactive station. 
Table 8A. Selected hydrologic metrics for gage height by water year for gaging stations in the contributing watersheds of the Cache and White River National Wildlife Refuges and vicinity, Arkansas, Missouri, and Oklahoma.

[Major drainage boundaries and locations of U.S. Geological Survey (USGS) gaging stations shown in figure 1; USGS hydrologic subregions, and subregion hydrologic-unit codes, listed as subheadings and also shown in figure 1; water year, October 1, preceding calendar year, through September 30 , current calendar year; all values unitless unless stated otherwise; LCV5, coefficient of variation of the set of every 5th percentile of $\log _{10}$ discharge; RBFI, RichardsBaker flashiness index (Baker and others, 2004); median and mean values of hydrologic metrics by water year are given for each metric (mean values in parentheses); - , too few annual values to compute the indicated metric]

\begin{tabular}{|c|c|c|c|c|c|c|c|c|c|c|c|c|c|c|c|}
\hline \multirow{2}{*}{$\begin{array}{c}\text { USGS } \\
\text { station } \\
\text { number }\end{array}$} & \multirow{2}{*}{$\begin{array}{l}\text { River } \\
\text { name }\end{array}$} & \multirow{2}{*}{$\begin{array}{c}\text { Period } \\
\text { of } \\
\text { record }^{a}\end{array}$} & \multirow{2}{*}{ LCV5 } & \multicolumn{3}{|c|}{$\begin{array}{c}\text { Percentile } \\
\text { spread measures }^{b}\end{array}$} & \multicolumn{3}{|c|}{$\begin{array}{c}\text { Percentile } \\
\text { ratio measures }^{c}\end{array}$} & \multicolumn{3}{|c|}{$\begin{array}{l}\text { Magnitude } \\
\text { metrics }^{\mathrm{d}}\end{array}$} & \multicolumn{2}{|c|}{$\begin{array}{l}\text { Duration metrics, } \\
\text { in days }^{\mathrm{d}}\end{array}$} & \multirow{2}{*}{ RBFI } \\
\hline & & & & 7525 & 8020 & 9010 & 7525 & 8020 & 9010 & $\begin{array}{c}\text { Cum } \\
50\end{array}$ & $\begin{array}{c}\text { Rise } \\
50 \\
\end{array}$ & $\begin{array}{r}\text { Fall } \\
50 \\
\end{array}$ & $\begin{array}{c}\text { Risedur } \\
50 \\
\end{array}$ & $\begin{array}{c}\text { Falldur } \\
50\end{array}$ & \\
\hline \multicolumn{16}{|c|}{ Upper White (1101) } \\
\hline 07074500 & $\begin{array}{l}\text { White } \\
\text { River }\end{array}$ & $\begin{array}{l}1978- \\
2009\end{array}$ & $\begin{array}{c}43.8 \\
(46.8)\end{array}$ & $\begin{array}{c}1.31 \\
(1.28)\end{array}$ & $\begin{array}{c}1.59 \\
(1.59)\end{array}$ & $\begin{array}{l}2.08 \\
(2.31)\end{array}$ & $\begin{array}{c}3.76 \\
(3.69)\end{array}$ & $\begin{array}{c}5.62 \\
(5.29)\end{array}$ & $\begin{array}{l}29.2 \\
(128)\end{array}$ & $\begin{array}{c}34.1 \\
(47.0)\end{array}$ & $\begin{array}{c}1.22 \\
(1.23)\end{array}$ & $\begin{array}{c}1.30 \\
(1.29)\end{array}$ & $\begin{array}{l}2.00 \\
(2.14)\end{array}$ & $\begin{array}{l}3.00 \\
(2.57)\end{array}$ & $\begin{array}{c}0.08 \\
(0.10)\end{array}$ \\
\hline
\end{tabular}

\begin{tabular}{|c|c|c|c|c|c|c|c|c|c|c|c|c|c|c|c|}
\hline \multicolumn{16}{|c|}{ Lower Mississippi-St Francis (0802) } \\
\hline 07077380 & $\begin{array}{l}\text { Cache } \\
\text { River }\end{array}$ & $\begin{array}{c}1974 \\
2009 \\
(14)\end{array}$ & $\begin{array}{c}21.8 \\
(22.0)\end{array}$ & $\begin{array}{c}0.76 \\
(0.76)\end{array}$ & $\begin{array}{c}0.97 \\
(0.99)\end{array}$ & $\begin{array}{c}1.49 \\
(1.53)\end{array}$ & $\begin{array}{c}2.04 \\
(2.03)\end{array}$ & $\begin{array}{c}2.37 \\
(2.39)\end{array}$ & $\begin{array}{c}3.20 \\
(3.49)\end{array}$ & $\begin{array}{c}35.4 \\
(36.1)\end{array}$ & $\begin{array}{c}1.62 \\
(1.60)\end{array}$ & $\begin{array}{c}1.56 \\
(1.51)\end{array}$ & $\begin{array}{c}2.00 \\
(2.29)\end{array}$ & $\begin{array}{c}4.00 \\
(4.25)\end{array}$ & $\begin{array}{c}0.08 \\
(0.08)\end{array}$ \\
\hline 07077555 & $\begin{array}{l}\text { Cache } \\
\text { River }\end{array}$ & $\begin{array}{c}1987- \\
2009 \\
(12)\end{array}$ & $\begin{array}{c}19.3 \\
(20.2)\end{array}$ & $\begin{array}{c}0.78 \\
(0.83)\end{array}$ & $\begin{array}{c}0.90 \\
(0.97)\end{array}$ & $\begin{array}{c}1.22 \\
(1.28)\end{array}$ & $\begin{array}{c}2.10 \\
(2.27)\end{array}$ & $\begin{array}{c}2.43 \\
(2.60)\end{array}$ & $\begin{array}{c}3.37 \\
(3.44)\end{array}$ & $\begin{array}{c}12.9 \\
(12.3)\end{array}$ & $\begin{array}{c}1.41 \\
(1.82)\end{array}$ & $\begin{array}{c}1.10 \\
(1.40)\end{array}$ & $\begin{array}{c}5.75 \\
(6.08)\end{array}$ & $\begin{array}{c}6.50 \\
(6.54)\end{array}$ & $\begin{array}{c}0.03 \\
(0.03)\end{array}$ \\
\hline 07077700 & $\begin{array}{l}\text { Bayou } \\
\text { DeView }\end{array}$ & $\begin{array}{c}1987- \\
2009 \\
(5)\end{array}$ & $\begin{array}{c}3.70 \\
(3.90)\end{array}$ & $\begin{array}{c}0.16 \\
(0.17)\end{array}$ & $\begin{array}{c}0.20 \\
(0.20)\end{array}$ & $\begin{array}{c}0.29 \\
(0.29)\end{array}$ & $\begin{array}{c}1.17 \\
(1.18)\end{array}$ & $\begin{array}{c}1.21 \\
(1.22)\end{array}$ & $\begin{array}{c}1.32 \\
(1.34)\end{array}$ & $\begin{array}{c}6.43 \\
(6.32)\end{array}$ & $\begin{array}{c}0.77 \\
(0.85)\end{array}$ & $\begin{array}{c}0.96 \\
(0.97)\end{array}$ & $\begin{array}{c}3.00 \\
(3.20)\end{array}$ & $\begin{array}{c}5.50 \\
(5.50)\end{array}$ & $\begin{array}{c}0.02 \\
(0.02)\end{array}$ \\
\hline 07077820 & $\begin{array}{l}\text { White } \\
\text { River }\end{array}$ & $\begin{array}{c}1932- \\
2009 \\
(44)\end{array}$ & $\begin{array}{c}12.1 \\
(13.3)\end{array}$ & $\begin{array}{c}0.56 \\
(0.62)\end{array}$ & $\begin{array}{c}0.66 \\
(0.73)\end{array}$ & $\begin{array}{c}0.93 \\
(1.00)\end{array}$ & $\begin{array}{c}1.77 \\
(1.90)\end{array}$ & $\begin{array}{c}1.97 \\
(2.14)\end{array}$ & $\begin{array}{c}2.53 \\
(2.81)\end{array}$ & $\begin{array}{c}6.07 \\
(6.60)\end{array}$ & $\begin{array}{c}0.58 \\
(0.79)\end{array}$ & $\begin{array}{c}0.45 \\
(0.68)\end{array}$ & $\begin{array}{c}3.00 \\
(3.10)\end{array}$ & $\begin{array}{c}3.00 \\
(3.00)\end{array}$ & $\begin{array}{c}0.02 \\
(0.02)\end{array}$ \\
\hline $07078300^{\mathrm{e}}$ & $\begin{array}{l}\text { White } \\
\text { River }\end{array}$ & $\begin{array}{c}1938- \\
1971 \\
(32)\end{array}$ & $\begin{array}{c}3.47 \\
(3.54)\end{array}$ & $\begin{array}{c}0.24 \\
(0.25)\end{array}$ & $\begin{array}{c}0.29 \\
(0.31)\end{array}$ & $\begin{array}{c}0.41 \\
(0.43)\end{array}$ & $\begin{array}{c}1.27 \\
(1.28)\end{array}$ & $\begin{array}{c}1.34 \\
(1.35)\end{array}$ & $\begin{array}{c}1.49 \\
(1.51)\end{array}$ & $\begin{array}{c}2.93 \\
(2.93)\end{array}$ & $\begin{array}{c}1.04 \\
(1.15)\end{array}$ & $\begin{array}{c}1.00 \\
(1.13)\end{array}$ & $\begin{array}{c}3.00 \\
(3.47)\end{array}$ & $\begin{array}{c}4.00 \\
(3.98)\end{array}$ & $\begin{array}{c}0.01 \\
(0.01)\end{array}$ \\
\hline \multicolumn{16}{|c|}{ Lower Arkansas (1111) } \\
\hline 07263450 & $\begin{array}{c}\text { Arkansas } \\
\text { River }\end{array}$ & $\begin{array}{c}1989- \\
2009 \\
(1)\end{array}$ & - & - & - & - & - & - & - & - & - & - & - & - & - \\
\hline
\end{tabular}

\footnotetext{
${ }^{\text {a }}$ Period shown is for water years and includes gaps if data collection was discontinuous. Number of complete water years shown in parentheses.

${ }^{\mathrm{b}}$ Percentile spread measures are calculated as the difference between the indicated percentiles divided by the median where 7525 $=(\mathrm{p} 75-\mathrm{p} 25) / \mathrm{p} 50$, $8020=(\mathrm{p} 80-\mathrm{p} 20) / \mathrm{p} 50$, and $9010=(\mathrm{p} 90-\mathrm{p} 10) / \mathrm{p} 50$.

${ }^{\mathrm{c}}$ Percentile ratio measures are calculated as the ratios of the indicated percentiles where $7525=\mathrm{p} 75 / \mathrm{p} 25,8020=\mathrm{p} 80 / \mathrm{p} 20$, and $9010=\mathrm{p} 90 / \mathrm{p} 10$.

${ }^{\mathrm{d}}$ Magnitude and duration metrics (McMahon and others, 2003): Cum_50, sum incremental change, absolute value gage height, normalized to the median incremental change, absolute value gage height; Rise_50, median rise in gage height, in feet; Fall_50, median fall in gage height, in feet; Risedur_50, median rise duration, in days; Falldur_50, median fall duration, in days.

${ }^{\mathrm{e}}$ Inactive station.
} 
Table 8B. Selected hydrologic metrics for gage height by calendar year for gaging stations in the contributing watersheds of the Cache and White River National Wildlife Refuges and vicinity, Arkansas, Missouri, and Oklahoma.

[Major drainage boundaries and locations of U.S. Geological Survey (USGS) gaging stations shown in figure 1; USGS hydrologic subregions, and subregion hydrologic-unit codes, listed as subheadings and also shown in figure 1; water year, October 1, preceding calendar year, through September 30, current calendar year; all values unitless unless stated otherwise; LCV5, coefficient of variation of the set of every 5 th percentile of $\log _{10}$ discharge; RBFI, RichardsBaker flashiness index (Baker and others, 2004); median and mean values of hydrologic metrics by water year are given for each metric (mean values in parentheses); - , too few annual values to compute the indicated metric]

\begin{tabular}{|c|c|c|c|c|c|c|c|c|c|c|c|c|c|c|c|}
\hline \multirow{2}{*}{$\begin{array}{c}\text { USGS } \\
\text { station } \\
\text { number }\end{array}$} & \multirow{2}{*}{$\begin{array}{l}\text { River } \\
\text { name }\end{array}$} & \multirow{2}{*}{$\begin{array}{c}\text { Period } \\
\text { of } \\
\text { record }^{a}\end{array}$} & \multirow{2}{*}{ LCV5 } & \multicolumn{3}{|c|}{$\begin{array}{c}\text { Percentile } \\
\text { spread measures }^{b}\end{array}$} & \multicolumn{3}{|c|}{$\begin{array}{c}\text { Percentile } \\
\text { ratio measures }^{\mathrm{c}}\end{array}$} & \multicolumn{3}{|c|}{$\begin{array}{l}\text { Magnitude } \\
\text { metrics }^{\mathrm{d}}\end{array}$} & \multicolumn{2}{|c|}{$\begin{array}{c}\text { Duration metrics, } \\
\text { in days }{ }^{d}\end{array}$} & \multirow{2}{*}{ RBFI } \\
\hline & & & & 7525 & 8020 & 9010 & 7525 & 8020 & 9010 & $\begin{array}{c}\text { Cum } \\
-50\end{array}$ & $\begin{array}{r}\text { Rise } \\
50 \\
\end{array}$ & $\begin{array}{r}\text { Fall } \\
-50 \\
\end{array}$ & $\begin{array}{c}\text { Risedur } \\
\quad 50 \\
\end{array}$ & $\begin{array}{c}\text { Falldur } \\
\quad 50\end{array}$ & \\
\hline \multicolumn{16}{|c|}{ Upper White (1101) } \\
\hline 07074500 & $\begin{array}{l}\text { White } \\
\text { River }\end{array}$ & $\begin{array}{c}1978- \\
2009 \\
(7)\end{array}$ & $\begin{array}{c}46.4 \\
(48.2)\end{array}$ & $\begin{array}{c}1.43 \\
(1.44)\end{array}$ & $\begin{array}{c}1.67 \\
(1.77)\end{array}$ & $\begin{array}{c}2.20 \\
(2.58)\end{array}$ & $\begin{array}{c}4.36 \\
(4.50)\end{array}$ & $\begin{array}{c}6.35 \\
(8.03)\end{array}$ & $\begin{array}{c}12.0 \\
(16.6)\end{array}$ & $\begin{array}{c}38.2 \\
(48.0)\end{array}$ & $\begin{array}{c}1.33 \\
(1.24)\end{array}$ & $\begin{array}{c}1.37 \\
(1.40)\end{array}$ & $\begin{array}{c}2.00 \\
(2.00)\end{array}$ & $\begin{array}{c}3.00 \\
(2.57)\end{array}$ & $\begin{array}{c}0.09 \\
(0.10)\end{array}$ \\
\hline 07077000 & $\begin{array}{l}\text { White } \\
\text { River }\end{array}$ & $\begin{array}{c}1988- \\
2009 \\
(7)\end{array}$ & $\begin{array}{c}20.6 \\
(26.7)\end{array}$ & $\begin{array}{c}1.01 \\
(0.91)\end{array}$ & $\begin{array}{c}1.12 \\
(1.10)\end{array}$ & $\begin{array}{c}1.50 \\
(1.72)\end{array}$ & $\begin{array}{c}2.40 \\
(2.60)\end{array}$ & $\begin{array}{c}2.64 \\
(3.16)\end{array}$ & $\begin{array}{c}3.66 \\
(5.53)\end{array}$ & $\begin{array}{c}11.0 \\
(13.8)\end{array}$ & $\begin{array}{c}0.77 \\
(0.86)\end{array}$ & $\begin{array}{l}1.08 \\
(1.11)\end{array}$ & $\begin{array}{c}3.00 \\
(3.14)\end{array}$ & $\begin{array}{c}4.00 \\
(4.14)\end{array}$ & $\begin{array}{c}0.03 \\
(0.03)\end{array}$ \\
\hline 07077380 & $\begin{array}{l}\text { Cache } \\
\text { River }\end{array}$ & $\begin{array}{c}1973- \\
2009 \\
(15)\end{array}$ & $\begin{array}{l}21.9 \\
(22.1)\end{array}$ & $\begin{array}{c}0.82 \\
(0.77)\end{array}$ & $\begin{array}{c}1.02 \\
(1.02)\end{array}$ & $\begin{array}{c}1.54 \\
(1.62)\end{array}$ & $\begin{array}{c}2.06 \\
(2.03)\end{array}$ & $\begin{array}{c}2.51 \\
(2.43)\end{array}$ & $\begin{array}{c}3.28 \\
(3.62)\end{array}$ & $\begin{array}{c}35.6 \\
(36.1)\end{array}$ & $\begin{array}{c}1.87 \\
(1.84)\end{array}$ & $\begin{array}{c}1.80 \\
(1.54)\end{array}$ & $\begin{array}{c}2.00 \\
(2.27)\end{array}$ & $\begin{array}{c}4.50 \\
(4.30)\end{array}$ & $\begin{array}{c}0.08 \\
(0.08)\end{array}$ \\
\hline 07077555 & $\begin{array}{l}\text { Cache } \\
\text { River }\end{array}$ & $\begin{array}{c}1987- \\
2009 \\
(10)\end{array}$ & $\begin{array}{c}19.1 \\
(19.8)\end{array}$ & $\begin{array}{c}0.77 \\
(0.83)\end{array}$ & $\begin{array}{c}0.89 \\
(0.96)\end{array}$ & $\begin{array}{c}1.16 \\
(1.21)\end{array}$ & $\begin{array}{c}2.27 \\
(2.29)\end{array}$ & $\begin{array}{c}2.66 \\
(2.64)\end{array}$ & $\begin{array}{c}3.31 \\
(3.38)\end{array}$ & $\begin{array}{c}12.0 \\
(12.8)\end{array}$ & $\begin{array}{c}1.57 \\
(1.83)\end{array}$ & $\begin{array}{c}1.57 \\
(1.98)\end{array}$ & $\begin{array}{c}6.50 \\
(6.45)\end{array}$ & $\begin{array}{c}7.75 \\
(7.55)\end{array}$ & $\begin{array}{c}0.03 \\
(0.03)\end{array}$ \\
\hline 07077700 & $\begin{array}{l}\text { Bayou } \\
\text { DeView }\end{array}$ & $\begin{array}{c}1987- \\
2009 \\
(4)\end{array}$ & $\begin{array}{c}4.23 \\
(4.04)\end{array}$ & $\begin{array}{c}0.17 \\
(0.17)\end{array}$ & $\begin{array}{c}0.22 \\
(0.21)\end{array}$ & $\begin{array}{c}0.32 \\
(0.31)\end{array}$ & $\begin{array}{c}1.18 \\
(1.18)\end{array}$ & $\begin{array}{c}1.24 \\
(1.23)\end{array}$ & $\begin{array}{c}1.37 \\
(1.36)\end{array}$ & $\begin{array}{c}6.15 \\
(6.29)\end{array}$ & $\begin{array}{c}0.80 \\
(0.80)\end{array}$ & $\begin{array}{c}0.90 \\
(0.88)\end{array}$ & $\begin{array}{c}3.50 \\
(3.50)\end{array}$ & $\begin{array}{c}5.00 \\
(4.88)\end{array}$ & $\begin{array}{c}0.02 \\
(0.02)\end{array}$ \\
\hline 07077800 & $\begin{array}{l}\text { White } \\
\text { River }\end{array}$ & $\begin{array}{c}1886- \\
2009 \\
(94)\end{array}$ & $\begin{array}{c}14.5 \\
(14.5)\end{array}$ & $\begin{array}{c}0.68 \\
(0.72)\end{array}$ & $\begin{array}{c}0.81 \\
(0.84)\end{array}$ & $\begin{array}{c}1.00 \\
(1.09)\end{array}$ & $\begin{array}{c}2.02 \\
(2.11)\end{array}$ & $\begin{array}{c}2.28 \\
(2.38)\end{array}$ & $\begin{array}{c}2.94 \\
(3.02)\end{array}$ & $\begin{array}{c}7.08 \\
(7.27)\end{array}$ & $\begin{array}{c}0.75 \\
(0.94)\end{array}$ & $\begin{array}{c}0.60 \\
(0.69)\end{array}$ & $\begin{array}{c}3.00 \\
(3.16)\end{array}$ & $\begin{array}{c}3.00 \\
(3.24)\end{array}$ & $\begin{array}{c}0.02 \\
(0.02)\end{array}$ \\
\hline 07077820 & $\begin{array}{l}\text { White } \\
\text { River }\end{array}$ & $\begin{array}{c}1932- \\
2009 \\
(52)\end{array}$ & $\begin{array}{c}13.4 \\
(13.5)\end{array}$ & $\begin{array}{c}0.65 \\
(0.67)\end{array}$ & $\begin{array}{c}0.80 \\
(0.78)\end{array}$ & $\begin{array}{c}1.01 \\
(1.03)\end{array}$ & $\begin{array}{c}1.89 \\
(1.95)\end{array}$ & $\begin{array}{c}2.16 \\
(2.19)\end{array}$ & $\begin{array}{c}2.66 \\
(2.75)\end{array}$ & $\begin{array}{c}6.79 \\
(6.68)\end{array}$ & $\begin{array}{c}0.50 \\
(0.71)\end{array}$ & $\begin{array}{c}0.50 \\
(0.64)\end{array}$ & $\begin{array}{c}3.00 \\
(2.99)\end{array}$ & $\begin{array}{c}3.00 \\
(3.04)\end{array}$ & $\begin{array}{c}0.02 \\
(0.02)\end{array}$ \\
\hline 07263500 & $\begin{array}{c}\text { Arkansas } \\
\text { River }\end{array}$ & $\begin{array}{c}1987- \\
2009 \\
(4)\end{array}$ & $\begin{array}{c}6.41 \\
(6.06)\end{array}$ & $\begin{array}{c}0.19 \\
(0.22)\end{array}$ & $\begin{array}{c}0.25 \\
(0.28)\end{array}$ & $\begin{array}{c}0.40 \\
(0.40)\end{array}$ & $\begin{array}{c}1.20 \\
(1.23)\end{array}$ & $\begin{array}{c}1.26 \\
(1.29)\end{array}$ & $\begin{array}{c}1.41 \\
(1.41)\end{array}$ & $\begin{array}{c}12.8 \\
(12.4)\end{array}$ & $\begin{array}{c}0.22 \\
(0.21)\end{array}$ & $\begin{array}{c}0.22 \\
(0.23)\end{array}$ & $\begin{array}{c}1.00 \\
(1.13)\end{array}$ & $\begin{array}{c}1.25 \\
(1.38)\end{array}$ & $\begin{array}{c}0.03 \\
(0.03)\end{array}$ \\
\hline \multicolumn{16}{|c|}{ Lower Mississippi-Yazoo (0803) } \\
\hline 07265450 & $\begin{array}{l}\text { Mississippi } \\
\text { River }\end{array}$ & $\begin{array}{c}1929- \\
2009 \\
(73)\end{array}$ & $\begin{array}{c}27.4 \\
(29.2)\end{array}$ & $\begin{array}{c}1.06 \\
(1.19)\end{array}$ & $\begin{array}{c}1.29 \\
(1.42)\end{array}$ & $\begin{array}{c}1.73 \\
(1.96)\end{array}$ & $\begin{array}{c}2.97 \\
(4.36)\end{array}$ & $\begin{array}{c}3.92 \\
(9.15)\end{array}$ & $\begin{array}{c}6.87 \\
(10.1)\end{array}$ & $\begin{array}{c}11.8 \\
(14.3)\end{array}$ & $\begin{array}{c}1.20 \\
(1.32)\end{array}$ & $\begin{array}{c}1.35 \\
(1.56)\end{array}$ & $\begin{array}{c}3.50 \\
(3.77)\end{array}$ & $\begin{array}{c}4.00 \\
(4.20)\end{array}$ & $\begin{array}{c}0.03 \\
(0.04)\end{array}$ \\
\hline
\end{tabular}

${ }^{a}$ Period shown is for calendar years and includes gaps if data collection was discontinuous. Number of complete calendar years shown in parentheses.

${ }^{\mathrm{b}}$ Percentile spread measures are calculated as the difference between the indicated percentiles divided by the median where $7525=(\mathrm{p} 75-\mathrm{p} 25) / \mathrm{p} 50$, $8020=(\mathrm{p} 80-\mathrm{p} 20) / \mathrm{p} 50$, and $9010=(\mathrm{p} 90-\mathrm{p} 10) / \mathrm{p} 50$.

${ }^{\mathrm{c}}$ Percentile ratio measures are calculated as the ratios of the indicated percentiles where $7525=\mathrm{p} 75 / \mathrm{p} 25,8020=\mathrm{p} 80 / \mathrm{p} 20$, and $9010=\mathrm{p} 90 / \mathrm{p} 10$.

${ }^{d}$ Magnitude and duration metrics (McMahon and others, 2003): Cum_50, sum incremental change, absolute value gage height, normalized to the median incremental change, absolute value gage height; Rise_50, median rise in gage height, in feet; Fall_50, median fall in gage height, in feet; Risedur_50, median rise duration, in days; Falldur_50, median fall duration, in days.

${ }^{\mathrm{e}}$ Inactive station. 
Table 9A. Selected hydrologic metrics for discharge by water year for gaging stations in the contributing watersheds of the Cache and White River National Wildlife Refuges and vicinity, Arkansas, Missouri, and Oklahoma.

[Major drainage boundaries and locations of U.S. Geological Survey (USGS) gaging stations shown in figure 1; USGS hydrologic subregions, and subregion hydrologic-unit codes, listed as subheadings and also shown in figure 1; water year, October 1, preceding calendar year, through September 30, current calendar year; all values unitless unless stated otherwise; LCV5, coefficient of variation of the set of every 5 th percentile of $\log _{10}$ discharge; RBFI, RichardsBaker flashiness index (Baker and others, 2004); median and mean values of hydrologic metrics by water year are given for each metric (mean values in parentheses); - , too few annual values to compute the indicated metric]

\begin{tabular}{|c|c|c|c|c|c|c|c|c|c|c|c|c|c|c|c|}
\hline \multirow{2}{*}{$\begin{array}{c}\text { USGS } \\
\text { station } \\
\text { number }\end{array}$} & \multirow{2}{*}{$\begin{array}{l}\text { River } \\
\text { name }\end{array}$} & \multirow{2}{*}{$\begin{array}{c}\text { Period } \\
\text { of } \\
\text { recorda }^{a}\end{array}$} & \multirow{2}{*}{ LCV5 } & \multicolumn{3}{|c|}{$\begin{array}{c}\text { Percentile } \\
\text { spread measures }^{b}\end{array}$} & \multicolumn{3}{|c|}{$\begin{array}{c}\text { Percentile } \\
\text { ratio measures }\end{array}$} & \multicolumn{3}{|c|}{$\begin{array}{l}\text { Magnitude } \\
\text { metrics }^{\mathrm{d}}\end{array}$} & \multicolumn{2}{|c|}{$\begin{array}{l}\text { Duration metrics, } \\
\text { in days }{ }^{d}\end{array}$} & \multirow{2}{*}{ RBFI } \\
\hline & & & & 7525 & 8020 & 9010 & 7525 & 8020 & 9010 & $\begin{array}{c}\text { Cum } \\
-50\end{array}$ & $\begin{array}{r}\text { Rise } \\
50\end{array}$ & $\begin{array}{r}\text { Fall } \\
50 \\
\end{array}$ & $\begin{array}{c}\text { Risedur } \\
\quad 50\end{array}$ & $\begin{array}{c}\text { Falldur } \\
\quad 50\end{array}$ & \\
\hline \multicolumn{16}{|c|}{ Upper White (1101) } \\
\hline 07074500 & $\begin{array}{l}\text { White } \\
\text { River }\end{array}$ & $\begin{array}{c}1928- \\
2009 \\
(75)\end{array}$ & $\begin{array}{c}6.14 \\
(6.26)\end{array}$ & $\begin{array}{c}0.98 \\
(1.15)\end{array}$ & $\begin{array}{c}1.17 \\
(1.45)\end{array}$ & $\begin{array}{c}1.84 \\
(2.25)\end{array}$ & $\begin{array}{c}2.71 \\
(2.97)\end{array}$ & $\begin{array}{c}3.44 \\
(3.73)\end{array}$ & $\begin{array}{c}5.44 \\
(6.18)\end{array}$ & $\begin{array}{c}37.2 \\
(42.2)\end{array}$ & $\begin{array}{c}2,000 \\
(2,190)\end{array}$ & $\begin{array}{c}2,400 \\
(2,420)\end{array}$ & $\begin{array}{c}2.00 \\
(2.00)\end{array}$ & $\begin{array}{c}2.00 \\
(2.50)\end{array}$ & $\begin{array}{c}0.082 \\
(0.083)\end{array}$ \\
\hline \multicolumn{16}{|c|}{ Lower Mississippi-St Francis (0802) } \\
\hline 07047970 & $\begin{array}{l}\text { Mississippi } \\
\text { River }\end{array}$ & $\begin{array}{c}1928- \\
1977 \\
(49)\end{array}$ & $\begin{array}{c}4.28 \\
(4.34)\end{array}$ & $\begin{array}{c}0.95 \\
(1.03)\end{array}$ & $\begin{array}{c}1.17 \\
(1.29)\end{array}$ & $\begin{array}{c}1.74 \\
(1.92)\end{array}$ & $\begin{array}{c}2.51 \\
(2.64)\end{array}$ & $\begin{array}{c}3.09 \\
(3.24)\end{array}$ & $\begin{array}{c}4.60 \\
(5.00)\end{array}$ & $\begin{array}{c}15.0 \\
(15.1)\end{array}$ & $\begin{array}{c}30,000 \\
(40,600)\end{array}$ & $\begin{array}{c}33,500 \\
(42,700)\end{array}$ & $\begin{array}{c}4.00 \\
(4.46)\end{array}$ & $\begin{array}{c}5.00 \\
(5.07)\end{array}$ & $\begin{array}{c}0.034 \\
(0.034)\end{array}$ \\
\hline 07076750 & $\begin{array}{l}\text { White } \\
\text { River }\end{array}$ & $\begin{array}{c}1928- \\
2009 \\
(8)\end{array}$ & $\begin{array}{c}5.25 \\
(5.41)\end{array}$ & $\begin{array}{c}0.81 \\
(0.80)\end{array}$ & $\begin{array}{c}1.06 \\
(1.06)\end{array}$ & $\begin{array}{c}1.54 \\
(1.68)\end{array}$ & $\begin{array}{c}2.15 \\
(2.42)\end{array}$ & $\begin{array}{c}2.75 \\
(3.10)\end{array}$ & $\begin{array}{c}4.39 \\
(5.12)\end{array}$ & $\begin{array}{c}18.1 \\
(17.4)\end{array}$ & $\begin{array}{c}1,460 \\
(1,500)\end{array}$ & $\begin{array}{c}2,200 \\
(2,070)\end{array}$ & $\begin{array}{l}3.00 \\
(3.00)\end{array}$ & $\begin{array}{c}3.00 \\
(3.38)\end{array}$ & $\begin{array}{r}0.044 \\
(0.041)\end{array}$ \\
\hline 07077380 & $\begin{array}{l}\text { Cache } \\
\text { River }\end{array}$ & $\begin{array}{c}1965- \\
2009 \\
(44)\end{array}$ & $\begin{array}{l}24.6 \\
(25.3)\end{array}$ & $\begin{array}{c}3.11 \\
(3.37)\end{array}$ & $\begin{array}{c}4.22 \\
(4.78)\end{array}$ & $\begin{array}{c}7.83 \\
(8.63)\end{array}$ & $\begin{array}{c}11.6 \\
(13.6)\end{array}$ & $\begin{array}{c}20.3 \\
(21.0)\end{array}$ & $\begin{array}{l}54.8 \\
(134)\end{array}$ & $\begin{array}{c}234 \\
(234)\end{array}$ & $\begin{array}{c}298 \\
(336)\end{array}$ & $\begin{array}{c}215 \\
(274)\end{array}$ & $\begin{array}{c}2.00 \\
(2.24)\end{array}$ & $\begin{array}{c}4.00 \\
(4.08)\end{array}$ & $\begin{array}{c}0.231 \\
(0.227)\end{array}$ \\
\hline 07077500 & $\begin{array}{l}\text { Cache } \\
\text { River }\end{array}$ & $\begin{array}{c}1928- \\
2009 \\
(60)\end{array}$ & $\begin{array}{c}20.4 \\
(21.0)\end{array}$ & $\begin{array}{c}2.50 \\
(2.99)\end{array}$ & $\begin{array}{c}3.37 \\
(4.09)\end{array}$ & $\begin{array}{c}5.78 \\
(7.52)\end{array}$ & $\begin{array}{c}8.12 \\
(9.93)\end{array}$ & $\begin{array}{c}12.9 \\
(15.5)\end{array}$ & $\begin{array}{c}33.7 \\
(46.2)\end{array}$ & $\begin{array}{c}92.1 \\
(104)\end{array}$ & $\begin{array}{c}221 \\
(241)\end{array}$ & $\begin{array}{c}217 \\
(236)\end{array}$ & $\begin{array}{c}3.00 \\
(3.20)\end{array}$ & $\begin{array}{c}4.00 \\
(4.19)\end{array}$ & $\begin{array}{c}0.108 \\
(0.112)\end{array}$ \\
\hline 07077555 & $\begin{array}{l}\text { Cache } \\
\text { River }\end{array}$ & $\begin{array}{c}1987- \\
2009 \\
(21)\end{array}$ & $\begin{array}{c}16.4 \\
(17.6)\end{array}$ & $\begin{array}{c}1.84 \\
(2.05)\end{array}$ & $\begin{array}{c}2.26 \\
(2.51)\end{array}$ & $\begin{array}{c}3.71 \\
(3.88)\end{array}$ & $\begin{array}{c}5.74 \\
(6.78)\end{array}$ & $\begin{array}{c}7.93 \\
(10.3)\end{array}$ & $\begin{array}{c}21.8 \\
(29.3)\end{array}$ & $\begin{array}{c}41.7 \\
(41.9)\end{array}$ & $\begin{array}{c}275 \\
(306)\end{array}$ & $\begin{array}{c}170 \\
(287)\end{array}$ & $\begin{array}{c}5.50 \\
(5.71)\end{array}$ & $\begin{array}{c}6.00 \\
(6.33)\end{array}$ & $\begin{array}{c}0.069 \\
(0.072)\end{array}$ \\
\hline 07077700 & $\begin{array}{l}\text { Bayou } \\
\quad \text { DeView }\end{array}$ & $\begin{array}{c}1939- \\
2009 \\
(48)\end{array}$ & $\begin{array}{c}31.6 \\
(32.5)\end{array}$ & $\begin{array}{c}4.46 \\
(4.91)\end{array}$ & $\begin{array}{c}6.19 \\
(6.78)\end{array}$ & $\begin{array}{c}11.7 \\
(15.7)\end{array}$ & $\begin{array}{c}21.0 \\
(33.4)\end{array}$ & $\begin{array}{c}39.4 \\
(83.8)\end{array}$ & $\begin{array}{c}166 \\
(356)\end{array}$ & $\begin{array}{c}242 \\
(315)\end{array}$ & $\begin{array}{c}156 \\
(167)\end{array}$ & $\begin{array}{c}128 \\
(138)\end{array}$ & $\begin{array}{c}3.00 \\
(2.91)\end{array}$ & $\begin{array}{c}5.00 \\
(4.38)\end{array}$ & $\begin{array}{c}0.169 \\
(0.179)\end{array}$ \\
\hline $07077952^{\mathrm{e}}$ & Big Creek & $\begin{array}{c}1971- \\
1972 \\
(2)\end{array}$ & $\begin{array}{c}30.2 \\
(30.2)\end{array}$ & - & - & - & - & - & - & - & - & - & - & - & - \\
\hline $07078000^{\mathrm{e}}$ & $\begin{array}{l}\text { LaGrue } \\
\text { Bayou }\end{array}$ & $\begin{array}{c}1936- \\
1954 \\
(19)\end{array}$ & $\begin{array}{c}50.6 \\
(54.7)\end{array}$ & $\begin{array}{c}4.02 \\
(5.27)\end{array}$ & $\begin{array}{c}6.17 \\
(8.39)\end{array}$ & $\begin{array}{c}13.8 \\
(19.3)\end{array}$ & $\begin{array}{l}21.7 \\
(34.8)\end{array}$ & $\begin{array}{c}43.1 \\
(90.1)\end{array}$ & $\begin{array}{c}171 \\
(1,030)\end{array}$ & $\begin{array}{c}390 \\
(525)\end{array}$ & $\begin{array}{l}42.0 \\
(63.7)\end{array}$ & $\begin{array}{c}22.5 \\
(47.8)\end{array}$ & $\begin{array}{l}3.00 \\
(2.63)\end{array}$ & $\begin{array}{c}3.00 \\
(2.69)\end{array}$ & $\begin{array}{c}0.222 \\
(0.223)\end{array}$ \\
\hline 07264000 & $\begin{array}{l}\text { Bayou } \\
\text { Meto }\end{array}$ & $\begin{array}{c}1955- \\
2009 \\
(54)\end{array}$ & $\begin{array}{c}38.3 \\
(41.2)\end{array}$ & $\begin{array}{c}3.40 \\
(4.43)\end{array}$ & $\begin{array}{c}4.98 \\
(6.12)\end{array}$ & $\begin{array}{c}9.54 \\
(11.5)\end{array}$ & $\begin{array}{c}17.7 \\
(25.2)\end{array}$ & $\begin{array}{c}31.6 \\
(68.2)\end{array}$ & $\begin{array}{c}113 \\
(221)\end{array}$ & $\begin{array}{c}166 \\
(217)\end{array}$ & $\begin{array}{c}16.3 \\
(32.7)\end{array}$ & $\begin{array}{c}14.3 \\
(23.8)\end{array}$ & $\begin{array}{c}2.00 \\
(2.31)\end{array}$ & $\begin{array}{c}3.00 \\
(3.22)\end{array}$ & $\begin{array}{c}0.155 \\
(0.157)\end{array}$ \\
\hline
\end{tabular}


Table 9A. Selected hydrologic metrics for discharge by water year for gaging stations in the contributing watersheds of the Cache and White River National Wildlife Refuges and vicinity, Arkansas, Missouri, and Oklahoma.-Continued

[Major drainage boundaries and locations of U.S. Geological Survey (USGS) gaging stations shown in figure 1; USGS hydrologic subregions, and subregion hydrologic-unit codes, listed as subheadings and also shown in figure 1; water year, October 1, preceding calendar year, through September 30, current calendar year; all values unitless unless stated otherwise; LCV5, coefficient of variation of the set of every 5 th percentile of $\log _{10}$ discharge; RBFI, RichardsBaker flashiness index (Baker and others, 2004); median and mean values of hydrologic metrics by water year are given for each metric (mean values in parentheses); - , too few annual values to compute the indicated metric]

\begin{tabular}{|c|c|c|c|c|c|c|c|c|c|c|c|c|c|c|c|}
\hline \multirow{2}{*}{$\begin{array}{c}\text { USGS } \\
\text { station } \\
\text { number }\end{array}$} & \multirow{2}{*}{$\begin{array}{l}\text { River } \\
\text { name }\end{array}$} & \multirow{2}{*}{$\begin{array}{c}\text { Period } \\
\text { of } \\
\text { record }^{\mathrm{a}}\end{array}$} & \multirow{2}{*}{ LCV5 } & \multicolumn{3}{|c|}{$\begin{array}{c}\text { Percentile } \\
\text { spread measures }^{b}\end{array}$} & \multicolumn{3}{|c|}{$\begin{array}{c}\text { Percentile } \\
\text { ratio measures }^{c}\end{array}$} & \multicolumn{3}{|c|}{$\begin{array}{l}\text { Magnitude } \\
\text { metrics }^{d}\end{array}$} & \multicolumn{2}{|c|}{$\begin{array}{l}\text { Duration metrics, } \\
\text { in days }\end{array}$} & \multirow{2}{*}{ RBFI } \\
\hline & & & & 7525 & 8020 & 9010 & 7525 & 8020 & 9010 & $\begin{array}{c}\text { Cum } \\
-50\end{array}$ & $\begin{array}{r}\text { Rise } \\
50\end{array}$ & $\begin{array}{r}\text { Fall } \\
50\end{array}$ & $\begin{array}{c}\text { Risedur } \\
\quad 50\end{array}$ & $\begin{array}{c}\text { Falldur } \\
50\end{array}$ & \\
\hline \multicolumn{16}{|c|}{ Lower Arkansas (1111) } \\
\hline 07263450 & $\begin{array}{c}\text { Arkansas } \\
\text { River }\end{array}$ & $\begin{array}{c}1928- \\
2009 \\
(79)\end{array}$ & $\begin{array}{c}9.92 \\
(9.91)\end{array}$ & $\begin{array}{c}1.59 \\
(1.74)\end{array}$ & $\begin{array}{c}2.06 \\
(2.24)\end{array}$ & $\begin{array}{c}3.33 \\
(3.73)\end{array}$ & $\begin{array}{c}4.46 \\
(5.49)\end{array}$ & $\begin{array}{c}6.11 \\
(8.27)\end{array}$ & $\begin{array}{c}15.6 \\
(22.3)\end{array}$ & $\begin{array}{c}84.8 \\
(90.5)\end{array}$ & $\begin{array}{c}7,300 \\
(7,540)\end{array}$ & $\begin{array}{c}8,200 \\
(7,890)\end{array}$ & $\begin{array}{c}2.00 \\
(2.16)\end{array}$ & $\begin{array}{c}2.00 \\
(2.69)\end{array}$ & $\begin{array}{c}0.143 \\
(0.153)\end{array}$ \\
\hline $07263500^{\mathrm{e}}$ & $\begin{array}{l}\text { Arkansas } \\
\text { River }\end{array}$ & $\begin{array}{c}1928- \\
1970 \\
(43)\end{array}$ & $\begin{array}{c}9.92 \\
(9.39)\end{array}$ & $\begin{array}{c}1.64 \\
(1.73)\end{array}$ & $\begin{array}{c}2.05 \\
(2.27)\end{array}$ & $\begin{array}{c}3.63 \\
(4.11)\end{array}$ & $\begin{array}{c}4.10 \\
(5.03)\end{array}$ & $\begin{array}{c}5.52 \\
(7.39)\end{array}$ & $\begin{array}{c}14.2 \\
(18.4)\end{array}$ & $\begin{array}{c}83.4 \\
(88.4)\end{array}$ & $\begin{array}{c}5,500 \\
(6,720)\end{array}$ & $\begin{array}{c}5,100 \\
(5,750)\end{array}$ & $\begin{array}{c}2.00 \\
(2.38)\end{array}$ & $\begin{array}{c}3.00 \\
(3.27)\end{array}$ & $\begin{array}{c}0.132 \\
(0.136)\end{array}$ \\
\hline \multicolumn{16}{|c|}{ Lower Mississippi-Yazoo (0803) } \\
\hline 07265450 & $\begin{array}{l}\text { Mississippi } \\
\text { River }\end{array}$ & $\begin{array}{c}1928- \\
1980 \\
(52)\end{array}$ & $\begin{array}{c}4.15 \\
(4.27)\end{array}$ & $\begin{array}{c}0.94 \\
(1.01)\end{array}$ & $\begin{array}{c}1.17 \\
(1.26)\end{array}$ & $\begin{array}{c}1.76 \\
(1.87)\end{array}$ & $\begin{array}{c}2.46 \\
(2.64)\end{array}$ & $\begin{array}{c}2.93 \\
(3.26)\end{array}$ & $\begin{array}{c}4.71 \\
(5.01)\end{array}$ & $\begin{array}{c}12.8 \\
(13.0)\end{array}$ & $\begin{array}{c}42,000 \\
(46,900)\end{array}$ & $\begin{array}{c}42,800 \\
(50,300)\end{array}$ & $\begin{array}{c}5.00 \\
(4.86)\end{array}$ & $\begin{array}{c}5.75 \\
(5.63)\end{array}$ & $\begin{array}{c}0.030 \\
(0.029)\end{array}$ \\
\hline
\end{tabular}

${ }^{a}$ Period shown is for water years and includes gaps if data collection was discontinuous. Number of complete water years shown in parentheses.

${ }^{\mathrm{b}}$ Percentile spread measures are calculated as the difference between the indicated percentiles divided by the median where $7525=(\mathrm{p} 75-\mathrm{p} 25) / \mathrm{p} 50$, $8020=(\mathrm{p} 80-\mathrm{p} 20) / \mathrm{p} 50$, and $9010=(\mathrm{p} 90-\mathrm{p} 10) / \mathrm{p} 50$.

${ }^{\mathrm{c}}$ Percentile ratio measures are calculated as the ratios of the indicated percentiles where $7525=\mathrm{p} 75 / \mathrm{p} 25,8020=\mathrm{p} 80 / \mathrm{p} 20$, and $9010=\mathrm{p} 90 / \mathrm{p} 10$.

${ }^{\mathrm{d}}$ Magnitude and duration metrics (McMahon and others, 2003): Cum_50, sum incremental change, absolute value discharge, normalized to the median incremental change, absolute value discharge; Rise_50, median rise in discharge, in cubic feet per second; Fall_50, median fall in discharge, in cubic feet per second; Risedur_50, median rise duration, in days; Falldur_50, median fall duration, in days.

${ }^{\mathrm{e}}$ Inactive station. 
Table 9B. Selected hydrologic metrics for discharge by calendar year for gaging stations in the contributing watersheds of the Cache and White River National Wildlife Refuges and vicinity, Arkansas, Missouri, and Oklahoma.

[Major drainage boundaries and locations of U.S. Geological Survey (USGS) gaging stations shown in figure 1; USGS hydrologic subregions, and subregion hydrologic-unit codes, listed as subheadings and also shown in figure 1; water year, October 1, preceding calendar year, through September 30, current calendar year; all values unitless unless stated otherwise; LCV5, coefficient of variation of the set of every 5th percentile of $\log _{10}$ discharge; RBFI, RichardsBaker flashiness index (Baker and others, 2004); median and mean values of hydrologic metrics by water year are given for each metric (mean values in parentheses); - , too few annual values to compute the indicated metric]

\begin{tabular}{|c|c|c|c|c|c|c|c|c|c|c|c|c|c|c|c|}
\hline \multirow{2}{*}{$\begin{array}{c}\text { USGS } \\
\text { station } \\
\text { number }\end{array}$} & \multirow{2}{*}{$\begin{array}{l}\text { River } \\
\text { name }\end{array}$} & \multirow{2}{*}{$\begin{array}{c}\text { Period } \\
\text { of } \\
\text { record }^{\mathrm{a}}\end{array}$} & \multirow{2}{*}{ LCV5 } & \multicolumn{3}{|c|}{$\begin{array}{c}\text { Percentile } \\
\text { spread measures }^{b}\end{array}$} & \multicolumn{3}{|c|}{$\begin{array}{c}\text { Percentile } \\
\text { ratio measures }^{c}\end{array}$} & \multicolumn{3}{|c|}{$\begin{array}{c}\text { Magnitude } \\
\text { metrics }^{\mathrm{d}}\end{array}$} & \multicolumn{2}{|c|}{$\begin{array}{c}\text { Duration metrics, } \\
\text { in days }{ }^{d}\end{array}$} & \multirow{2}{*}{ RBFI } \\
\hline & & & & 7525 & 8020 & 9010 & 7525 & 8020 & 9010 & $\begin{array}{c}\text { Cum } \\
50\end{array}$ & $\begin{array}{r}\text { Rise } \\
50\end{array}$ & $\begin{array}{r}\text { Fall } \\
50\end{array}$ & $\begin{array}{c}\text { Risedur } \\
50\end{array}$ & $\begin{array}{c}\text { Falldur } \\
-50\end{array}$ & \\
\hline \multicolumn{16}{|c|}{ Upper White (1101) } \\
\hline 07074500 & $\begin{array}{l}\text { White } \\
\text { River }\end{array}$ & $\begin{array}{c}1927- \\
2009 \\
(74)\end{array}$ & $\begin{array}{c}6.15 \\
(6.38)\end{array}$ & $\begin{array}{c}1.06 \\
(1.20)\end{array}$ & $\begin{array}{c}1.31 \\
(1.52)\end{array}$ & $\begin{array}{c}2.07 \\
(2.41)\end{array}$ & $\begin{array}{c}2.66 \\
(2.96)\end{array}$ & $\begin{array}{c}3.39 \\
(3.72)\end{array}$ & $\begin{array}{c}5.52 \\
(6.23)\end{array}$ & $\begin{array}{c}38.3 \\
(42.9)\end{array}$ & $\begin{array}{c}1,910 \\
(2,140)\end{array}$ & $\begin{array}{c}2,250 \\
(2,360)\end{array}$ & $\begin{array}{c}2.00 \\
(2.03)\end{array}$ & $\begin{array}{c}2.50 \\
(2.53)\end{array}$ & $\begin{array}{c}0.08 \\
(0.08)\end{array}$ \\
\hline \multicolumn{16}{|c|}{ Lower Mississippi-St Francis (0802) } \\
\hline 07047970 & $\begin{array}{l}\text { Mississippi } \\
\text { River }\end{array}$ & $\begin{array}{c}1928- \\
1977 \\
(49)\end{array}$ & $\begin{array}{c}4.21 \\
(4.41)\end{array}$ & $\begin{array}{c}0.96 \\
(1.07)\end{array}$ & $\begin{array}{c}1.19 \\
(1.32)\end{array}$ & $\begin{array}{c}1.96 \\
(1.93)\end{array}$ & $\begin{array}{c}2.56 \\
(2.80)\end{array}$ & $\begin{array}{c}3.05 \\
(3.41)\end{array}$ & $\begin{array}{c}4.80 \\
(5.15)\end{array}$ & $\begin{array}{c}14.1 \\
(14.9)\end{array}$ & $\begin{array}{c}35,000 \\
(40,200)\end{array}$ & $\begin{array}{c}39,500 \\
(40,900)\end{array}$ & $\begin{array}{c}4.50 \\
(4.46)\end{array}$ & $\begin{array}{c}5.00 \\
(5.04)\end{array}$ & $\begin{array}{c}0.03 \\
(0.03)\end{array}$ \\
\hline 07076750 & $\begin{array}{l}\text { White } \\
\text { River }\end{array}$ & $\begin{array}{c}1927- \\
2009 \\
(6)\end{array}$ & $\begin{array}{c}4.94 \\
(5.33)\end{array}$ & $\begin{array}{c}0.74 \\
(0.86)\end{array}$ & $\begin{array}{c}0.99 \\
(1.06)\end{array}$ & $\begin{array}{c}1.36 \\
(1.63)\end{array}$ & $\begin{array}{c}2.10 \\
(2.45)\end{array}$ & $\begin{array}{c}2.74 \\
(3.03)\end{array}$ & $\begin{array}{c}4.45 \\
(5.02)\end{array}$ & $\begin{array}{c}15.2 \\
(15.3)\end{array}$ & $\begin{array}{c}1,650 \\
(1,590)\end{array}$ & $\begin{array}{c}2,030 \\
(2,060)\end{array}$ & $\begin{array}{c}3.00 \\
(2.83)\end{array}$ & $\begin{array}{c}3.00 \\
(3.08)\end{array}$ & $\begin{array}{c}0.04 \\
(0.04)\end{array}$ \\
\hline 07077380 & $\begin{array}{l}\text { Cache } \\
\text { River }\end{array}$ & $\begin{array}{c}1964- \\
2009 \\
(44)\end{array}$ & $\begin{array}{c}26.2 \\
(25.9)\end{array}$ & $\begin{array}{c}3.27 \\
(3.48)\end{array}$ & $\begin{array}{c}5.08 \\
(4.98)\end{array}$ & $\begin{array}{c}9.74 \\
(9.34)\end{array}$ & $\begin{array}{c}12.1 \\
(12.5)\end{array}$ & $\begin{array}{c}20.0 \\
(26.2)\end{array}$ & $\begin{array}{c}70.0 \\
(151)\end{array}$ & $\begin{array}{c}225 \\
(228)\end{array}$ & $\begin{array}{c}278 \\
(312)\end{array}$ & $\begin{array}{c}232 \\
(278)\end{array}$ & $\begin{array}{c}2.00 \\
(2.24)\end{array}$ & $\begin{array}{c}4.00 \\
(4.03)\end{array}$ & $\begin{array}{c}0.21 \\
(0.22)\end{array}$ \\
\hline 07077500 & $\begin{array}{l}\text { Cache } \\
\text { River }\end{array}$ & $\begin{array}{c}1927- \\
2009 \\
(59)\end{array}$ & $\begin{array}{c}21.8 \\
(22.0)\end{array}$ & $\begin{array}{c}2.81 \\
(3.42)\end{array}$ & $\begin{array}{c}3.93 \\
(4.68)\end{array}$ & $\begin{array}{c}6.30 \\
(8.55)\end{array}$ & $\begin{array}{c}8.85 \\
(10.4)\end{array}$ & $\begin{array}{c}14.9 \\
(17.3)\end{array}$ & $\begin{array}{c}43.4 \\
(53.0)\end{array}$ & $\begin{array}{c}99.0 \\
(108)\end{array}$ & $\begin{array}{c}212 \\
(240)\end{array}$ & $\begin{array}{c}186 \\
(223)\end{array}$ & $\begin{array}{c}3.00 \\
(3.19)\end{array}$ & $\begin{array}{c}4.00 \\
(4.19)\end{array}$ & $\begin{array}{c}0.11 \\
(0.11)\end{array}$ \\
\hline 07077555 & $\begin{array}{l}\text { Cache } \\
\text { River }\end{array}$ & $\begin{array}{c}1987- \\
2009 \\
(21)\end{array}$ & $\begin{array}{c}18.0 \\
(18.4)\end{array}$ & $\begin{array}{c}1.84 \\
(2.10)\end{array}$ & $\begin{array}{c}2.42 \\
(2.62)\end{array}$ & $\begin{array}{c}3.53 \\
(4.39)\end{array}$ & $\begin{array}{c}6.22 \\
(7.03)\end{array}$ & $\begin{array}{c}8.81 \\
(11.6)\end{array}$ & $\begin{array}{c}25.5 \\
(35.3)\end{array}$ & $\begin{array}{c}40.7 \\
(42.4)\end{array}$ & $\begin{array}{c}210 \\
(290)\end{array}$ & $\begin{array}{c}204 \\
(272)\end{array}$ & $\begin{array}{c}5.50 \\
(5.62)\end{array}$ & $\begin{array}{c}6.00 \\
(6.31)\end{array}$ & $\begin{array}{c}0.07 \\
(0.07)\end{array}$ \\
\hline 07077700 & $\begin{array}{l}\text { Bayou } \\
\text { DeView }\end{array}$ & $\begin{array}{c}1939- \\
2009 \\
(47)\end{array}$ & $\begin{array}{c}31.9 \\
(32.4)\end{array}$ & $\begin{array}{c}4.09 \\
(5.20)\end{array}$ & $\begin{array}{c}5.59 \\
(7.63)\end{array}$ & $\begin{array}{c}11.5 \\
(14.9)\end{array}$ & $\begin{array}{c}18.8 \\
(33.1)\end{array}$ & $\begin{array}{c}35.9 \\
(109)\end{array}$ & $\begin{array}{c}184 \\
(778)\end{array}$ & $\begin{array}{c}235 \\
(287)\end{array}$ & $\begin{array}{c}162 \\
(174)\end{array}$ & $\begin{array}{c}130 \\
(137)\end{array}$ & $\begin{array}{c}3.00 \\
(2.85)\end{array}$ & $\begin{array}{c}4.50 \\
(4.32)\end{array}$ & $\begin{array}{c}0.16 \\
(0.17)\end{array}$ \\
\hline $07077952^{\mathrm{e}}$ & Big Creek & $\begin{array}{c}1970- \\
1972 \\
(1)\end{array}$ & - & - & - & - & - & - & - & - & - & - & - & - & - \\
\hline $07078000^{\mathrm{e}}$ & $\begin{array}{l}\text { LaGrue } \\
\text { Bayou }\end{array}$ & $\begin{array}{c}1935- \\
1954 \\
(18)\end{array}$ & $\begin{array}{c}50.3 \\
(53.4)\end{array}$ & $\begin{array}{c}4.14 \\
(5.30)\end{array}$ & $\begin{array}{c}6.32 \\
(8.51)\end{array}$ & $\begin{array}{c}11.5 \\
(17.3)\end{array}$ & $\begin{array}{c}19.4 \\
(37.6)\end{array}$ & $\begin{array}{c}41.4 \\
(103)\end{array}$ & $\begin{array}{c}159 \\
(536)\end{array}$ & $\begin{array}{c}320 \\
(483)\end{array}$ & $\begin{array}{c}43.2 \\
(56.3)\end{array}$ & $\begin{array}{c}22.8 \\
(40.1)\end{array}$ & $\begin{array}{c}3.00 \\
(2.58)\end{array}$ & $\begin{array}{c}3.25 \\
(3.69)\end{array}$ & $\begin{array}{c}0.22 \\
(0.22)\end{array}$ \\
\hline 07264000 & $\begin{array}{l}\text { Bayou } \\
\text { Meto }\end{array}$ & $\begin{array}{c}1954- \\
2009 \\
(54)\end{array}$ & $\begin{array}{c}37.7 \\
(40.08)\end{array}$ & $\begin{array}{c}3.31 \\
(4.29)\end{array}$ & $\begin{array}{c}4.96 \\
(5.97)\end{array}$ & $\begin{array}{c}10.02 \\
(11.30)\end{array}$ & $\begin{array}{c}16.5 \\
(27.2)\end{array}$ & $\begin{array}{c}31.5 \\
(54.7)\end{array}$ & $\begin{array}{c}114 \\
(205)\end{array}$ & $\begin{array}{c}174 \\
(212)\end{array}$ & $\begin{array}{c}16.3 \\
(32.7)\end{array}$ & $\begin{array}{c}14.0 \\
(26.5)\end{array}$ & $\begin{array}{c}2.00 \\
(2.34)\end{array}$ & $\begin{array}{c}3.00 \\
(3.31)\end{array}$ & $\begin{array}{c}0.16 \\
(0.16)\end{array}$ \\
\hline
\end{tabular}


Table 9B. Selected hydrologic metrics for discharge by calendar year for gaging stations in the contributing watersheds of the Cache and White River National Wildlife Refuges and vicinity, Arkansas, Missouri, and Oklahoma.-Continued

[Major drainage boundaries and locations of U.S. Geological Survey (USGS) gaging stations shown in figure 1; USGS hydrologic subregions, and subregion hydrologic-unit codes, listed as subheadings and also shown in figure 1; water year, October 1, preceding calendar year, through September 30 , current calendar year; all values unitless unless stated otherwise; LCV5, coefficient of variation of the set of every 5th percentile of $\log _{10}$ discharge; RBFI, RichardsBaker flashiness index (Baker and others, 2004); median and mean values of hydrologic metrics by water year are given for each metric (mean values in parentheses); - , too few annual values to compute the indicated metric]

\begin{tabular}{|c|c|c|c|c|c|c|c|c|c|c|c|c|c|c|c|}
\hline \multirow{2}{*}{$\begin{array}{c}\text { USGS } \\
\text { station } \\
\text { number }\end{array}$} & \multirow{2}{*}{$\begin{array}{l}\text { River } \\
\text { name }\end{array}$} & \multirow{2}{*}{$\begin{array}{l}\text { Period } \\
\text { of } \\
\text { record }^{a}\end{array}$} & \multirow{2}{*}{ LCV5 } & \multicolumn{3}{|c|}{$\begin{array}{c}\text { Percentile } \\
\text { spread measures }^{b}\end{array}$} & \multicolumn{3}{|c|}{$\begin{array}{c}\text { Percentile } \\
\text { ratio measures }^{c}\end{array}$} & \multicolumn{3}{|c|}{$\begin{array}{l}\text { Magnitude } \\
\text { metrics }^{d}\end{array}$} & \multicolumn{2}{|c|}{$\begin{array}{c}\text { Duration metrics, } \\
\text { in days }{ }^{\mathbf{d}}\end{array}$} & \multirow{2}{*}{ RBFI } \\
\hline & & & & 7525 & 8020 & 9010 & 7525 & 8020 & 9010 & $\begin{array}{r}\text { Cum } \\
-50\end{array}$ & $\begin{array}{r}\text { Rise } \\
50\end{array}$ & $\begin{array}{r}\text { Fall } \\
50\end{array}$ & $\begin{array}{c}\text { Risedur } \\
50\end{array}$ & $\begin{array}{c}\text { Falldur } \\
-50\end{array}$ & \\
\hline \multicolumn{16}{|c|}{ Lower Arkansas (1111) } \\
\hline 07263450 & $\begin{array}{c}\text { Arkansas } \\
\text { River }\end{array}$ & $\begin{array}{c}1927- \\
2008 \\
(77)\end{array}$ & $\begin{array}{c}10.0 \\
(10.1)\end{array}$ & $\begin{array}{c}1.55 \\
(1.74)\end{array}$ & $\begin{array}{c}2.04 \\
(2.27)\end{array}$ & $\begin{array}{c}3.57 \\
(3.86)\end{array}$ & $\begin{array}{c}4.40 \\
(5.49)\end{array}$ & $\begin{array}{c}6.30 \\
(8.25)\end{array}$ & $\begin{array}{c}17.0 \\
(22.0)\end{array}$ & $\begin{array}{c}86.9 \\
(88.9)\end{array}$ & $\begin{array}{c}7,250 \\
(7,250)\end{array}$ & $\begin{array}{c}7,500 \\
(7,560)\end{array}$ & $\begin{array}{c}2.00 \\
(2.16)\end{array}$ & $\begin{array}{c}2.00 \\
(2.71)\end{array}$ & $\begin{array}{c}0.14 \\
(0.15)\end{array}$ \\
\hline $07263500^{\mathrm{e}}$ & $\begin{array}{l}\text { Arkansas } \\
\text { River }\end{array}$ & $\begin{array}{c}1927- \\
1970 \\
(42)\end{array}$ & $\begin{array}{c}9.03 \\
(9.40)\end{array}$ & $\begin{array}{c}1.55 \\
(1.69)\end{array}$ & $\begin{array}{c}2.06 \\
(2.22)\end{array}$ & $\begin{array}{c}3.74 \\
(4.15)\end{array}$ & $\begin{array}{c}4.27 \\
(4.79)\end{array}$ & $\begin{array}{c}5.93 \\
(6.71)\end{array}$ & $\begin{array}{c}14.3 \\
(16.0)\end{array}$ & $\begin{array}{c}82.9 \\
(86.9)\end{array}$ & $\begin{array}{c}5,050 \\
(6,430)\end{array}$ & $\begin{array}{c}4,970 \\
(5,590)\end{array}$ & $\begin{array}{c}2.00 \\
(2.33)\end{array}$ & $\begin{array}{c}3.00 \\
(3.29)\end{array}$ & $\begin{array}{c}0.13 \\
(0.14)\end{array}$ \\
\hline \multicolumn{16}{|c|}{ Lower Mississippi-Yazoo (0803) } \\
\hline 07265450 & $\begin{array}{l}\text { Mississippi } \\
\text { River }\end{array}$ & $\begin{array}{c}1928- \\
1980 \\
(52)\end{array}$ & $\begin{array}{c}4.15 \\
(4.35)\end{array}$ & $\begin{array}{c}0.96 \\
(1.06)\end{array}$ & $\begin{array}{c}1.18 \\
(1.32)\end{array}$ & $\begin{array}{c}1.79 \\
(1.90)\end{array}$ & $\begin{array}{c}2.51 \\
(2.81)\end{array}$ & $\begin{array}{c}3.07 \\
(3.45)\end{array}$ & $\begin{array}{c}4.84 \\
(5.13)\end{array}$ & $\begin{array}{c}12.3 \\
(12.8)\end{array}$ & $\begin{array}{c}36,800 \\
(43,100)\end{array}$ & $\begin{array}{c}39,800 \\
(50,800)\end{array}$ & $\begin{array}{c}5.00 \\
(4.86)\end{array}$ & $\begin{array}{c}5.00 \\
(5.62)\end{array}$ & $\begin{array}{c}0.03 \\
(0.03)\end{array}$ \\
\hline
\end{tabular}

${ }^{\text {a }}$ Period shown is for calendar years and includes gaps if data collection was discontinuous. Number of complete calendar years shown in parentheses.

${ }^{\mathrm{b}}$ Percentile spread measures are calculated as the difference between the indicated percentiles divided by the median where $7525=(\mathrm{p} 75-\mathrm{p} 25) / \mathrm{p} 50$, $8020=(\mathrm{p} 80-\mathrm{p} 20) / \mathrm{p} 50$, and $9010=(\mathrm{p} 90-\mathrm{p} 10) / \mathrm{p} 50$.

${ }^{\mathrm{c}}$ Percentile ratio measures are calculated as the ratios of the indicated percentiles where $7525=\mathrm{p} 75 / \mathrm{p} 25,8020=\mathrm{p} 80 / \mathrm{p} 20$, and $9010=\mathrm{p} 90 / \mathrm{p} 10$.

${ }^{\mathrm{d}}$ Magnitude and duration metrics (McMahon and others, 2003): Cum_50, sum incremental change, absolute value discharge, normalized to the median incremental change, absolute value discharge; Rise_50, median rise in discharge, in cubic feet per second; Fall_50, median fall in discharge, in cubic feet per second; Risedur_50, median rise duration, in days; Falldur_50, median fall duration, in days.

e Inactive station. 
Table 10. Graphical summary files for plots of gage height and discharge data collected at gaging stations in the contributing watersheds of the Cache and White River National Wildlife Refuges and vicinity, Arkansas, Missouri, and Oklahoma.-Continued

[Major drainage boundaries and locations of U.S. Geological Survey (USGS) gaging stations shown in figure 1; calendar year, January 1 through December 31; files listed in table 10 are linked in this table and also included in appendix 2 as a zip archive (the plot_pdf directory of the database) available online at $h t t p: / / p u b s . u s g s . g o v / o f / 2012 / 1026]$

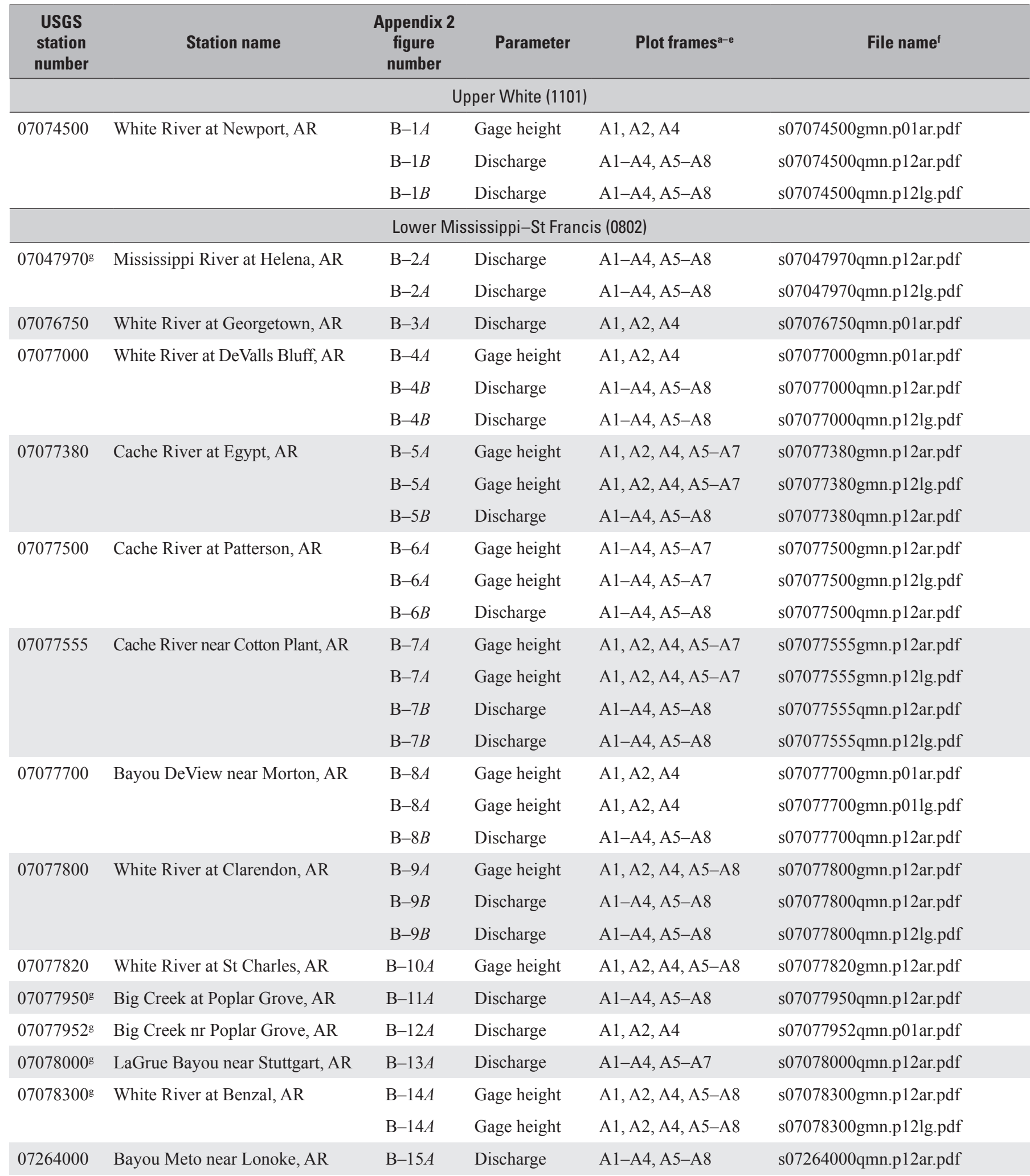


Table 10. Graphical summary files for plots of gage height and discharge data collected at gaging stations in the contributing watersheds of the Cache and White River National Wildlife Refuges and vicinity, Arkansas, Missouri, and Oklahoma.-Continued

[Major drainage boundaries and locations of U.S. Geological Survey (USGS) gaging stations shown in figure 1; calendar year, January 1 through December 31; files listed in table 10 are linked in this table and also included in appendix 2 as a zip archive (the plot_pdf directory of the database) available online at http://pubs.usgs.gov/of/2012/1026]

\begin{tabular}{|c|c|c|c|c|c|}
\hline $\begin{array}{l}\text { USGS } \\
\text { station } \\
\text { number }\end{array}$ & Station name & $\begin{array}{c}\text { Appendix } 2 \\
\text { figure } \\
\text { number }\end{array}$ & Parameter & Plot frames ${ }^{\mathrm{a}-\mathrm{e}}$ & File name ${ }^{f}$ \\
\hline 07263450 & $\begin{array}{l}\text { Arkansas River (Murray Dam) } \\
\text { near Little Rock, AR }\end{array}$ & $\mathrm{B}-16 A$ & Gage height & $\mathrm{A} 1, \mathrm{~A} 2, \mathrm{~A} 4$ & s07263450gmn.p01ar.pdf \\
\hline \multirow[t]{3}{*}{07263500} & Arkansas River at Little Rock, AR & $\mathrm{B}-17 A$ & Gage height & $\mathrm{A} 1, \mathrm{~A} 2, \mathrm{~A} 4$ & s07263500gmn.p01ar.pdf \\
\hline & & B- $-17 A$ & Gage height & $\mathrm{A} 1, \mathrm{~A} 2, \mathrm{~A} 4$ & s07263500gmn.p01lg.pdf \\
\hline & & B- $-17 B$ & Discharge & $\mathrm{A} 1-\mathrm{A} 4, \mathrm{~A} 5-\mathrm{A} 8$ & s07263500qmn.p12ar.pdf \\
\hline \multirow{2}{*}{07265450} & & B- $-18 B$ & Discharge & $\mathrm{A} 1-\mathrm{A} 4, \mathrm{~A} 5-\mathrm{A} 8$ & s07265450qmn.p12ar.pdf \\
\hline & & B- $18 B$ & Discharge & $\mathrm{A} 1-\mathrm{A} 4, \mathrm{~A} 5-\mathrm{A} 8$ & s07265450qmn.p12lg.pdf \\
\hline
\end{tabular}

${ }^{a} \mathrm{~A} 1$, mean-daily values; A2, A3, A4, boxplot interpolation of mean-daily values, annual timestep (A2), decadal timestep (A3), monthly timestep, period-of-record (A4); A5, annual-distribution spread measures; A6, annual-distribution ratio measures; A7, annual distribution, log-coefficient of variation, set of every 5 th percentile of mean-daily values for each complete calendar year, Richards-Baker flashiness index; A8, boxplot interpolation of mean-daily values, daily timestep, period-of-record.

${ }^{\mathrm{b}}$ Percentile spread measures are calculated as the difference between the indicated percentiles divided by the median where $7525=(\mathrm{p} 75-\mathrm{p} 25) / \mathrm{p} 50$, $8020=(\mathrm{p} 80-\mathrm{p} 20) / \mathrm{p} 50$, and $9010=(\mathrm{p} 90-\mathrm{p} 10) / \mathrm{p} 50$.

${ }^{\mathrm{c}}$ Percentile ratio measures are calculated as the ratios of the indicated percentiles where $7525=\mathrm{p} 75 / \mathrm{p} 25,8020=\mathrm{p} 80 / \mathrm{p} 20$, and $9010=\mathrm{p} 90 / \mathrm{p} 10$.

${ }^{\mathrm{d}}$ Richards-Baker flashiness index (Baker and others, 2004).

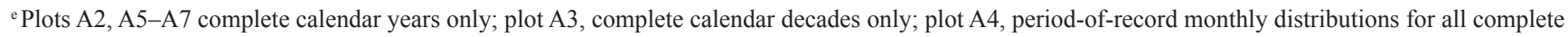
calendar years; plot A8, period-of-record daily distributions for 20 or more complete calendar years.

${ }^{\mathrm{f}}$ File-naming conventions: sSSSSSSSSvar.p[01,12]ps.pdf; SSSSSSS, USGS station identification number; var: gmn, mean-daily gage height, in feet; qmn, mean-daily discharge, in cubic feet per second; p[01,12], p01, plots A1-A4, p12, plots A1-A4, page 1, plots A5-A8, page 2; ps, plot scale: ar, plots A1-A5, vertical axis arithmetic, plots A6-A8, vertical axis base-10 logarithmic; lg, plots A1-A8, base-10 logarithmic.

${ }^{\mathrm{g}}$ Inactive station. 
Table 11. Land-cover percentages for the Cache and White River National Wildlife Refuges contributing watersheds and vicinity, Arkansas, Missouri, and Oklahoma, based on the 1992 National Land Cover Database.

[NWR, National Wildlife Refuge; NLCD, National Land Cover Database; 1992 NLCD (U.S. Geological Survey, 2008f); see figure 6 for map of 1992 land cover, hydrologic-cataloguing-unit names, and hydrologic-subregion names]

\begin{tabular}{|c|c|c|c|c|c|c|c|c|c|c|c|c|c|c|c|c|c|c|}
\hline \multirow{2}{*}{$\begin{array}{l}\text { Hydrologic } \\
\text { cataloging } \\
\text { unit or } \\
\text { subregion } \\
\text { or NWR }\end{array}$} & \multicolumn{18}{|c|}{ Percentage of 1992 NLCD land-cover class ${ }^{a}$} \\
\hline & 11 & 21 & 22 & 23 & 31 & 32 & 33 & 41 & 42 & 43 & 51 & 71 & 81 & 82 & 83 & 85 & 91 & 92 \\
\hline \multicolumn{19}{|c|}{ Lower Mississippi-St Francis (0802) } \\
\hline 08020100 & 21.0 & $<0.1$ & $<0.1$ & $<0.1$ & 1.4 & $<0.1$ & 0.3 & 1.9 & $<0.1$ & 0.7 & 0.0 & 0.0 & 1.3 & 21.4 & 2.0 & 0.6 & 49.3 & 0.1 \\
\hline 08020202 & 1.2 & 0.4 & 0.1 & 0.3 & $<0.1$ & 0.1 & 0.1 & 65.8 & 0.8 & 11.1 & $<0.1$ & 2.4 & 13.5 & 2.8 & 0.1 & 0.5 & 0.7 & 0.1 \\
\hline 08020203 & 1.4 & 0.8 & 0.4 & 0.6 & 0.0 & $<0.1$ & 0.1 & 7.7 & 0.3 & 2.2 & 0.0 & 0.1 & 6.2 & 67.9 & 6.5 & 0.2 & 5.4 & 0.3 \\
\hline 08020204 & 0.7 & 0.7 & 0.4 & 0.6 & $<0.1$ & $<0.1$ & $<0.1$ & 3.0 & 0.2 & 0.7 & 0.0 & 0.1 & 5.7 & 78.3 & 7.0 & 0.3 & 2.1 & 0.1 \\
\hline 08020205 & 0.8 & 0.7 & 0.3 & 0.3 & 0.0 & $<0.1$ & 0.1 & 6.4 & 0.1 & 2.5 & 0.0 & 0.0 & 4.0 & 70.1 & 6.0 & $<0.1$ & 8.6 & $<0.1$ \\
\hline 08020304 & 0.5 & 0.5 & 0.2 & 0.2 & 0.0 & 0.0 & $<0.1$ & 1.8 & 0.2 & 1.2 & 0.0 & 0.0 & 4.2 & 71.9 & 7.0 & $<0.1$ & 12.2 & $<0.1$ \\
\hline 08020401 & 6.7 & 0.1 & 0.1 & 0.1 & 0.6 & 0.0 & 0.1 & 1.6 & 0.1 & 0.7 & 0.0 & 0.0 & 3.6 & 55.9 & 4.1 & 0.2 & 25.8 & 0.1 \\
\hline 08020402 & 4.6 & 2.3 & 0.6 & 0.9 & 0.0 & $<0.1$ & 0.1 & 10.1 & 0.4 & 3.8 & 0.0 & 0.0 & 6.9 & 50.5 & 5.5 & 0.3 & 13.6 & 0.6 \\
\hline \multicolumn{19}{|c|}{ Upper White (1101) } \\
\hline 11010001 & 4.9 & 0.5 & 0.2 & 0.3 & $<0.1$ & $<0.1$ & 0.1 & 46.9 & 7.2 & 8.2 & 0.5 & 0.1 & 28.8 & 1.3 & 0.2 & 0.1 & 0.4 & 0.1 \\
\hline 11010002 & 1.6 & 2.4 & 1.1 & 0.7 & $<0.1$ & $<0.1$ & $<0.1$ & 28.6 & 3.7 & 3.0 & 0.2 & 1.7 & 54.0 & 1.7 & 0.3 & 0.5 & 0.5 & 0.1 \\
\hline 11010003 & 3.8 & 0.5 & 0.2 & 0.3 & $<0.1$ & $<0.1$ & 0.1 & 39.5 & 15.9 & 9.6 & 0.5 & 0.2 & 28.4 & 0.6 & $<0.1$ & 0.2 & 0.2 & 0.1 \\
\hline 11010010 & 0.4 & 0.2 & 0.2 & 0.2 & 0.0 & $<0.1$ & 0.5 & 68.7 & 0.3 & 3.4 & $<0.1$ & $<0.1$ & 24.9 & 1.0 & 0.0 & 0.1 & $<0.1$ & $<0.1$ \\
\hline 11010011 & 0.3 & 0.1 & $<0.1$ & 0.1 & $<0.1$ & $<0.1$ & 0.2 & 59.4 & 3.2 & 7.1 & 0.1 & 0.2 & 28.5 & 0.7 & $<0.1$ & $<0.1$ & 0.1 & $<0.1$ \\
\hline 11010012 & 0.4 & 0.1 & $<0.1$ & 0.1 & $<0.1$ & $<0.1$ & 1.1 & 59.7 & 1.4 & 7.8 & 0.0 & 0.0 & 24.1 & 4.7 & $<0.1$ & $<0.1$ & 0.3 & 0.0 \\
\hline 11010013 & 1.7 & 0.6 & 0.4 & 0.6 & $<0.1$ & 0.0 & $<0.1$ & 13.4 & 0.3 & 2.2 & 0.0 & 0.0 & 6.8 & 61.7 & 2.9 & 0.4 & 8.8 & 0.1 \\
\hline 11010014 & 3.4 & 0.4 & 0.1 & 0.2 & $<0.1$ & $<0.1$ & 0.1 & 48.9 & 7.0 & 18.0 & 0.1 & $<0.1$ & 17.4 & 3.5 & $<0.1$ & 0.1 & 0.8 & 0.1 \\
\hline \multicolumn{19}{|c|}{ Lower Arkansas (1111) } \\
\hline 11110101 & 2.2 & 5.6 & 1.6 & 1.9 & 0.5 & $<0.1$ & 1.1 & 30.9 & 0.7 & 2.1 & 0.6 & 18.3 & 29.4 & 2.6 & 1.5 & 0.2 & 0.3 & 0.2 \\
\hline 11110102 & 4.0 & 1.4 & 0.7 & 1.1 & $<0.1$ & $<0.1$ & 0.4 & 25.8 & 0.9 & 3.9 & 2.6 & 4.7 & 48.3 & 3.0 & 0.6 & 0.6 & 1.7 & 0.5 \\
\hline 11110103 & 2.0 & 1.7 & 0.8 & 0.7 & 0.1 & $<0.1$ & 0.1 & 33.6 & 2.0 & 7.0 & 0.8 & $<0.1$ & 46.5 & 1.6 & 2.1 & 0.5 & 0.3 & 0.1 \\
\hline 11110104 & 5.1 & 0.8 & 0.5 & 0.5 & 0.1 & 0.2 & 0.2 & 44.6 & 2.2 & 8.4 & 0.5 & 0.2 & 31.5 & 3.5 & 0.1 & 0.4 & 1.0 & 0.3 \\
\hline
\end{tabular}


Table 11. Land-cover percentages for the Cache and White River National Wildlife Refuges contributing watersheds and vicinity, Arkansas, Missouri, and Oklahoma, based on the 1992 National Land Cover Database.-Continued

[NWR, National Wildlife Refuge; NLCD, National Land Cover Database; 1992 NLCD (U.S. Geological Survey, 2008f); see figure 6 for map of 1992 land cover, hydrologic-cataloguing-unit names, and hydrologic-subregion names]

\begin{tabular}{|c|c|c|c|c|c|c|c|c|c|c|c|c|c|c|c|c|c|c|}
\hline \multirow{2}{*}{$\begin{array}{l}\text { Hydrologic } \\
\text { cataloging } \\
\text { unit or } \\
\text { subregion } \\
\text { or NWR }\end{array}$} & \multicolumn{18}{|c|}{ Percentage of 1992 NLCD land-cover class ${ }^{a}$} \\
\hline & 11 & 21 & 22 & 23 & 31 & 32 & 33 & 41 & 42 & 43 & 51 & 71 & 81 & 82 & 83 & 85 & 91 & 92 \\
\hline \multicolumn{19}{|c|}{ Lower Arkansas (1111)_Continued } \\
\hline 11110105 & 0.9 & 0.6 & 0.2 & 0.4 & $<0.1$ & 0.2 & 0.6 & 49.0 & 4.7 & 13.5 & $<0.1$ & 0.0 & 28.1 & 0.6 & $<0.1$ & 0.1 & 0.9 & 0.1 \\
\hline 11110202 & 3.6 & 0.3 & 0.1 & 0.2 & $<0.1$ & $<0.1$ & 0.3 & 31.1 & 17.4 & 18.5 & 0.2 & $<0.1$ & 25.4 & 1.7 & 0.1 & 0.1 & 0.6 & 0.5 \\
\hline 11110203 & 3.4 & 0.8 & 0.2 & 0.5 & $<0.1$ & $<0.1$ & 0.5 & 30.3 & 12.9 & 12.6 & $<0.1$ & 0.0 & 28.3 & 8.0 & $<0.1$ & 0.1 & 1.9 & 0.5 \\
\hline 11110204 & 0.7 & 0.1 & $<0.1$ & 0.1 & $<0.1$ & 0.0 & 0.1 & 42.1 & 9.4 & 20.1 & 0.0 & 0.0 & 23.5 & 1.7 & 0.0 & $<0.1$ & 2.0 & 0.1 \\
\hline 11110205 & 0.6 & 0.2 & $<0.1$ & 0.1 & $<0.1$ & $<0.1$ & 0.3 & 38.1 & 5.0 & 13.4 & $<0.1$ & 0.0 & 38.3 & 2.0 & $<0.1$ & 0.1 & 1.7 & 0.1 \\
\hline 0802 & 2.6 & 0.7 & 0.3 & 0.4 & 0.1 & 0.0 & 0.1 & 11.3 & 0.5 & 3.2 & 0.0 & 0.2 & 7.2 & 62.8 & 5.3 & 0.2 & 11.3 & 0.2 \\
\hline 1101 & 2.0 & 0.5 & 0.2 & 0.2 & 0.0 & 0.0 & 0.2 & 51.4 & 6.6 & 9.9 & 0.2 & 0.3 & 23.6 & 6.8 & 0.3 & 0.1 & 1.4 & 0.1 \\
\hline 1111 & 2.6 & 1.4 & 0.4 & 0.6 & 0.1 & 0.1 & 0.4 & 34.8 & 7.8 & 12.2 & 0.4 & 1.7 & 27.3 & 3.8 & 0.5 & 0.2 & 1.3 & 0.3 \\
\hline \multicolumn{19}{|c|}{ National Wildlife Refuge } \\
\hline $\begin{array}{l}\text { Cache } \\
\text { River }\end{array}$ & 2.7 & $<0.1$ & 0.0 & 0.2 & 0.0 & 0.0 & $<0.1$ & 0.4 & $<0.1$ & 0.3 & 0.0 & 0.0 & 1.6 & 43.6 & 1.2 & $<0.1$ & 49.8 & 0.3 \\
\hline $\begin{array}{l}\text { White } \\
\text { River }\end{array}$ & 7.6 & $<0.1$ & 0.0 & $<0.1$ & $<0.1$ & 0.0 & 0.1 & 1.1 & 0.2 & 0.8 & 0.0 & 0.0 & 0.4 & 2.0 & 0.2 & 0.1 & 87.0 & 0.5 \\
\hline
\end{tabular}

a1992 NLCD class definitions:

11 , open water

21 , low-intensity residential

22 , high-intensity residential

23, commercial/industrial.transportation

31 , bare rock/sand/clay

32, quarries/strip mines/gravel pits

33 , transitional

41 , deciduous forest

42 , evergreen forest

43 , mixed forest

51 , shrubland

71 , grasslands/herbaceous

81 , pasture/hay

82, row crops

83 , small grains

85 , urban/recreational grasses

91 , woody wetlands

92, emergent herbaceous wetlands 
Table 12. Land-cover percentages for the Cache and White River National Wildlife Refuges contributing watersheds and vicinity, Arkansas, Missouri, and Oklahoma, based on the 2001 National Land Cover Database.

[NWR, National Wildlife Refuge; NLCD, National Land Cover Database; 2001 NLCD (Multi-Resolution Land Characteristics Consortium (MRLC), 2011a); see figure 7 for map of 2001 land cover, hydrologic-cataloguing-uinit names, and hydrologic subregion names]

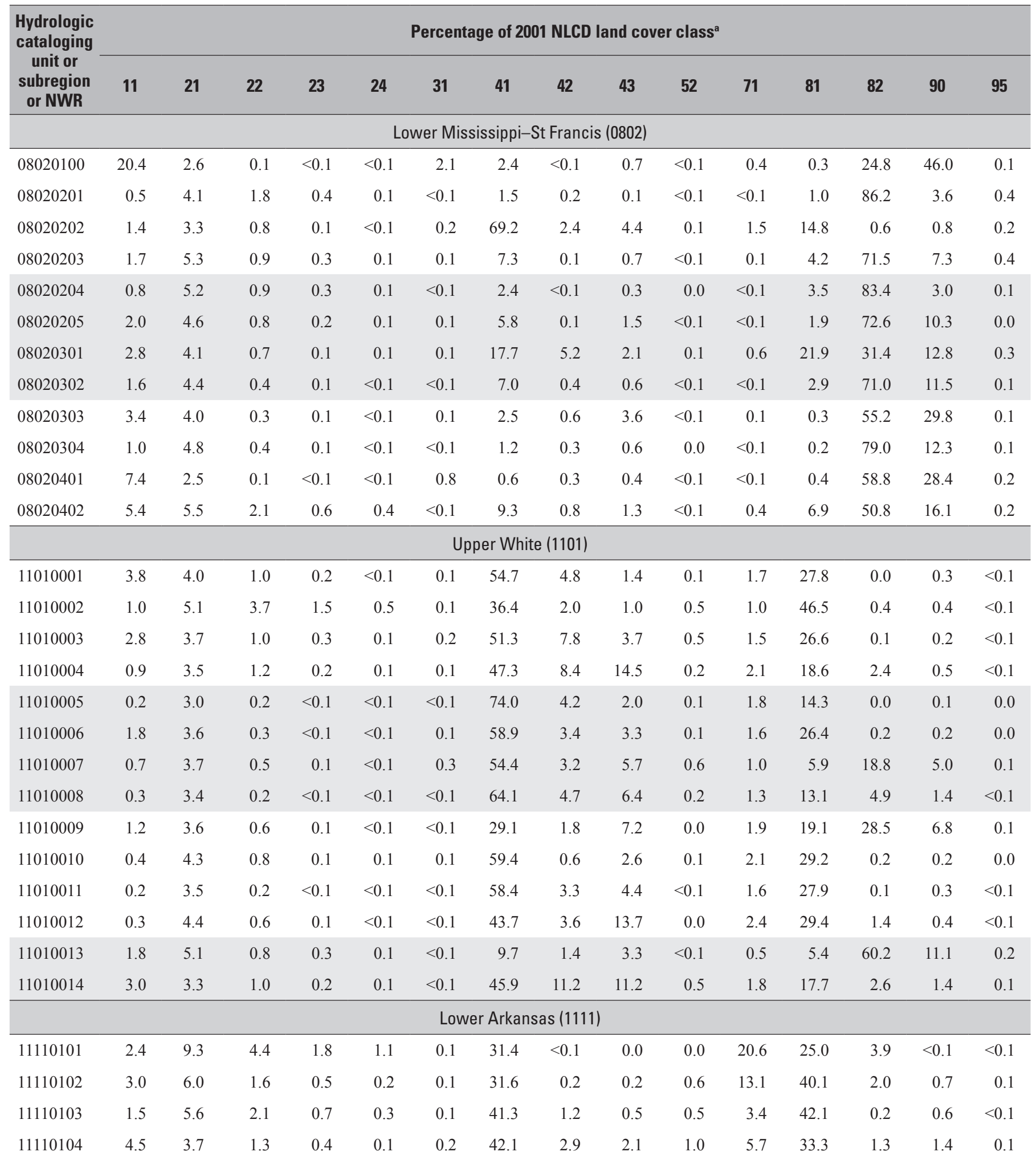


Table 12. Land-cover percentages for the Cache and White River National Wildlife Refuges contributing watersheds and vicinity, Arkansas, Missouri, and Oklahoma, based on the 2001 National Land Cover Database.-Continued

[NWR, National Wildlife Refuge; NLCD, National Land Cover Database; 2001 NLCD (Multi-Resolution Land Characteristics Consortium (MRLC), 2011a); see figure 7 for map of 2001 land cover, hydrologic-cataloguing-uinit names, and hydrologic subregion names]

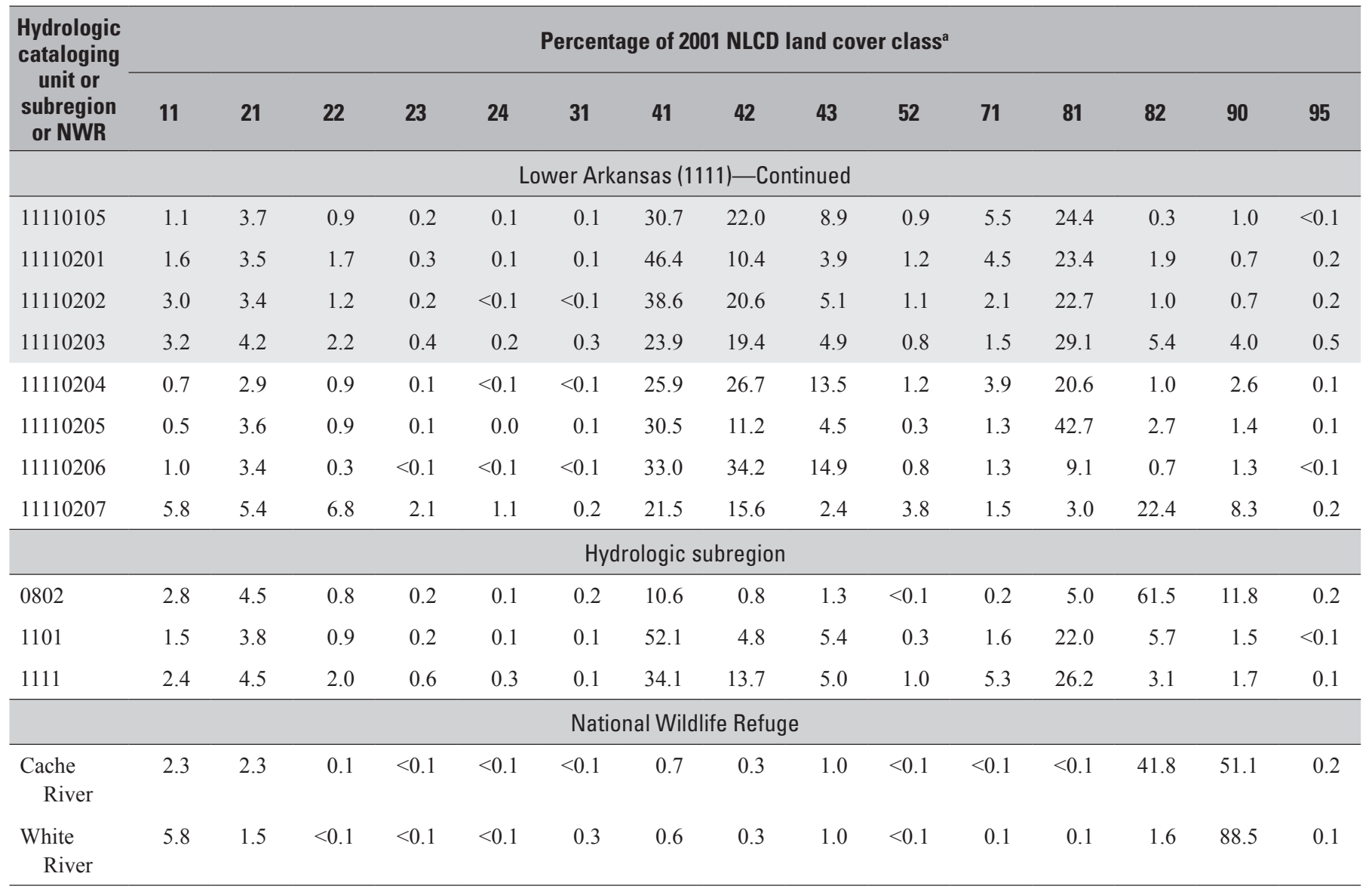

a2001 NLCD class definitions:

11 , open water

21, developed, open space

22 , developed, low intensity

23 , developed, medium intensity

24, developed, high intensity

31 , bare land (rock/sand/clay)

41 , deciduous forest

42 , evergreen forest

43 , mixed forest

52 , shrub/scrub

71 , grasslands/herbaceous

81 , pasture/hay

82 , cultivated crops

90 , woody wetlands

95, emergent herbaceous wetlands 
Table 13. Land-cover-change percentages for the Cache and White River National Wildlife Refuges contributing watersheds and vicinity, Arkansas, Missouri, and Oklahoma, from 1992 to 2001, based on the 1992-2001 National Land Cover Database-Land Cover Change Retrofit product.

[NWR, National Wildlife Refuge; HUC, hydrologic-unit code; NLCD-LCCR, National Land Cover Database-Land Cover Change Retrofit product; 1992-2001 NLCD-LCCR (Fry and others, 2008; Multi-Resolution Land Characteristics Consortium [MRLC], 2011b); positive percent-net-change values indicate a net gain, negative percent-net-change values indicate a net loss; see figure 8 for map of 1992-2001 land-cover change, hydrologic-accounting-unit names, and hydrologic subregion names]

\begin{tabular}{|c|c|c|c|c|c|c|c|c|c|c|c|c|c|c|c|}
\hline \multirow{2}{*}{$\begin{array}{l}\text { Hydrologic } \\
\text { cataloging } \\
\text { unit or } \\
\text { subregion } \\
\text { or NWR }\end{array}$} & \multirow{2}{*}{$\begin{array}{l}\text { Percent of } \\
\text { HUC/NWR } \\
\text { with } \\
\text { classification }^{\text {change }} \\
\text { chan }^{\text {a }}\end{array}$} & \multicolumn{7}{|c|}{$\begin{array}{l}\text { Percent of total HUC area changed in } \\
\text { modified Anderson level } 1 \text { classifications, 2001 b,c }\end{array}$} & \multicolumn{7}{|c|}{$\begin{array}{l}\text { Percent net change from } 1992 \text { to } 2001 \text { in } \\
\text { modified Anderson level } 1 \text { classifications }{ }^{b, d}\end{array}$} \\
\hline & & 1 & 2 & 3 & 4 & 5 & 6 & 7 & 1 & 2 & 3 & 4 & 5 & 6 & 7 \\
\hline \multicolumn{16}{|c|}{ Lower Mississippi-St Francis (0802) } \\
\hline 08020100 & 5.0 & 57.1 & 2.2 & 5.9 & 2.0 & 0.9 & 13.2 & 18.7 & 47.5 & 2.2 & -15.3 & 2.0 & 0.9 & -33.1 & -4.1 \\
\hline 08020202 & 1.9 & 1.6 & 6.6 & 1.2 & 4.9 & 7.0 & 77.4 & 1.4 & 0.5 & 6.6 & 1.2 & -87.8 & 7.0 & 71.2 & 1.3 \\
\hline 08020203 & 1.2 & 27.6 & 10.7 & 1.6 & 9.6 & 0.9 & 37.8 & 11.8 & 19.2 & 10.7 & 1.5 & 4.9 & 0.9 & -3.0 & -34.2 \\
\hline 08020204 & 0.4 & 34.9 & 9.4 & 0.6 & 7.9 & 0.1 & 35.1 & 11.9 & 23.1 & 9.3 & 0.6 & -2.3 & 0.1 & 1.5 & -32.3 \\
\hline 08020205 & 1.4 & 30.4 & 5.8 & 1.6 & 18.8 & 0.1 & 30.5 & 12.8 & 25.0 & 5.8 & 1.6 & 18.7 & 0.1 & -20.5 & -30.6 \\
\hline 08020304 & 1.4 & 20.4 & 5.0 & 0.4 & 15.1 & 0.0 & 31.0 & 28.2 & 11.9 & 5.0 & -0.1 & 15.1 & 0 & -26.9 & -5.1 \\
\hline 08020401 & 2.9 & 38.4 & 2.3 & 13.5 & 4.0 & 0.2 & 18.5 & 23.2 & 15.6 & 2.3 & 13.5 & 3.9 & 0.2 & -23.3 & -12.2 \\
\hline 08020402 & 2.5 & 38.3 & 9.3 & 0.4 & 7.8 & 0.4 & 35.1 & 8.8 & 16.0 & 9.3 & 0.4 & -4.5 & 0.4 & -4.5 & -17.1 \\
\hline \multicolumn{16}{|c|}{ Upper White (1101) } \\
\hline 11010001 & 2.8 & 0.6 & 5.8 & 1.7 & 32.8 & 7.4 & 51.1 & 0.7 & 0.6 & 5.8 & 1.7 & -29.2 & 7.4 & 13.1 & 0.7 \\
\hline 11010002 & 4.0 & 0.4 & 30.3 & 0.7 & 40.8 & 2.4 & 24.5 & 0.8 & 0.4 & 30.3 & 0.7 & 6.0 & 2.4 & -40.7 & 0.8 \\
\hline 11010003 & 3.4 & 0.9 & 7.4 & 1.6 & 31.0 & 6.1 & 52.2 & 0.8 & 0.8 & 7.4 & 1.6 & -33.3 & 6.1 & 16.6 & 0.8 \\
\hline 11010004 & 2.5 & 1.0 & 7.1 & 0.7 & 2.8 & 16.0 & 71.7 & 0.6 & 0.4 & 7.1 & 0.7 & -91.0 & 16.0 & 66.5 & 0.3 \\
\hline 11010010 & 3.5 & 0.4 & 4.6 & 0.5 & 1.7 & 6.2 & 86.5 & 0.1 & 0.1 & 4.6 & 0.5 & -96.1 & 6.2 & 84.5 & 0.1 \\
\hline 11010011 & 3.2 & 0.2 & 5.8 & 0.3 & 3.1 & 5.2 & 85.2 & 0.1 & 0 & 5.8 & 0.3 & -92.4 & 5.2 & 80.9 & 0.1 \\
\hline 11010012 & 3.0 & 0.7 & 3.3 & 0.5 & 2.6 & 6.7 & 85.8 & 0.4 & 0.5 & 3.3 & 0.5 & -93.6 & 6.7 & 82.1 & 0.4 \\
\hline 11010013 & 2.2 & 3.7 & 7.3 & 0.8 & 13.4 & 3.4 & 56.2 & 15.3 & -35.8 & 7.2 & 0.8 & -14.6 & 3.4 & 33.7 & 5.4 \\
\hline 11010014 & 3.0 & 1.0 & 4.1 & 0.4 & 15.8 & 17.9 & 59.8 & 1.0 & $>-0.1$ & 4.1 & 0.4 & -65.9 & 17.9 & 42.7 & 0.9 \\
\hline \multicolumn{16}{|c|}{ Lower Arkansas (1111) } \\
\hline 11110101 & 3.2 & 18.8 & 38.7 & 0.8 & 3.6 & 26.3 & 11.6 & 0.3 & 18.0 & 38.7 & 0.2 & -52.8 & 12.0 & -16.4 & 0.3 \\
\hline 11110102 & 0.9 & 8.8 & 11.8 & 1.4 & 7.4 & 27.4 & 35.6 & 7.5 & 6.0 & 11.8 & -10.5 & -53.4 & 27.1 & 11.5 & 7.5 \\
\hline 11110103 & 2.3 & 1.3 & 25.3 & 2.5 & 2.1 & 16.7 & 51.3 & 0.7 & 1.1 & 25.3 & 1.9 & -72.1 & 16.7 & 26.3 & 0.7 \\
\hline 11110104 & 2.0 & 4.6 & 8.9 & 3.6 & 6.0 & 31.9 & 42.7 & 2.3 & 4.2 & 8.9 & 1.2 & -72.9 & 29.2 & 27.1 & 2.3 \\
\hline
\end{tabular}


Table 13. Land-cover-change percentages for the Cache and White River National Wildlife Refuges contributing watersheds and vicinity, Arkansas, Missouri, and Oklahoma, from 1992 to 2001, based on the 1992-2001 National Land Cover Database-Land Cover Change Retrofit product.-Continued

[NWR, National Wildlife Refuge; HUC, hydrologic-unit code; NLCD-LCCR, National Land Cover Database-Land Cover Change Retrofit product; 1992-2001 NLCD-LCCR (Fry and others, 2008; Multi-Resolution Land Characteristics Consortium [MRLC], 2011b); positive percent-net-change values indicate a net gain, negative percent-net-change values indicate a net loss; see figure 8 for map of 1992-2001 land-cover change, hydrologic-accounting-unit names, and hydrologic subregion names]

\begin{tabular}{|c|c|c|c|c|c|c|c|c|c|c|c|c|c|c|c|}
\hline \multirow{2}{*}{$\begin{array}{l}\text { Hydrologic } \\
\text { cataloging } \\
\text { unit or } \\
\text { subregion } \\
\text { or NWR }\end{array}$} & \multirow{2}{*}{$\begin{array}{l}\text { Percent of } \\
\text { HUC/NWR } \\
\text { with } \\
\text { classification } \\
\text { change }^{\text {a }}\end{array}$} & \multicolumn{7}{|c|}{$\begin{array}{l}\text { Percent of total HUC area changed in } \\
\text { modified Anderson level } 1 \text { classifications, 2001 b,c }\end{array}$} & \multicolumn{7}{|c|}{$\begin{array}{l}\text { Percent net change from } 1992 \text { to } 2001 \text { in } \\
\text { modified Anderson level } 1 \text { classifications }{ }^{b, d}\end{array}$} \\
\hline & & 1 & 2 & 3 & 4 & 5 & 6 & 7 & 1 & 2 & 3 & 4 & 5 & 6 & 7 \\
\hline \multicolumn{16}{|c|}{ Lower Arkansas (1111)_Continued } \\
\hline 11110105 & 2.5 & 7.4 & 6.6 & 2.6 & 12.9 & 32.6 & 36.6 & 1.2 & 6.9 & 5.6 & -0.2 & -59.0 & 22.3 & 23.1 & 1.2 \\
\hline 11110202 & 3.2 & 2.1 & 5.5 & 0.7 & 8.8 & 20.3 & 59.7 & 2.8 & 1.1 & 5.5 & 0.7 & -78.9 & 20.3 & 48.5 & 2.8 \\
\hline 11110203 & 4.6 & 1.3 & 7.3 & 1.4 & 14.5 & 9.6 & 57.7 & 8.2 & -6.1 & 7.3 & 1.4 & -59.0 & 9.6 & 38.6 & 8.2 \\
\hline 11110204 & 1.9 & 1.6 & 2.9 & 0.7 & 12.8 & 39.7 & 40.2 & 2.1 & 1.0 & 2.9 & 0.7 & -72.1 & 39.6 & 25.9 & 2.1 \\
\hline 11110205 & 3.2 & 1.1 & 4.0 & 0.7 & 22.5 & 5.6 & 64.6 & 1.6 & -3.4 & 4.0 & 0.7 & -48.2 & 5.6 & 39.7 & 1.6 \\
\hline 0802 & 1.7 & 27.6 & 6.1 & 2.8 & 15.0 & 1.0 & 33.7 & 13.8 & 14.9 & 6.1 & 0.5 & 1.2 & 1.0 & -9.5 & -14.2 \\
\hline 1101 & 2.7 & 1.0 & 8.0 & 1.0 & 17.8 & 7.9 & 62.9 & 1.5 & -2.1 & 8.0 & 1.0 & -55.9 & 7.9 & 40.4 & 0.8 \\
\hline 1111 & 2.5 & 4.9 & 12.7 & 1.6 & 10.1 & 23.1 & 44.7 & 3.0 & 2.5 & 12.6 & 0.7 & -64.9 & 20.0 & 26.5 & 2.5 \\
\hline \multicolumn{16}{|c|}{ National Wildlife Refuge } \\
\hline $\begin{array}{l}\text { Cache } \\
\text { River }\end{array}$ & 2.5 & 19.2 & 8.7 & 0.9 & 16.4 & 0.0 & 7.1 & 47.7 & 6.7 & 8.7 & 0.9 & 16.4 & 0 & -63.9 & 31.2 \\
\hline $\begin{array}{l}\text { White } \\
\text { River }\end{array}$ & 1.6 & 32.0 & 4.2 & 12.5 & 13.0 & 1.2 & 1.4 & 35.6 & 8.4 & 4.2 & 12.5 & 13.0 & 1.2 & -49.1 & 9.8 \\
\hline
\end{tabular}

${ }^{a}$ Areal percentage of 30-meter cells that were reclassified between 1992 and 2001 using methods described in Fry and others (2008). The reclassified area is used as the base for comparison in presenting the modified Anderson Level 1 classification and net-change percentages for 2001.

${ }^{\mathrm{b}}$ Classifications modified from Anderson level 1 land-cover classifications (Anderson and others, 1976):
1, water
2, urban
3 , barren
4 , forest
5 , grassland
6 , agriculture
7 , wetland

${ }^{c}$ Percentages given are of the portion of the HUC/NWR that changed classification between 1992 and 2001.

${ }^{\mathrm{d}}$ The interpretation would be a conversion from the classification(s) with negative values to the classification(s) with positive values. For example, in the 5 percent of HUC 08020100 that changed classification between 1992 and 2001, primarily barren land and agricultural land were converted to open water. Note that the net gains in modified Anderson level 1 classification balance the net losses; however, the net gains/losses do not necessarily add to 100 percent. 

Appendixes 1-3 


\section{Appendix 1. USGS Annual-Data-Report Manuscripts for Gaging Stations}

USGS annual-data-report manuscripts for selected gaging stations in the contributing watersheds of the Cache and White River NWRs are included in this appendix as downloadable Adobe PDF files (the adr_pdf directory of the database) available online at http://pubs.usgs.gov/of/2012/1026. These reports became available in digital form in 2006 and contain the data tables and summary plots for all continuous-record data collected in a water year at a USGS gaging station (for example, daily-values for gage height, discharge, and, at some stations, water-quality parameters such as water temperature, dissolved oxygen, specific conductance, $\mathrm{pH}$, and turbidity). The reports also contain tables of any periodic data collected at the gaging station, including field measurements and water-quality, sediment, radiological, and biological analyses.

\section{Appendix 2. Hydrograph and Statistical-Summary Plots of Gage Height and Discharge}

Plots of gage height and discharge data collected at the gaging stations listed in tables $2 A-B$ are included in this appendix as downloadable Adobe PDF files (the plot pdf directory of the database) available online at http://pubs.usgs.gov/of/2012/1026. Plot files are listed and referenced in table 10. An explanation file that documents the terminology, symbols, and abbreviations used in the plots is also included in the plots_pdf directory. 


\section{Appendix 3. Hydroecological and Environmental Flow Characterization}

Hydroecological and environmental flow characterization is conceptually different from the application of historically common water-use criteria to pollution abatement and human water needs. Water-discharge and water-withdrawal permits primarily are based on minimumflow requirements developed to provide sufficient dilution of pollutants and(or) sufficient water for downstream water uses (engineering perspective). Hydroecological and environmentalflow criteria are, however, developed to describe the flow regime that would be required to maintain the aquatic and riparian ecosystem of a river reach (ecological perspective). Although the engineering and ecological approaches to water-use regulation typically are applied independently of each other, it is possible to (1) apply each approach within the context of the other or (2) develop a hybrid approach that could accommodate both sets of needs.

\section{Background and Development of Ecological Flow Methodologies}

The development and implementation of instream-flow methodologies for assessing the ecological requirements of riverine aquatic biota began during the late 1960s and early 1970s (U.S. Geological Survey, 2008b). An initial emphasis was placed on determining minimumflow requirements for specific stream reaches and target biota. However, this worst-case scenario specified a minimum flow reserved for instream biological communities, but did not accommodate the full range of ecological-flow needs. Since then, a more comprehensive set of requirements has been developed to include temporal and seasonal flow components that accommodate species-specific ecological niches defined by the intersection of physical habitat requirements, water-quality constraints, and transport of sediment, nutrients, and organic matter (Gillilan and Brown, 1997; Smith, 1998; Waddle, 2001; U.S. Geological Survey, 2008c,d; Annear and Dey, 2006; Dey and Annear, 2006). The Instream Flow Incremental Methodology (IFIM) was developed during the late 1970 s and early 1980 s as an iterative decision-making process designed to help resource managers evaluate the potential effects of a range of hydrologic scenarios on the availability and quality of aquatic and riparian habitat (Bovee, 1982; Bovee and others, 1998; U.S. Geological Survey, 2008b,c). The IFIM emphasizes development of discharge-habitat response functions that quantify the effects of incremental changes in discharge on habitat availability. The Physical Habitat Simulation (PHABSIM) model was developed in concert with and as a major component of the IFIM to predict useable habitat area as a function of discharge (U.S. Geological Survey, 2008c,d; Milhous and others, 1989; Waddle, T.J., ed., 2001). The IFIM-PHABSIM approach focuses on reach-scale stream segments to answer specific questions about water availability for target biota within a sharedresource multiple-use framework.

Within the larger watershed context, a number of statistical approaches have been developed to place the requisite aquatic and riparian habitats within a hydrologic framework using a wide variety of hydrologic metrics deemed ecologically relevant (Richter and others, 1996; Olden and Poff, 2003; Henriksen and others, 2006; U.S. Geological Survey, 2008e,f). Characterization of baseline hydrologic conditions (U.S. Geological Survey, 2008b) and hydrologic reference conditions for different ecogeographic settings (Poff, 1996) are essential prerequisites for instream-flow assessments in order for selected hydrologic metrics to be related to ecological function and critical habitat. Richter and others (1996) proposed a method for assessing the degree of hydrologic alteration related to ecosystem-level human influence - the Indicators of Hydrologic Alteration (IHA). The IHA initially involved 32 hydrologic parameters organized into five ecologically-relevant groups to statistically characterize hydrologic variation. The IHA method presently includes 67 parameters - 33 IHA parameters and 34 Environmental Flow Component (EFC) parameters (The Nature Conservancy, 2007, 2009). The IHA parameters and the EFC parameters are each organized into five groups that define the magnitude, frequency, 
duration, timing, and rate-of-change of ecologically relevant hydrologic events. Olden and Poff (2003) examined 171 hydrologic metrics for redundancy and derived a subset of these measures that retains sufficient explanatory power and relates to ecologically-relevant flow characteristics. This suite of 171 metrics was incorporated in the Hydroecological Integrity Assessment Process (HIP) developed by Henriksen and others (2006) based on research that explored linkages between hydrologic variability and aquatic ecosystem integrity. The HIP was used by Kennen and others (2007) to develop a classification system for New Jersey streams, a set of non-redundant hydrologic indices, and baseline environmental-flow standards. Armstrong and others (2008) used IHA and HIP metrics in a principal-components and hierarchical-cluster analysis to develop a hydrologic classification of $61 \mathrm{New}$ England streams as a baseline for the establishment of environmental-flow criteria for the State of Massachussetts. Falcone and others (2010) constructed a streamgage database designed to aid in the evaluation of natural and altered flow conditions in the conterminous United States. These examples are just a few of many applications of the growing set of instream-flow and statistical-characterization tools and datasets presently available.

\section{Assessment Techniques}

Building on the research discussed in the previous section, three commonly-used standard software packages have been developed: IFIM-PHABSIM (Bovee and others, 1998; Milhous and others, 1989; Waddle, T.J., ed., 2001), IHA (Richter and others, 1996; The Nature Conservancy, 2009), and HIP (Henriksen and others, 2006). Application of these software tools enables the consistent development of instream-flow criteria for specific aquatic environments (IFIM-PHABSIM) and(or) a more general watershed-scale statistical characterization of environmental-flow criteria and the establishment of a hydrologic baseline reference (IHA, HIP). The IHA software was used to generate a subset of the statistics and hydrologic metrics included in the Cache and White River NWRs database.

\section{Instream Flow Incremental Methodology}

The IFIM is a five-phase decision-support system for water-resource managers to use in optimizing water allocation for ecological needs when multiple parties are involved (Bovee and others, 1998; U.S. Geological Survey, 2008b,c). These five phases consist of the following: I, problem identification; II, study planning; III, study implementation; IV, alternatives analysis; and V, problem resolution (U.S. Geological Survey, 2008c). The IFIM allows for spatiotemporal analysis of habitat variability at multiple scales to establish discharge-habitat linkages at each scale. The IFIM can be implemented at three habitat scales: 1, the macrohabitat scale; 2 , the mesohabitat scale; and 3, the microhabitat scale. The macrohabitat scale is stratified at three levels, namely (from largest to smallest), the drainage basin, the drainage network, and the network segment. The network segment is the fundamental habitat-accounting unit in the IFIM (Bovee and others, 1998). Mesohabitats are subsections of macrohabitats that have have common slope, channel shape, and structure; for example, pools, runs, or riffles. Microhabitats are local areas within mesohabitats that have similar depth, velocity, substrate, and cover. Twoway scalability is embedded within the IFIM process; that is, habitat variables can be analyzed at the full range of habitat scales depending on the IFIM study design and questions posed. Habitat can be aggregated from the microhabitat scale to the macrohabitat scale, and conversely, disaggregated from macrohabitats and mesohabitats to individual microhabitats.

\section{Physical Habitat Simulation (Model)}

The connection between discharge and physical habitat for specific life stages of target species is established by using the PHABSIM model (Milhous and others, 1989; Waddle, T.J., ed., 2001; U.S. Geological Survey, 2008c,d) during phase III of the IFIM process. The PHABSIM model simulates hydraulics and microhabitat at the reach scale to establish a 
Weighted Usable Area (WUA) as a function of discharge by integrating velocity, depth, and a channel index (for example, cover and substrate) within the reach. The WUA is expressed as areal units per length of stream and can, therefore, be longitudinally integrated to provide total habitat area at mesohabitat and macrohabitat scales. Monthly and daily habitat-availability time series can be generated by PHABSIM and used as input to IFIM phases IV and V, the analysisof-alternatives and problem-resolution phases. Ideally, instream-flow guidelines can be established that accommodate the ecological needs of the target specie(s) within the constraints of multiple-use demands. This scenario is the intended outcome of an IFIM-PHABSIM study.

\section{Indicators of Hydrologic Alteration}

The IHA software package was developed by Richter and others (1996) and The Nature Conservancy $(2007,2009)$ to provide a tool for calculating the characteristics of natural and altered hydrologic regimes. Any type of daily hydrologic data can be used as input data for the software, typically stream discharge and gage height, but also groundwater levels, water temperature, specific conductance, dissolved oxygen, pH, or turbidity. Kiesling (2003) used IHA to do a pilot evaluation of risk for biological impairment at five stream sites in the Trinity River Basin, Texas, with inference for application statewide. The application of the IHA software is explained in detail in the methods section of this report, as IHA was used to compute many of the statistics in the Cache and White River NWRs database.

\section{Hydroecological Integrity (Assessment) Process}

The HIP is a four-step process for developing a set of hydrologic indices that are streamclass specific and relate to the five major components of the flow regime-magnitude, frequency, duration, timing, and rate of change (Henriksen and others, 2006; Kennen and others, 2007). The HIP involves: (1) hydrologic classification of streams using the 171 hydrologic indices developed by Olden and Poff (2003), (2) statistical reduction of the full suite of hydrologic indices to a set of non-redundant indices for each stream class that relate to the five major flow components, (3) development of an area-specific Stream-Classification Tool (SCT), and (4) development of an area-specific Hydrologic Assessment Tool (HAT). The SCT is used to place streams that have not been classified within the established classification framework. The HAT is used to establish a hydrologic baseline, environmental-flow standards, and an evaluation of the effects of hydrologic modifications.

The HIP contains four software systems that have been developed to facilitate the assessment process: (1) The Hydrologic Index Tool (HIT) calculates the 171 hydrologic indices (Olden and Poff, 2003) using mean-daily and peak-flow discharge records. The program is designed to import these data from the USGS National Water Information System (NWIS; U.S. Geological Survey, 2011a) and NWISWeb (NWISWeb, U.S. Geological Survey, 2011b,c) databases. (2) The National Hydrologic Assessment Tool (NATHAT; U.S. Geological Survey, 2008e) is based on a national hydrologic classification by Poff (1996) using 420 unregulated streams to define six stream classes. (3) The New Jersey Stream Classification Tool (NJSCT; Kennen and others, 2007; U.S. Geological Survey, 2011g) classifies New Jersey streams into one of four classes based on the skewness of the mean-daily flows and frequency of low-flow events measured at 88 streams: $A$, semi-flashy with moderately-low base flow; $B$, stable with high base flow; $C$, moderately stable with moderately-high base flow; and $D$, flashy with low base flow (Kennen and others, 2007). (4) The New Jersey Hydrologic Assessment Tool (NJHAT; Kennen and others, 2007; U.S. Geological Survey, 2011g) is similar in application to NATHAT but with the modification that the hydrologic-index values are calculated with a user-defined range based on either temporal or spatial data. Index ranges based on temporal data are computed for each station using multi-year record with percentiles derived from individual years. Index ranges based on spatial data are computed for all stations within a streamclassification type with percentiles derived from individual station records. Both the NATHAT and NJHAT are used to establish a hydrologic baseline, environmental-flow standards, and an evaluation of hydrologic modifications, both historic and proposed. 
Manuscript approved on December 14, 2011

Edited by Michael Deacon

Layout by Caryl J. Wipperfurth

Science Publishing Network, Raleigh PSC

For more information about this publication, contact: Gary R. Buell USGS Georgia Water Science Center 3039 Amwiler Road

Atlanta, GA 30360

telephone: 770-903-9160

e-mail: grbuell@usgs.gov

http://ga.water.usgs.gov/ 
